\title{
Behoeften van familieleden van intensive care patiënten : een onderzoek naar de behoeften aan informatie, ondersteuning en toegankelijkheid van familieleden
}

Citation for published version (APA):

Kaljouw, M. (1998). Behoeften van familieleden van intensive care patiënten : een onderzoek naar de behoeften aan informatie, ondersteuning en toegankelijkheid van familieleden. [Doctoral Thesis, Maastricht University]. Universiteit Maastricht. https://doi.org/10.26481/dis.19980305mk

Document status and date:

Published: 01/01/1998

DOI:

10.26481/dis.19980305mk

Document Version:

Publisher's PDF, also known as Version of record

Please check the document version of this publication:

- A submitted manuscript is the version of the article upon submission and before peer-review. There can be important differences between the submitted version and the official published version of record. People interested in the research are advised to contact the author for the final version of the publication, or visit the DOI to the publisher's website.

- The final author version and the galley proof are versions of the publication after peer review.

- The final published version features the final layout of the paper including the volume, issue and page numbers.

Link to publication

\footnotetext{
General rights rights.

- You may freely distribute the URL identifying the publication in the public portal. please follow below link for the End User Agreement:

www.umlib.nl/taverne-license

Take down policy

If you believe that this document breaches copyright please contact us at:

repository@maastrichtuniversity.nl

providing details and we will investigate your claim.
}

Copyright and moral rights for the publications made accessible in the public portal are retained by the authors and/or other copyright owners and it is a condition of accessing publications that users recognise and abide by the legal requirements associated with these

- Users may download and print one copy of any publication from the public portal for the purpose of private study or research.

- You may not further distribute the material or use it for any profit-making activity or commercial gain

If the publication is distributed under the terms of Article 25fa of the Dutch Copyright Act, indicated by the "Taverne" license above, 


\section{BEHOEFTEN VAN FAMILIELEDEN VAN INTENSIVE CARE PATIËNTEN}

Een onderzoek naar behoeften aan informatie, ondersteuning en toegankelijkheid van familieleden.

\section{PROEFSCHRIFT}

ter verkrijging van de graad van doctor aan de Universiteit Maastricht, op gezag van de Rector Magnificus, Prof. Dr. A.C. Nieuwenhuijzen Kruseman volgens het besluit van het College van Decanen, in het openbaar te verdedigen op donderdag 5 maart 1998 om 14.00 uur

door 
Promotor:

Co-promotor:

Beoordelingscommissie:
Prof. Dr. H. Philipsen

Dr. R. M. Bal

Prof. Dr. H. Huyer Abu Saad, (voorzitter)

Dr. Y. van der Graaf (Universiteit Utrecht)

Prof. Dr. G.J. Kok

Prof. Dr. F. Nijhuis

Dr. Ir. H.A. van Swieten (St. Antonius Ziekenhuis Nieuwegein)

\section{Kaljouw, Marian}

Behoeften van familieleden van intensive care patiënten

Marian Kaljouw; (ill. door auteur)

Proefschrift Maastricht.-Met lit. opg. -Met samenvatting in het Engels.

ISBN: 90-9011259-6

Trefw.: familieleden / intensive care / behoeften. 


\section{INHOUDSOPGAVE}

$\begin{array}{llr}1 . & \text { Inleiding } & 1 \\ 1.1 & \text { Inleiding } & 1 \\ 1.2 & \text { Probleemstelling } & 2 \\ 1.3 & \text { Doelstelling } & 3 \\ 1.4 & \text { Opbouw van de dissertatie } & 4\end{array}$

2. Behoeften van familieleden op de intensive care, een literatuuroverzicht 7

$\begin{array}{lll}2.1 & \text { Inleiding } & 7\end{array}$

$\begin{array}{lll}2.2 & \text { Het Neuman Systems Model } & 7\end{array}$

2.3 Behoeftecategorieën 15

$\begin{array}{lll}2.4 & \text { Beïvloedende factoren } & 20\end{array}$

$\begin{array}{llll}2.5 & \text { Coping } & \cdots & \ldots\end{array}$

$\begin{array}{lll}2.6 & \text { Samenvatting } & 30\end{array}$

3. Onderzoeksvragen en onderzoeksmodel $\quad 31$

$3.1 \quad$ Inleiding $\quad 31$

3.2 Onderzoeksmodel 31

3.3 Onderzoeksvragen 31

$\begin{array}{lll}3.4 & \text { Behoeftevariabelen } & 34\end{array}$

3.5 Onafhankelijke en overige factoren $\quad 38$

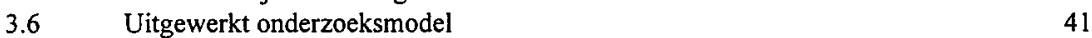

3.7 Definities van begrippen $\quad 42$

$3.8 \quad$ Onderzoeksdesign 43

$\begin{array}{lll}3.9 & \text { Samenvatting } & 44\end{array}$

4. Populatie en methoden 45

4.1 Inleiding 45

4.2 De setting van het onderzoek $\quad 45$

4.3 De onderzoekspopulatie 46

4.4 Respons $\quad 47$

$\begin{array}{lll}4.5 & \text { Methode van onderzoek } & 47\end{array}$

4.6 Het meetinstrument van het hoofdonderzoek 53

$\begin{array}{lll}4.7 & \text { Samenvatting } & 66\end{array}$

$\begin{array}{lll}\text { 5. } & \text { Resultaten I } & 67\end{array}$

Een eerste beschrijving van de resultaten gericht op het

verschil in behoeften van familieleden van hartoperatiepatiënten

en familieleden van overige intensive care patiënten

5.1 Inleiding

Overzicht behoeftecategorieèn

Overzicht sociaal-demografische variabelen

Overzicht intensive care gelieerde variabelen

5.7 Kenmerken van familieleden en invloed op behoeften

$5.8 \quad$ Samenvatting $\quad 78$ 


\section{Resultaten II}

Behoeften van familieleden en factoren die hierop van invloed zijn $\quad 81$

6.2 Behoeften van familieleden aan informatie 81

$\begin{array}{lll}6.3 & \text { Behoeften van familieleden aan ondersteuning } & 87\end{array}$

6.4 Behoeften van familieleden aan toegankelijkheid 93

6.5 Behoeften van familieleden aan begeleiding 98

6.6 Kenmerken van familieleden en invloed op behoeften 103

$\begin{array}{lll}6.7 & \text { Samenvatting } & 111\end{array}$

7. Typologie binnen de behoeften van familieleden 117

$\begin{array}{lll}7.1 & \text { Inleiding } & 117\end{array}$

$\begin{array}{lll}7.2 & \text { Belang van de behoeften } & 120\end{array}$

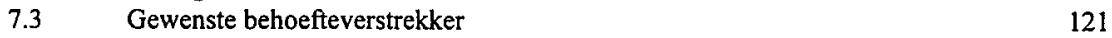

$\begin{array}{llr}7.4 & \text { De feitelijke gang van zaken } & 122\end{array}$

$\begin{array}{lll}7.5 & \text { Typen familieleden op de intensive care } & 123\end{array}$

$\begin{array}{ll}7.6 & 124\end{array}$

$\begin{array}{lll}7.7 & \text { Samenvatting } & 126\end{array}$

$\begin{array}{ll}\text { 8. Typologie en beïnvloedende factoren } & 127\end{array}$

$\begin{array}{lll}8.1 & 127\end{array}$

$\begin{array}{ll}8.2 & 127\end{array}$

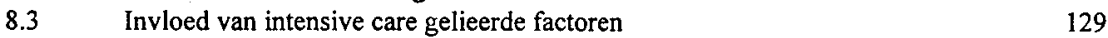

$\begin{array}{ll}\text { 8.4 Invloed van ziektegebonden factoren } & 133\end{array}$

$\begin{array}{ll}8.5 & 135\end{array}$

8.6 Kenmerken van familieleden en typen familieleden $\quad 139$

$\begin{array}{lll}8.7 & \text { Samenvatting } & 140\end{array}$

9. Zorg voor familieleden in de praktijk 143

9.1 Inleiding 143

9.2 Behoeften van familieleden op de intensive care, een vergelijking 143

9.3 De beroepspraktijk op de intensive care 145

9.4 De rol van de verpleegkundige $\quad 146$

$\begin{array}{llr}9.5 & \text { De organisatie } & 148\end{array}$

$\begin{array}{llr}9.6 & \text { Het systeem van zorg voor familieleden } & 149\end{array}$

$\begin{array}{llr}9.7 & \text { Samenvatting } & 152\end{array}$

$\begin{array}{lr}\text { 10. Nabeschouwing } & 155\end{array}$

$\begin{array}{llr}10.1 & \text { Inleiding } & 155\end{array}$

$\begin{array}{ll}10.2 & \text { Theoretische implicaties } \\ 10.3 & 155\end{array}$

$\begin{array}{llr}10.3 & \text { Resultaten } & 156\end{array}$

$\begin{array}{llr}10.4 & \text { Beïnvloedende factoren } & 160\end{array}$

$\begin{array}{lll}10.5 & \text { Praktische implicaties } & 161\end{array}$

$\begin{array}{lll}10.6 & \text { Aanbevelingen voor verder onderzoek } & 163\end{array}$

$\begin{array}{lr}\text { Samenvatting } & 165\end{array}$

$\begin{array}{lr}\text { Summary } & 179\end{array}$

Literatuur

Bijlagen $1 \mathrm{t} / \mathrm{m} 10$

Dankwoord

Curriculum Vitae 


\section{INLEIDING}

\subsection{Inleiding}

Familiebegeleiding op de intensive care verdwijnt vaak naar de achtergrond, ondanks de goede bedoelingen van verpleegkundigen om familieleden te ondersteunen en te begeleiden. De realiteit is dat wensen van familieleden worden genegeerd of vergeten (Daley, 1984). De aandacht gaat, bij opname van een patiënt op de intensive care, vrijwel direct uit naar de patiënt, terwijl familieleden de neiging hebben om zichzelf volledig weg te cijferen.

\section{Aanleiding voor het onderzoek}

De aanleiding voor deze studie is tweeledig. Om te beginnen is deze gelegen in de relatieve verwaarlozing van familieleden van intensive care patiënten. Over het algemeen kan men er van uit gaan dat patiënten die worden opgenomen op de intensive care niet of nauwelijks aanspreekbaar zijn en zich niet bewust zijn van de situatie waarin zij verkeren. Dit in tegenstelling tot hun familieleden, die plotseling geconfronteerd worden met opname van hun naaste op de intensive care en zich van het ene op het andere moment in een situatie van angst, bedreiging en afhankelijkheid bevinden. Gebeurtenissen op de intensive care zijn vaak zo ingrijpend dat familieleden moeite hebben om met de situatie om te gaan. Tot voor kort kon een gebrek aan (onderzoeks-) belangstelling voor zaken als behoeften van familieleden op de intensive care gesignaleerd worden. Een mogelijke oorzaak hiervan zou kunnen zijn dat verpleegkundigen problemen bespreken met familieleden die zij zelf als probleem ervaren en/of signaleren.

Hierbij gaan verpleegkundigen er van uit dat deze gesignaleerde problemen ook door familieleden als problemen ervaren worden. De laatste jaren komt hierin verandering en ontstaat een toenemende interesse voor de samenwerking tussen hulpvrager en hulpverlener. Zo worden bijvoorbeeld patiënten steeds meer betrokken bij zorg- en hulpvragen.

Verpleegplannen worden, met behulp van een verpleegkundige anamnese, door de verpleegkundige in samenspraak met de patiënt opgesteld. Familieleden worden hierbij niet of nauwelijks betrokken. Toch zouden, binnen de verpleegkundige anamnese, ook behoeften van familieleden besproken moeten worden. Op deze wijze kunnen gesignaleerde problemen getoetst worden en worden familieleden in de gelegenheid gesteld wensen en verwachtingen kenbaar te maken. Zo ontstaan mogelijkheden voor verpleegkundige interventies, gericht op familieleden.

De tweede aanleiding is gelegen in de turbulente ontwikkelingen in de gezondheidszorg die de zorg voor patiënt en familieleden (zullen) beïnvloeden. Met steeds verder doorgevoerde bezuinigingsrondes vanuit de overheid enerzijds en hoger gestelde kwaliteitseisen anderzijds wordt de marge waarin de verpleegkundige haar beroep dient uit te oefenen steeds smaller. De wet B.I.G. (Beroepen Individuele Gezondheidszorg, 1994; Sindram, 1993) heeft tot gevolg dat verpleegkundigen verantwoording moeten kunnen afleggen over de wijze waarop de zorg voor patiënten en familieleden is uitgevoerd. 
De Kwaliteitswet Zorginstellingen (Tweede Kamer, vergaderjaar 1993-1994, van kracht 1996), de W.G.B.O. (Wet op de Geneeskundige Behandelings Overeenkomst, 1995), de Wet Klachtrecht Cliënten Zorgsector (1995) en de Wet Medezeggenschap Cliënten Zorginstellingen (in voorbereiding) dragen er toe bij dat patiënt en familie een steeds kritischer houding richting zorgverlener aannemen. Bovendien staat vanuit een integrale visie op zorg de benadering van de patiënt en zijn omgeving in toenemende mate centraal. Velen zijn van mening dat de, tot voor kort, sterk medisch en/of verpleegtechnisch gerichte zorg uitgebreid moet worden met aandacht voor omgevingsaspecten. Onder invloed van de technische en medische vooruitgang neemt de complexiteit van de verpleegkundige zorg toe en wordt het takenpakket van de verpleegkundige voortdurend veranderd en uitgebreid. Ook intensive care verpleegkundigen worden hier in toenemende mate mee geconfronteerd. In Nederland zijn, voor deze studie, zeer weinig wetenschappelijke studies gepubliceerd waarbij behoeften van familieleden in kaart werden gebracht. Dit tekort aan dergelijke verplegingswetenschappelijke studies naar behoeften van familieleden staat in schril contrast met de veelheid aan studies die over dit onderwerp in de Verenigde Staten van Amerika op dit terrein verricht zijn (Hampe, 1975; Breu en Dracup. 1978; Molter, 1979; Daley, 1984; Bouman, 1984; Mathis, 1984; Chartier \& Coutu-Wakulczyk, 1989; McIvor en Thompson, 1988; Dockter et al., 1988; McHale en Bellinger, 1988; Norheim, 1989; Forrester, 1990; Hickey, 1990; Macey en Bouman, 1991; Price et al. 1991; Leske, 1988, 1991 \& 1992; Freichels, 1991; Murphy et al., 1992; Farrel en Frost, 1992; Kleinpell en Powers, 1992; Henneman et al., 1992; Pender, 1993; Engli en Kirsivali-Farmer, 1993; Foss \& Tenholder, 1993; Warren, 1993; Daly et al., 1994; Dovis-Martin, 1994). Bovengenoemd tekort aan verplegingswetenschappelijk onderzoek dat noodzakelijk is om verpleegkundig beleid, gericht op de zorg voor familieleden, te ontwikkelen is de aanleiding tot het onderhavige onderzoek.

In deze dissertatie wordt verslag uitgebracht van een onderzoek naar behoeften van familieleden op de intensive care. Er wordt gezocht naar invloeden van sociaal-demografische factoren (kenmerken van het familielid), intensive care gelieerde factoren (kenmerken van de intensive care), ziektegebonden factoren (kenmerken van de patiënt) en coping factoren (gedragskenmerken van het familielid) op behoeften van familieleden. Voor de verpleegkundige beroepspraktijk zijn de resultaten van dit onderzoek relevant, vanwege de ondersteunende functie die zij kunnen hebben bij het ontwikkelen van kwaliteitsbeleid en het doorvoeren van veranderingsprocessen.

\title{
1.2 Probleemstelling
}

De probleemstelling van dit onderzoek wordt weergegeven in figuur 1.2 en is als volgt geformuleerd:

\author{
'Welke behoeften hebben familieleden van \\ intensive care patiënten op de intensive care \\ en wat is de invloed van sociaal-demografische-, \\ intensive care gelieerde-, ziektegebonden-en \\ coping factoren op \\ behoeften van familieleden?"
}




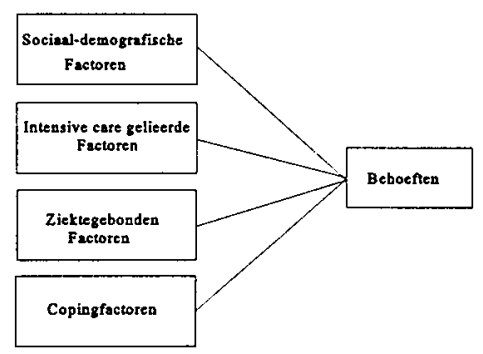

Een invulling van de afzonderlijke concepten en het formuleren van de specifieke vraagstellingen heeft plaatsgevonden aan de hand van een literatuuronderzoek, waarin nadere bestudering verricht is naar:

- onderzoeken naar behoeften van familieleden op de intensive care

- het theoretische kader van waaruit deze probleemstelling behandeld wordt

\subsection{Doelstelling}

Teneinde de probleemstelling te kunnen behandelen is voor een methodische doelstelling gekozen: kunnen de behoeften van familieleden tijdens de intensive care periode van de patiënten worden gemeten met behulp van de C.C.F.N.I. (Critical Care Family Needs Inventory, Molter, 1979), (bijlage 1). De bruikbaarheid van een dergelijk meetinstrument is concreet vertaalbaar in twee afzonderlijke subdoelstellingen waaruit afgeleid kan worden dat de resultaten van het onderzoek, naast de toe te kennen wetenschappelijke waarde, een bijdrage leveren aan de ontwikkeling en de professionalisering van de verpleegkundige beroepsgroep. De twee subdoelstellingen kunnen als volgt worden geformuleerd:

1. Het onderzoek beoogt de toepasbaarheid te achterhalen van de C.C.F.N.I. (Molter, 1979) ten aanzien van de beschrijving van behoeften van familieleden op de intensive care.

2. Tevens wordt beoogd de invloed van eventuele determinanten en effecten te achterhalen vanuit het gezichtspunt of, met behulp van de verkregen resultaten, toekomstig beleid onderbouwd kan worden ten aanzien van begeleiding van familieleden op de intensive care. 
Ter exploratie van de bruikbaarheid van de C.C.F.N.I. (Molter, 1979) is een aantal stappen noodzakelijk:

1. Vertaling van de C.C.F.N.I. (Molter, 1979) en aanpassing aan de Nederlandse situatie.

2. Vaststelling van eventuele determinanten en effecten.

3. Bestudering van relaties tussen de verschillende onderzoeksvariabelen geponeerd in het onderzoeksmodel van de huidige studie en geconcretiseerd in de afzonderlijke deelvraagstellingen.

\subsection{Opbouw van de dissertatie}

Naast de inleiding bestaat de dissertatie uit negen hoofdstukken. Hoofdstuk 2 geeft een nadere bestudering weer van de onderzoeken die gedaan zijn naar behoeften van familieleden op de intensive care, waarbij de Neuman Systeem Theorie (Neuman, 1995) als theoretische basis dient. Uitgaande van Neuman's Systems Theorie (Neuman, 1995) richt deze studie zich op secundaire verpleegkundige interventies ten behoeve van familieleden op de intensive care. Behoeften van familieleden worden zowel algemeen als specifiek benaderd. Omdat veel onderzoekers behoeften van familieleden op behoefte-item niveau hebben onderzocht en slechts enkelen behoefte-items ondergebracht hebben in behoeftecategorieën, richt deze studie zich op behoeften van familieleden aan informatie, ondersteuning en toegankelijkheid (specifieke behoeftecategorieën) en op behoeften van familieleden in het algemeen (algemene behoeftecategorie "behoeften aan begeleiding").

Hoofdstuk 3 beschrijft de onderzoeksvragen en het onderzoeksmodel. Het onderzoek kent twee centrale vraagstellingen, te weten 1: "Welke behoeften aan begeleiding ervaren familieleden op de intensive care?" en 2: "Wat is de invloed van eventuele determinanten en effecten op deze behoeften?". Beide vraagstellingen zijn onderverdeeld in deelvraagstellingen. De eerste centrale onderzoeksvraag wordt onderverdeeld in vragen naar behoeften aan informatie, ondersteuning en toegankelijkheid. Hierbij wordt zowel gekeken naar de gewenste behoefteverstrekker, de vraag of in de behoeften is voorzien en de vraag wie in de behoeften heeft voorzien.

De tweede centrale onderzoeksvraag wordt onderverdeeld in vragen naar invloed van sociaaldemografische factoren, intensive care gelieerde factoren, ziektegebonden factoren en coping factoren. Hier wordt invloed verondersteld van deze factoren op de keuze van familieleden voor de gewenste behoefteverstrekker. Het hoofdstuk wordt afgesloten met een uitgewerkt onderzoeksmodel.

In hoofdstuk 4 worden de onderzoekspopulatie, de onderzoeksmethoden, de setting van het onderzoek en de respons beschreven. Leidraad is de conclusie dat het onderzoeksmodel, gebaseerd op het theoretisch model van Neuman (Neuman, 1995) een geschikt uitgangspunt vormt voor de concrete invulling van het theoretisch kader van deze studie. 
Omdat deze studie er van uitgaat dat een aantal wijzigingen de bruikbaarheid van het model kunnen vergroten, wordt gekozen voor de toevoeging van nieuwe factoren en uitbreiding van veronderstelde relaties. De keuze voor nieuwe factoren is enerzijds gebaseerd op theoretische overwegingen en anderzijds op de specifieke kenmerken van de intensive care.

Het meetinstrument wordt besproken aan de hand van de variabelen die afzonderlijk worden toegelicht.

Hoofdstuk 5 (resultaten I) is een descriptie van de belangrijkste resultaten gericht op behoeften van familieleden op de intensive care (de eerste centrale onderzoeksvraag). Achtereenvolgens worden de behoeften van familieleden aan informatie, ondersteuning en toegankelijkheid beschreven. Behoeften van familieleden aan begeleiding wordt beschreven als het totaal van behoeften aan informatie, ondersteuning en toegankelijkheid. Tot slot wordt in dit hoofdstuk gekeken naar verschillen in behoeften tussen familieleden van hartoperatiepatiënten en familieleden van overige intensive care patiënten. Nadat achtereenvolgens de behoeften van familieleden per categorie zijn gepresenteerd, worden aan het eind van dit hoofdstuk, twee profielen beschreven.

In hoofdstuk 6 (resultaten II) worden de resultaten met betrekking tot de tweede centrale onderzoeksvraag en de daaruit afgeleide deelvragen gepresenteerd. Achtereenvolgens wordt de invloed van determinanten en effecten op behoeften in het algemeen en behoeften aan informatie, ondersteuning en toegankelijkheid in het bijzonder beschreven. Onderscheid wordt gemaakt tussen de beide onderzoeksgroepen (familieleden van hartoperatiepatiënten en familieleden van overige intensive care patiënten). Tot slot worden profielen, ontwikkeld met behulp van logistische regressie analyse voor de behoeftecategorieën, gepresenteerd.

In de hoofdstukken 7 en 8 worden typen familieleden in relatie tot behoeften gepresenteerd. De basis hiervoor wordt gevormd door de vier subvragen (1: is de behoefte belangrijk 2; wie is de gewenste behoefteverstrekker; 3 ; is er in de gewenste behoeften voorzien en 4; wie heeft in de gewenste behoeften voorzien) waaruit behoefte-items zijn opgebouwd. Op deze wijze wordt een antwoord gegeven op de deelvraagstellingen van eerste centrale onderzoeksvraag (Welke behoeften aan begeleiding hebben familieleden op de intensive care?). In dit hoofdstuk wordt steeds het onderscheid tussen familieleden van hartoperatiepatiënten en familieleden van overige intensive care patiënten weergegeven.

In hoofdstuk 8 wordt een antwoord gegeven op de deelvraagstellingen van de tweede centrale onderzoeksvraag (Wat is de invloed van eventuele determinanten en effecten op behoeften van familieleden?), waarbij specifiek gekeken wordt naar de invloeden op de gewenste behoefteverstrekker. In dit hoofdstuk worden drie typen familieleden gepresenteerd, namelijk type $\mathrm{A}$ (het type familielid dat voorkeur heeft voor de verpleegkundige), type $\mathrm{B}$ (het type familielid dat voorkeur heeft voor een andere discipline) en type $C$ (het type familielid dat geen voorkeur heeft omdat dit type de behoefte niet belangrijk vindt).

In hoofdstuk 9 wordt, door middel van een praktijkgerichte benadering, beschreven wat het belang van de bevindingen uit deze studie voor de beroepspraktijk kan zijn. Eerst wordt nogmaals ingegaan op de behoeften van familieleden op de intensive care, waarbij op behoefte-item niveau de resultaten vergeleken worden met de resultaten uit andere studies. 
Met behulp van de in hoofdstuk 7 en 8 ontwikkelde familie typologie en de in hoofdstuk 6 beschreven beïnvloedende factoren, wordt gekeken naar de specifieke behoeften van familieleden, de beïnvloedende factoren en de gewenste behoefteverstrekker.

Tot slot wordt, in hoofdstuk 9 met behulp van een familie-anamnesegesprek, een voorstel gepresenteerd voor een systeem van zorg voor familieleden gericht op specifieke doelgroepen.

In hoofdstuk 10 volgt een nabeschouwing. Achtereenvolgens worden theoretische implicaties, resultaten en praktische implicaties besproken. 
BEHOEFTEN VAN FAMILIELEDEN VAN INTENSIVE CARE PATIËNTEN 


\section{BEHOEFTEN VAN FAMILIELEDEN OP DE INTENSIVE CARE, EEN LITERATUUROVERZICHT}

\subsection{Inleiding}

Opname van een patiënt op de intensive care is, ook voor familieleden, een ingrijpende gebeurtenis. Verschillende bronnen van stress liggen hieraan ten grondslag. Hierbij moet gedacht worden aan de soms zeer onverwachte opname van de patiënt op de intensive care, de onzekere prognose, twijfel over de toekomst, mogelijkheid van overlijden of blijvende handicap, gebrek aan privacy en onbekendheid met de intensive care. Ook de sociale relaties van familieleden van intensive care patiënten staan, door stressvolle gebeurtenissen onder druk. Familieleden zijn, na opname van de patiënt op de intensive care, afwisselend thuis en in het ziekenhuis. Hierdoor valt de ondersteuning van familieleden, vrienden en/of buren gedeeltelijk weg. Familieleden van intensive care patiënten zijn voor ondersteuning afhankelijk geworden van gezondheidszorgwerkers op de intensive care (Halm, 1990).

In dit hoofdstuk wordt, na een beschrijving van de omvang van de doelgroep, een literatuuroverzicht gegeven, gericht op behoeften van familieleden tijdens de intensive care periode van de patiënt. Het theoretisch fundament voor deze studie wordt enerzijds gevormd door het Neuman Systems Model (Neuman, 1995), anderzijds vormt empirisch materiaal de theoretische basis voor onderhavige studie.

\subsection{Het Neuman Systems Model}

Neuman (1995), besteedt in het Neuman Systems Model (1995) veel aandacht aan de plaats van familieleden in het verpleegkundig domein. Zij benoemt het gezin als "cliëntsysteem". Haar model wordt eveneens toegepast op de behoeften van familieleden op de intensive care (McCormac-Bueno \& Kendall Sengin, 1995). Het Neuman Systems Model (1995) is gebaseerd op verscheidende theorieën, namelijk systeem-theorie, stress-copingtheorie en preventietheorie. Een eerste belangrijke theoretische basis wordt gevormd door de systeemtheorie. Neuman (1995) definieert de mens als een open cliëntsysteem, opgebouwd uit fysiologische-, psychologische-, sociaal-culturele-, ontwikkelings- en spirituele variabelen en in voortdurende interactie met de omgeving. Dit systeem staat in open verbinding met de omgeving en onderhoudt een voortdurende uitwisseling met materie, energie en informatie.

Het cliëntsysteem en zijn omgeving hebben een wederkerige relatie, dat wil zeggen dat beiden elkaar beïnvloeden. Het voortdurende proces van input, output en feedback zorgt er voor dat de interacties tussen het cliëntsysteem en de omgeving circulair van aard zijn.

Een tweede theoretisch fundament voor Neuman's model (1995) is de stress-copingtheorie van Lazarus en Folkman (1984). Stress en het omgaan met stress is een essentieel onderdeel van het Neuman Systems Model (1995). Zij gebruikt met name de stress-copingtheorie om het concept "omgeving" inhoud te geven. Omgeving wordt gedefinieerd als alle interne en externe factoren of invloeden die het cliëntsysteem ongeven. Hiernaast gebruikt Neuman (1995) de stress-copingtheorie om de wijze waarop de uitwisseling tussen het systeem en de omgeving plaatsvindt te verduidelijken. 
Een belangrijke overeenkomst tussen het Neuman Systems Model (Neuman, 1995) en het stresscoping model van Lazarus en Folkman (1984) is, dat beiden uitgaan van de eigen visie van het cliëntsysteem. Lazarus en Folkman (1984) beschrijven dit in het begrip taxatie (appraisal). In het verpleegkundig proces, zoals gehanteerd binnen het Neuman Systems Model (Neuman, 1995), wordt zowel perceptie als eigen ervaring van het cliëntsysteem bij de verpleegkundige diagnostiek, - interventies en - evaluatie betrokken.

Preventie is binnen Neuman Systems Model (Neuman,1995) het fundament van waaruit het verpleegkundig handelen gestalte wordt gegeven. Neuman (1995) verdeelt verpleegkundige interventies onder in drie categorieën (primair preventieve interventies, secundair preventieve interventies en tertiair preventieve interventies). Primair preventieve interventies zijn gericht op het bevorderen van de gezondheid. Deze interventies vinden plaats wanneer stressoren verwacht worden of reeds aanwezig zijn, maar nog geen verstoringen hebben veroorzaakt. Secundair preventieve interventies zijn gericht op het herstellen van de gezondheid en worden uitgevoerd nadat stressoren het evenwicht en daarmee de gezondheid hebben verstoord. Tertiair preventieve interventies zijn volgens Neuman (1995) gericht op het behouden van de gezondheid en vinden plaats tijdens de herstelfase.

Familieleden nemen, in vergelijking met andere verplegingswetenschappelijke modellen, in het Neuman Systems Model (Neuman, 1995) een relatief belangrijke plaats in. Neuman (1995) benadert de mens als een open systeem, waardoor het model niet alleen toegepast kan worden op de mens als individu, maar tevens op grotere systemen, zoals het gezin.

Het cliëntsysteem wordt door Neuman (1995) symbolisch voorgesteld als een centrale kern die door een aantal beschermende cirkels wordt omgeven (figuur

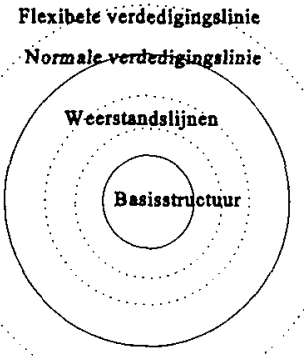
2.2). Bij een gezin als cliëntsysteem bestaat de basisstructuur uit de samenstelling van het gezin en het belang daarvoor voor de verschillende gezinsleden. Deze basisstructuur is van levensbelang en wordt beschermd door de weerstandslijnen. De weerstandslijnen bestaan uit een groot aantal willekeurige of onbewuste factoren die het welbevinden en gezondheid ondersteunen. Bij een gezin als systeem kunnen bepaalde normen en waarden leiden tot weerstandsreacties. De noodzaak tot opname in een ziekenhuis van één van de gezinsleden kan gezien worden als een verstoring van het basissysteem.

De normale verdedigingslinie bestaat uit een patroon van reageren dat over langere tijd is ontwikkeld. Neuman (1995) benoemt dit als de stabiliteit van het cliëntsysteem. Evenals de andere cirkels in figuur $2.2 \mathrm{kan}$ ook deze cirkel worden geanalyseerd aan de hand van de vijf eerder genoemde variabelen (fysiologisch, psychologisch, sociaal-cultureel, ontwikkeling en spiritueel).

Kenmerken van de normale verdedigingslinie bij een gezin als cliëntsysteem zijn bijvoorbeeld de communicatiepatronen, rolpatronen, onderlinge regels, sociaal-cultureel en religieus gedrag. 
Deze normale verdedigingslinie wordt omgeven door de flexibele verdedigingslinie. Door met een zekere flexibiliteit en veerkracht druk op het systeem op te vangen, ontstaat er ais het ware een verzachtende werking waardoor verdere reactie van het systeem uitblijft. $\mathrm{Bij}$ een gezin wordt de flexibele verdedigingslinie onder andere gevormd door de dagelijkse besluitvorming, het gebruik van gezondheidszorg of andere vormen van steun.

\subsubsection{Behoeften van familieleden van intensive care patiënten}

Neuman (1995) richt zich in haar Neuman Systems Model (Neuman, 1995) op de behoefte van familieleden op de intensive care middels een raamwerk (tabel 2.2.1).

De interventies van intensive care verpleegkundigen zijn gericht op primaire, secundaire en tertiaire preventie. De primaire interventies zijn gericht op het behouden van de integriteit van het familiesysteem en het verminderen van stressoren. De secundaire interventies richten zich op het gebruiken en versterken van de bestaande familiestructuur. De tertiaire interventies richten zich op de reconstructie van het cliëntsysteem. Neuman (1995) is van mening dat de zorg voor familieleden steeds meer aandacht zal krijgen binnen de gezondheidszorg. Familieleden willen meer betrokken worden in het nemen van besluiten omtrent de behandelingsmogelijkheden en de keuzes in de zorg. Op de intensive care wordt, ten gevolge van de hoogcomplexe verpleeg-situaties, over het algemeen een patiëntgericht verpleegsysteem (patiëntentoewijzing) gehanteerd, waarbij de verpleegkundige meestal de zorg heeft voor één patiënt. Hierdoor verkeren vooral intensive care verpleegkundigen in de unieke positie om zich te richten op de behoeften van familieleden.

Uitgaande van Neuman's Systems Model (Neuman,1995) richt deze studie zich op secundaire verpleegkundige interventies ten behoeve van behoeften van familieleden op de intensive care.

Zoals uit tabel 2.2.1 valt af te leiden is de secundaire interventiestrategie gericht op "assist family spiritual and psychosocial" een strategie gericht op interventies die benoemd zouden kunnen worden onder "ondersteunende interventies". Ook Molter (1979), Daley (1984) en Leske (1991 \& 1992) beschrijven de behoeftecategorie "needs for support".

"Answer questions honestly, family communication, provide assurance regarding treatments/ prognosis en update family regularly" zijn gericht op "informatieve interventies". Bovengenoemde onderzoekers spreken hier eveneens van "needs for information". Hoewel geen van de onderzoekers behoeften op het gebied van toegankelijkheid daadwerkelijk als zodanig benoemt en categoriseert, valt uit het model van Neuman (1995) af te leiden dat "liberal visitation" en "family involvement in careplanning" als belangrijke voorwaarden gezien kunnen worden om in behoeften te voorzien. 
Tabel 2.2.1 Interventions for the families of critically ill clients

\begin{tabular}{|c|c|c|}
\hline 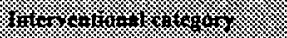 & (174) & (1) \\
\hline \multicolumn{3}{|l|}{ Primary } \\
\hline Intervention as prevention & $\begin{array}{l}\text { Retain family stability } \\
\text { Reduce stressor encounter } \\
\text { Desensitize family to } \\
\text { stressors }\end{array}$ & $\begin{array}{l}\text { Develop family-focused critical care } \\
\text { environment } \\
\text {-Support teamplanning } \\
\text {-Communication systems } \\
\text {-Convenient waiting/phone } \\
\text { - Liberal visitation } \\
\text { Anticipate/plan family needs } \\
\text {-Client data supplement } \\
\text {-Illness/support response } \\
\text { Family and staff education }\end{array}$ \\
\hline \multicolumn{3}{|l|}{ Secundary } \\
\hline Intervention as treatment & $\begin{array}{l}\text { Attain family systems stability } \\
\text { Utilize family's resources }\end{array}$ & $\begin{array}{l}\text { Utilize support teams to assist family } \\
\text { (psychosocial/spiritual) } \\
\text { Establish family communication with } \\
\text { consistent personnel } \\
\text {-Answer questions honestly } \\
\text {-Update family regularly } \\
\text { Support client/family interaction } \\
\text { (liberal visitation) } \\
\text { Establish family involvement in care } \\
\text { planning } \\
\text { Provide assurance regarding treatments/ } \\
\text { prognosis }\end{array}$ \\
\hline \multicolumn{3}{|l|}{ Tertiary } \\
\hline Intervention as reconstitution & $\begin{array}{l}\text { Maintain the family systems } \\
\text { Avoid additional reactions to } \\
\text { stressors }\end{array}$ & $\begin{array}{l}\text { Involve family in ongoing care } \\
\text { Maintain family contact with support teams } \\
\text { Maintain effective communication } \\
\text { Provide education for planned } \\
\text { transfer/discharge }\end{array}$ \\
\hline
\end{tabular}

The Neuman Systems Model (Neuman,1995).

In iedere studie die gedaan is naar behoeften van familieleden op de intensive care wordt gerefereerd aan de dreiging die onmiddellijk ontstaat bij opname van de patiënt op de intensive care (Hampe, 1975; Molter, 1979; McGregor et al., 1981; Yoder \& Jones, 1982; Bozett et al., 1983; Daley, 1984; O'Neill-Norris en Grove, 1986; Mclvor en Thompson, 1988; Dockter et al., 1988; McHale en Bellinger, 1988; Liddle, 1988; Norheim, 1989; Forrester et al.,1990; Chartier \& Coutu-Wakulczyk, 1989; Freichels, 1991; Koller, 1991; Murphy et al., 1992; Farrel en Frost, 1992; Titler \& Walsh, 1992; Henneman et al., 1992; Pender, 1993; Biley et al., 1993; Davis-Martin, 1994).

Over het algemeen kan gesteld worden dat intensive care patiënten niet aanspreekbaar zijn en zich niet of nauwelijks bewust zijn van de situatie waarin zij verkeren. Dit in tegenstelling tot de familieleden, die vaak plotseling geconfronteerd worden met de opname van hun naaste en zich van het ene op het andere moment in een situatie van angst, bedreiging en afhankelijkheid bevinden. 
De aandacht van professionals gaat op die momenten direct uit naar de patiënt, terwijl familieleden de neiging hebben om zichzelf volledig weg te cijferen ten behoeve van een maximale behandeling van hun naaste (Molter, 1979; Daley, 1984).

Ondanks de intentie van verpleegkundigen om de familie te ondersteunen en te begeleiden, is de realiteit dat de wensen van familieleden vaak worden genegeerd of vergeten (Daley, 1984). Factoren als tijd en onvoldoende kennis op het gebied van familiebegeleiding spelen hier een rol (Daley, 1984). De gebeurtenissen op een intensive care zijn vaak zo ingrijpend dat familieleden moeite hebben om met deze situatie om te gaan.

Wanneer familieleden door de intensive care verpleegkundige geïnformeerd worden is het meestal zo dat de besproken problemen door de verpleegkundige als probleem worden ervaren en niet door de familie (Daley, 1984).

In deze studie worden behoeften in het algemeen, op grond van empirisch materiaal (Daley, 1984; Leske, 1988) onderscheiden in (1) de aard van de behoeften en (2) de mate (het belang) van behoeften. - Daley (1984) en Leske (1988) maakten gebruik van Molter's Critical Care Family Needs Inventory, (1979, 46 items) en clusterden de behoefte-items, op grond van de aard van de behoeften, in behoeftecategorieën. - Daley (1984) bracht de 46 behoefte-items onder in 6 categorieën (1) the need for relief of anxiety, (2) the need for information, (3) the need to be be with the patient, (4) the need to be helpful to the patient, (5) the need for support and ventilation en (6) personal needs. - Leske (1988) bracht de 46 behoefte-items onder in 5 categorieën (1) support needs, (2) comfort needs, (3) information needs, (4) proximity needs en (5) assurance needs. Geen van de onderzoekers gaat in op behoeften in het algemeen.

Neuman (1995) beschrijft, eveneens op grond van empirisch materiaal (Hickey, 1990; Henneman et al., 1992; Leske, 1992), een clustering van behoefte-items in categorieën. Deze kunnen echter niet op grond van overeenkomst worden gekenmerkt als steeds terugkerende categorieën waarbij consensus bestaat. De enige behoeftecategorie die bij bovengenoemde onderzoekers overeenkomt is de behoeftecategorie "informatie". Ook Neuman (1995) gaat niet in op behoeften in het algemeen. Wel benoemt ze een aantal behoefte-items die uit het onderzoeksmateriaal als zeer belangrijk naar voren komen (tabel 2.2.1). In tabel 2.2.1.1 wordt een overzicht getoond van de hoogst gescoorde behoefte-items uit de literatuur (Hickey, 1990). Hickey (1990) presenteert een "algemene behoefte-item hiërarchie" uit 8 onderzoeken (Molser, 1979; Rodgers, 1983; Bouman, 1984; Mathis, 1984; Daley, 1984; Leske, 1986; Spatt et al., 1986; O'NeillNorris \& Grove, 1986). Hierin zijn de behoefte-items opgenomen die door familieleden als belangrijk tot zeer belangrijk werden ervaren.

Ook Neuman (1995) ontleent hieraan, in haar theoretisch model, verpleegkundige interventies gericht op informatie (answer questions honestly, update family regularly). 
Tabel 2.2.1.1 Hoogst gescoorde behoefte-items uit de literatuur (Hickey, 1990).

\begin{tabular}{|ll|l|}
\hline \multicolumn{1}{|c|}{ e } & & \\
\hline 8 & $(100 \%)$ & het eerlijk beantwoorden van vragen \\
\hline 8 & $(100 \%)$ & geïnformeerd worden over de diagnose van de patiënt \\
\hline 8 & $(100 \%)$ & geïnformeerd worden over de prognose van de patiënt \\
\hline 7 & $(88 \%)$ & thuis opgebeld worden bij veranderingen m.b.t. de patiënt \\
\hline 7 & $(88 \%)$ & minimaal én keer per dag informatie krijgen \\
\hline 7 & $(88 \%)$ & informatie in begrijpelijke taal krijgen \\
\hline 6 & $(75 \%)$ & het gevoel hebben dat het intensive care personeel betrokken is bij de patiënt \\
\hline 6 & $(75 \%)$ & het gevoel hebben dat er hoop is \\
\hline 5 & $(63 \%)$ & geïnformeerd worden over waarom en wat er bij de patient gebeurt \\
\hline 5 & $(63 \%)$ & de zekerheid hebben dat de best mogelijke zorg wordt verleend \\
\hline 5 & $(63 \%)$ & de patiënt regelmatig kunnen bezoeken \\
\hline 3 & $(38 \%)$ & geïnformeerd worden over de medische behandeling \\
\hline 2 & $(25 \%)$ & geïnformeerd worden door de arts \\
\hline 1 & $(13 \%)$ & $\begin{array}{l}\text { de beschikking hebben over een wachtkamer in de nabije omgeving van de intensive } \\
\text { care }\end{array}$ \\
\hline 1 & $(13 \%)$ & verzekerd worden dat het goed gaat met de patiënt \\
\hline 1 & $(13 \%)$ & een contactpersoon op de intensive care hebben \\
\hline 1 & $(13 \%)$ & iedere dag met een verpleegkundige kunnen spreken \\
\hline 1 & $(13 \%)$ & de aanwezigheid van telefoon in de wachtkamer \\
\hline 1 & $(13 \%)$ & geaccepteerd worden door het intensive care personeel \\
\hline
\end{tabular}

* $\quad$ Frequentie is het aantal keren gescoord in $8(100 \%)$ onderzoeken. Alle behoefte-items werden door familieleden als belangrijk tot zeer belangrijk aangemerkt.

In dit onderzoek wordt uitgegaan van behoeftecategorieën. De keuze voor categorieën is gebaseerd op bevindingen uit empirisch materiaal (Daley, 1984; Leske 1988). Daley (1984) categoriseerde de 46-itemlijst van Molter (1979) in 6 behoeftecategorieën. Leske (1988) categoriseerde dezelfde lijst in 5 behoeftecategorieën (tabel 2.2.1.2). 


\begin{tabular}{|l|l|}
\hline Need to decrease anxiety & Assurance needs \\
Need for information & Information needs \\
Need to be with the patient & Proximity needs \\
Need to be helpful & \\
Need for support and ventilation & Support needs \\
Personal needs & Comfort needs \\
\hline
\end{tabular}

Over het algemeen komen de behoeftecategorieën van Daley (1984) en Leske (1988) overeen, met uitzondering van de categorie "need to be helpful", Daley's 4e behoeftecategorie (tabel 2.2.1.2). Deze behoeftecategorie bestaat uit twee behoefte-items, namelijk (1) "to help with the care of my familymember" en (2) "to have someone tell me how I can help".

Deze behoefte-items zijn door Leske (1988), op grond van onderzoeksresultaten over de periode 1980 - 1988, waarbij 677 familieleden in 14 staten, van de Verenigde Staten, zijn geïnterviewd, ondergebracht in de categorieën "information" en "support".

Op grond van de resultaten van Daley (1984) en Leske (1988) die, naast Molter (1979), gezien mogen worden als de eerste en belangrijkste resultaten uit onderzoek op het gebied van behoeften van familieleden in de Verenigde Staten van Amerika is in deze studie de keuze gemaakt voor behoeftecategorieën.

Om begripsverwarring te voorkomen is vervolgens gekeken naar de aard van de behoeftecategorieën waarbij een onderscheid te maken is tussen instrumenteel gerichte behoeften (information needs), sociaal emotioneel gerichte behoeften (support needs, assurance needs), en op structuur gerichte behoeften (proximity needs, comfort needs).

Behoeften zijn in beginsel, op grond van bovenstaande theoretisering en aard van de behoeften, geclusterd in vier behoeftecategorieën, te weten; "behoeften aan informatie", "behoeften aan ondersteuning", "behoeften aan toegankelijkheid" en "behoeften aan communicatie". De laatste behoeftecategorie bleek empirisch en vooruitlopend op de factoranalyses (hoofdstuk 4) niet goed te onderscheiden van de andere drie behoeftecategorieën. Dit is voornamelijk het geval omdat de behoefte-items uit deze categorie met alle behoeftecategorieën te maken hebben.

Factoranalyse (hoofdstuk 4) resulteert echter in een categorische driedeling van behoeften van familieleden en steunt hierbij de toewijzing van behoeften naar instrumenteel gerichte-, sociaal-emotioneel gerichte- en op structuur gerichte behoeftecategorieën. Op grond van eigen onderzoek (resultaten uit de factoranalyse) enerzijds en empirisch materiaal anderzijds, is besloten on behoeften van familieleden onder te brengen in drie behoeftecategorieën, namelijk (1)“behoeften van aan informatie", (2)“behoeften aan ondersteuning" en (3) "behoeften aan toegankelijkheid". Vanuit enerzijds deze redenatie en anderzijds ten gevolge van het algemene karakter van de behoeftecategorie "communicatie", zijn de behoefte-items uit deze categorie gedeeltelijk toegevoegd aan de eerder genoemde drie behoeftecategorieën (hoofdstuk 4). 
Samen met de drie behoeftecategorieën wordt, eveneens op basis van empirisch materiaal en op basis van de interne consistentie van de gehele behoeftelijst (hoofdstuk 4) een algemene behoeftecategorie "behoeften aan begeleiding" beschouwd. Deze behoeftecategorie wordt in onderhavige studie als "paraplu begrip" gehanteerd waaronder de drie behoeftecategorieën zijn gepositioneerd. Vanuit deze benadering wordt duidelijk dat deze algemene categorie direct betrekking heeft op informatie, ondersteuning en toegankelijkheid. Als zodanig zijn de drie behoeftecategorieën complementair. De vraag "Wat is er met de patiënt aan de hand?" kan worden uitgewerkt binnen de behoeftecategorie "informatie" en de vraag "Hoe word ik opgevangen?" kan worden uitgewerkt binnen de behoeftecategorie "ondersteuning". De vraag naar een bevredigende context kan worden uitgediept binnen de behoeftecategorie "toegankelijkheid".

Ondanks het gegeven dat begeleiding een vaag en algemeen begrip is, gaat het in deze studie om het totaal van activiteiten die familieleden op de intensive care voorzien van informatie, ondersteuning en toegankelijkheid. Juist door de omvang van het totaal, waarbij verondersteld wordt dat het totaal meer is dan de som der delen en daardoor het bereik, wordt deze behoeftecategorie verondersteld van belang te zijn.

Vooruitlopend op de resultaten uit dit onderzoek is het meestal zo dat zowel familieleden als hulpverleners binnen de intensive care veelal over begeleiding in het algemeen spreken in plaats van over specifieke behoeftecategorieën. Ook in de literatuur wordt zowel over behoeftecategorieën (Daley, 1984; Leske, 1988) als over het totaal van de behoefte-items gesproken (Molter, 1979). De laatste benadering, het totaal van de behoefte-items, wordt in de literatuur beschreven als "behoeften van familieleden", zonder dat hieraan een algemene benaming wordt toegekend.

Duidelijk wordt echter dat familieleden op de intensive care willen weten wat er aan de hand is met de patiënt. Zij zullen zich afvragen hoe ze worden opgevangen en wat ze kunnen verwachten. Men wil weten welke situatie zich voordoet en als zodanig zoeken naar een bevredigende context binnen de intensive care. Familieleden willen hun emoties kunnen hanteren en soms delen (Hampe, 1975; Molter, 1979; McGregor et al., 1981; Yoder \& Jones, 1982; Bozett et al., 1983; Daley, 1984; O'Neill-Norris en Grove, 1986; Mclvor en Thompson, 1988; Dockter et al., 1988; McHale en Bellinger, 1988; Liddle, 1988; Norheim, 1989; Forrester et al.,1990; Chartier \& CoutuWakulczyk, 1989; Freichels, 1991; Koller, 1991; Murphy et al., 1992; Farrel en Frost, 1992; Titler \& Walsh, 1992; Henneman et al., 1992; Pender, 1993; Biley et al., 1993; Davis-Martin, 1994; Quinn, et al., 1996; Plowright, 1996; Delva \& Vanoost, 1997; Zazpe et al., 1997;).

Bovenstaande verwachtingen zijn puur menselijke verwachtingen die zich in bijna alle situaties voordoen. Met name in stresserende situaties zoals een opname van een naaste op de intensive care zullen deze verwachtingen direct worden ontwikkeld, immers familieleden komen in een situatie waarin ze niet direct kunnen invullen hoe ze zich moeten gedragen, hoe ze zich moeten voelen, hoe ze moeten denken en hoe ze zich moeten aanpassen (Delva \& Vanoost, 1997). Door middel van de algemene behoeftecategorie "begeleiding" en de daaronder gepositioneerde categorieën "informatie", "ondersteuning" en "toegankelijkheid", wordt verondersteld dat duidelijkheid verkregen kan worden inzake verwachtingen en behoeften van familieleden op de intensive care. 


\subsection{Behoeftecategorieën}

In de volgende paragrafen worden achtereenvolgens de behoeftecategorieën "informatie", "ondersteuning" en "toegankelijkheid" beschreven.

\subsubsection{Behoeften aan informatie}

Informatie is een diffuus begrip dat veel van situatie tot situatie verschillende facetten kent. In deze studie gaat het om het geheel aan min of meer overwogen activiteiten die mensen op de hoogte brengen en houden van een bijzondere situatie. Familieleden op de intensive care vinden behoeften op het gebied van informatie belangrijk (Hampe, 1975; Breu en Dracup, 1978; Molter, 1979; Daley, 1984; Bouman, 1984; Mathis, 1984; Chartier \& Coutu-Wakulczyk, 1989; Mclvor en Thompson, 1988; Dockter et al., 1988; McHale en Bellinger, 1988; Norheim, 1989; Forrester et al., 1990; Hickey, 1990; Macey en Bouman, 1991; Price et al. 1991; Leske, 1991 \& 1992; Freichels, 1991; Murphy et al., 1992; Farrel en Frost, 1992; Kleinpell en Powers, 1992; Henneman et al., 1992; Pender, 1993; Engli en Kirsivali-Farmer, 1993; Foss \& Tenholder, 1993; Warren, 1993; Daly et al, 1994; Davis-Martin, 1994). Ze willen geïnformeerd worden over de behandeling van de patiënt, over de prognose van de patiënt, over de conditie en over de mogelijkheden met betrekking tot restauratieve voorzieningen en overnachtingsmogelijkheden. Familieleden hechten grote waarde aan de mogelijkheid om met de behandelend arts te kunnen spreken. Ook vinden familieleden het belangrijk om de informatie zo eerlijk mogelijk te krijgen. Daarnaast vinden familieleden het belangrijk om op ieder moment van de dag te kunnen informeren naar hun naaste. Dit laatste niet alleen wanneer ze op de intensive care verblijven, maar ook in de thuissituatie willen ze telefonisch kunnen informeren. Men wil geünformeerd worden als de toestand van hun naaste verandert en hier niet mee geconfronteerd worden als ze weer op bezoek komen.

Minimaal één keer per dag willen familieleden structureel informatie over de patiënt. Men vindt het van het grootste belang dat de informatie in verstaanbare en begrijpelijk taal wordt gegeven (Hampe, 1975; Breu en Dracup, 1978; Molter, 1979; Daley, 1984; Bouman, 1984; Mathis, 1984; Chartier \& Coutu-Wakulczyk, 1989; Mclvor en Thompson, 1988; Dockter et al., 1988; McHale en Bellinger, 1988; Norheim, 1989; Forrester et al, 1990; Hickey, 1990; Macey en Bouman, 1991; Price et al., 1991; Leske, 1991 \& 1992; Freichels, 1991; Murphy et al., 1992; Farrel en Frost, 1992; Kleinpell en Powers, 1992; Henneman et al., 1992; Pender, 1993; Engli en Kirsivali-Farmer, 1993; Foss \& Tenholder, 1993; Warren, 1993; Daly et al., 1994; Davis-Martin, 1994). Meestal wordt informatie in vaktaal of in een min of meer moeizame vertaling van deze vaktaal gegeven.

Familieleden durven nauwelijks aan te geven deze informatie niet of gedeeltelijk te begrijpen omdat ze bang zijn daardoor niet serieus genomen te worden. Vaak worden thuis de nodige "huis-, tuin-, en keuken" encyclopedieën opengeslagen om het informatietekort aan te vullen. Men vindt het belangrijk goed geïnformeerd te worden over de bezoekuren en de daarbij behorende regels zoals "maximaal twee bezoekers per patiënt" en "niet langer dan vijf of tien minuten achter elkaar". In sommige gevallen is er op de intensive care een leeftijdslimiet, kinderen onder de zestien jaar worden vaak niet toegelaten. Henneman et al. (1992), rapporteerden dat, gestandaardiseerde informatiemomenten gerelateerd aan een flexibele bezoekregeling een positief effect hebben op de informatiebehoeften van familieleden. De invoering van een open-bezoekregeling bleek een goede voorwaarde om in informatiebehoeften te kunnen voorzien. Wanneer familieleden geconfronteerd worden met bepaalde behandelingsmethoden door eenvoudig hierbij aanwezig te zijn, wordt het vertrouwen in de behandeling bevorderd. 
Niet alleen de manier waarop de informatie werd gegeven en de persoon die de informatie gaf werd als belangrijk ervaren, maar vooral het feit dat familieleden hierbij betrokken werden en persoonlijk konden zien wat en hoe de bepaalde handelingen zich voltrokken, had een positief effect. Het gegeven dat communicatie ontstaat tussen de behandelaar en het familielid aan het bed van de patiënt "Is hij wakker?" "Weet hij dat ik er ben?" geeft de familie het gevoel van participatie en veiligheid. Het feit dat familieleden in de gelegenheid gesteld worden om de omgeving rondom de patiënt goed in zich op te kunnen nemen, de apparatuur te zien werken en geconfronteerd worden met routine-procedures maakt familieleden vertrouwd met de intensive care (Henneman et al., 1992). De verpleegkundigen de patiënt zien verzorgen door bijvoorbeeld het administreren van medicatie of de toediening hiervan, helpt de familie begrijpen wat er voor de patiënt wordt gedaan. Henneman et al. (1992) stellen dat zien meer effect heeft op het voorzien in informatiebehoeften dan horen.

Een open bezoekregeling op de intensive care impliceert grotere tevredenheid op het gebied van informatiebehoeften dan een gestructureerde bezoekregeling (Henneman et al., 1992; Titler en Walsh, 1992; Biley et al., 1993; Warren, 1993; McGaughey \& Harrisson, 1994; Lopez-Fagin, 1995). Molter, (1979) en Daley, (1984) suggereren dat artsen en verpleegkundigen door familieleden gezien worden als de meest belangrijke informatiebronnen. Verpleegkundigen worden met name benaderd met betrekking tot de patiëntenadministratie over de conditie van de patiënt en diens behandelplan, terwijl artsen meer benaderd worden over de prognose van de patiënt. Toch is het zo dat een open bezoekregeling op zichzelf geen garantie is voor een optimale vorm van informatie aan de familie. Een open bezoekregeling dient gecombineerd te worden met een spontane open communicatie tussen artsen, verpleegkundigen en familieleden (Henneman et al., 1992). Een minder conventionele, maar misschien even effectieve manier van informatie uitwisseling zou het betrekken van familieleden zijn bij de patiëntenvisites

(Henneman et al., 1992).

Het ontwikkelen van een informatieboekje dat aan de familie wordt uitgereikt wanneer de patiënt op de intensive care wordt opgenomen, wordt door de familie niet gezien als een bijdrage aan de informatiebehoefte (Henneman et al., 1992). Wel is het zo dat een informatieboekje namen van behandelaars en telefoonnummers bevat waarover de familieleden beschikking willen hebben. Het kennen van de namen van de behandelaars en het weten wie wanneer en op welk telefoonnummer te bereiken is scoorde hoog bij familieleden.

Deze bevinding suggereert dat informatie in de vorm van een informatieboekje familieleden kan ondersteunen in het onthouden van sommige informatie (Henneman et al., 1992).

Het onthouden van informatie is het meest moeilijk in de eerste periode van opname van de patiënt op de intensive care, wanneer angst bij de familieleden een grote rol speelt.

Het informatieboekje bleek een goede informatiebron (Henneman et al., 1992).

Derham (1991), concludeerde dat een pré-operatief interview met de (intensive care) patiënt, gecombineerd met een informatiebrochure een effectieve manier is om patiënten en familieleden van informatie te voorzien.

McGaughey \& Harrison (1994) ontwikkelden een informatiebrochure, ondersteund door foto's, voor patiënten en familieleden op de intensive care. De brochures worden uitgereikt aan patiënten en/of familieleden voordat de verpleegkundige begint met haar werkzaamheden bij de patiënt. 
Op deze wijze stelt zij de patiënt en/of de familie in staat te participeren in het verpleegkundig proces (McGaughey \& Harrisson, 1994). Familieleden willen weten waarom de handelingen die bij hun naaste verricht worden, uitgevoerd worden, wat het doel is en wat men ermee wil bereiken. Over het algemeen worden de reeksen van handelingen die door professionals bij intensive care patiënten worden uitgevoerd als onbegrijpelijk ervaren (Molter, 1979; Daley, 1984). Naast de handelingen staat ook de medische behandeling centraal.

Wie voert het beleid en wie is verantwoordelijk? De vele gezichten op een intensive care zijn voor familieleden moeilijk te onderscheiden in disciplines. Men weet vaak in onvoldoende mate wie de arts is en wie de verpleegkundige en wat deze disciplines precies doen. Familieleden willen dagelijks geïnformeerd worden over het ziekteverloop van hun naaste. Zij willen continu op de hoogte gesteld worden bij veranderingen, zowel positieve als negatieve, met betrekking tot het ziekteproces. Familieleden willen zeker weten dat het verantwoord is wanneer ze de intensive care verlaten, gezien de conditie van hun naaste. Men wil hierover eerst geïnformeerd worden voordat ze het ziekenhuis verlaten (Molter, 1979; Daley, 1984; Leske, 1991 \& 1992). Ook vindt men het belangrijk om van te voren geïnformeerd te worden over een eventuele overplaatsing van de patiënt. Men wil niet geconfronteerd worden met een leeg bed of een andere patiënt als men op bezoek komt. Familieleden willen, hetzij in veel minder belangrijke mate, geïnformeerd worden over de mogelijkheden met betrekking tot pastorale hulp, restauratieve voorzieningen en andere op het individu afgestemde persoonlijke informatie.

\section{Samenvatting}

Informatiebehoefte van familieleden wordt in de literatuur beschreven als een belangrijke behoefte waarin voorzien moet worden op de intensive care. Deze informatie richt zich met name op de toestand en conditie van de patiënt. Neuman (1995) benoemt enkele behoeften op het gebied van informatie in haar theoretisch model. Hoewel Neuman (1995) niet categoriseert, lijkt het, gezien het grote aantal informatieve behoeften, logisch deze behoeften te categoriseren.

\subsubsection{Behoeften aan ondersteuning}

Ondersteuning is het verlenen van bijstand en hulp aan mensen in een bijzondere situatie. Hierbij gaat het om een situatie waarin mensen niet zelfstandig in staat zijn om in hun behoeften op dat moment te voorzien. Uit de literatuur blijkt dat familieleden van intensive care patiënten minder behoeften hebben aan ondersteuning, comfort en persoonlijke zaken (Hampe, 1975; Molter, 1979; McGregor et al., 1981; Yoder en Jones, 1982; Bozett et al., 1983; Daley, 1984; O'Neill-Norris en Grove, 1986; Mclvor en Thompson, 1988; Dockter et al, 1988; McHale en Bellinger, 1988; Liddle, 1988; Norheim, 1989; Chartier \& Coutu Wakulczyk, 1989; Forrester et al., 1990; Price et al., 1991; Freichels, 1991; Koller, 1991; Titler \& Walsh, 1992; Farrel en Frost, 1992; Henneman et al., 1992; McHaffie, 1993; Pender, 1993; Biley et al., 1993). Hierbij dient wel het onderscheid te worden aangebracht tussen ondersteuning door medewerkers op de intensive care en ondersteuning door persoonlijke vrienden of familie van de familieleden.

Familieleden geven aan, het belangrijk te vinden dat er vrienden in de buurt zijn ter ondersteuning en hulp (Price et al., 1991; Breu en Dracup, 1978; Leske, 1986; O'Neill-Norris en Grove, 1986; Price et al., 1991). 
Men vindt het echter minder belangrijk om met professionals te spreken over gevoelens als schuld en angst. Familieleden vinden het belangrijk iedere dag geïnformeerd te worden. Wie dit doet is echter ondergeschikt aan de informatie zelf (Molter, 1979; Daley, 1984). Familieleden vinden het niet zo belangrijk dat bezoekuren worden aangepast aan de persoonlijke omstandigheden van het familielid (Molter, 1979; Daley, 1984; Leske, 1991 \& 1992). Ook vinden familieleden de aanwezigheid van een intensive care medewerker niet zo belangrijk wanneer ze hun naaste bezoeken. Familieleden doen dit liever alleen of in het bijzijn van een vriend of familielid. Familieleden vinden het niet belangrijk om aangemoedigd te worden om hun gevoelens de vrije loop te laten, bijvoorbeeld om te huilen. Tevens vinden zij het minder belangrijk om ondersteund en geholpen te worden bij familieproblemen. Ook vindt men het niet zo belangrijk om, wanneer men zich op de intensive care bevindt, alleen te kunnen zijn. Voor wat betreft de familieleden hoeft er geen ruimte gecreëerd te worden op de intensive care om zich terug te kunnen trekken met de bedoeling alleen te kunnen zijn. Familieleden vinden het niet belangrijk dat er iemand aanwezig is die zich speciaal op hun persoonlijke toestand richt. Ook hoeft er niet een speciaal daarvoor aangewezen persoon te zijn die ze kunnen bellen wanneer ze verhinderd zijn om op bezoek te komen. Familieleden zijn niet zo geïnteresseerd in de personen die achter de professionals schuilen, men vindt het niet belangrijk om de karakters achter de hulpverleners te kennen. Hiernaast geven familieleden aan, het minder belangrijk te vinden iedere dag met dezelfde verpleegkundige te kunnen spreken (Molter, 1979; Daley, 1984; Leske, 1991 \& 1992; Titler et al., 1992).

Een uitzondering vormen hierop pastorale hulpverleners. Familieleden die een geloof belijden vinden het, in de helft van de gevallen, belangrijk om hiervan ondersteuning te ontvangen. Familieleden vinden over het algemeen hun persoonlijke behoeften onbelangrijk.

Uit alle onderzoeken naar behoeften van familieleden op de intensive care bleek in mindere of meerdere mate dat familieleden bang zijn dat, als er aandacht besteed wordt aan hun persoonlijke behoeften, dit ten koste gaat van de aandacht voor de patiënt (Daley, 1984; Molter, 1979; Hampe, 1975).

\section{Samenvatting}

Behoeften op het gebied van ondersteuning worden, in de literatuur, door familieleden gezien als minder belangrijke behoeften op de intensive care. Alleen familieleden die een geloof belijden geven aan de aanwezigheid van pastorale hulp op prijs te stellen. Over het algemeen worden familieleden het liefst ondersteund door persoonlijke vrienden of nabije familieleden. Neuman (1995) richt haar interventiestrategie op support teams met het doel familieleden psychisch en spiritueel te begeleiden. Zij benoemt geen specifieke behoefte-items op dit gebied. Logischerwijze zou ook hier de behoeftecategorie "ondersteuning" een plaats moeten krijgen, zodat specifieke behoefte-items kunnen worden ondergebracht. Op deze wijze kan meer richting gegeven worden aan de theoretische onderbouwing van het model. 


\subsubsection{Behoeften aan toegankelijkheid}

Toegankelijkheid is de bereikbaarheid van een plaats of situatie, de mogelijkheid om deze te kunnen betreden of bezoeken maar ook het openstaan en willen aanvaarden van de mensen op die plaats of in die situatie voor andere mensen. Toegankelijkheid is in deze studie een verzamelbegrip waarbij zowel bereikbaarheid en aanvaardbaarheid als ook organisatorische voorwaarden ten behoeve van bereikbaarheid en aanvaardbaarheid zijn inbegrepen. Hoewel geen van de eerder genoemde onderzoekers deze voorwaarden met name benoemt, is het zo dat de toegankelijkheid (accessibility) op de intensive care bepalend is voor het voorzien in bepaalde behoeften (bezoekregelingen, participatie binnen het beleid). Familieleden hechten waarde aan een informatieve brochure (McGregor, Fuller en Lee, 1981; Henneman et al., 1992). McGregor, Fuller en Lee (1981), tonen aan dat een informatiebrochure een informatieverstrekkend, educatief en drempelverlagend karakter heeft. Overigens werd een dergelijke brochure niet als een eindpunt, maar meer als een stimulans tot discussie gezien.

Ook Henneman et al. (1992) zien de brochure gecombineerd met andere voorwaarden zoals open bezoekuren.

Het bezoek van een familielid aan zijn naaste op de intensive care is een belangrijke gebeurtenis (Titler \& Walsh., 1992; Biley et al., 1993). In de jaren zestig werden in de Verenigde Staten van Amerika de bezoektijden kort gehouden ( 5 minuten ieder uur) en alleen directe familieleden werden tot de intensive care toegelaten. Familieleden waren hierdoor genoodzaakt lange tijden in wachtruimtes door te brengen, waardoor gevoelens van angst en onzekerheid gevoed werden (Titler et al., 1991). Toen in diezelfde 60-er jaren de bezoekuren voor kinder intensive cares, met succes, flexibeler gehanteerd werden, ontstond er ook op de intensive cares voor volwassenen een kentering in de bezoekregeling. Bezoekregelingen werden een aandachtsgebied voor intensive care verpleegkundigen (Titler \& Walsh., 1992; Biley et al., 1993). Hoewel Dockter et al. in 1988 al aantoonden dat de nabijheid van familieleden bij de patiënt cruciaal is voor diens herstel, is het nog steeds zo dat bezoektijden gelimiteerd zijn en vaak voorbehouden aan directe familieleden (Titler \& Walsh., 1992; Biley et al., 1993). In $80 \%$ van de gevallen hanteren intensive cares regelgeving op een van de eerder genoemde gebieden (Biley et al., 1993).

Titler \& Walsh (1992) clusterden behoeften op het gebied van bezoekregelingen samen met de behoeften aan informatie omdat het bezoeken van de patiënt nabijheid en contact met de patiënt impliceert. Deze behoeften, zowel door Leske $(1991$ \& 1992) als door Titler \& Walsh (1992) behoeften aan nabijheid genoemd, zijn allen behoeften waarbij met name de toegankelijkheid van de intensive care een rol speelt. Familieleden vinden het belangrijk dat er geen vaste bezoekuren gehanteerd worden en geven de voorkeur aan een flexibele benadering. Spatt et al. (1986) noteerden het ontbreken van flexibele bezoektijden als een van de behoeften waarin niet werd voorzien. 


\section{Samenvatting}

Behoeften op het gebied van toegankelijkheid kunnen gezien worden als voorwaarden om in andere behoeften te kunnen voorzien. Met name gaat het hier dan om behoeften op het gebied van kennis (informatie) en steun (ondersteuning). Vooral behoeften op het gebied van bezoekregelingen en structuur op het gebied van informatie worden in de literatuur als belangrijke behoefte-items opgemerkt. Neuman (1995) richt zich, in haar theoretisch model, op een flexibele bezoekregeling en het betrekken van familieleden bij de zorg rondom de patiënt. Flexibele bezoekregeling kan hier gezien worden als voorwaarde, terwijl het betrekken van familieleden in de zorg meer een inhoudelijk karakter heeft waarvoor toegang binnen de intensive care gecreëerd moet worden. Beiden echter kunnen gezien worden als voorwaarden ten behoeve van informatievoorziening. Het kunnen aanschouwen van de verzorging van de patiënt heeft meer effect op het voorzien in informatiebehoeften dan het horen van informatie (Henneman et al., 1992). Ook hieruit kan afgeleid worden dat het belangrijk is de toegankelijkheid voor familieleden tot de intensive care te vergroten.

\subsection{Beïnvloedende factoren}

In verschillende studies zijn factoren gevonden die van invloed bleken op behoeften van familieleden. Stillwell (1984) toonde de invloed van leeftijd van de familieleden aan met betrekking tot de behoefte om bij de patiënt aanwezig te kunnen zijn. Molter (1979), Mathis (1984), Stillwell (1984), Spatt et al. (1986), Norheim (1989), Forrester et al.(1990), Bernstein (1990) vonden invloed van leeftijd van het familielid, relatie tot de patiënt, bekendheid op de intensive care en de diagnose van de patiënt op behoeften. Molter (1979) geeft hierbij echter aan dat deze invloed niet is gevonden bij de door haar hoogst gescoorde 10 behoeften. $\mathrm{Zij}$ stelde tevens vast dat geen van de door haar hoogst gescoorde behoeften werden beïnvloed door de sociaal-economische status van de familieleden. Spatt et al. (1986) vonden invloed van geslacht van familieleden op behoeften. Norheim (1989) noteerde marginale verschillen tussen partners en overige familieleden, terwijl Bouwman (1984) hier wel significante verschillen beschreef. Andere onderzoekers vonden geen verschillen (Price et al., 1991, Spatt et al., 1986). Bernstein (1990) vergeleek de behoeften van familieleden van neurochirurgische patiënten met de behoeften van familieleden van hartpatiënten en vond geen verschil, met uitzondering van de informatie-items. Familieleden van hartpatiënten bleken meer behoefte aan informatie te hebben dan familieleden van neurochirurgische patiënten.

Leske (1992) probeerde invloed aan te tonen van sociaal-demografische factoren (leeftijd, geslacht, relatie, diagnose van de patiënt en bekendheid van het familielid met de intensive care) op behoeften van familieleden.

Gegevens van onderzoekers die Molter's C.C.F.N.I. (1979) gebruikt hadden, werden gecombineerd. In een periode van 10 jaar (1980-1989) werden met behulp van 27 verpleegkundig onderzoekers in 15 staten (van de Verenigde Staten van Amerika) 905 familieleden van 668 patiënten geïnterviewd. 
Gebaseerd op aanbevelingen van Forrester et al. (1990) en McHale \& Bellinger (1988) werden familieleden geclassificeerd op basis van Leske's (1992) vijf sociaal-demografische kenmerken. Met betrekking tot leeftijd van de respondenten is geen significante invloed aangetoond op de behoeftecategorieën "support", "information", "proximity" en "assurance". Wel werd een verschil aangetoond bij de behoefte aan comfort. Oudere familieleden hechten duidelijk meer belang aan comfort dan jongere familieleden.

Vrouwelijke familieleden vonden de behoeften aan "support", "comfort", "information" en "proximity", duidelijk belangrijker dan mannelijke familieleden. Geen verschil werd, met betrekking tot het geslacht van de familieleden, gevonden bij de behoeften aan "assurance".

Ten aanzien van de relatie die het familielid met de patiënt had is alleen een duidelijk verschil gevonden bij de behoeften aan comfort. Volwassen kinderen van de patiënt hadden duidelijk minder behoeften aan comfort dan partners en ouders.

Bekendheid met de intensive care bleek alleen van invloed op de behoeften aan comfort en informatie. Familieleden die eerder een intensive care ervaring hadden, bleken duidelijk meer behoeften aan comfort en informatie te hebben dan familieleden die voor de eerste keer met intensive care kennis maakten.

De diagnose van de patiënt bleek alleen van invloed op de behoeften van familieleden aan comfort. Familieleden van patiënten met een primair chirurgische aandoening op de intensive care hechtten duidelijk meer waarden aan behoeften aan comfort dan familieleden van patiënten die niet met een primair chirurgische aandoening (interne aandoening of trauma) op de intensive care werden opgenomen.

Leske's meta-analyse (1992) kan gezien worden als een afspiegeling van de belangrijkste onderzoeken naar behoeften van familieleden op de intensive care die met behulp van Molter's C.C.F.N.I. (1979) zijn uitgevoerd in de Verenigde Staten van Amerika.

De onderzoeksresultaten indiceren over het algemeen behoeften aan ondersteuning, een geriefelijke, gemakkelijke omgeving, informatie, frequente bezoekmogelijkheden en bewezen betrokkenheid van de hulpverleners.

Resultaten uit Leske's materiaal $(1988,1992)$ steunen de clustering van behoefte-items in behoeftecategorieën in onderhavige studie. Het onderbrengen van behoefte-items in de driedeling (de behoeftecategorieën "ondersteuning", "informatie" en "toegankelijkheid") binnen dit onderzoek kan dan ook enerzijds theoretisch onderbouwd worden door de resultaten uit Leske's studies $(1988,1992)$ waaruit de behoeften aan ondersteuning en informatie duidelijk naar voren komen. Een gemakkelijke, geriefelijke omgeving en frequente bezoekmogelijkheden kunnen gezien worden als de toegankelijkheidsfactoren die in dit onderzoek gemeten worden. Anderzijds kan Neuman's (1995) interventieschema (tabel 2.2.1) bijdragen tot toepasbaarheid van behoeftecategorieën in de praktijk. 


\section{Samenvatting}

Binnen sommige onderzoeken worden factoren benoemd die van invloed zijn op de behoeften van familieleden. In tabel 2.4 wordt een overzicht getoond van de beïnvloedende factoren uit de literatuur. Opvallend is dat alleen Leske (1992) als enige onderzoeker de invloed van geslacht van familieleden op behoeften aantoont. Tevens valt op dat Bouwman (1984) alleen invloed van de relatie van familieleden met de patiënt op behoeften aantoont.

Tabel 2.4 Beïnvloedende factoren uit de literatuur

\begin{tabular}{|c|c|c|c|c|c|c|c|c|c|}
\hline 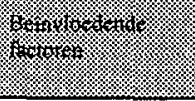 & (1) & $\frac{19}{49}$ & 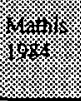 & 4 & 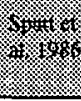 & 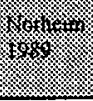 & $\frac{1}{4}$ & (6) & (1) \\
\hline Leeftijd & + & - & + & + & + & + & + & + & + \\
\hline $\begin{array}{l}\text { Geslacht } \\
\text { Relatie met de }\end{array}$ & + & + & + & + & t & t & $t$ & + & + \\
\hline $\begin{array}{l}\text { Relatie met de } \\
\text { patient }\end{array}$ & & & & & & & & & \\
\hline $\begin{array}{l}\text { Bekendheid met de } \\
\text { ICU }\end{array}$ & + & - & + & + & + & + & + & + & + \\
\hline Opname-indicatie & + & - & + & + & + & + & + & + & + \\
\hline
\end{tabular}

$+=$ invloed

- $=$ geen invloed

\subsection{Coping}

Coping is een psychologisch concept waarover de afgelopen dertig jaar duizenden publicaties zijn verschenen (Furda, 1995). Tellegen en Winnubst (1986, uit Furda, 1995) vonden in 36 publicaties 14 verschillende definities van coping. In dit proefschrift wordt de copingtheorie van Lazarus (1966) gehanteerd.

\section{De copingtheorie van Lazarus}

Het meest invloedrijke theoretische kader over coping werd door Lazarus (Lazarus, 1966; Lazarus en Launier, 1978; uit Furda, 1995) geformuleerd. Volgens deze theorie is de betekenis van een stressor voor het individu bepalend voor de gezondheidseffecten van deze stressor. Het toekennen van betekenis gebeurt tijdens een proces dat appraisal genoemd wordt. Dit proces kent twee fasen, te weten primary appraisal en secondary appraisal.

Primary appraisal is een oordeel over de relevantie, het uitdagende of het bedreigende van een gebeurtenis (Folkman, 1984, uit Furda, 1995). Secondary appraisal is een oordeel over de mogelijkheden die het individu ter beschikking denkt te hebben om op de uitdaging of de bedreiging te reageren. Deze oordelen resulteren in copinggedrag, ofwel cognitieve en gedragsmatige inspanningen om de stressor te beheersen, te reduceren of te tolereren (Folkman, 1984, uit Furda, 1995). De theorie van Lazarus (1966) gaat uit van een dichotomie in de functies van copinggedrag. Onderscheiden worden emotie-gerichte coping en probleem-gerichte coping. De functie van emotie-gerichte coping is beïnvloeding van de emotionele toestand ten gevolge van de stressor. De functie van probleem-gerichte coping is de beïnvloeding van de stressor zelf (Furda, 1995). 
Iedereen krijgt in zijn leven meerdere keren, en soms voortdurend, te maken met problemen en gebeurtenissen die aanpassend gedrag vereisen. Echter lang niet iedereen, die een ernstige gebeurtenis meemaakt of onder chronische moeilijkheden gebukt gaat, blijkt ook daadwerkelijk een stoornis te krijgen. Om deze differentiële respons te kunnen verklaren zijn een aantal factoren gepostuleerd die een mediërende rol zouden spelen in de relatie tussen omgevingsgebonden factoren en stoornissen. In de literatuur wordt een groot aantal factoren genoemd, waarvan verondersteld wordt dat zij de kans op het ontstaan van stoornissen, in combinatie met een uitlokkende factor (provoking agent zoals life event) beïnvloeden. Kupst (1993) spreekt onder andere over sociaal-demografische factoren als sociaaleconomische status. Enkele van deze mediërende factoren hebben betrekking op de wijze waarop individuen een gebeurtenis waarnemen, interpreteren en daarop reageren. Uit onderzoek is gebleken dat er op dit punt grote verschillen tussen mensen bestaan (Kupst, 1993). Eveneens is gebleken dat de manier van omgaan met belastende situaties en gebeurtenissen van invloed is op het psychologisch, fysiek en sociaal welbevinden (Boumans, 1990). In de praktijk blijkt dat het moeilijk is onafhankelijke copingvormen te onderscheiden. Dit is voorstelbaar als men bedenkt dat de meeste gedragingen zich niet uitsluitend op een afgebakend terrein richten, maar dat ze tegelijkertijd, of in latere instantie, eveneens elkaar beïnvloeden. Ook kunnen wijzigingen in de situatie, in de waarneming daarvan of in de ondervonden spanning, weer aanleiding geven tot het gebruik van andere copingvormen. Dit probleem komt later terug bij het operationaliseren van de copingvormen.

\subsubsection{Coping geconceptualiseerd als persoonlijkheidskenmerk}

Coping geconceptualiseerd als persoonlijkheidskenmerk gaat er van uit dat mensen gedragsmatig en cognitief consistent zijn in verschillende problematische situaties. Voor dit reactiepatroon wordt de term copingstijl gebruikt (Van de Willige et al., 1983, uit Janssen et al., in voorbereiding). Individuele verschillen houden verband met vroegere leerervaringen en met persoonlijkheidskenmerken en gedragsstijlen. Voor het begrip "stijl" wordt een ruime betekenis gebruikt dat zich kenmerkt door een zekere stabiliteit, maar in principe veranderbaar is. De Utrechtse Coping Lijst, U.C.L.,( Janssen et al., in voorbereiding) is het best te plaatsen onder deze benadering. Dit betekent niet dat de gehanteerde copingstrategieën gezien worden als onveranderlijke kenmerken of eigenschappen, maar wel dat er vanuit gegaan wordt dat individuen voorkeur hebben voor bepaalde (combinaties van) copingvormen over verschillende situaties heen: de copingstijl.

\subsubsection{Effectiviteit van coping}

De bevinding dat de manier van omgaan met belastende situaties en gebeurtenissen van invloed is op het psychisch, fysiek en sociaal welzijn van mensen impliceert dat sommige copingvormen effectiever zijn dan andere, in termen van probleemoplossing. Effectief copinggedrag betekent dat men door een bepaald copingpatroon gezondheidsklachten voorkomt en/of het welzijn in stand houdt of bevordert, dat men zich in sociaal opzicht prettig voelt en/of zijn gevoel voor zelfwaardering versterkt (Schreurs et al., 1993). 
In zijn algemeenheid kan niet worden gesteld dat een bepaalde copingvorm effectiever is dan een andere. Indien men hier uitspraken over zou willen doen, is het nodig dat eveneens de aard van de gebeurtenis of de omstandigheid in beschouwing wordt genomen.

Situationele factoren, zoals de door Dohrenwend en Dohrenwend (1974, uit Furda, 1995) onderscheiden dimensies van gebeurtenissen en problemen, zoals de duur, frequentie, intensiteit, voorspelbaarheid en controleerbaarheid, bepalen mede welke copingvormen in een bepaalde situatie wel effectief zijn en welke niet (Schreurs et al., 1993)

Indien een situatie bijvoorbeeld onveranderd blijft, zal een strategie waarbij men actief blijft proberen de situatie aan te pakken niet leiden tot het gewenste effect (reductie van stress). In dit geval zal een vorm van cognitieve herstructurering mogelijk effectiever zijn. In het verlengde van deze vraagstelling ligt de constatering van Folkman en Lazarus (1980, uit Furda, 1995) dat de plaats of het gebied waar het probleem zich voordoet mede bepalend is voor de copingvormen die men zal of kan gebruiken. Bepaalde copingvormen die in de ene situatie wel adequaat zijn, kunnen in de andere situatie een tegenovergesteld effect hebben (Janssen et al., in voorbereiding). Hierbij speelt ook het tijdsperspectief een rol, waarbij men een onderscheid kan maken in effecten op korte en op lange termijn. Vormen van coping die in eerste instantie een gunstig effect hebben, behoeven dat op langere termijn niet te hebben. Het gebruik van een copingstijl als "vermijden en afwachten" bijvoorbeeld kan tijdelijk effectief zijn, omdat het de fysiologische en emotionele spanning reduceert. Indien de bron van het conflict echter aanwezig blijft, kan dezelfde vorm, als zij vaak wordt aangewend, theoretisch wel leiden tot gezondheidsstoornissen. Het tijdig inzetten van een ander copinggedrag zou dan positiever kunnen werken. Tenslotte zijn ook eigenschappen van de persoon in kwestie van belang, zoals motivatie, copingvaardigheden en beschikbare hulpbronnen. De effecten van het toepassen en/of uitvoeren van een actief-instrumenteel copinggedrag hangen dus zowel van de aard van het probleem af als van de kwaliteiten en vaardigheden van de persoon in kwestie.

Er bestaat nog geen eenduidig beeld over de effectiviteit van de verschillende copingstrategieën ten aanzien van diverse situaties en gebeurtenissen. In recent onderzoek naar de effectiviteit van het copinggedrag wordt de problematiek van de bepaling van het criterium voor effectiviteit ten dele omzeild door individuen te vragen in hoeverre men bij dat gedrag baat heeft gehad of dat het gedrag effectief is geweest. Dit is echter ten dele een oplossing omdat vaak impliciet blijft wat het gedrag in de concrete situatie betekent en of het gedrag effectief is geweest in termen van het oplossen van het probleem, verbetering van de gezondheid of het psychisch functioneren.

De Utrechtse Copinglijst (UCL, Janssen et al., in voorbereiding) is de meest gebruikte Nederlandse coping zelfrapportage vragenlijst. De betrouwbaarheid en validiteit van deze lijst zijn reeds meerdere malen onderwerp van onderzoek geweest (Schreurs et al., 1993). De UCL komt uit deze analyses naar voren als een goed instrument. Volgens de makers is het instrument het beste te plaatsen onder de opvatting van coping als persoonskenmerk. 
Het is gebaseerd op de veronderstelling dat mensen over een aantal situaties bepaalde manieren van coping prefereren (Schreurs et al., 1993). Uitvoerige analyses op data-materiaal van verschillende onderzoeken in Utrecht en Maastricht leverden een 15-item versie op die vier copingstijlen meet, te weten (1) "actief het probleem aanpakken", (2) "sociale steun zoeken", (3) "afwachten en vermijden" en (4) "palliatief gedrag" (Janssen et al., in voorbereiding).

Om inzicht te krijgen in de aard van bovengenoemd copinggedrag, zijn, in onderstaand schema, de vier copingstijlen toegewezen aan "fight" ("het probleem aanpakken") en "flight" ("voor het probleem wegvluchten") gedrag (Janssen et al., in voorbereiding). Tevens wordt hierbij het instrumentele ("actief aanpakken" en "afwachten en vermijden") of emotionele karakter ("sociale steun zoeken" en "palliatief gedrag") van dit gedrag aangegeven (Janssen et al., in voorbereiding).

Tabel 2.5.2 Overzicht copingstijlen

\begin{tabular}{l|l|l} 
& Instrumenteel & Emotioneel \\
\hline Fight & Actief aanpakken & Sociale steun zoeken \\
\hline Flight & Afwachten/vermijden & Palliatief gedrag
\end{tabular}

Zoals eerder is beschreven kan niet zonder meer worden gesteld dat een bepaalde copingvorm effectiever is dan een andere. Indien men hierover uitspraken zou willen doen is het nodig dat eerst de aard van de omstandigheid of gebeurtenis in beschouwing wordt genomen. Van belang hierbij zijn tevens de duur, frequentie, intensiteit, voorspelbaarheid en controleerbaarheid (Schreurs et al., 1993). Copinggedrag dat in de ene situatie effectief is, kan in een andere situatie ineffectief blijken.

Copinggedrag in relatie tot behoeften van familieleden op de intensive care vergt inzicht in de aard van de omstandigheid waarin familieleden op de intensive care verkeren.

Familieleden worden vaak plotseling geconfronteerd met de opname van hun naaste en bevinden zich van het ene op het andere moment in een situatie van angst, bedreiging en afhankelijkheid. Voorspelbaarheid en controleerbaarheid van deze omstandigheid is niet of nauwelijks aanwezig. De duur van de omstandigheid hangt af van de opnameperiode van de patiënt. Een aantal intensive care patiënten zijn eerder opgenomen geweest op een intensive care, zodat de frequentie van de omstandigheid voor de familie soms herkenbaar is.

De intensiteit van de omstandigheid is groot, familieleden zijn angstig, onzeker en voelen zich bedreigd, machteloos en afhankelijk (Daley, 1984; McHaffie, 1993).

In relatie tot behoeften van familieleden van intensive care patiënten kan copinggedrag gezien worden als bepaald geprefereerd (zie ook hoofdstuk 6) gedrag dat in bepaalde mate de behoeften van familieleden beïnvloed. Om hierover een indruk te krijgen wordt in onderstaand schema verondersteld effect van copingstijlen (Janssen et al., in voorbereiding) benoemd waarbij de copingstijlen zowel zijn toegewezen aan "fight"- en "flight" -gedrag als aan het instrumentele of emotionele karakter van dit gedrag. 


\begin{tabular}{|l|c|c|c|c|}
\cline { 2 - 5 } \multicolumn{1}{c|}{} & Actief aanpakken & Afwachten en vermijden & Sociale steun zoeken & Palliatief gedrag \\
\cline { 2 - 6 } & Fight & Flight & Fight & Flight \\
\cline { 2 - 6 } & \multicolumn{2}{|c|}{ Instrumenteel } & \multicolumn{2}{c|}{ Emotioneel } \\
\hline $\begin{array}{l}\text { Informatie } \\
\text { (instrumentele benadering) }\end{array}$ & + & - & + & - \\
\hline $\begin{array}{l}\text { Ondersteuning } \\
\text { (sociaal-emotionele benadering) }\end{array}$ & $(-)$ & - & $(+)$ & 0 \\
\hline $\begin{array}{l}\text { Toegankelijkheid } \\
\text { (structuur gerichte benadering) }\end{array}$ & + & & + & 0 \\
\hline
\end{tabular}

$+\quad=$ positief effect

$-\quad=$ negatief effect

() = wellicht (positiefinegatief) effect

$0=$ geen effect

\section{Actief aanpakken}

Zoals in figuur 2.5.2.1 is te zien wordt "actief aanpakken" als verondersteld effectief gedrag gekenmerkt om informatie over de situatie binnen de intensive care en toegankelijkheid op de intensive care te bevorderen, met andere woorden: de copingstijl "actief aanpakken" wordt verondersteld een positieve invloed te hebben op behoeften aan informatie en toegankelijkheid. Hierbij wordt eveneens verondersteld dat het instrumentele karakter van de copingstijl "actief aanpakken" ten opzichte van het instrumentele karakter van behoeften aan informatie en de op structuur gerichte behoeften aan toegankelijkheid waarschijnlijk een rol spelen. Ten aanzien van behoeften aan ondersteuning wordt verondersteld dat de copingstijl "actief aanpakken" wellicht negatieve invloed heeft op de behoeftecategorie "ondersteuning". Dit is gebaseerd op de verwachting dat de "fight" gerichte aanpak waardoor deze copingstijl wordt gekenmerkt een omgekeerd evenredig effect heeft op de copingstijl "sociale steun zoeken".

\section{Sociale steun zoeken}

Ten aanzien van de copingstijl "sociale steun zoeken", wordt deze copingstijl verondersteld effectief te zijn als het gaat om behoeften aan ondersteuning. Zowel de copingstijl "sociale steun zoeken" als de behoeftecategorie "ondersteuning" hebben beiden een emotioneel karakter en als zodanig wordt verondersteld dat de copingstijl "sociale steun zoeken" een positief effect heeft op behoeften aan ondersteuning. Ondanks de instrumentele en op structuur gerichte karakters van de behoeftecategorieën "informatie" en "toegankelijkheid" wordt verondersteld dat de copingstijl "sociale steun zoeken" wellicht een positief effect heeft op beide behoeftecategorieën. Deze veronderstelling is gebaseerd op de "fight" gerichte aanpak waardoor de copingstijl "sociale steun zoeken" wordt gekenmerkt. Hierdoor zullen waarschijnlijk ook de behoeften aan informatie en toegankelijkheid toenemen. 


\section{Afwachten en vermijden}

In figuur 2.5.2.1 is te zien dat de copingstijl "afwachten en vermijden" als ineffectief copinggedrag wordt gekenmerkt. Ten aanzien van alle behoeftecategorieën wordt verwacht dat de copingstijl "afwachten en vermijden" een negatief effect heeft. Juist het instrumenteleen "flight" karakter van de copingstijl "afwachten en vermijden" wordt verondersteld hiertoe bij te dragen.

\section{Palliatief gedrag}

Ook de copingstijl "palliatief gedrag" wordt verondersteld ineffectief te zijn in relatie tot behoeften van familieleden. Deze copingstijl kenmerkt zich door het ontbreken van initiatieven en als zodanig wordt verwacht dat deze stijl geen of nauwelijks invloed heeft op behoeften van familieleden. Ook is het zo dat dit copinggedrag situationeel en dus gerelateerd aan de situatie op de intensive care is. Als zodanig heeft dit gedrag een sterk relativerende werking en helpt het familieleden de situatie de baas te blijven. Het emotionele- en "flight" karakter van deze copingstijl doet tevens vermoeden dat deze stijl op termijn een negatieve invloed heeft op behoeften aan informatie.

Omdat de algemene categorie "begeleiding" het totaal vormt van de drie afzonderlijke behoeftecategorieën en herhaling van veronderstellingen niet wenselijk wordt geacht, is besloten de veronderstelde effecten van copinggedrag op behoeften van familieleden alleen te bespreken voor de eerder genoemde drie behoeftecategorieën. Op deze vooronderstellingen wordt in de resultaat hoofdstukken ( 5 en 6 ) verder ingegaan.

\subsubsection{Coping als begrip binnen de verpleging}

Coping zou een essentieel begrip in de verpleging kunnen zijn. Zonder een juist inzicht in de copingfactoren die bij ziekte meespelen in de problemen waaraan de patiënt en zijn familie het hoofd moeten bieden, kunnen pogingen hen te helpen hun doel missen of zelfs schadelijk zijn. Voorop staat het besef dat hoe goed iemand de situatie aan kan, bepalend kan zijn voor zijn psychisch welzijn en levensbevrediging (McHaffie, 1993). In dit kader kan men de vraag stellen hoe goed iemand is voorbereid op zijn rol als familielid van een intensive care patiënt. Alleen al het verblijf op een intensive care leidt tot stress. Als familieleden hier plotseling mee geconfronteerd worden en/of te weinig informatie krijgen zijn ze dubbel gehandicapt en zullen ze zich machteloos en hulpeloos voelen.

\subsubsection{Copinggedrag en behoeften van familieleden}

Coping moet gezien worden als een dynamisch proces (McHaffie, 1993), het is geen statische, eenmalige inspanning. Het verandert van aard en kracht, afhankelijk van de aanwijzingen en signalen die de persoon per situatie onderzoekt, selecteert en beoordeelt. Coping veronderstelt geen totale overwinning of volledige overgave, maar een streven naar een aanvaardbaar proces (McHaffie, 1993). Stel dat iemand geconfronteerd wordt met een plotselinge opname van zijn partner op de intensive care. Het is bekend dat mensen een nare boodschap niet sneller laten doordringen dan ze kunnen verdragen, tijd is een essentiële factor. De verpleegkundige die met de zorg voor de betreffende familie is belast, zal beseffen dat het geen zin heeft hem te overladen met informatie over behandelingen, bijwerkingen, complicaties en de mogelijke prognose omdat hij niet in staat zal zijn het allemaal op te nemen. 
Als mensen gespannen en angstig zijn, pikken ze alleen de informatie op die ze op dat moment kunnen hanteren.

Andere informatie moeten ze herhaaldelijk horen voordat het tot ze doordringt.

Sommige familieleden trekken van de ene hulpverlener naar de andere, op zoek naar diegene die de meest optimistische prognose geeft. Opname van een patiënt op een intensive care gebeurt meestal plotseling en onvoorbereid. Familieleden van deze categorie patiënten worden geconfronteerd met meerdere stressoren en zullen veelal niet in staat zijn om hierop effectief te reageren. De meeste familieleden verwachten over het algemeen niet dat intensive care verpleegkundigen of ander gezondheidszorgpersoneel zich ontfermen over hun conditie, maar verwachten dat hulpverleners zich op de patiënt richten (Schlump-Urquhart, 1990). Toch is het van groot belang dat in de psychosociale- en emotionele zorg voor familieleden van intensive care patiënten wordt voorzien. Familieleden zullen in hun behoeften moeten worden onder-steund willen zij in staat zijn de patiënt positief te benaderen (Schlump-Urquhart, 1990). Hierbij is het van belang dat verpleegkundigen inzicht hebben in het copinggedrag van familieleden. Wanneer verpleegkundigen in staat zijn adequaat en inadequaat copinggedrag te herkennen ontstaat de mogelijkheid hierop te anticiperen en familieleden beter in staat te stellen om met de crisissituatie om te gaan.

\subsubsection{Coping in relatie tot sociaal-demografische factoren}

Naast inzicht van verpleegkundigen in copinggedrag van familieleden is het van belang dat verpleegkundigen kennis hebben van de factoren die copinggedrag kunnen beïnvloeden. Hierdoor ontstaat sneller inzicht in het copinggedrag van familieleden en kan beter geanticipeerd worden op behoeften van familieleden. De meest frequent geciteerde sociaaldemografische factor die van invloed is op de copingstijl van familieleden is de sociaaleconomische status (Kupst, 1993). Alhoewel de definities hiervan variëren is de algemene bevinding dat hoe lager de sociaal-economische status van het familielid is, hoe moeilijker deze kunnen omgaan met problemen. Lage scholing, beroep en inkomen leveren problemen op met betrekking tot informatie over de medische behandeling, het begrijpen van uitleg op het gebied van diagnostiek en het nakomen van afspraken.Een hogere sociaal-economische status leidt tot meer inzicht in copingvaardigheden.

Aan de andere kant is het zo dat hoger opgeleide familieleden de medewerkers in het ziekenhuis anders benaderen. Ook de familieleden verdiepen zich in behandelingsmethoden en bewandelen meerdere wegen om aan de vereiste informatie te komen (Kupst, 1993). Een van de belangrijkste factoren binnen coping is een open communicatie tussen familieleden en zorgverleners (Kupst, 1993). Familieleden die weigeren de emst van de situatie rondom hun naaste te bespreken blijken meer problemen te hebben met het onder ogen zien van de ziekte en de behandeling.

Familieleden die onderling van mening verschillen over hun rollen met betrekking tot de behandeling van hun naaste, of bij elkaar schuldgevoelens oproepen lopen risico bij het omgaan met de situatie. In deze setting lopen echtparen meer risico om emotionele- en gedragsproblemen te ontwikkelen (Kupst, 1993). Familieleden die met financiële problemen te kampen hebben, die in een huwelijkscrisis verkeren of in andere soortgelijke problematiek verkeren kunnen overstelpt worden door een nieuwe crisissituatie (Kupst, 1993). 
Meerdere stress-situaties tegelijkertijd kunnen aanleiding zijn tot onvermogen tot coping ten opzichte van de nieuwe stress-situatie. Wanneer andere stress-situaties tijd en energie van familieleden vragen kan de nieuwe stress-situatie genegeerd worden of inadequaat gehanteerd. Factoren als leeftijd en geslacht zijn niet van invloed op het copinggedrag van familieleden (Kupst, 1993), terwijl psychopathologie van familieleden wel als een risicofactor wordt aangemerkt. Het gebruik van medicijnen en alcohol kan een negatieve invloed hebben op het copinggedrag van familieleden.

Kupst (1993) concludeerde dat adequaat copinggedrag van familieleden sterk correleerde met het copinggedrag van de patiënt. Kupst, (1993), concludeerde dat, familieleden die in eerdere situaties een bepaalde copingstijl hanteerden, in een later stadium beter in staat waren probleemsituaties het hoofd te bieden. Dit impliceert echter niet dat familieleden steeds hetzelfde copinggedrag vertonen en als zodanig bijvoorbeeld steeds ineffectief copinggedrag vertonen bij stress-situaties (Kupst, 1993). Over het algemeen is er consensus over een adequaat copinggedrag bij familieleden (Kupst, 1993). Er zijn vele copingstrategieën. Familieleden ontwikkelen voorkeursstrategieën. Sommige familieleden zijn verbaal sterk en geven de voorkeur aan het bepreekbaar maken van hun problemen, anderen geven er de voorkeur aan dit niet te doen. Sommige familieleden zoeken hulp in groepsverband, anderen zijn meer individueel ingesteld. Sommige familieleden hebben informatie nodig om zichzelf onder controle te krijgen, anderen worden hier alleen maar angstig van. Over het algemeen echter zijn een open communicatie en een levenshouding die zich beperkt van dag tot dag goed verenigbaar met effectief copinggedrag van familieleden (Kupst, 1993).

Nolan et al. (1992) onderzochten ervaren stress door familieleden van harttransplantatiepatiënten en gehanteerde copingstrategieën. De meest stressvolle gebeurtenissen die door familieleden ervaren werden, waren (1) verwaarlozing van het thuisfront, zoals sociale contacten en de verzorging van de kinderen, om zo alle aandacht te kunnen geven aan het zieke familielid (2) het ernstig ziek zijn van een ouder of partner, (3) het niet meer kunnen opbrengen van de financiële kosten met betrekking tot de behandeling van de patiënt, (4) het niet meer kunnen opbrengen van de financiële kosten met betrekking tot het dagelijks onderhoud van de familieleden (eten, kleding, energiekosten) en (5) het ernstig ziek zijn van een naaste die geen ouder of partner is. De copingstrategieën van familieleden van harttransplantatie-patiënten, die door Nolan et al. (1992) gevonden werden zijn verdeeld in meest en minst gehanteerde copingstrategieën.

De meest gehanteerde strategieën zijn de kracht hebben om problemen te hanteren, de problemen onder ogen zien om ze vervolgens slagvaardig op te lossen en ondersteuning en hulp zoeken bij vrienden. De minst gehanteerde strategieën zijn televisie kijken, de overtuiging hebben dat geluk een grote rol speelt in het oplossen van problemen en geloven dat, als je maar lang genoeg wacht, de problemen vanzelf opgelost worden.

De meest frequente stressbron, het laten liggen van een aantal aandachtsgebieden in de thuissituatie, werd eveneens gevonden door Murdaugh en Mishel (I987, uit Nolan et al., 1992). $\mathrm{Zij}$ beschreven dat familieleden zich, met name gedurende de wachttijd tot de transplantatie (patiënten zijn dan inmiddels gescreend en geaccepteerd voor transplantatie en wachten op een donor), afwenden van de dagelijkse werkzaamheden thuis om zo hun volledige aandacht op de patiënt te kunnen richten. 
Het feit dat geen van de respondenten vond dat er sprake was van extreme stress (Murdaugh en Mishel, 1987, uit Nolan et al., 1992) is bijzonder te noemen. Nolan et al. (1992) denken dit te kunnen toeschrijven aan de rol die transplantatiecoördinatoren spelen gedurende de wachttijd. Ook zou het zo kunnen zijn dat het gevoel van hoop dat familieleden hebben helpt bij stressreductie. De meest gehanteerde copingstrategie "weten dat de familie de kracht heeft om de problemen te hanteren" zou op hoop kunnen wijzen. Daley (1984) stelt dat hoop de angst om een naaste te verliezen kan reduceren.

\subsection{Samenvatting}

De bevindingen uit de hiervoor genoemde studies suggereren dat copingstrategieën van invloed zijn op de behoeften die ontstaan wanneer familieleden in een stress-situatie komen te verkeren. Het gegeven dat coping een complex en individueel mechanisme is, impliceert enerzijds dat familieleden in dezelfde situatie verschillende copingstrategieën kunnen hanteren. Anderzijds is het belangrijk ieder familielid als individu te beschouwen. Ieder familielid is anders en kan als zodanig ook anders reageren. Voor verpleegkundigen impliceert dit, met betrekking tot behoeften van familieleden, inzicht in copingstrategieën en kennis van de factoren die hierop van invloed zijn. 


\section{ONDERZOEKSVRAGEN EN ONDERZOEKSMODEL}

\subsection{Inleiding}

De bevindingen in het voorafgaande hoofdstuk leiden tot de conclusie dat de resultaten (categorisering van behoefte-items en aangetoonde invloed van sociaal-demografische- en overige factoren) uit de studies van Leske $(1988,1991,1992)$ toegepast binnen het interventieschema van Neuman (1995) en de copingtheorie van Lazarus (1966) een geschikt uitgangspunt vormen voor de concrete invulling van het theoretisch kader van deze studie (figuur 1.2). Tevens blijkt dat een aantal wijzigingen de bruikbaarheid van het interventieschema kan bevorderen. Het categoriseren van behoefte-items in behoeftecategorieën en het betrekken van een aantal specifieke factoren (sociaal-demografische-, intensive care gelieerde-ziektegebonden- en copingfactoren) is enerzijds gebaseerd op theoretisch overwegingen en anderzijds op de specifieke kenmerken van de intensive care.

In dit hoofdstuk zal eerst het onderzoeksmodel gepresenteerd worden. Vervolgens zullen de onderzoeksvraagstellingen worden uitgewerkt en de verschillende variabelen afzonderlijk worden toegelicht.

\subsection{Onderzoeksmodel}

Het onderzoeksmodel in deze studie wordt gepresenteerd in figuur 3.2.

Figur 3.2 Onderzoeksmodel

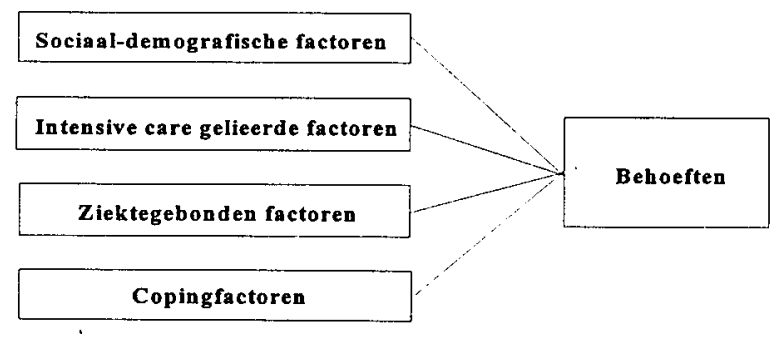

\subsection{Onderzoeksvragen}

In deze paragraaf zal een nadere uitwerking van de probleemstelling van het onderzoek in specifieke onderzoeksvragen plaatsvinden. Daarbij is gekozen voor een verklarende aanpak met open vraagstellingen. Een aantal vraagstellingen zijn direct uit het onderzoeksmodel (figuur 3.2) af te leiden. Zij vormen dan ook de centrale vraagstellingen in deze studie. Naast deze centrale vragen kunnen echter nog een aantal deelvragen opgesteld worden. Allereerst zullen de centrale vragen geformuleerd worden om vervolgens de deelvragen te behandelen. 


\section{Centrale vraagstellingen}

\section{Welke behoeften hebben familieleden van intensive care patiënten?}

Op grond van de literatuurstudie wordt verwacht dat familieleden van intensive care patiënten behoeften hebben op het gebied van informatie, ondersteuning en toegankelijkheid. Hoewel veel onderzoekers over het algemeen behoeften hebben gemeten op item niveau en ook Neuman (1995) in haar interventieschema slechts enkele behoeften benoemt, is uit de literatuur en uit het eigen onderzoek af te leiden dat behoeften van familieleden onder te brengen zijn in drie, duidelijk af te bakenen, gebieden. Deze studie richt zich, op grond van bovengenoemde argumentatie, dan ook op deze drie gebieden (informatie, ondersteuning en toegankelijkheid). Hoewel geen van de genoemde onderzoekers zich richt op behoeften van familieleden aan begeleiding in het algemeen, waarbij begeleiding gezien dient te worden als kapstok voor de drie behoeftecategorieën, richt deze studie zich, naast de drie behoeftecategorieën, ook op behoeften aan begeleiding.

Naast het belang van behoeften van familieleden van intensive care patiënten is het van belang te weten wie, in de ogen van familieleden, in de behoeften zou moeten voorzien.

Hierover hebben slechts enkele onderzoekers een uitspraak gedaan (Molter, 1979; Daley, 1984). Tevens vormt in deze studies de keuze tussen uitsluitend de arts en de verpleegkundige een beperking. Nog belangrijker is te weten of er daadwerkelijk in behoeften op de intensive care wordt voorzien en door wie. De laatste twee vragen zijn slechts in enkele andere studies besproken (Quinn et al., 1996; Zazpe et al., 1997). Hierbij dient te worden opgemerkt dat deze onderzoekers uitsluitend tevredenheid hebben gemeten op behoefte-item niveau.

Geen van de onderzoekers spreekt over eventueel sociale wenselijk antwoordgedrag van de respondenten. Deze studie richt zich dan ook niet alleen op behoeften van familieleden, maar ook op de vragen wie in de behoeften zouden moeten voorzien, of er in de behoeften is voorzien en door wie er in de behoeften is voorzien. Met name de laatste vragen geven zicht op de legitimatie van familiebegeleiding door verpleegkundigen of anderen en de kwaliteit van familiebegeleiding op de intensive care.

\section{Wat is het effect van onafhankelijke- en overige factoren op behoeften van familieleden?}

Uit de literatuur (hoofdstuk 2) is gebleken dat sociaal-demografische factoren zoals leeftijd, geslacht en de relatie van het familielid met de patiënt, van invloed zijn op behoeften van familieleden op de intensive care. Ook ziektegebonden factoren, zoals bekendheid met de intensive care, de opname-indicatie en de diagnose van de patiënt, spelen in de literatuur een beïnvloedende rol. Intensive care gelieerde factoren zoals wachttijd op opname of het feit dat de opname van de patiënt is uitgesteld nadat deze gepland is, zijn niet eerder onderzocht, terwijl, in dit onderzoek, wel invloed wordt verondersteld. Tot slot wordt in deze studie verwacht dat copinggedrag van familieleden van invloed is op behoeften van familieleden. Ondanks het feit dat veel studies verricht zijn naar copinggedrag, is slechts een enkele studie gedaan naar copinggedrag bij familieleden van harttransplantatiepatiënten gedurende de wachtperiode op het donorhart (Nolan et al., 1992). Over het algemeen wordt, in de literatuur, de nadruk gelegd op de relatie tussen ingrijpende gebeurtenissen en copingstijlen (Feij et al., 1990). Om bovenstaande redenen wordt in dit onderzoek het effect van onafhankelijke en overige factoren op behoeften van familieleden onderzocht. 


\section{Deelvraagstellingen}

Eerst zullen de (deel)vraagstellingen die behoren tot de eerste centrale onderzoeksvraag behandeld worden om vervolgens de (deel)vraagstellingen behorend bij de tweede centrale onderzoeksvraag te behandelen.

\section{Deelvraagstellingen eerste centrale onderzoeksvraag:}

1a Welke behoeften hebben familieleden op de intensive care aan informatie?

Wie is de gewenste informatieverstrekker?

Is er in de gewenste behoeften aan informatie voorzien?

Wie heeft in de gewenste behoeften aan informatie voorzien?

1b Welke behoeften hebben familieleden op de intensive care aan ondersteuning?

Wie is de gewenste ondersteuner?

Is er in de behoeften aan ondersteuning voorzien?

Wie heeft in de gewenste behoeften aan ondersteuning voorzien?

1c Welke behoeften hebben familieleden op de intensive care aan toegankelijkheid?

Is er in de behoeften aan toegankelijkheid voorzien?

Eerder genoemde (deel) vraagstellingen zijn vooral belangrijk omdat ze de behoeften in de drie deelgebieden in kaart brengen. Daarbij komt dat slechts enkele onderzoekers de vraag hebben gesteld wie er in de behoeften zou moeten voorzien. Hier konden familieleden uitsluitend kiezen tussen de arts en de verpleegkundige. In deze studie wordt de keuze voor de gewenste behoefteverstrekker vrijgelaten. Op deze wijze kunnen familieleden hun werkelijke voorkeur aangeven. Geen van de studies naar behoeften van familieleden geeft antwoord op de vraag of er daadwerkelijk in behoeften is voorzien en door wie. Wel is het zo dat enkele onderzoekers (Quin et al.,1996; Zazpe et al.,1997) tevredenheid hebben gemeten op behoefte-item niveau.

Het belang van deze vragen is groot, omdat deze een indicatie voor de kwaliteit van zorg voor familieleden vormen. De laatste (deel)vraagstelling "welke behoeften hebben familieleden op de intensive care aan toegankelijkheid?" bestaat, in tegenstelling tot de andere twee (deel)vraagstellingen, slechts uit één subvraag, namelijk of er in de behoeften is voorzien. Wie de wenselijke behoefteverstrekker is en of er daadwerkelijk in de behoeften is voorzien wordt achterwege gelaten. Beweegreden hiervoor is dat het uitsluitend behoeften met betrekking tot de toegankelijkheid op de intensive care betreft die, zonder de familieleden hiernaar te vragen, rechtstreeks door de onderzoeker beantwoord kunnen worden.

\section{Deelvraagstellingen tweede centrale onderzoeksvraag:}

2a Wat is de invloed van sociaal-demografische factoren op behoeften van familieleden?

Wat is de invloed op behoeften aan informatie?

Wat is de invloed op behoeften aan ondersteuning?

Wat is de invloed op behoeften aan toegankelijkheid?

Wat is de invloed op behoeften in het algemeen (begeleiding)?

Wat is de invloed op de gewenste behoefteverstrekker? 
2b Wat is de invloed van intensive care gelieerde factoren op behoeften van familieleden?

Wat is de invloed op behoeften aan informatie?

Wat is de invloed op behoeften aan ondersteuning?

Wat is de invloed op behoeften aan toegankelijkheid?

Wat is de invloed op behoeften in het algemeen (begeleiding)?

Wat is de invloed op de gewenste behoefteverstrekker?

2c Wat is de invloed van ziektegebonden factoren op behoeften van familieleden?

Wat is de invloed op behoeften aan informatie?

Wat is de invloed op behoeften aan ondersteuning?

Wat is de invloed op behoeften aan toegankelijkheid?

Wat is de invloed op behoeften in het algemeen (begeleiding)?

Wat is de invloed op de gewenste behoefteverstrekker?

2d Wat is de invloed van copingfactoren op behoeften van familieleden?

Wat is de invloed op behoeften aan informatie?

Wat is de invloed op behoeften aan ondersteuning?

Wat is de invloed op behoeften aan toegankelijkheid?

Wat is de invloed op behoeften in het algemeen (begeleiding)?

Wat is de invloed op de gewenste behoefteverstrekker?

Deze deelvragen zijn vooral belangrijk omdat in eerdere studies reeds de invloed van sociaaldemografische factoren en ziektegebonden factoren is aangetoond. Vervolgens wordt invloed van coping factoren verondersteld. De veronderstelde invloed van intensive care gelieerde factoren zijn met name belangrijk omdat zij (mede) bepalend zijn voor de organisatie op de intensive care, immers wanneer aangetoond kan worden dat familieleden behoeften hebben op het gebied van toegankelijkheid, kan de noodzaak ontstaan om intensive gelieerde factoren (b.v. wachttijd op opname en uitstel van de opname) te veranderen ten behoeve van familieleden.

Slechts enkele onderzoekers (Molter, 1979; Daley, 1984) hebben onderzocht wie de wenselijke behoefteverstrekker is in de ogen van de familieleden. Familieleden konden hier uitsluitend de arts of de verpleegkundige benoemen. Hierbij is niet gekeken welke factoren hierop van invloed zijn en of er daadwerkelijk in de behoeften is voorzien. In deze studie wordt, uit praktische overwegingen naast de vraag wie de gewenste behoefteverstrekker is, ook gekeken welke factoren hierop van invloed zijn. Tot slot wordt, vanwege het grote belang voor de familieleden, gekeken of daadwerkelijk in de behoeften is voorzien.

\subsection{Behoeftevariabelen}

In de volgende paragrafen wordt verder ingegaan op de variabelen uit het onderzoeksmodel. De afgelopen jaren zijn met name in de Verenigde Staten van Amerika veel studies gedaan naar behoeften van familieleden op de intensive care. Zoals ook in hoofdstuk 2 wordt beschreven, worden in de meeste studies de behoeften van familieleden op behoefte-item niveau gepresenteerd. Slechts enkele onderzoekers hebben behoefte-items ondergebracht in behoeftecategorieën (Molter, 1979; Daley, 1984; Leske, 1992).

Geen van de onderzoekers hebben het totaal aantal behoefte-items ondergebracht in een algemene behoeftecategorie. Uit alle studies komt duidelijk de behoefte aan kennis (informatie) naar voren, direct gevolgd door steun (ondersteuning, angstreductie). 
Om in deze behoeften te kunnen voorzien worden andere voorwaarden gemeten (nabijheid van de patiënt, kunnen helpen bij de patiënt en persoonlijke behoeften). Deze laatste groep zou, voor de duidelijkheid, aangeduid kunnen worden als "toegankelijkheid". Ook Neuman (1995) noemt, in haar interventieschema, uit iedere behoeftecategorie een aantal behoefteitems, zonder echter deze categorieën specifiek te benoemen.

In deze studie zijn, zoals al eerder is beschreven, de behoefte-items ondergebracht in de drie categorieën die, zoals uit de literatuur naar voren komt, de rode draad vormen in het behoeftepatroon van familieleden (figuur 3.4). Deze behoeftecategorieën zijn "behoeften aan informatie", "behoeften aan ondersteuning" en "behoeften aan toegankelijkheid".

Samen vormen de drie deelgebieden de algemene behoeftecategorie "behoeften aan begeleiding" op de intensive care.

Figuur 3.4 Behoeftecategorieền

\begin{tabular}{|ll|}
\hline $\begin{array}{l}\text { Informatie } \\
\text { Ondersteuning }\end{array}$ & $\rightarrow$ \\
Toegankelijkheid & -
\end{tabular}

Neuman (1995) benadert, in haar interventieschema (hoofdstuk 2), de behoefte van familieleden door deze te relateren aan primaire, secundaire en tertiaire interventies.

Primaire interventies zijn gericht op het behouden van de integriteit van het familiesysteem; secundaire interventies zijn gericht op het gebruiken en versterken van de bestaande familiestructuur en tertiaire interventies zijn gericht op reconstructie van het familiesysteem.

Uitgaande van Neuman's (1995) interventieschema draagt deze studie bij aan verpleegkundige interventies gericht op secundaire preventie (tabel 3.4a). Hierbij wordt verpleegkundige interventie, gericht op behoeften van familieleden, gezien als het voorzien in de behoeften van familieleden en spelen interventies gericht op informatie, ondersteuning en toegankelijkheid, een belangrijke rol. 

intensive care patiënten binnen het Neuman (1995) interventieschema.

\begin{tabular}{|c|c|c|}
\hline Vateriscrtio rat & 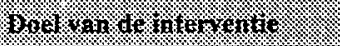 & 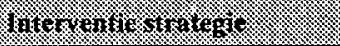 \\
\hline $\begin{array}{l}\text { Primair } \\
\text { Interventie gericht op preventie }\end{array}$ & $\begin{array}{l}\text { Beschermen stabiliteit } \\
\text { familiesysteem } \\
\text { Reduceren stressoren } \\
\text { Gevoeligheid voor stressoren } \\
\text { reduceren }\end{array}$ & $\begin{array}{l}\text { Ontwikkelen van een op } \\
\text { familieleden gerichte } \\
\text { intensive care omgeving } \\
\text {-stimuleren teamplanning } \\
\text {-communicatie } \\
\text {-wachtruime/telefoon } \\
\text {-flexibele bezoekuren } \\
\text { Plan voor familiezorg } \\
\text {-familie gegevens } \\
\text {-ziekte gegevens } \\
\text { Scholing van familieleden en } \\
\text { staf }\end{array}$ \\
\hline 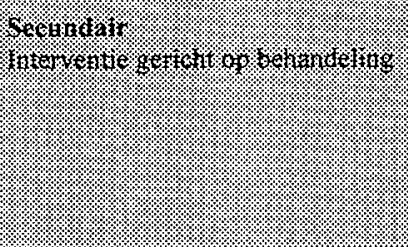 & 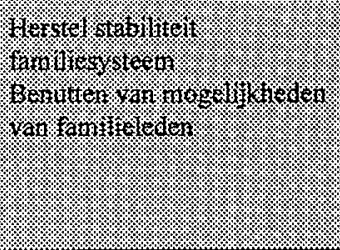 & 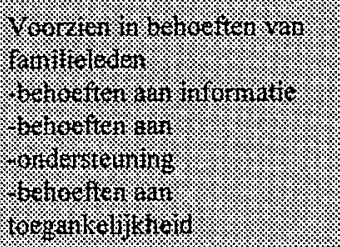 \\
\hline $\begin{array}{l}\text { Tertiair } \\
\text { Interventie gericht op herstel }\end{array}$ & $\begin{array}{l}\text { Handhaven stabiliteit } \\
\text { familiesysteem } \\
\text { Vermijden toename van } \\
\text { reacties op stressoren }\end{array}$ & $\begin{array}{l}\text { Familieleden betrekken bij } \\
\text { de zorg } \\
\text { Handhaven ondersteuning } \\
\text { Handhaven effectieve } \\
\text { communicatie } \\
\text { Scholing gericht op } \\
\text { beëindigen zorgrelatie }\end{array}$ \\
\hline
\end{tabular}

\subsubsection{Behoeften aan informatie}

Zoals uit de literatuurstudie blijkt (hoofdstuk 2) vinden familieleden op de intensive care informatie belangrijk. In de literatuur is de vraag wie er in de behoeften zou moeten voorzien en of er in de behoeften is voorzien tot nu toe verwaarloosd. Enkele onderzoekers hebben familieleden gevraagd naar de wenselijke informatieverstrekker (Molter, 1979; Daley, 1984). Familieleden konden hier uitsluitend de arts of de verpleegkundige benoemen. Geen van de eerdere studies beschrijft of daadwerkelijk in de behoeften is voorzien en door wie dit is gedaan. In deze studie worden zowel behoeften op het gebied van informatie gemeten, er wordt naar de wenselijke informatieverstrekker gevraagd, er wordt gemeten of er daadwerkelijk in de behoeften is voorzien en tot slot wordt gekeken wie er in de behoeften heeft voorzien. Vanuit deze benadering wordt gekeken naar de mogelijkheid familieleden te typeren. Niet alleen vanuit theoretisch oogpunt, maar vooral uit praktisch oogpunt is het belangrijk te weten wat specifieke behoeften zijn op het gebied van informatie en wie dit het beste kan doen. Daarnaast is het vanuit kwalitatief oogpunt belangrijk om te weten of er daadwerkelijk in behoeften van familieleden wordt voorzien en of dit gebeurt door de gewenste persoon. 


\subsubsection{Behoeften aan ondersteuning}

Uit de literatuur blijkt (hoofdstuk 2) dat familieleden van intensive care patiënten minder behoeften hebben aan ondersteuning dan aan informatie. Hierbij dient wel het onderscheid te worden aangebracht tussen ondersteuning van medewerkers op de intensive care en ondersteuning van persoonlijke vrienden of familie van de familieleden. Familieleden geven aan het belangrijk te vinden dat er vrienden in de buurt zijn ter ondersteuning en hulp (Breu en Dracup, 1978; Leske, 1986; O'Neill-Norris en Grove, 1986; Price et al., 1991). Men vindt het echter minder belangrijk om met professionals te spreken over gevoelens als schuld en angst. Ook op het gebied van behoeften aan ondersteuning wordt de vraag naar de wenselijke steungever, evenals de vraag of familieleden daadwerkelijk ondersteuning gekregen hebben, niet beantwoord. Het is om deze reden dan ook, evenals bij de andere behoeftecategorieën, van belang om te weten wat de wensen van de familieleden zijn. Naast de wensen van familieleden is het belangrijk om te weten of er daadwerkelijk in de behoeften van familieleden wordt voorzien, immers wanneer aanleiding bestaat tot veranderingen, respectievelijk verbeteringen met betrekking tot verpleegkundige interventies ten behoeve van familieleden, is het noodzakelijk te weten waarop deze veranderingen gericht moeten zijn. Evenals bij behoeften aan informatie wordt ook, met betrekking tot behoeften aan ondersteuning, gepoogd familieleden te typeren. Ook hier speelt de praktische relevantie een belangrijke rol, omdat alleen een maximaal effect bereikt kan worden wanneer daadwerkelijk steun verleend wordt door de gewenste persoon.

\subsubsection{Behoeften aan toegankelijkheid}

Hoewel geen van de eerder genoemde onderzoekers deze voorwaarden met name benoemt, is het zo dat de toegankelijkheid op de intensive care bepalend is voor het voorzien in bepaalde behoeften (bezoekregelingen, participatie binnen het beleid). Familieleden hechten waarde aan een informatieve brochure (McGregor, Fuller en Lee, 1981; Henneman et al, 1992).

McGregor, Fuller en Lee (1981) toonden aan dat een informatiebrochure een informatieverstrekkend, educatief en drempelverlagend karakter heeft. Overigens werd een dergelijke brochure niet als een eindpunt, maar meer als een stimulans tot discussie gezien.

Ook Henneman et al. (1992) zien de brochure gecombineerd met andere toegankelijkheid gerelateerde behoefte-items zoals open bezockuren. Uit de literatuur komt naar voren dat behoeften als "nabijheid van de patiënt", "kunnen helpen bij de verzorging van patiënt" en "persoonlijke behoeften", met name gericht zijn op voorwaarden om informatie en ondersteuning te krijgen. Om bij de patiënt te kunnen zijn (nabijheid van de patiënt) zullen bezoekregelingen moeten worden aangepast en om te kunnen helpen bij de verzorging van de patiënt zullen familieleden geïnformeerd en ondersteund moeten worden over de wijze waarop en de mogelijkheden waarbinnen dit kan plaatsvinden. Ook voor persoonlijke behoeften, zoals restauratieve voorzieningen en bereikbaarheid zullen voorwaarden aanwezig moeten zijn. In deze studie zullen om bovenstaande argumenten daarom deze behoeften worden ondergebracht in de categorie "toegankelijkheid".

Omdat informatie over de toegankelijkheid gemakkelijk af te leiden is uit de intensive care organisatie, worden deze vragen niet aan de familieleden gesteld. Om dezelfde reden worden behoeften aan toegankelijkheid niet betrokken in de typologie. 


\subsubsection{Behoeften aan begeleiding}

In deze studie worden behoeften aan begeleiding gemeten door de behoefte-items uit de drie afzonderlijke behoeftecategorieën samen te voegen tot een algemene behoeftecategorie ("behoeften aan begeleiding"). Vanuit deze benadering wordt gepoogd het belang van behoeften aan begeleiding in het algemeen een plaats te geven in het verpleegkundig domein. Geen van de eerder genoemde onderzoekers heeft behoeftecategorieën en/of behoefte-items samengevoegd tot een algemene behoeftecategorie zodat uit de literatuur geen resultaten kunnen worden benoemd die samenvoeging theoretisch onderbouwen. In dit onderzoek wordt echter het belang van behoeften aan begeleiding in het algemeen verondersteld. Niet alleen vanuit theoretisch oogpunt, maar vooral vanuit praktisch oogpunt is het belangrijk te weten wat de plaats is van behoeften van familieleden aan begeleiding in het algemeen op de intensive care. Wanneer verpleegkundigen erkennen dat de zorg voor familieleden een verpleegkundige taak is kan, door het belang van behoeften in het algemeen te meten, vastgesteld worden welke prioriteit hieraan gegeven moet worden ten opzichte van andere verpleegkundige taken op de intensive care.

\subsection{Onafhankelijke en overige factoren}

$\mathrm{Na}$ een terugblik op relevante literatuur blijkt dat verschillende factoren een beïnvloedende rol spelen bij behoeften van familieleden op de intensive care. Stillwell (1984) toonde aan dat leeftijd van invloed is op de behoefte om bij de patiënt te kunnen zijn. Andere toonden aan dat zowel de leeftijd van familieleden als de relatie die familieleden met de patiënt hebben invloed heeft op behoeften (Molter, 1979; Stillwell, 1984; Mathis, 1984; Spatt et al., 1986; Norheim, 1989; Bernstein, 1990; Forrester et al., 1990). Ook is verschil tussen mannelijke en vrouwelijke familieleden aangetoond met betrekking tot behoeften (Spatt et al., 1986). Naast de leeftijd, relatie en het geslacht van de familieleden, speelt het feit dat familieleden bekend zijn met de intensive care een beïnvloedende rol. (Molter,1979; Mathis, 1984; Stillwell, 1984; Spatt et al., 1986; Norheim, 1989; Bernstein, 1990; Forrester et al., 1990. Vrijwel alle studies naar behoeften van familieleden, die gemeten zijn met behulp van de C.C.F.N.I. (Molter, 1979), richten zich op de invloed van sociaal-demografische factoren op behoeften. De toetsing van intensive care gelieerde-, ziektegebonden- en copingfactoren heeft slechts op zeer beperkte schaal plaatsgevonden. In deze studie zal, niet alleen vanuit theoretisch oogpunt, maar vooral vanuit praktisch oogpunt, ook gekeken worden naar de eventuele invloed van intensive care gelieerde factoren (factoren die gericht zijn op de intensive care als organisatie), ziektegebonden factoren (factoren die gericht zijn op de patiënt) en copingfactoren (factoren die gericht zijn op het copinggedrag van het familielid). Deze factoren (figuur 3.5) zullen in de volgende paragrafen achtereenvolgens besproken worden. 
Sociaal-demografische factoren Intensive care gelieerde factoren Ziektegebonden factoren Copingfactoren

\subsubsection{Sociaal-demografische factoren}

Zoals in hoofdstuk 2 is beschreven blijkt dat leeftijd, geslacht en relatie van invloed zijn op de behoeften van familieleden op de intensive care. Jongere familieleden hebben meer behoefte om bij de patiënt te zijn dan oudere (Stillwell, 1984). Anderen toonden aan dat de leeftijd van familieleden en de relatie van het familielid met de patiënt, van invloed zijn op de behoeften. Geen van de eerdere studies toonden relaties aan tussen de religie, het woongebied en de sociaal-economische status van de familieleden en behoeften van familieleden. Alleen Leske (1991 \& 1992) toonde relaties aan tussen de bekendheid van de familie met de intensive care en behoeften. In onderhavige studie worden de sociaal-demografische factoren zoals genoemd in figuur 3.5.1. getoetst.

Figuur 3.5.1 Sociaal-demografische factoren

Geslacht
Leeftijd
Relatie tot de patiënt
Religie
Woongebied
Status
Bekendheid met de intensive care

\subsubsection{Intensive care gelieerde factoren}

In geen van de eerdere studies is onderzoek gedaan naar de invloed van intensive care gelieerde factoren op behoeften van familieleden op de intensive care. Omdat een relatie wordt verondersteld tussen de wachttijd op opname op de intensive care, uitstel van de opname, afnametijdstip van de vragenlijst (tijdens opname van patiënt) zijn deze factoren in het onderzoeksmodel opgenomen. Ook naar de invloed van een (eventuele) onplezierige ervaring op de intensive care is niet eerder onderzoek verricht. In figuur 3.5.2 worden de intensive care gelieerde factoren uit deze studie gepresenteerd. 


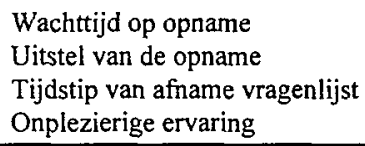

\subsubsection{Ziektegebonden factoren}

Bernstein (1990) vergeleek de behoeften van familieleden van neurochirurgische patiënten met de behoeften van familieleden van hartpatiënten en vond alleen verschil met betrekking tot de behoefte aan informatie. Hartpatiënten bleken meer behoefte aan informatie te hebben.

Mathis (1984) vergeleek de behoeften van familieleden van intensive care patiënten met en zonder hersenletsel op de intensive care. Engli \& Kirsivali-Farmer (1993) vergeleken eveneens de behoeften van familieleden van patiënten met en zonder ernstig hersenletsel op de intensive care. Omdat in bovengenoemde studies verschillen in behoeften werden aangetoond tussen familieleden van beide patiëntengroepen is in het onderzoeksmodel in deze studie de opnameindicatie van de patiënt als beïnvloedende factor opgenomen. In geen van de eerdere studies is gekeken naar de invloed van het karakter van de opname (gepland of spoed) het feit of de patiënt mechanisch beademd wordt en het feit of het een eerste opname betreft.

Omdat hier relaties worden verondersteld zijn de factoren in het model opgenomen (figuur 3.5.3).

Figur 3.5.3 Ziektegebonden factoren

$$
\begin{aligned}
& \text { Opname-indicatie } \\
& \text { Planning van de opname } \\
& \text { Mechanische beademing } \\
& \text { Opnamefrequentie } \\
& \text { Inschatting levensbedreiging }
\end{aligned}
$$

\subsubsection{Copingfactoren}

De bevinding dat de manier van omgaan met belastende situaties en gebeurtenissen van invloed is op het psychisch, fysiek en sociaal welzijn van mensen impliceert dat sommige copingvormen effectiever zijn dan andere, in termen van probleemoplossing.

Effectief copinggedrag betekent dat men door een bepaald copingpatroon gezondheidsklachten voorkomt en/of het welzijn in stand houdt of bevordert, dat men zich in sociaal opzicht prettig voelt en/of zijn gevoel voor zelfwaardering versterkt (Schreurs et al., 1993). 
Coping is een essentieel begrip in de verpleging. Zonder een juist inzicht in de copingfactoren die meespelen in de problemen waaraan familieleden het hoofd moeten bieden, kunnen pogingen hen te helpen hun doel missen of zelfs schadelijk zijn. Voorop staat het besef dat hoe goed iemand de situatie aan kan, bepalend kan zijn voor zijn psychisch welzijn en levensbevrediging (McHaffie, 1993). In dit kader kan men de vraag stellen hoe goed iemand is voorbereid op zijn rol als familielid van een intensive care patiënt en welke copingstijlen familieleden hanteren wanneer hun naaste op de intensive care wordt opgenomen (figuur 3.5.4). In de studie worden copingstrategieën gemeten (bijlage 10) door middel van de 15item versie van de Utrechtse Coping Lijst (Janssen et al., in voorbereiding).

Figuur 3.5.4 Copingfactoren

Actief aanpakken

Sociale steun zoeken

Afwachten en vermijden

Palliatief gedrag

In Neuman's (1995) interventieschema wordt, bij secundaire interventie gericht op de behandeling (figuur 3.4a), de aandacht gevestigd op het benutten van het vermogen van familieleden (benutten van mogelijkheden van familieleden). Met name vanuit deze theorie zou gekeken kunnen worden naar copingstijlen van familieleden op de intensive care. Vanuit deze benadering kunnen mogelijkheden van familieleden geactiveerd worden met als doel de stabiliteit van het familiesysteem te herstellen.

\subsection{Uitgewerkt onderzoeksmodel}

De conclusies van de voorafgaande paragrafen geven aan dat behoeften van familieleden gemeten met de C.C.F.N.I. (Molter, 1979) in de originele formulering, met de specifieke set van variabelen en veronderstelde relaties op basis van Leske's resultaten $(1988,1991,1992)$ en Neuman's (1995) interventieschema, onvoldoende grond geeft voor het doen van uitspraken over behoeften van familieleden. Alvorens een toepassing van Neuman's (1995) interventieschema in een verpleegkundige onderzoekssituatie plaatsvindt, is herformulering en uitbreiding van de C.C.F.N.I. (Molter 1979) evenals het aanpassen van het Neuman's (1995) interventieschema van familieleden noodzakelijk. In figuur 3.6 wordt het uitgewerkte onderzoeksmodel gepresenteerd 
Figuur 3.6 Uitgewerkt onderzoeksmodel

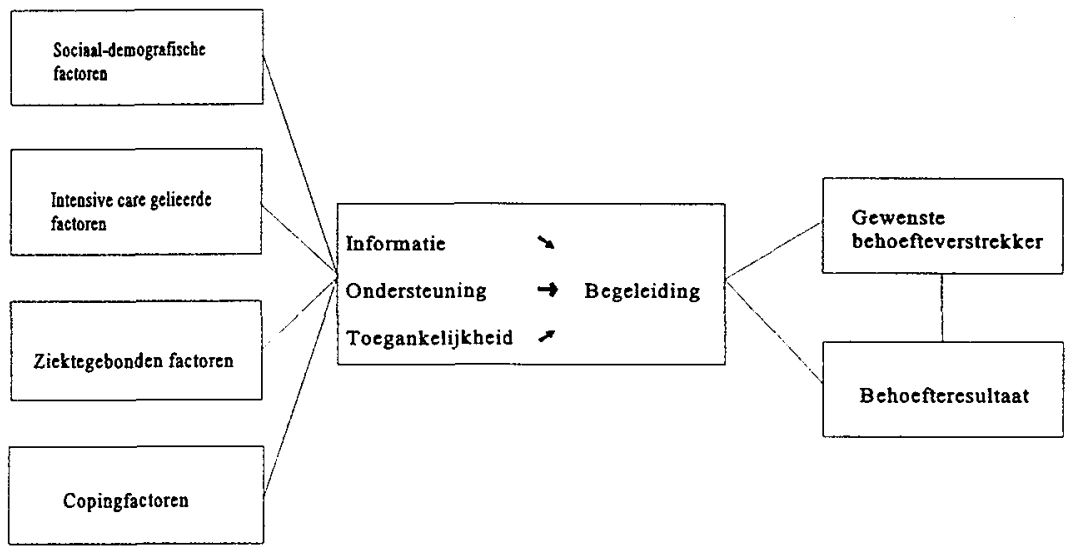

\subsection{Definities van begrippen}

\section{Behoefte}

Over het algemeen wordt het begrip "behoeften van familieleden" in de literatuur niet gedefinieerd. Alleen Leske (1986) omschrijft behoeften als een vereiste die, wanneer hieraan voldaan wordt, een reductie van smart, angst, pijn en uitputting tot gevolg heeft.

Ter Brugge \& de Jong (1994) geven de voorkeur aan een definitie volgens van Dale (1989): "een behoefte is een bewust gemis van iets dat niet of zeer bezwaarlijk ontbeerd kan worden, een verlangen naar". In deze studie wordt uitgegaan van de definitie volgens van Dale (1989) waarbij behoefte gezien wordt als een bewust ervaren gemis.

\section{Intensive Care}

Intensive Care is het voortdurend en geïntegreerd observeren, bewaken en zo nodig ondersteunen of laten overnemen van één of meer vitale functies van een patiënt die in een acute levensbedreigende situatie is gekomen of dreigt te komen, terwijl tevens de oorspronkelijke en eventueel bijkomende ziekten worden behandeld en een goede algemene conditie wordt bevorderd of gehandhaafd (Regeling opleiding aantekening intensive care verpleging, 1994). Definitie vitale functies: processen die zich in het lichaam voltrekken en die van levensbelang zijn, te weten: respiratie, circulatie en temperatuurregulatie.

\section{Intensive Care Afdeling}

Is de plaats waar de zorg die nodig is om vanuit een adequaat reservoir van personele en materiële voorzieningen onmiddellijk levensbedreigende stoornissen van vitale functies te behandelen of te voorkomen als deze stoornissen worden verwacht. 
Daarnaast zijn er voorzieningen voor het toepassen van geavanceerde technieken ter ondersteuning of vervanging van die vitale functies voor langere duur (Intensive Care voorzieningen in Nederlandse ziekenhuizen, Nederlandse Vereniging voor Intensive Care, 1987).

\section{Intensive Care Verpleegkundige}

Is een verpleegkundige $\mathrm{A}$ of $\mathrm{HBO}-\mathrm{V}$ die een opleiding heeft gevolgd die voldoet aan de criteria zoals omschreven in de regeling Opleiding Aantekening Intensive Care Verpleging (Intensive Care voorzieningen in Nederlandse ziekenhuizen, Nederlandse Vereniging voor Intensive Care, 1987).

\section{Gastvrouw}

Is een betaalde, niet verpleegkundige, discipline die belast is met de opvang en begeleiding van familieleden.

\section{Familielid}

Is een persoon van 16 jaar of ouder, verbonden met de patiënt door bloedverwantschap, huwelijk, adoptie of is een voor de patiënt belangrijke persoon (Noordhuis \& Roofihooft , 1991).

\section{Informatie}

Is de inlichtingen of gegevens die aan het familielid gegeven wordt en de manier waarop hij of zij deze ontvangt (Noordhuis \& Roofthooft, 1991).

\section{Ondersteuning}

Is de hulp die het familielid ervaart op sociaal, geestelijk en lichamelijk gebied (Noordhuis \& Roofthooft, 1991).

\section{Toegankelijkheid}

Is de mate waarin de intensive care organisatie open staat voor familieleden, bereid is om te willen aanvaarden, open staat voor bezoek en bereikbaar is (van Dale, 1989).

\section{Begeleiding}

Is het totaal van informatie, ondersteuning en toegankelijkheid.

\section{Hartoperatiepatiënt}

Is een volwassen patiënt waarbij een openhartoperatie heeft plaatsgevonden en waarbij intensive care geïndiceerd is.

\section{Overige intensive care patiënt}

Is een volwassen patiënt met een aandoening waarbij intensive care geïndiceerd is en waar het niet een openhartoperatie of een neurochirurgische indicatie betreft. 


\subsection{Onderzoeksdesign}

Deze kwantitatieve beschrijvende studie heeft het karakter van een survey onderzoek (Polit \& Hungler, 1991) waarbij behoeften gemeten worden bij een groep (familieleden van intensive care patiënten). Omdat groepen mensen constant aan veranderingen onderhevig zijn en omdat behoeften door de tijd heen kunnen veranderen kunnen verschillende technieken en/of benaderingswijzen gehanteerd worden bij onderzoek naar behoeften. Voorbeeld hiervan is behoefteonderzoek voor en na een service programma.

In deze studie worden eerst de behoeften van familieleden van intensive care gemeten met een gestructureerde, aan de Nederlandse situatie aangepaste, vragenlijst die gebaseerd is op de door Daley (1984) gehanteerde Critical Care Family Needs Inventory van Molter (1979) (bijlage 1). Op deze wijze wordt gepoogd een antwoord te krijgen op de behoeften die familieleden van intensive care patiënten hebben in het algemeen en in het bijzonder aan informatie, ondersteuning en toegankelijkheid. Er wordt invloed verondersteld van de opname-indicatie van de patiënt op behoeften van familieleden. Om deze reden is de onderzoeksgroep verdeeld in twee onderzoeksgroepen (familieleden van hartoperatiepatiënten en familieleden van overige intensive care patiënten). Familieleden van neurochirurgische intensive care patiënten zijn uitgesloten van deelname aan het onderzoek.

Ten tweede wordt, middels een algemene gestructureerde vragenlijst (bijlage 9), gekeken naar de invloed van sociaal-demografische-, ziektegebonden- en intensive care gelieerde factoren op behoeften van familieleden.

Ten derde wordt, middels de 15-item versie van de Utrechtse Coping Lijst (Janssen et al. in voorbereiding), gekeken naar de invloed van copingstrategieën op behoeften van familieleden (bijlage 10).

\subsection{Samenvatting}

In dit hoofdstuk is aandacht besteed aan het interventieschema van Neuman (1995). Er is een overzicht gegeven van de ontwikkelingen op het gebied van behoeften van familieleden, gemeten met behulp van de C.C.F.N.I. (Molter, 1979) op de intensive care. Uit verschillende studies komt naar voren dat behoeften van familieleden beïnvloed worden door onafhankelijke en overige factoren. Het in dit hoofdstuk gepresenteerde onderzoeksmodel en de daaraan ten grond liggende onderzoeksvragen staan centraal in de analyses. Het uitgewerkte onderzoeksmodel (figuur 3.6) zal in hoofdstuk 4 verder worden geoperationaliseerd. De centrale onderzoeksvragen hebben betrekking op behoeften van familieleden en de factoren die hierop van invloed zijn. De (deel)vraagstellingen geven antwoord op de vraag wie de gewenste behoefteverstrekker is en de vragen of er daadwerkelijk in de behoefte is voorzien en door wie. 


\section{POPULATIE EN METHODEN}

\subsection{Inleiding}

De bevindingen uit de voorafgaande hoofdstukken leiden tot de conclusie dat de resultaten (categorisering van behoefte-items en aangetoonde invloed van sociaal-demografische- en overige factoren) uit de studies van Leske $(1988,1991,1992)$ toegepast binnen het interventieschema van Neuman (1995) een geschikt uitgangspunt vormen voor de concrete invulling van het theoretisch kader van deze studie (hoofdstuk 3). Tevens blijkt dat een aantal wijzigingen de bruikbaarheid van het model kunnen vergroten. De herformulering van Neuman's (1995) interventieschema tot een toepasbaar onderzoeksmodel voor de (intensive care) verpleging bestaat uit de toevoeging van nieuwe factoren en uitbreiding van veronderstelde relaties. De keuze voor nieuwe factoren is enerzijds gebaseerd op theoretische overwegingen en anderzijds op de specifieke kenmerken van de intensive care en de verpleegkundige werksituatie op de intensive care. In dit hoofdstuk wordt allereerst een beschrijving gegeven van de setting van het onderzoek, de onderzoekspopulatie, de respons en de methode. Vervolgens wordt het meetinstrument besproken, waarbij de variabelen afzonderlijk worden toegelicht.

\subsection{De setting van het onderzoek}

Het hoofdonderzoek heeft plaatsgevonden in twee ziekenhuizen in de regio Utrecht die een bovenregionale functie hebben op het gebied van intensive care. Door middel van introductiebrieven (bijlage 2) aan de ziekenhuisdirecties, de medisch ethische commissie van beide ziekenhuizen, de betrokken specialisten (maatschappen) en de hoofdverpleegkundigen en medewerkers van de intensive care afdelingen, is getracht de ziekenhuizen te motiveren voor deelname aan het onderzoek. Beide ziekenhuizen gaven aan geïnteresseerd te zijn in het onderzoek.

Tabel 4.2 geeft een overzicht van de grootte van de deelnemende ziekenhuizen (uitgedrukt in het aantal erkende ziekenhuisbedden; NZI, 1994).

Tabel 4.2 Overzicht deelnemende ziekenhuizen (NZI, 1994)

\begin{tabular}{|c|c|c|}
\hline 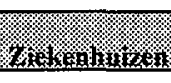 & 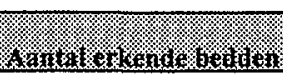 & 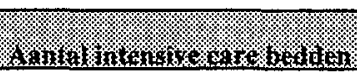 \\
\hline $\mathrm{A}$ & 584 & 37 \\
\hline B & 857 & 38 \\
\hline
\end{tabular}

In beide ziekenhuizen vond vervolgens een gesprek plaats met de afdelingshoofden, waarna de onderzoeksopzet gepresenteerd werd in een werkbespreking. In de werkbesprekingen werd ingegaan op vragen omtrent het onderzoek en werd door de onderzoeker een nadere toelichting gegeven op de eerder gestuurde samenvatting van het doel en de opzet van het onderzoek. Ook werd de tijdsplanning van het onderzoek besproken. 
Tenslotte werden afspraken gemaakt met betrekking tot de inclusiecriteria van de deelnemende intensive care afdelingen (twee thoraxchirurgische intensive care afdelingen en twee algemene intensive care afdelingen waarbij neurochirurgische patiënten werden uitgesloten). De inclusiecriteria voor de familieleden waren: (1) persoon van zestien jaar of ouder en (2) verbonden met de patiënt door bloedverwantschap, huwelijk, adoptie of is een voor de patiënt belangrijke persoon). Voor de patiënt gold (1) persoon die, niet langer dan 72 uur, opgenomen is op één van de vier bovengenoemde intensive care afdelingen.

Gestreefd werd naar een gelijke verdeling (tabel 4.2a) van respondenten op de vier bovengenoemde intensive cares ( 50 familieleden per intensive care), zodat twee groepen familieleden ontstonden ( 100 familieleden van hartoperatiepatiënten en 100 familieleden van overige intensive care patiënten).

Tabel 4.2a Overzicht respondenten

\begin{tabular}{|c|c|c|}
\hline (x) & 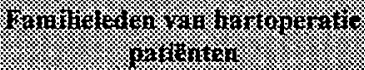 & 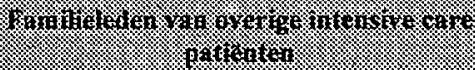 \\
\hline $\begin{array}{l}1 \text { (ziekenhuis A) } \\
2 \text { (ziekenhuis B) } \\
\text { Totaal }\end{array}$ & $\begin{array}{r}50 \\
50 \\
100\end{array}$ & $\begin{array}{r}50 \\
50 \\
100\end{array}$ \\
\hline
\end{tabular}

Door de dienstdoende intensive care verpleegkundige of door de gastvrouw werd aan de, voor dit onderzoek in aanmerking komende, familieleden gevraagd of zij aan het onderzoek deel wilden nemen.

\subsection{De onderzoekspopulatie}

In totaal zijn 229 familieleden, uit twee ziekenhuizen op vier intensive care afdelingen, gevraagd deel te nemen aan het onderzoek. Vanaf een bepaald moment zijn familieleden dagelijks op de intensive care benaderd tijdens bezoekuren tot het totaal van 206 familieleden bereikt was. De vragenlijst werd, in het bijzijn van de onderzoekers aan de familieleden voorgelegd. Nadat de vragen door de onderzoekers aan de familieleden gesteld waren en de familieleden de vragen (mee) gelezen hadden werden de antwoorden genoteerd face-to-face interview methode, Emans, 1986).

In het totaal verklaarden 206 familieleden zich bereid tot deelname. In 23 gevallen weigerden familieleden hun medewerking. Hiervoor werden de volgende redenen gegeven:

1. De patiënt bevond zich in een kritieke toestand en het familielid voelde zich niet in staat de vragenlijst in te vullen (10).

2. Het familielid gaf aan geen tijd te hebben om de vragenlijst in te vullen. Hij of zij was van vervoer door anderen afhankelijk en kon niet langer op de intensive care blijven (7).

3. Het familielid zag het nut van het onderzoek niet in (6). 
De totale groep respondenten is opgebouwd uit 106 (6 geïnterviewde familieleden zijn toegevoegd aan de groep familieleden van algemene intensive care patiënten ten gevolge van oversampling) familieleden van algemene intensive care patiënten (met uitzondering van neurochirurgische intensive care patiënten) en 100 familieleden van hartoperatiepatiënten. Het onderzoek heeft plaatsgevonden op vier intensive care afdelingen in twee ziekenhuizen, te weten het Academisch Ziekenhuis Utrecht en het St. Antonius Ziekenhuis Nieuwegein. Vanuit het Academisch Ziekenhuis Utrecht zijn 50 familieleden van hartoperatiepatiënten op de hartchirurgische intensive care en 50 familieleden van algemene intensive care patiënten op de algemene intensive care (heelkunde) in het onderzoek opgenomen.

Vanuit het St. Antonius Ziekenhuis zijn 50 familieleden van hartoperatiepatiënten op de intensive care en 56 familieleden van algemene intensive care patiënten op de intensive care in het onderzoek opgenomen. In het St. Antonius Ziekenhuis is, in tegenstelling tot het Academisch Ziekenhuis Utrecht, de intensive care niet onderverdeeld op basis van specifieke patiëntendoelgroepen. De onderzoekspopulatie bestaat uit 141 vrouwen $(68.4 \%)$ en 65 mannen (31.6\%) en varieert in leeftijd van 21 tot 82 jaar met een gemiddelde leeftijd van 51.1 jaar. Alle respondenten zijn woonachtig in Nederland.

\subsection{Respons}

Het responspercentage voor de totale onderzoekspopulatie is $90 \%$ (tabel 4.4).

De totale onderzoeksgroep is opgebouwd uit 106 familieleden van algemene intensive care patiënten en 100 familieleden van hartoperatiepatiënten op de intensive care.

Tabel 4.4 Respons van familieleden van intensive care patiënten.

\begin{tabular}{|c|c|c|}
\hline \multicolumn{2}{|c|}{ 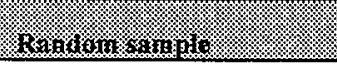 } & arssting \\
\hline Harten & $109(100 \%)$ & $100(92 \%)$ \\
\hline Overigen & $120(100 \%)$ & $106(88 \%)$ \\
\hline Totaal & $229(100 \%)$ & $206(90 \%)$ \\
\hline
\end{tabular}

\subsection{Methode van onderzoek}

Om de verschillende variabelen uit het onderzoeksmodel te meten, is gebruik gemaakt van een mondelinge (algemene vragen en behoeftevragen) en een schriftelijke (coping) interviewmethode met behulp van drie vragenlijsten (algemene vragenlijst, behoeftelijst en copinglijst).

De interviews vonden plaats in de periode van oktober 1992 tot mei 1993 op volstrekt willekeurige dagen. Op deze dagen werd eerst een inventarisatie gemaakt van het aantal patiënten dat nog niet langer dan 72 uur op de intensive care was opgenomen. Tijdens de bezoekuren werden familieleden van deze patiënten benaderd. Er werd een korte uitleg gegeven van het doel van het onderzoek, de voorwaarden (vrijwilligheid en anonimiteit) en de wijze waarop de vragenlijst zou worden afgenomen. Daarna werd gevraagd of het familielid zijn of haar medewerking wilde verlenen. 
Bij een positief resultaat werd de vragenlijst ofwel direct afgenomen, of er werd een afspraak gemaakt voor de volgende dag (mits de 72 uur hierdoor niet werden overschreden).

In een speciaal voor dit doel beschikbaar gestelde ruimte werd het interview afgenomen. De onderzoeker stelde de vragen, gaf zonodig korte uitleg als de vraag niet werd begrepen en vulde de antwoorden in. De familieleden vulden zelf de verkorte Utrechtse Coping Lijst (Janssen et al. in voorbereiding) in. Het interview had een gemiddelde duur van 45 minuten. Tabel 4.5 toont een overzicht van de perioden waarin de vragenlijsten werden afgenomen.

Tabel 4.5 Perioden waarin de vragenlijsten afgenomen zijn.

\begin{tabular}{|c|c|c|c|}
\hline 18. & $8 x_{4}$ & 6. & 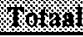 \\
\hline $0-24$ utr & 18 & 16 & 34 \\
\hline $24-48$ uur & 63 & 45 & 108 \\
\hline $48-72$ uur & 19 & 45 & 64 \\
\hline Totaal & 100 & 106 & 206 \\
\hline
\end{tabular}

Nadat de familieleden toestemming gegeven hadden aan de dienstdoende intensive care verpleegkundige of de gastvrouw voor deelname aan het onderzoek, werd een afspraak gemaakt, meestal voor de volgende dag, met de onderzoeker voor het afnemen van de vragenlijst.

De vragenlijsten werden in het totaal door drie studenten (doctoraalstudenten van de Universiteit Maastricht, afstudeerrichting Verplegingswetenschap) en de onderzoeker afgenomen. Om tot afstemming te komen met betrekking tot het uniform afnemen van de vragenlijst (het voorkomen van interviewers-bias) zijn eerst afspraken gemaakt (de onderzoekers lazen alleen de vragen voor, eventuele verduidelijking van de vragen vond op éénduidige wijze plaats, er werden geen voorbeelden gegeven) waarna verschillende oefensessies plaatsvonden (assistent-onderzoekers oefenden op elkaar onder supervisie van de onderzoeker). Tot slot werden de eerste familieleden door twee onderzoekers geïnterviewd, waarbij de onderzoekers beurtelings interviewden en toekeken.

$\mathrm{Na}$ het mondeling afnemen van de vragenlijst werd het familielid gevraagd de copinglijst zelfstandig in te vullen. Familieleden konden zelf het tijdstip voor het invullen van de vragenlijst bepalen. De plaats waar de vragenlijst werd afgenomen, werd bepaald door de onderzoeker. De tijd die benodigd was voor het invullen van de totale vragenlijst bedroeg gemiddeld 45 minuten. De ingevulde vragenlijsten werden door de onderzoeker verzameld. 


\subsubsection{De pilotstudie}

Alvorens te starten met onderhavige studie is een pilotstudie (Roofthooft \& Noordhuis, 1991) uitgevoerd. Het doel van deze pilotstudy was (1) het aanpassen aan de Nederlandse situatie en het valideren van de in het Nederlands vertaalde vragenlijst van Daley, (1984) en (2) het meten van de afhankelijke variabele (behoeften van familieleden) in de Nederlandse setting. De vragenlijst van Daley (1984) is gebaseerd op de C.C.F.N.I. (Critical Care Family Needs Inventory; Molter, 1979). Resultaten uit de onderzoeken van Hampe, (1975) Gardner en Steward, (1978) en persoonlijke (intensive care) verpleegkundige ervaring van Daley (1984) resulteerde in een vragenlijst bestaande uit 46 behoefte-items (Daley, 1984) die zijn ondergebracht in zes behoeftecategorieën (zie tabel 4.5.1).

Tabel 4.5.1 The six major categories of needs, Daley (1984).

\begin{tabular}{|c|c|c|}
\hline \% & \multicolumn{2}{|c|}{ 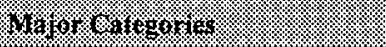 } \\
\hline 9 & I. & Personal needs \\
\hline 7 & 2. & Need to decrease anxiety \\
\hline 10 & 3. & Need for support and ventilation \\
\hline 7 & 4. & Need to be with the patient \\
\hline 11 & 5. & Need for information \\
\hline 2 & 6. & Need to be helpful \\
\hline
\end{tabular}

Om een indruk te krijgen welke vragen per categorie door Daley (1984) gesteld zijn, wordt in tabel 4.5.1a per categorie één voorbeeld getoond.

Tabel 4.5.1a

\begin{tabular}{|c|c|}
\hline 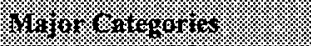 & 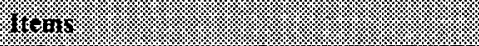 \\
\hline $\begin{array}{l}\text { Personal needs } \\
\text { Need to decrease anxiety } \\
\text { Need for support and ventilation } \\
\text { Need to be with the patient } \\
\text { Need for information } \\
\text { Need to be helpful }\end{array}$ & $\begin{array}{l}\text { To have coffee available } \\
\text { To be told about transfer plans in time } \\
\text { To talk to someone about my feelings } \\
\text { To be able to be with my familymember in the ICU } \\
\text { To know what is wrong with my familymember } \\
\text { To help with the care of my familymember }\end{array}$ \\
\hline
\end{tabular}

\subsubsection{De vragenlijst van de pilotstudie}

Na vertaling van de vragenlijst (bijlage 4), is deze aangepast aan de Nederlandse situatie. Op grond van vier open interviews met een hoofdverpleegkundige van de intensive care (bijlage 5), het hoofd van de gastvrouwen (een discipline dat belast is met het geven van algemene informatie aan familieleden op de intensive care; bijlage $5 b$ ), gastgezinnen (gezinnen die in de directe omgeving van het ziekenhuis wonen en overnachtingsmogelijkheden bieden aan familieleden van intensive care patiënten tegen een kleine financiële vergoeding; bijlage 5a) en vertegenwoordigers uit de klachtencommissie van het ziekenhuis (bijlage 5), is de vragenlijst aangepast aan de Nederlandse situatie. 
De doel- en vraagstelling van deze interviewmethode was het krijgen van inzicht in de organisatie, de infrastructuur en de patiëntenpopulatie van de Nederlandse intensive care setting, teneinde de vragenlijst hierop af te stemmen. Uit de interviews bleek dat, in Nederland, de nadruk zou moeten komen te liggen op vijf dimensies ten aanzien van behoeften van familieleden. Familieleden van intensive care patiënten, zo adviseerden de deskundigen, zijn gericht op communicatie, informatie, individuele behoeften, ondersteuning en toegankelijkheid.

Hierna is de vragenlijst voorgelegd aan tien experts volgens de Delphi-methode (Polit \& Hungler, 1991) te weten zes intensive care verpleegkundigen, twee gastvrouwen en twee leden uit gastgezinnen met de vraag de vragenlijst op validiteit te testen (face validity). Van de 46 behoefte-items uit de lijst van Daley (I984) werden 14 behoefte-items verwijderd (tabel 4.5.1.1) en 32 behoefte- items overgenomen, waarvan 1 geherformuleerd, namelijk "de behoefte aan de aanwezigheid van een verpleegkundige tijdens het bezoek aan de patiënt" werd "de behoefte aan de aanwezigheid van een verpleegkundige tijdens het eerste bezoek aan de patiënt") en 1 gesplitst in 2 behoefte-items, namelijk "de behoefte aan informatie over veranderingen in de conditie van de patiënt werd a: behoefte aan informatie over verslechtering van de patiënt en b: behoefte aan informatie over vorderingen van de patiënt). Dit resulteerde in de vragenlijst bestaande uit 33 behoefteitems.

Tabel 4.5.1.1 toont de 14 verwijderde behoefte-items met de daaraan ten grondslag liggende argumentatie uit de lijst van Daley (1984).

Tabel 4.5.1.1 Overzicht verwijderde behoefte-items uit de lijst van Daley (1984).

\begin{tabular}{|c|c|c|c|}
\hline \multicolumn{2}{|c|}{ 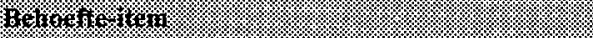 } & \multicolumn{2}{|c|}{ (4) } \\
\hline 1. & Behoefte om in de buurt van de ICU te zijn & 1. & $\begin{array}{l}\text { Kan worden afgeleid van andere vragen (behoefte aan } \\
\text { een ruimte om in te kunnen verblijven) }\end{array}$ \\
\hline 2. & $\begin{array}{l}\text { Behoefte aan iemand die uitlegt hoe ik met de } \\
\text { verzorging van de patient kan helpen }\end{array}$ & 2. & Kan worden afgeleid uit B-vragen* \\
\hline 3. & $\begin{array}{l}\text { Steeds verzekerd worden dat het goed gaat met de } \\
\text { patient }\end{array}$ & 3. & Niet resle vraag bevonden \\
\hline 4. & Geaccepteerd voelen door het personeel & 4. & Kan worden afgeleid van vragen over ondersteuning \\
\hline 5. & $\begin{array}{l}\text { De mogelijkheid hebben dat de patient op een kamer } \\
\text { alleen verpleegd kan worden }\end{array}$ & 5. & Mogelijkheid die niet bestaat op verzoek van de familie \\
\hline 6. & Hułp krijgen bij financiele zaken & 6. & $\begin{array}{l}\text { Niet relevant in Nederland (collectieve ziektekosten- } \\
\text { verzekering) }\end{array}$ \\
\hline 7. & $\begin{array}{l}\text { De mogelijkheid hebben dat mijn vragen beantwoord } \\
\text { worden }\end{array}$ & 7. & $\begin{array}{l}\text { Kan worden afgeleid van andere vragen (dat vragen } \\
\text { eerlijk beantwoord worden) }\end{array}$ \\
\hline 8. & Met de dokter kunnen praten & 8. & Kan worden afgeleid uit B-vragen \\
\hline 9. & Met de verpleegkundige kunnen praten & 9. & Kan worden afgeleid uit B-vragen \\
\hline 10. & $\begin{array}{l}\text { Geinformeerd worden over veranderingen die zich } \\
\text { voordoen bij de patiënt }\end{array}$ & 10. & $\begin{array}{l}\text { Is geherformuleerd in vordering en verslechtering van de } \\
\text { patient ( } 2 \text { vragen) }\end{array}$ \\
\hline 11. & $\begin{array}{l}\text { Antwoorden kunnen krijgen van verschillende } \\
\text { personeelsleden }\end{array}$ & 11. & Kan worden afgeleid uit B-vragen \\
\hline 12. & Kwalificaties kennen van het personeel & 12. & Niet relevant bevonden \\
\hline 13. & Verteld worden dat er hoop is & 13. & Kan worden afgeleid uit andere vragen \\
\hline 14. & $\begin{array}{l}\text { Verzekerd worden dat de best mogelijke zorg verleend } \\
\text { wordt }\end{array}$ & 14. & Kan worden afgeleid uit andere vragen \\
\hline
\end{tabular}


De concept vragenlijst, met de op grond van de suggesties verwijderde en gewijzigde items, is nogmaals voorgelegd aan drie (inhouds)deskundigen van de vakgroep Verplegingswetenschap Maastricht. Deze beoordeelden de items en voegden 6 behoefte-items toe (tabel 4.5.1.1a). Na overleg met de inhoudsdeskundigen is de definitieve, uit 39 behoefte-items bestaande en in 5 behoeftecategorieën ondergebrachte, vragenlijst vastgesteld (Noordhuis \& Roofthooft, 1991).

Tabel 4.5.1.1a Toegevoegde behoefte-items

\begin{tabular}{|c|c|}
\hline 1. & $\begin{array}{l}\text { Behoefte aan informatie over de gang van zaken op de intensive care voordat ik mijn familie- } \\
\text { lid voor de eerste keer bezoek }\end{array}$ \\
\hline 2. & Behoefte dat er tijd genomen wordt om mijn vragen te beantwoorden \\
\hline 3. & Behoefte aan een contactpersoon op de intensive care \\
\hline 4. & Behoefte aan een vast tijdstip voor het stellen van vragen \\
\hline 5. & Behoefte om direct na opname van de patiënt op bezoek te kunnen \\
\hline 6. & Behoefte aan het zonodig kunnen aanpassen van de bezoekuren \\
\hline
\end{tabular}

Per behoefte-item zijn vier vragen (A, B, C en D-vragen) gesteld (tabel 4.5.1.1b).

Voor de A-vragen, die het belang van een behoefte meten, is gebruik gemaakt van een 4-punt Likertschaal waarbij de antwoordmogelijkheden oplopen van (1) helemaal niet mee eens tot (4) helemaal mee eens. De B-vragen meten welke persoon er in de behoefte zou moeten voorzien (verpleegkundige, arts, gastvrouw, anderen), de C-vragen meten of er in de behoefte is voorzien ( $\mathrm{ja}$ of nee) en de D-vragen meten, als er in de behoefte is voorzien, door wie er in de behoefte is voorzien (verpleegkundige, arts, gastvrouw, anderen).

Naast de vragen met betrekking tot behoeften van familieleden zijn sociaal-demografische vragen gesteld (zie tabel 4.5.1.1b).

Tabel 4.5.1.1b Opbouw vragenlijst pilotstudy

\begin{tabular}{|c|c|}
\hline Behoeftevragen & $\begin{array}{l}\text { A-vragen meten het belang van de behoefte } \\
\text { B-vragen meten wie in de behoefte moet voorzien } \\
\text { C-vragen meten of er in de behoefte is voorzien } \\
\text { D-vragen meten wie er in de behoefte heeft voorzien }\end{array}$ \\
\hline Sociaal demografische vragen & Geslacht en leeftijd \\
\hline
\end{tabular}




\subsubsection{De onderzoekspopulatie van de pilotstudy}

De vragenlijsten zijn, na toestemming van de ziekenhuisdirectie, het intensive care management en het geven van informatie over het doel van de pilotstudy, willekeurig uitgereikt aan 56 van de 100 intensive care verpleegkundigen die werkzaam zijn binnen de intensive care van het St. Antonius Ziekenhuis in Nieuwegein. Opzettelijk is gekozen voor verpleegkundigen in plaats van familieleden. Aan dit besluit lag de tijdsdruk waaronder de onderzoekers gewerkt hebben ten grondslag.

Het St. Antonius Ziekenhuis Nieuwegein is een topklinisch ziekenhuis met een "artikel 18-erkenning" (een door de overheid formeel goedgekeurd en gelimiteerd aantal open-hartoperaties, welke gefinancierd worden door de ziektekostenverzekeraars) op het gebied van open-hartchirurgie. De intensive care telt 37 bedden en is onderverdeeld in twee units. Naast hartchirurgische patiënten worden ook algemene intensive care patiënten behandeld. De informatie over het doel van de pilotstudy werd gegeven tijdens werkbesprekingen waar de onderzoeker zowel uitleg gaf als vragen beantwoordde.

Alvorens de vragenlijst in te vullen werd de verpleegkundigen gevraagd zich, met behulp van een casus (bijlage 6) in te leven in de rol van familielid (naaste) op de intensive care.

Hierna werd door de onderzoeker, tijdens werkbesprekingen, instructie gegeven over het invullen van de vragenlijst. Omdat de verpleegkundigen de $\mathrm{C}$ - en D-vragen niet konden invullen (het betrof een fictieve situatie) werden deze achterwege gelaten.

\subsubsection{Respons}

Drie van de 56 vragenlijsten zijn, omdat ze teveel missing values vertoonden en daardoor verstoring in de analyses veroorzaakten, verwijderd uit de pilotstudy. De uiteindelijke respons bedroeg $95 \%$. Alle respondenten waren verpleegkundigen in het bezit van het diploma intensive care verpleegkundige. De leeftijd van de respondenten varieerde van 23 tot 54 jaar. De gemiddelde leeftijd was 32 jaar. Zowel vrouwelijke (70.9\%) als mannelijke (29.1\%) verpleegkundigen hebben deel uitgemaakt van de pilotstudy.

\subsubsection{Resultaat van de pilotstudie}

Het resultaat uit de pilotstudie, ontleend aan (1) twee Delphi-ronden, (2) verwijderde items op grond van onvoldoende verklaarde variantie waarbij een grens van $85 \%$ is gehanteerd en (3) 1e en 2e orde factoranalyses, is een vragenlijst die uit 17 behoefte-items bestaat (tabel 4.5.1.4). Ondanks het feit dat Noordhuis en Roofthooft (1991) zowel de algemene behoeftecategorie "begeleiding" als de driedeling "behoeften aan informatie, ondersteuning en toegankelijkheid" niet hebben toegepast, wordt uit de gepresenteerde behoefte-items (tabel 4.5.1.4) duidelijk dat ook hieruit de driedeling kan worden afgeleid, omdat alle behoefteitems gemakkelijk zijn te herleiden tot behoeften op het gebied van informatic, ondersteuning of toegankelijkheid. 
Tabel 4.5.1.4 De 17-itemlijst van de pilotstudie (Noordhuis \& Roofthooft, 1991).

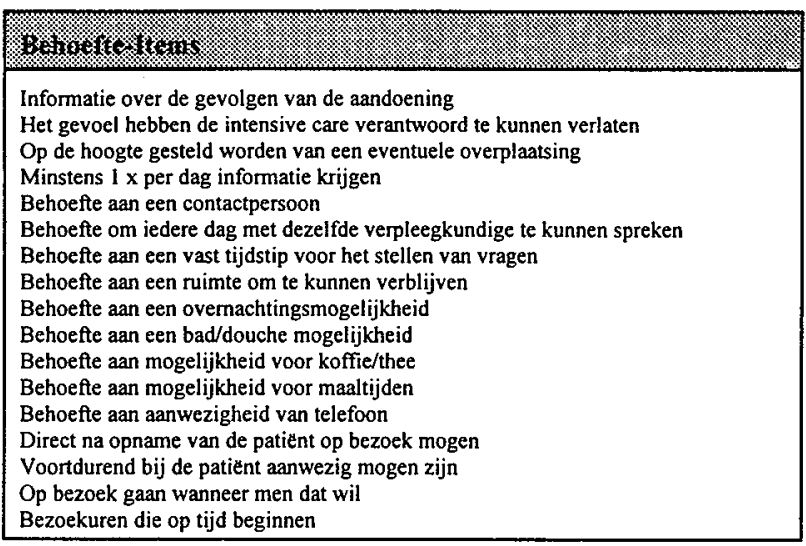

\subsection{Het meetinstrument van het hoofdonderzoek}

Het meetinstrument bestaat uit drie vragenlijsten: (1) de algemene lijst, waarin sociaaldemografische-, ziektegebonden- en intensive care gelieerde factoren gemeten worden (2) de behoeftelijst en (3) de 15-item Utrechtse Coping Lijst (Janssen et al, in voorbereiding).

Behoeften zijn gemeten met behulp van een Nederlandstalige bewerking (Kaljouw, Noordhuis en Roofthooft, 1991) van de vragenlijst van Daley (1984) gebaseerd op de Critical Care Family Needs Inventory van Molter (1979) die, nadat de pilotstudy is uitgevoerd, nogmaals door een panel van experts (Vakgroep Verplegingswetenschap Maastricht) is getoetst en gewijzigd. Aanleiding hiervoor was dat de vragenlijst in de pilotstudie uitsluitend door intensive care verpleegkundigen is ingevuld en hierdoor de kans op "beroepsblindheid" aanwezig werd geacht. Van de 17 items (Noordhuis en Roofihooft, 1991, tabel 4.5.1.4) werden 6 items (behoefte aan een ruimte om in te kunnen verblijven, behoefte aan overnachtingsmogelijkheid, douchemogelijkheid, gebruik van koffie en thee, gebruik van maaltijden en gebruik van telefoon) samengevoegd tot 2 items (behoefte aan overnachtingsmogelijkheid en behoefte aan koffie/thee). Hierna werden 11 behoefte-items toegevoegd (tabel 4.6). De uitbreiding van de vragenlijst is enerzijds gebaseerd op theoretische overwegingen (behoefte-item $1 \mathrm{t} / \mathrm{m}$ 7) en anderzijds op praktische ervaring van het panel van experts (behoefte-item $8 \mathrm{t} / \mathrm{m} \mathrm{11}$ ). De theoretische overwegingen zijn ontleend uit het Neuman Systems Model (Neuman, 1995) dat, met betrekking tot behoeften van familieleden op de intensive care, gebaseerd is op resultaten van de studies van Hickey (1990) en Leske (1991 \& 1992). 


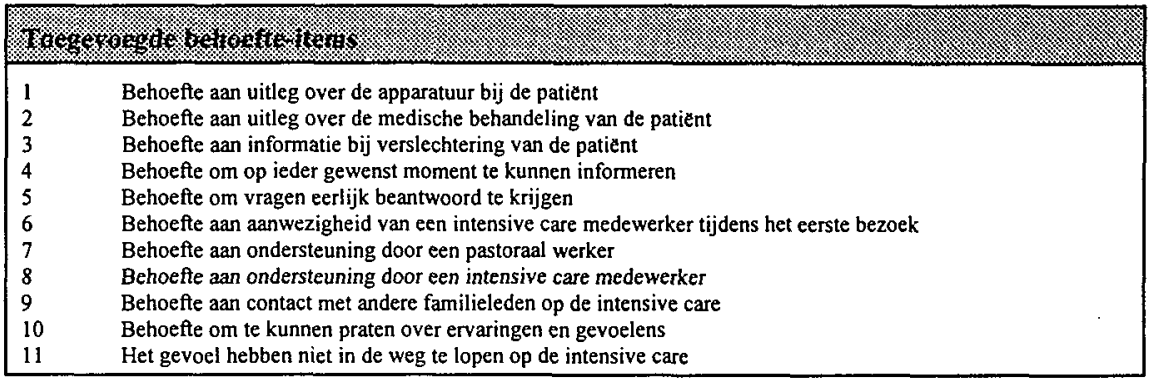

De 24 behoefte-items (bijlage 7) zijn, in eerste instantie, ondergebracht in vier behoeftecategorieën ("behoeften aan informatie, communicatie, ondersteuning en toegankelijkheid"). Voor de uitbreiding van het aantal behoeftecategorieën met de categorie "communicatie" is gekozen om een zo gelijk mogelijke verdeling van het aantal behoefte-items per categorie te krijgen. Tenslotte is gebruik gemaakt van de verkorte Utrechtse Coping Lijst (U.C.L.) van Janssen et al. (in voorbereiding) om de copingstijl van familieleden op de intensive care te meten.

Tabel 4.6a toont een overzicht van het gebruikte meetinstrument en de meetmethode. Het meetinstrument bestaat uit 10 sociaal-demografische-, 6 ziektegebonden-, 6 intensive care gelieerde-, 24 behoefte- en 15 copingvariabelen. De 24 behoefte-items zijn ondergebracht in 4 behoeftecategorieën. Na iedere behoeftecategorie is aan de respondent gevraagd een rapportcijfer te geven dat de mate van tevredenheid aangeeft over de betreffende behoeftecategorie.

Per behoefte-item zijn vier vragen gesteld (tabel 4.5.1.1b). De A-vraag meet op een 4-puntLikertschaal het belang van de behoefte, de B-vraag meet wie er in de behoefte moet voorzien, de C-vraag meet of er in de behoefte is voorzien en de $\mathrm{D}$-vraag meet wie er in de behoefte heeft voorzien. Omdat bij een aantal behoefte-items de antwoorden op de B-, C- en Dvragen van te voren bekend of niet te beantwoorden zijn, (bijvoorbeeld bij het meten van de behoefte aan een pastoraal werker wordt niet gevraagd wie er in deze behoefte moet voorzien) of C- en D-vragen niet aan de orde zijn (bijvoorbeeld bij de vraag of familieleden het belangrijk vinden om het gevoel te hebben niet in de weg te lopen) zijn ook behoefte-items opgenomen in de vragenlijst die uit 1 of 2 deelvragen bestaan. 


\begin{tabular}{|c|c|c|}
\hline 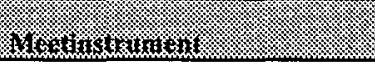 & (1) & $\sin$ \\
\hline $\begin{array}{l}\text { Algemene lijst } \\
\text { Sociaal-demografische variabelen }(10)\end{array}$ & + & \\
\hline Ziektegebonden variabelen (6) & + & \\
\hline Intensive care gelieerde variabelen (6) & + & \\
\hline $\begin{array}{l}\text { Behoeftelijst } \\
\text { Behoefte aan informatie (6) }\end{array}$ & + & \\
\hline Behoefte aan communicatie (6) & + & \\
\hline Behoefte aan ondersteuning (6) & + & \\
\hline Behoefte aan toegankelijkheid (6) & + & \\
\hline $\begin{array}{l}\text { Copinglijst } \\
\text { Copingstijl actief aanpakken (5) }\end{array}$ & & + \\
\hline Copingstijl sociale steun zoeken (5) & & + \\
\hline Copingstijl pall iatief reageren (2) & & + \\
\hline Copingstijl vermijden en afwachten (3) & & + \\
\hline
\end{tabular}

\subsubsection{Behoeften van familieleden}

Bij het totaal aantal items (24) is eerst naar de verdelingen gekeken.

Op grond van onvoldoende variantie bij drie behoefte-items (Polit \& Hungler, 1991) zijn deze verwijderd, te weten: (1) vindt $\mathbf{u}$ het belangrijk dat uw vragen eerlijk beantwoord worden, (2) vindt $u$ het belangrijk dat $u$ thuis opgebeld wordt als de situatie verslechtert en (3) vindt $\mathbf{u}$ het belangrijk dat $u$ verteld wordt wat de eventuele gevolgen van de opname voor uw familielid zijn. Een geroteerde factoranalyse leverde een duidelijke drie factorstructuur op. In tabel 4.6.1 worden de items en hun factorladingen weergegeven. Met uitzondering van drie items konden alle items worden toegewezen aan drie van de vier factoren. Omdat deze items relatief laag laden en niet eenduidig zijn op/naar de factor waarin ze logischerwijze ondergebracht dienen te worden de Cronbach's alpha's van de categorieën negatief beïnvloeden, is besloten deze items te verwijderen uit de vragenlijst "vindt $\mathbf{u}$ het belangrijk om tenminste eenmaal per dag informatie over uw familielid te ontvangen", "vindt $u$ het belangrijk om in de gelegenheid gesteld te worden voortdurend bij uw familielid aanwezig te zijn" en "vindt $u$ het belangrijk dat $u$ een overnachtingsmogelijkheid wordt aangeboden" (tabel 4.6.1). 
Tabel 4.6.1 Geroteerde factoranalyse (drie factoren) totale onderzoeksgroep $(\mathrm{N}=206$, vetgedrukte items zijn verwijderd).

\begin{tabular}{|c|c|c|c|c|c|c|}
\hline \multirow[t]{2}{*}{ 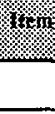 } & & ring & y. & \multicolumn{3}{|c|}{ 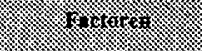 } \\
\hline & & & & 1 & 2 & 3 \\
\hline 82 & $\begin{array}{l}\text { Vindt } u \text { het belangrijk om direct na de opname uw familielid te } \\
\text { mogen bezoeken? }\end{array}$ & 3.51 .80 & .46 & .64 & .17 & .15 \\
\hline 87 & $\begin{array}{l}\text { Vindt } u \text { het belangrijk dat u koffie en thee kunt gebruiken wanneer } \\
u \text { daar behoefte aan heeft? }\end{array}$ & $3.3 / .77$ & .35 & .56 & -.09 & .13 \\
\hline 85 & Vindt $u$ het belangrijk dat bezoekuren op tijd beginnen? & $3.2 / .78$ & .33 & .56 & .14 & .01 \\
\hline 79 & Vindt $u$ het belangrijk dat $u$ het gevoel heeft niet in de weg te lopen? & $3.3 / .67$ & .26 & .51 & .00 & .00 \\
\hline 52 & $\begin{array}{l}\text { Vindt u het belangrijk om tenminste eenmaal per dag } \\
\text { informatie te krijgen over uw familielid? }\end{array}$ & & .34 & .49 & .29 & .09 \\
\hline 58 & $\begin{array}{l}\text { Vindt } u \text { het belangrijk dat } u \text { op iedere moment kunt informeren naar } \\
\text { de toestand van uw familielid? }\end{array}$ & $3.7 / .48$ & .32 & .49 & .16 & .23 \\
\hline 27 & $\begin{array}{l}\text { Vindt } u \text { het belangrijk dat, wanneer } u \text { het ziekenhuis verlaat, dit } \\
\text { verantwoord is gezien de algehele conditie van de patient? }\end{array}$ & 3.61 .53 & .23 & .47 & .09 & -.01 \\
\hline 50 & $\begin{array}{l}\text { Vindt } u \text { het belangrijk om iedere dag met dezelfde verpleegkundige } \\
\text { te kunnen spreken? }\end{array}$ & $2.5 / .87$ & .46 & -.16 & .65 & -.08 \\
\hline 46 & $\begin{array}{l}\text { Vindt u het belangrijk dat er een contactpersoon is tussen u en de } \\
\text { intensive care? }\end{array}$ & 3.01 .82 & .35 & .20 & .56 & -.00 \\
\hline 37 & $\begin{array}{l}\text { Vindt } u \text { het belangrijk te weten welke medische behandeling uw } \\
\text { familielid krijgt? }\end{array}$ & $3.3 / 73$ & .34 & .17 & .54 & .13 \\
\hline 84 & $\begin{array}{l}\text { Vindt } u \text { het belangrijk dat } u \text { de mogelijkheid krijgt uw familielid te } \\
\text { bezoeken wanneer } u \text { dat wenst? }\end{array}$ & $3.0 / .94$ & .35 & .18 & .53 & .20 \\
\hline 83 & $\begin{array}{l}\text { Vindt } u \text { het belangrijk dat } u \text { in de gelegenheid gesteld wordt om } \\
\text { voortdurend bij uw familielid aanwezig te kunnen zijn? }\end{array}$ & & .38 & .32 & .52 & -.09 \\
\hline 33 & $\begin{array}{l}\text { Vindt } u \text { het belangrijk dat iemand } u \text { vertelt hoe de apparatuur die } \\
\text { bij uw familielid gebruikt wordt werkt? }\end{array}$ & 2.61 .87 & .33 & .18 & .47 & .27 \\
\hline 56 & $\begin{array}{l}\text { Vindt } \mathrm{u} \text { het belangrijk dat er een vast tijdstip geboden wordt voor } \\
\text { het stellen van vragen? }\end{array}$ & 2.51 .96 & .18 & -.16 & .39 & .00 \\
\hline 29 & $\begin{array}{l}\text { Vindt } u \text { het belangrijk dat } u \text { op de hoogte gesteld wordt van een } \\
\text { eventuele overplaatsing van uw familielid? }\end{array}$ & $3.4 / .65$ & .16 & .14 & .35 & .12 \\
\hline 86 & $\begin{array}{l}\text { Vindt u het belangrijk dat er een overnachtingsmogelijkheid } \\
\text { geboden wordt? }\end{array}$ & & .19 & .28 & .33 & -.02 \\
\hline 75 & $\begin{array}{l}\text { Vindt } u \text { het belangrijk om met iemand op de intensive care over uw } \\
\text { gevoelens en ervaringen te kunnen spreken? }\end{array}$ & $2.1 / .89$ & .58 & -.00 & .01 & .76 \\
\hline 69 & $\begin{array}{l}\text { Vindt } u \text { het belangrijk dat een intensive care medewerker } u \\
\text { ondersteunt op de intensive care? }\end{array}$ & $2.7 / .95$ & .54 & .26 & .08 & .68 \\
\hline 73 & $\begin{array}{l}\text { Vindt } u \text { het belangrijk om met familieleden van andere intensive } \\
\text { care patiênten in contact te kunnen treden? }\end{array}$ & $2.0 / .97$ & .38 & .17 & -.08 & .59 \\
\hline 67 & $\begin{array}{l}\text { Vindt } u \text { het belangrijk dat u ondersteuning krijgt van een pastoraal } \\
\text { medewerker op de intensive care? }\end{array}$ & $1.7 / .86$ & .45 &. .25 & .23 & .58 \\
\hline 63 & $\begin{array}{l}\text { Vindt } u \text { het belangrijk dat er iemand bij } u \text { is als } u \text { voor de eerste keer } \\
\text { uw familielid bezoekt? }\end{array}$ & $3.3 / .87$ & .28 & .33 & .19 & .37 \\
\hline
\end{tabular}


De uiteindelijke schaal bestaat, na verwijdering van de drie behoefte-items, uit 18 behoefteitems verdeeld over drie factoren. In het onderzoek zijn daarom de eerder beschreven vier behoeftecategorieën ("informatie", "communicatie", "ondersteuning" en "toegankelijkheid") conform de factorstructuur gewijzigd in drie behoeftecategorieën ("informatie", "ondersteuning" en "toegankelijkheid"). De factoranalyse steunt de eerder veronderstelde driedeling met betrekking tot behoeften van familieleden. Tabel 4.6.1.1 toont de Cronbach's alpha's van de totale lijst (.72) en de afzonderlijke drie behoeftecategorieën.

Tabel 4.6.1.1 Overzicht Cronbach's alpha's behoeftecategorieën

\begin{tabular}{|c|c|}
\hline 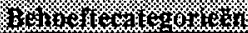 & 桡 \\
\hline Informatie & .59 \\
\hline Ondersteuning & .62 \\
\hline Toegankelijkheid & .60 \\
\hline Begeleiding (totale lijst) & .72 \\
\hline
\end{tabular}

Uit tabel 4.6.1.1 is af te leiden dat de grootste interne consistentie is gevonden in de totale behoeftelijst. In de voorgaande hoofdstukken is beschreven dat, naast de drie afzonderlijke behoeftecategorieën ook gekeken wordt naar behoeften van familieleden in het algemeen (begeleiding), waarbij begeleiding gezien dient te worden als het totaal van behoeften aan informatie, ondersteuning en toegankelijkheid. De behoeftecategorie "behoeften aan begeleiding" bestaat in deze studie uit 18 behoefte-items (de totale lijst). Deze categorie is gevormd nadat de afzonderlijke categorieën, die hierna achtereenvolgens besproken worden, op grond van factoranalyse zijn samengesteld. De totale lijst is af te leiden uit tabel 4.6.1.2. 
Tabel 4.6.1.2 Algemene behoeftecategorie "behoeften aan begeleiding".

\begin{tabular}{|c|c|c|}
\hline 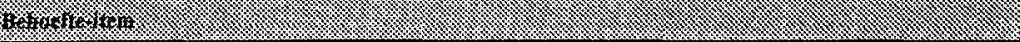 & 48: & 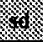 \\
\hline Vindt $u$ het belangrijk dat $u$ op ieder moment kan informeren naar de toestand van uw familielid? & 3.7 & .48 \\
\hline $\begin{array}{l}\text { Vindt } u \text { het belangrijk dat, wanneer } u \text { het ziekenhuis verlaat, dit verantwoord is gezien de algehele conditie van } \\
\text { uw familielid? }\end{array}$ & 3.6 & .54 \\
\hline Vindt $\mathbf{u}$ het belangrijk om direct, na opname, uw familielid te mogen bezoeken? & 3.5 & .80 \\
\hline Vindt $u$ het belangrijk tijdig op de hoogte gesteld te worden van een eventuele overplaatsing van uw familielid? & 3.4 & .65 \\
\hline Vindt $u$ het belangrijk te weten welke medische behandeling uw familielid krijgt? & 3.3 & .73 \\
\hline Vindt $u$ het belangrijk dat er iemand bij $u$ is als $u$ voor het eerst uw familielid bezoekt? & 3.3 & .87 \\
\hline Vindt $u$ het belangrijk dat $u$ het gevoel heeft niet in de weg te lopen? & 3.3 & .67 \\
\hline Vindt $u$ het belangrijk dat u koffie en thee kunt gebruiken wanneer $u$ daar behoefte aan heeft? & 3.3 & .77 \\
\hline Vindt u het belangrijk dat bezoekuren op tijd beginnen? & 3.2 & .78 \\
\hline Vindt u het belangrijk dat $u$ de mogelijkheid krijgt uw familielid te bezoeken wanneer $u$ dat wilt? & 3.0 & .94 \\
\hline Vindt $u$ het belangrijk dat er een contactpersoon is tussen $u$ en de intensive care? & 3.0 & .82 \\
\hline Vindt $\mathbf{u}$ het belangrijk dat iemand van de intensive care $u$ ondersteunt buiten $u w$ familie en/of vrienden? & 2.7 & .95 \\
\hline Vindt $u$ het belangrijk dat iemand $u$ vertelt hoe de apparatuur die bij uw familielid gebruikt wordt werkt? & 2.6 & .87 \\
\hline Vindt $u$ het belangrijk om iedere dag met dezelfde verpleegkundige te kunnen spreken? & 2.5 & .87 \\
\hline Vindt $u$ het belangrijk dat er een vast tijdstip geboden wordt om vragen te stellen? & 2.5 & .94 \\
\hline $\begin{array}{l}\text { Vindt u het belangrijk om met iemand van de intensive care over uw gevoelens en ervaringen te kunnen } \\
\text { spreken? }\end{array}$ & 2.1 & .89 \\
\hline $\begin{array}{l}\text { Vindt } u \text { het belangrijk om met mensen die ook een familielid op de intensive care bezoeken in contact te } \\
\text { treden? }\end{array}$ & 2.0 & .97 \\
\hline Vindt $u$ het belangrijk dat $u$ ondersteuning krijgt van een pastoraal medewerker uit het ziekenhuis? & 1.7 & 86 \\
\hline
\end{tabular}

Min. score $=1$

Max. score $=4$

\subsubsection{Behoeften aan informatie}

De behoeftecategorie "behoeften aan informatie" bestaat in deze studie uit 7 behoefte-items die, op grond van statistische samenhang zijn samengevoegd. De interne consistentie van deze categorie is .59 . Van de 6 behoefte-items uit de vragenlijst die de behoeftecategorie "behoeften aan informatie" vertegenwoordigen (zie bijlage 8), zijn twee items verwijderd (1) (vindt $u$ het belangrijk dat $u$ verteld wordt wat de eventuele gevolgen van de opname voor uw familielid zijn en (2) vindt $u$ het belangrijk dat $u$ thuis opgebeld wordt als de situatie van uw familielid verslechtert) ten gevolge van onvoldoende variantie $(\%>80 \%)$. Drie behoefte-items uit de categorie "behoeften aan communicatie" zijn, op grond van hoge factorladingen in de categorie "behoeften aan informatie" aan deze categorie toegevoegd (behoefte aan een contactpersoon, behoefte om iedere dag met dezelfde verpleegkundige te spreken en de behoefte aan een vast tijdstip voor het stellen van vragen). 
Een behoefte-item uit de categorie "behoeften aan toegankelijkheid" (behoefte om op ieder gewenst moment op bezoek te kunnen) is om dezelfde reden aan de categorie "behoeften aan informatie" toegevoegd en én behoefte-item (behoefte om verantwoord het ziekenhuis te verlaten) is verwijderd uit de categorie "behoeften aan informatie" en toegevoegd aan de categorie "toegankelijkheid". De behoeftecategorie "behoeften aan informatie" bestaat uiteindelijk uit 7 behoefte-items (tabel 4.6.1.1).

Tabel 4.6.1.1 Behoeftecategorie "behoeften aan informatie op de intensive care"

\begin{tabular}{|c|c|c|}
\hline 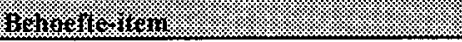 & Mtair & 位 \\
\hline Op de hoogte gesteld worden van overplaatsing & 3.4 & .65 \\
\hline Informatie krijgen over de medische behandeling & 3.3 & .73 \\
\hline Op ieder gewenst moment op bezoek kunnen & 3.0 & .94 \\
\hline Een contactpersoon hebben & 3.0 & .82 \\
\hline Uitleg krijgen over de apparatuur & 2.6 & .87 \\
\hline Een vast tijdstip hebben voor vragen & 2.5 & .94 \\
\hline Dezelfde verpleegkundige kunnen spreken & 2.5 & .87 \\
\hline
\end{tabular}

\subsubsection{Behoeften aan ondersteuning}

De behoeftecategorie "behoeften aan ondersteuning" bestaat in dit onderzoek uit 5 behoefteitems (tabel 4.6.1.2) die, op grond van statistische samenhang, zijn samengevoegd.

De interne consistentie van deze categorie is .62. Eén behoefte-item (vindt $u$ het belangrijk het gevoel te hebben niet in de weg te lopen) is, ten gevolge van een lage factorlading uit deze categorie (zie tabel 4.6.1) "behoeften aan ondersteuning" verwijderd en toegevoegd aan de categorie "behoeften aan toegankelijkheid".

Tabel 4.6.1.2 Behoeftecategorie "behoeften aan ondersteuning" op de intensive care.

\begin{tabular}{|c|c|c|}
\hline 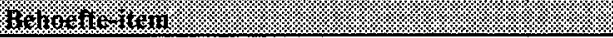 & / & 樂 \\
\hline De aanwezigheid van een medewerker bij het eerste bezoek & 3.3 & .87 \\
\hline Ondersteuning op de intensive care krijgen & 2.7 & .95 \\
\hline Over ervaringen op de intensive care kunnen spreken & 2.1 & .89 \\
\hline Contact hebben met andere familieleden op de intensive care & 2.0 & .97 \\
\hline Ondersteuning van een pastoraal medewerker op de intensive care & 1.7 & .86 \\
\hline
\end{tabular}




\subsubsection{Behoeften aan toegankelijkheid}

De behoeftecategorie "behoeften aan toegankelijkheid" bestaat, in deze studie, uit 6 behoefteitems (tabel 4.6.1.3) die op grond van statistische samenhang gecategoriseerd zijn.

De interne consistentie van deze categorie is .60 . Drie van de 6 behoefte-items (vindt $\mathbf{u}$ het belangrijk dat er overnachtingsmogelijkheden zijn; vindt $u$ het belangrijk om op ieder gewenst moment op bezoek te kunnen en vindt $u$ het belangrijk om voortdurend bij uw familielid aanwezig te kunnen zijn) uit de categorie "behoeften aan toegankelijkheid" (zie tabel 4.6.1) zijn verwijderd op grond van lage factorladingen. Uit de categorie "behoeften aan communicatie" is 1 behoefte-item toegevoegd (vindt u het belangrijk om op ieder gewenst moment naar uw familielid te kunnen informeren) aan de categorie "behoeften aan toegankelijkheid". Uit de categorie "behoeften aan informatie" is 1 behoefte-item (vindt $u$ het belangrijk om het ziekenhuis verantwoord te kunnen verlaten) toegevoegd aan de categorie "behoeften aan toegankelijkheid" en er is 1 behoefte-item uit de categorie "behoeften aan ondersteuning" (vindt u het belangrijk om het gevoel te hebben niet in de weg te lopen) aan de categorie "behoeften aan toegankelijkheid" toegevoegd.

Tabel 4.6.1.3 Behoeftecategorie "behoeften aan toegankelijkheid" op de intensive care.

\begin{tabular}{|c|c|c|}
\hline 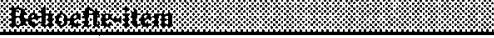 & maxis & 椢 \\
\hline Op ieder gewenst moment informatie kunnen krijgen & 3.7 & .48 \\
\hline Verantwoord het ziekenhuis kunnen verlaten & 3.6 & .54 \\
\hline Direct na opname van de patient op bezoek kunnen & 3.5 & .80 \\
\hline Het gevoel hebben niet in de weg te lopen & 3.3 & .67 \\
\hline Gebruik kunnen maken van koffie en thee & 3.3 & .77 \\
\hline Bezoekuren die op tijd beginnen & 3.2 & .78 \\
\hline
\end{tabular}

\subsubsection{Behoeften aan begeleiding}

De totale vragenlijst bestaat uiteindelijk uit totaal 18 behoefte-items waarvan 7 items de categorie "behoeften aan informatie", 5 items in de categorie "behoeften aan ondersteuning" en 6 items in de categorie "behoeften aan toegankelijkheid" vormen. Het totaal van de drie behoeftecategorieën wordt gevormd door de algemene behoeftecategorie "behoeften aan begeleiding". De meerwaarde van deze categorie is gelegen in het gegeven dat verpleegkundigen en verpleegkundige opleidingen over het algemeen spreken over begeleiding van familieleden zonder dat dit begrip geoperationaliseerd is. In deze studie is de behoeftecategorie "begeleiding" geoperationaliseerd in drie subcategorieën die tezamen 18 behoefteitems tellen. De behoeftecategorie "behoeften aan communicatie" is komen te vervallen. Hieraan ligt met name de duidelijke drie-factor-structuur van de totale lijst ten grondslag, anderzijds is het zo dat de behoefte-items in de categorie "behoeften aan communicatie" gemakkelijk zijn onder te brengen in de categorieën "behoeften aan informatie" en toegankelijkheid". Tabel 4.6.1.4 toont de interne consistentie van de vier behoeftecategorieën. 
Tabel 4.6.1.4 Correlatiematrix vier behoeftecategorieën

\begin{tabular}{|c|c|c|c|c|c|}
\hline & 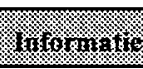 & 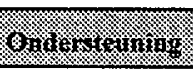 & 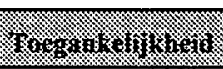 & 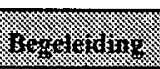 & Mr.nstrig \\
\hline (6) & - & $.28 * *$ & $.29^{* *}$ & $.70^{* *}$ & 2.9 \\
\hline 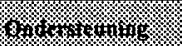 & & - & $.31 * *$ & $.79 * *$ & 2.4 \\
\hline (2) & & & . & $.77^{* *}$ & 3.5 \\
\hline 48. & & & & - & 2.9 \\
\hline
\end{tabular}

2-tailed sign: $* *<.001$

\subsubsection{Coping}

Om de copingstijl van familieleden op de intensive care te meten, is de verkorte Utrechtse Coping Lijst gebruikt (Janssen et al., in voorbereiding). Deze lijst is afgeleid van de Utrechtse Coping Lijst (Schreurs, 1987) die uit 47 items bestaat en de feitelijke wijze van probleemhantering meet. De in deze studie gebruikte schaal (Janssen et al., in voorbereiding), bestaat uit 15 items die samen vier copingstijlen meten. Op een 4-punt-Likertschaal, oplopend van zelden of nooit tot zeer vaak, kunnen respondenten aangeven hoe zij in het algemeen op de beschreven wijze reageren bij problemen. De te onderscheiden copingstijlen zijn:

\section{Actief het probleem aanpakken \\ 2. Sociale steun zoeken \\ 3. Afwachten en vermijden \\ 4. Palliatief gedrag}

\section{Definiëring van begrippen}

De copingstijl "actief aanpakken" ofwel "actief probleem oplossen" is gedefinieerd als probleemgericht handelend en probleemgericht evaluerend copinggedrag met als doel de stressor te beheersen. Hierbij wordt de situatie rustig van alle kanten bekeken, worden de zaken op een rijtje gezet en wordt er doelgericht en met vertrouwen te werk gegaan om het probleem op te lossen (Schreurs et al., 1993).

Bij de copingstijl "sociale steun zoeken" gaat het om informatie die iemand de overtuiging geeft dát men om hem geeft, dat men hem waardeert en dat hij deel uitmaakt van een netwerk van mensen die onderling contact onderhouden en elkaar helpen (Schreurs, 1987).

"Sociale steun zoeken" wil zeggen dat troost en begrip gezocht wordt bij anderen en dat zorgen aan iemand verteld worden, waarbij om hulp wordt gevraagd (Schreurs et al., 1993). 
"Afwachten en vermijden" is het vermijden van confrontatie met de stressor en het niet evalueren van probleemoplossende gedragsmogelijkheden (Furda, 1995). Het kan omschreven worden als "de zaak op zijn beloop laten", "de situatie uit de weg gaan" of "afwachten wat er gaat gebeuren" (Schreurs et al., 1993).

"Palliatief gedrag" is afleiding zoeken en zich met andere dingen bezighouden om niet aan het probleem te hoeven denken, proberen zich wat prettiger te voelen door te roken, te drinken of zich wat te ontspannen (Schreurs et al., 1993).

$\mathrm{Bij}$ geroteerde factoranalyse (tabel 4.6.2) komt de factorstructuur overeen met de bestaande copingstijlen (U.C.L., Janssen et al., in voorbereiding). De Alpha's voor de afzonderlijke stijlen zijn voor respectievelijk "actief aanpakken", "sociale steun zoeken", "afwachten en vermijden" en "palliatief gedrag" $.75, .76, .57$ en .30 . De copingstijl "palliatief gedrag" wordt, ondanks de lage Alpha (.30), in deze studie ten behoeve van het theoretische belang meegenomen.

De Cronbach's alpha voor de totale lijst is .70. Tabel 4.6.2 laat de Cronbach's alpha's van de copingstijlen zien, uitgevoerd voor de groep van 206 familieleden. Tabel 4.6.2.1 toont de interne consistentie van de vier copingstijlen.

Tabel 4.6.2 Geroteerde factormatrix op vier factoren $(n=206)$

\begin{tabular}{|c|c|c|c|c|c|}
\hline (6) & xysor & $8 \%$ & 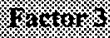 & 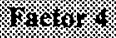 & . \\
\hline $\begin{array}{l}\text { Actief aanpakken } \\
\text { direct ingrijpen als er moeilijkheden zijn } \\
\text { een probleem van alle kanten bekijken } \\
\text { verschillende mogelijkheden bedenken om een } \\
\text { probleem op te lossen } \\
\text { doelgericht te werk gaan } \\
\text { de zaken eerst op een rij zetten } \\
\text { Sociale steun zoeken } \\
\text { je zorgen met iemand delen } \\
\text { iemand om hulp vragen } \\
\text { je gevoelens tonen } \\
\text { troost en begrip zoeken } \\
\text { laten merken dat je ergens mee zit } \\
\text { Afwachten en vermijden } \\
\text { je neerleggen bij de gang van zaken } \\
\text { moeilijke situaties zoveel mogelijk uit de weg gaan } \\
\text { toegeven om moeilijke situaties te vermijden } \\
\text { Palliatief gedrag } \\
\text { afleiding zoeken } \\
\text { aan andere dingen denken die niet met het probleem } \\
\text { te maken hebben }\end{array}$ & $\begin{array}{l}.62 \\
.75 \\
.68 \\
.75 \\
.67 \\
\\
.10 \\
.11 \\
.10 \\
.02 \\
.11 \\
-.13 \\
-.24 \\
-.03 \\
\\
.08 \\
.05\end{array}$ & $\begin{array}{l}.05 \\
.13 \\
.06 \\
.04 \\
.13 \\
\\
.63 \\
.50 \\
.76 \\
.82 \\
.73 \\
.01 \\
.02 \\
.05 \\
\\
.21 \\
.05\end{array}$ & $\begin{array}{r}-.14 \\
-.05 \\
-.08 \\
\\
-.13 \\
.11 \\
\\
.21 \\
-.21 \\
-.01 \\
.09 \\
-.14 \\
.72 \\
.47 \\
.79 \\
.00 \\
.20\end{array}$ & $\begin{array}{l}.14 \\
.04 \\
.18 \\
\\
-.04 \\
-.27 \\
\\
.05 \\
.42 \\
.06 \\
.10 \\
.07 \\
.00 \\
.45 \\
.12 \\
.78 \\
.60\end{array}$ & .75 \\
\hline
\end{tabular}

* correlatie volgens Pearson 
Tabel 4.6.2.1 Correlatiematrix vier copingstijlen

\begin{tabular}{|c|c|c|c|c|c|}
\hline & 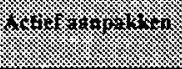 & 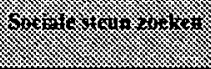 & (1) & in & in \\
\hline Actief aanpakken & - & $.25 * *$ & $-.24 * *$ & .09 & 3.0 \\
\hline Sociale steun zoeken & & - & .04 & $.33 * *$ & 2.3 \\
\hline Afwachten en vermijden & & & - & $.23^{* *}$ & 1.9 \\
\hline Palliatief gedrag & & & & - & 2.2 \\
\hline
\end{tabular}

2-tailed signif: **<.001

\subsubsection{Sociaal-demografische factoren}

De sociaal-demografische kenmerken van familieleden uit deze studie zijn gemeten door 7 algemene factoren (tabel 4.6.3).

\section{Tabel 4.6.3 Sociaal-demografische factoren}

\begin{tabular}{l} 
\% \\
Geslacht \\
Relatie met de patient \\
Leeftijd \\
Religie \\
Woongebied \\
Sociaal-economische status \\
Bekendheid met de intensive care \\
\hline
\end{tabular}

Naast het geslacht van de respondenten, dat voor zich spreekt, wordt, met betrekking tot de relatie die het familielid heeft met de patiënt, het onderscheid gemaakt tussen (levens) partners en overige familieleden. De leeftijd van de respondenten wordt geclassificeerd in drie categorieën (20 - 40 jaar, 41 - 60 jaar en ouder dan 60 jaar). Voor wat betreft het woongebied van familieleden is gekeken naar de provincie Utrecht, de provincies Gelderland en Overijssel en de rest van Nederland.

De sociaal-economische status van het familielid is een combinatie van de hoogst gevolgde opleiding en het beroep. Deze variabele is geclassificeerd in drie classen, namelijk: laag, midden en hoog. Tot slot is in deze studie gekeken of het familielid bekend is met de intensive care. 


\subsubsection{Intensive care gelieerde factoren}

In deze studie worden 4 intensive care gelieerde factoren gemeten (tabel 4.6.4).

Tabel 4.6.4 Overzicht intensive care gelieerde factoren

徒1
Wachttijd op opname
Uitstel van de opname
Tijdstip van afname van de vragenlijst
Het meemaken van een onplezierige ervaring

Zoals in hoofdstuk 3 al werd vermeld, is in geen van de eerdere studies, de invloed van intensive care gelieerde factoren op behoeften van familieleden onderzocht. In deze studie is gekeken of de patiënt geconfronteerd is geweest met een wachttijd op opname.

Ook is gekeken of de opname uitgesteld is geweest, nadat deze gepland is.

Hiernaast is het afnametijdstip van de vragenlijst meegenomen in het onderzoek en wordt het onderscheid gemaakt tussen de eerste 24 uur na opname van de patiënt, tussen de 24 en 48 uur na opname van de patiënt en tussen de 48 en 72 uur na opname van de patiënt op de intensive care.

De variabele "onplezierige ervaring" wordt gekenmerkt door (1) ervaringen die patiëntgebonden van aard zijn (het zien van apparatuur bij het bed van de patiënt en de aanblik van de patiënt), (2) medewerkergebonden ervaringen (opvang en benadering van de familie op de intensive care, informatie en communicatie) en (3) organisatiegebonden ervaringen (wachttijden op de intensive care en de organisatie op de intensive care).

\subsubsection{Ziektegebonden factoren}

Er is in deze studie gekeken naar de invloed van 6 ziektegebonden factoren op behoeften van familieleden (tabel 4.6.5). Met uitzondering van de opname-indicatie (Leske, 1991 \& 1992) is de invloed van ziektegebonden factoren op behoeften van familieleden niet eerder onderzocht.

Tabel 4.6.5 Overzicht ziektegebonden factoren

\begin{tabular}{l} 
\% \\
\hline Opname-indicatie \\
Planning van de opname \\
Mechanische beademing \\
Opnamefrequentie \\
Inschatting van de mate van levensbedreiging van de patient (door het familielid) \\
Inschatting van de mate van levensbedreiging van de patiënt (door de verpleegkundige) \\
\hline
\end{tabular}


Bij de opname-indicatie van de patiënt wordt in deze studie het onderscheid gemaakt tussen hartoperatiepatiënten en overige intensive care patiënten, waarbij neurochirurgische patiënten buiten beschouwing zijn gelaten. Bij planning van de opname is gekeken of het een spoedopname of een geplande opname betreft. Hiernaast is gekeken of de patiënt mechanisch beademd wordt of spontaan ademt. Bij opnamefrequentie is gekeken of de patiënt eerder opgenomen is geweest op de intensive care. Tot slot is met betrekking tot de inschatting van de levensbedreiging van de patiënt het onderscheid gemaakt tussen zeer levensbedreigend, levensbedreigend en niet levensbedreigend. Dit onderscheid is op basis van rapportcijfers tussen de 1 en de 10 tot stand gekomen waarbij de cijfers $1 \mathrm{t} / \mathrm{m} 4$ een niet levensbedreigende situatie vertegenwoordigen, de cijfers $5 \mathrm{t} / \mathrm{m} 7$ een levensbedreigende situatie vertegenwoordigen en de cijfers $8 \mathrm{t} / \mathrm{m} 10$ een zeer levensbedreigende situatie vertegenwoordigen.

De inschatting is zowel door de familie als door de verpleegkundige gedaan.

\subsubsection{De analyses}

In deze paragraaf zullen in het kort de statistische analyses besproken worden die gebruikt zijn ten behoeve van de dataverwerking voor de beantwoording van de verschillende onderzoeksvraagstellingen (hoofdstuk 3).

Om de behoeften van familieleden van intensive care patiënten te analyseren is een onderscheid gemaakt tussen familieleden van hartoperatiepatiënten en overige intensive care patiënten. Hiervoor zijn $\chi^{2}$ en t-toetsen toegepast. Om de invloed van sociaal-demografische factoren, intensive care gelieerde factoren en ziektegebonden factoren op behoeften te analyseren zijn zowel $\chi^{2}$ als t-toetsen toegepast. Om de invloed van copingfactoren op behoeften van familieleden te analyseren zijn eveneens $\chi^{2}$ en t-toetsen toegepast.

Bij de typologie van familieleden is in eerste instantie de invloed van typen familieleden op behoeften geanalyseerd waarbij wederom het onderscheid tussen familieleden van hartoperatiepatiënten en overige intensive care patiënten is gemaakt. Om de invloed van bepaalde typen familieleden op behoeften te analyseren zijn $\chi^{2}$ toetsen uitgevoerd. De invloed van sociaal-demografische factoren, intensive care gelieerde factoren, ziektegebonden factoren en copingfactoren is geanalyseerd met behulp van $\chi^{2}$ toetsen.

Voor het nagaan van de onderlinge samenhang tussen de onafhankelijke en overige factoren zijn Pearson Correlaties berekend. De multivariate analyses zijn uitgevoerd met factoranalyses en met logistische regressie analyses. 


\subsection{Samenvatting}

In dit hoofdstuk is een overzicht gepresenteerd van de setting waarbinnen het onderzoek heeft plaatsgevonden, de onderzoekspopulatie, de respons en de methode van onderzoek. Er is kort ingegaan op de pilotstudie die vooraf gegaan is aan het onderzoek. Het, uit drie vragenlijsten bestaande, meetinstrument is besproken aan de hand van het onderzoeksmodel.

Behoeften van familieleden worden gemeten met een uit drie categorieën bestaande vragenlijst, gebaseerd op de C.C.F.N.I. (Molter, 1979). Deze lijst bestaat na vertaling, het uitvoeren van de pilotstudie verschillende Delphi-ronden en factoranalyse, uit 18 behoefte-items (zie figuur 4.7). De drie afzonderlijke behoeftecategorieën vormen de algemene behoeftecategorie "behoeften aan begeleiding". Copinggedrag van familieleden wordt gemeten met behulp van de 15-item Utrechtse Coping Lijst (Janssen et al., in voorbereiding). Onafhankelijke factoren (sociaal-demografische-, intensive care gelieerde- en ziektegebonden factoren) worden gemeten met een algemene vragenlijst bestaande uit 19 items. Het meetinstrument bestaat uit totaal 52 vragen.

Figuur 4.7 Totstandkoming vragenlijst

46-itemlijst van Daley, gebaseerd op de C.C.F.N.I (Molter, 1979)

Nederlandse vertaling

$\rightarrow \quad 32$ items overgenomen 1 item gesplitst in 2 items 33 behoefte-items

Delphi-ronden

1e en $2 e$ orde factoranalyse Pilotstudy

$\rightarrow \quad 17$ items (Noordhuis \& Roofthooft, 1991)

\section{Hoofdonderzoek}

Delphi-ronden

$\rightarrow \quad 6$ items samengevoegd tot 2 items

11 items toegevoegd

24 items

Factoranalyse

$\rightarrow \quad$ 18-itemlijst 


\section{RESULTATEN I}

Een eerste beschrijving van de resultaten gericht op het verschil in behoeften van familieleden van hartoperatiepatiënten en familieleden van overige intensive care patiënten

\subsection{Inleiding}

In dit hoofdstuk worden de eerste resultaten van de behoeften van familieleden beschreven, waarbij de afhankelijke variabelen "behoeften aan informatie, ondersteuning, toegankelijkheid en begeleiding" stuk voor stuk worden bekeken. De resultaten, verzameld in één interview per respondent, zijn van toepassing op twee onderzoeksgroepen, te weten familieleden van patiënten die een open-hartoperatie hebben ondergaan en op de intensive care zijn opgenomen en familieleden van overige intensive care patiënten. In dit hoofdstuk wordt met name gekeken naar de eventuele verschillen tussen de groep familieleden van hartoperatiepatiënten en de groep familieleden van overige intensive care patiënten op de intensive care.

Vervolgens worden de onafhankelijke en overige factoren (sociaal-demografische variabelen, intensive care gelieerde variabelen, ziektegebonden variabelen en copingstijlen) achtereenvolgens en per onderzoeksgroep beschreven, waarbij eveneens steeds gekeken wordt naar verschillen. Alleen de significante resultaten worden beschreven.

\subsection{Overzicht behoeftecategorieën}

Behoeften van familieleden worden in dit onderzoek gemeten met de Nederlandse aangepaste versie van de Critical Care Family Needs Inventory van Molter (1979).

Van de 24 oorspronkelijke behoefte-items zijn drie items verwijderd ten gevolge van onvoldoende verklaarde variantie per item. Factoranalyse resulteerde in een duidelijke driefactorstructuur (4.6.1). Met uitzondering van drie items zijn alle items toegewezen aan drie factoren. Omdat eerder genoemde items laag laden op de factor waar ze logischerwijze ondergebracht dienen te worden, is besloten deze items uit de vragenlijst te verwijderen (4.6.1).

Behoeften van familieleden worden in deze studie, in tegenstelling tot andere studies (Molter, 1979; Daley, 1984; Forrester et al., 1990; McHale \& Bellinger, 1988; Kleinpell \& Powers, 1992; Leske, 1991 \& 1992; Foss \& Tenholder, (1993), gemeten in drie behoeftecategorieën (behoeften aan informatie, ondersteuning en toegankelijkheid) die samen de algemene behoeftecategorie begeleiding vormen (hoofdstuk 4). De behoeftecategorie informatie bestaat uit 7 behoefte-items $(\alpha=.59)$, de behoeftecategorie ondersteuning bestaat uit 5 behoefte-items $(\alpha=.62)$ en de behoeftecategorie toegankelijkheid bestaat uit 6 behoefte-items $(\alpha=60)$. De totale lijst bestaat uit 18 behoefte-items $(\alpha=.72)$ die tezamen de algemene behoeftecategorie begeleiding vormen. Tabel 5.2 toont de resultaten van de behoeftecategorieën, waarbij het onderscheid gemaakt wordt tussen familieleden van hartoperatiepatiënten en familieleden van overige intensive care patiënten. 


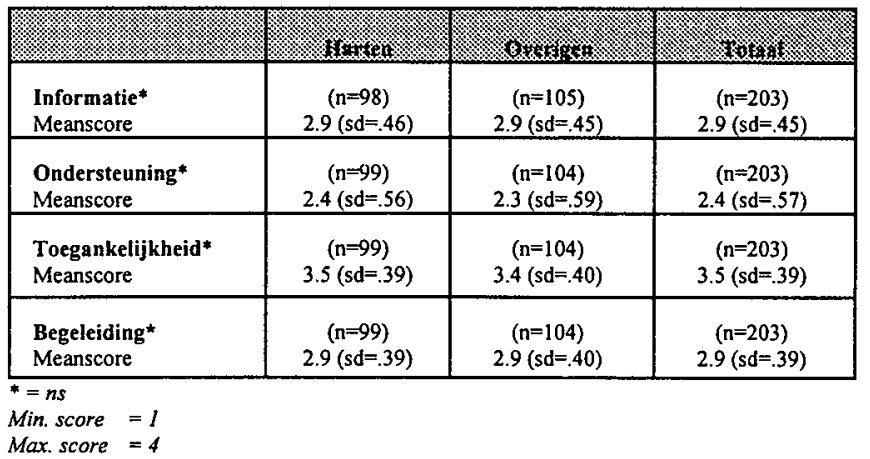

In tabel 5.2 is te zien dat behoeften van familieleden van hartoperatiepatiënten en behoeften van familieleden van overige intensive care patiënten in de vier categorieën niet of nauwelijks verschillen. Duidelijk is dat familieleden behoeften aan toegankelijkheid het meest belangrijk vinden. In de totale onderzoeksgroep is hier de meanscore 3.5 (sd .39), in de groep familieleden van hartoperatiepatiënten 3.5 (sd .39) en de groep familieleden van overige intensive care patiënten 3.4 (sd .40).

Behoeften aan informatie heeft in alle onderzoeksgroepen een meanscore van 2.9 (sd .46, $.45, .45$ ). Behoeften aan ondersteuning, de "minst" belangrijk gescoorde behoeftecategorie scoort in de totale onderzoeksgroep een gemiddelde van 2.4 (sd .57), in de groep familieleden van hartoperatiepatiënten een gemiddelde van 2.4 (sd .56) en de groep familieleden van overige intensive care patiënten een gemiddelde van 2.3 (sd .59). Behoeften aan begeleiding, het totaal van de drie categorieën "informatie, ondersteuning en toegankelijkheid", geeft een gemiddelde score van 2.9 in alle onderzoeksgroepen (sd .39, .40, .39).

Duidelijk wordt dat behoeften van familieleden op de intensive care aan informatie, ondersteuning en toegankelijkheid belangrijk zijn. Twee categorieën scoren ruim boven de algemeen gemiddelde score van 2.5 (toegankelijkheid en informatie). Alleen de behoeftecategorie "ondersteuning" heeft een gemiddelde score die lager is (2.4) dan de algemeen gemiddelde score. De opname-indicatie van de patiënt (hartoperatie of overige intensive care indicatie) is niet van invloed op de behoeften van diens familieleden.

\subsection{Overzicht sociaal-demografische variabelen}

Aan het onderzoek hebben $65(32 \%)$ mannelijke respondenten en $141(68 \%)$ vrouwelijke respondenten deelgenomen, waarbij een gelijke verdeling bestaat tussen de familieleden van hartoperatiepatiënten en familieleden van overige intensive care patiënten. De gemiddelde leeftijd van de totale onderzoeksgroep is 51 jaar (sd 14.9) en varieert tussen de 20 en 83 jaar. De gemiddelde leeftijd van de groep familieleden van hartoperatiepatiënten is 50.7 jaar (sd 15.8). De gemiddelde leeftijd van familieleden van overige intensive care patiënten is 51.4 jaar (sd 14.0). 
Tabel 5.3 Leeftijd en geslacht van familieleden van intensive care patiënten (\%).

\begin{tabular}{|c|c|c|}
\hline & 8 & (1) \\
\hline $\begin{array}{l}\text { Geslacht* } \\
\text { Vrouwen } \\
\text { Totaal }\end{array}$ & $\begin{array}{r}67 \\
100 \\
\end{array}$ & $\begin{array}{r}70 \\
100 \\
\end{array}$ \\
\hline $\begin{array}{c}\text { Leeftijd } \\
20-40 \mathrm{jr} \\
41-60 \mathrm{jr} \\
>60 \mathrm{jr} \\
\text { Totaal }\end{array}$ & $\begin{array}{r}30 \\
35 \\
35 \\
100\end{array}$ & $\begin{array}{r}25 \\
45 \\
30 \\
100\end{array}$ \\
\hline
\end{tabular}

$*=n s$

Zoals in tabel 5.3 is te zien komen er evenveel vrouwen voor in beide groepen familieleden. Ook de mannen zijn in beide groepen gelijk verdeeld evenals de leeftijd. De relatie waarin de familieleden staan ten opzichte van de patiënt is onderverdeeld in partners en andere familieleden (broer, zus, ouder, kind, kleinkind of andere naaste). Tabel 5.3.1 laat zien dat de grootste groep partners in de groep familieleden van hartoperatiepatiënten $\left(\chi^{2}=4.29, p=.03\right.$, $\mathrm{df}=1$ ) voorkomen $(67 \%)$. In de groep familieleden van overige intensive care patiënten is $53 \%$ partner van de patiënt.

Van het totaal aantal (206) respondenten zegt de grootste groep familieleden gelovig te zijn. $\mathrm{Bij}$ de familieleden van hartoperatiepatiënten geeft $73 \%$ aan gelovig te zijn, in de groep familieleden van overige intensive care patiënten is $66 \%$ gelovig. Een duidelijk verschil tussen beide groepen is niet gevonden.

Tabel 5.3.1 Relatie, geloof, woongebied en status van familieleden van intensive care patiënten (\%).

\begin{tabular}{|c|c|c|c|c|}
\hline & א. & א.1. & s. & אx. \\
\hline $\begin{array}{l}\text { Relatie } \\
\text { Partner } \\
\text { Totaal } \\
\end{array}$ & $\begin{array}{r}67 \\
100 \\
\end{array}$ & $\begin{array}{r}53 \\
100 \\
\end{array}$ & 1 & .03 \\
\hline $\begin{array}{l}\text { Geloof } \\
\text { Ja } \\
\text { Totaal } \\
\end{array}$ & $\begin{array}{r}73 \\
100 \\
\end{array}$ & $\begin{array}{r}66 \\
100 \\
\end{array}$ & & ns \\
\hline $\begin{array}{l}\text { Woongebied } \\
\text { Utrecht } \\
\text { Gelderland en Overijssel } \\
\text { Rest Nederland } \\
\text { Totaal } \\
\end{array}$ & $\begin{array}{r}22 \\
42 \\
36 \\
100 \\
\end{array}$ & $\begin{array}{r}45 \\
20 \\
35 \\
100 \\
\end{array}$ & 2 & .00 \\
\hline $\begin{array}{l}\text { Status } \\
\text { Laag } \\
\text { Midden } \\
\text { Hoog } \\
\text { Totaal }\end{array}$ & $\begin{array}{r}58 \\
33 \\
9 \\
100 \\
\end{array}$ & $\begin{array}{r}57 \\
35 \\
8 \\
100\end{array}$ & & ns \\
\hline
\end{tabular}

Ook is gekeken waar de onderzoeksgroep woonachtig is. Het woongebied is onderverdeeld in drie categorieën, namelijk de provincie Utrecht, de provincies Gelderland en Overijssel en de rest van Nederland. 
In tabel 5.3.1 is te zien dat er duidelijk meer $\left(\chi^{2}=16.51, p=.00, \mathrm{df}=2\right)$ familieleden van hartoperatiepatiënten in Gelderland en Overijssel woonachtig zijn (42\%) dan familieleden van overige intensive care patiënten (20). In de provincie Utrecht wonen meer familieleden van overige intensive care patiënten (45\%) dan familieleden van hartoperatiepatiënten $(22 \%)$. In de rest van Nederland is de verdeling tussen de beide groepen ongeveer gelijk. Dit zou verklaard kunnen worden door het feit dat de provincies Gelderland en Overijssel, voor wat betreft de chirurgische behandeling van hartpatiënten, op Utrecht georiënteerd zijn, terwijl de overige intensive care patiënten uit de provincie Gelderland en Overijssel op de dichtstbijzijnde intensive care worden opgenomen. Dit laatste verklaart ook waarom de meeste familieleden van overige intensive care patiënten in de provincie Utrecht wonen.

De "status" van de familieleden is in dit onderzoek een combinatie van opleiding en beroep. Ten aanzien van de status van de familieleden van intensive care patiënten is in tabel 5.3.1 te zien dat de meeste familieleden uit beide onderzoeksgroepen ( $58 \%$ en $57 \%$ ) een lage status hebben. Dit houdt mogelijk verband met het feit dat de grootste groep respondenten uit vrouwen bestaat uit de leeftijdscategorie ouder dan 41 jaar. Een kleiner percentage familieleden uit beide groepen ( $33 \%$ en $35 \%$ ) heeft een middelbare status en het kleinste aantal uit beide groepen ( $9 \%$ en $8 \%$ ) familieleden hebben een hoge status. Er zijn geen significante verschillen ten aanzien van status gevonden tussen de groep familieleden van hartoperatiepatiënten en de groep familieleden van overige intensive care patiënten.

\subsection{Overzicht intensive care gelieerde variabelen}

In dit onderzoek zijn vijf intensive care gelieerde variabelen betrokken, te weten: (1) de wachttijd voor opname van de patiënt op de intensive care; (2) het eventueel uitgesteld zijn van de opname op de intensive care; (3) de eventuele bekendheid van het familielid met de intensive care; (4) het tijdstip waarop de vragenlijst op de intensive care werd afgenomen bij het familielid en (5) de vraag wat familieleden het minst plezierig vonden op de intensive care (tabel 5.4, 5.4.1 en 5.4.2). In tabel 5.4 is te zien dat $81 \%$ familieleden van hartoperatiepatiënten geconfronteerd zijn met een wachttijd op opname van de patiënt op de intensive care. Opvallend is dat deze situatie duidelijk minder voorkomt $(33 \%)$ bij overige intensive care patiënten $\left(\chi^{2}=48.15 ; \mathrm{p}=.00 ; \mathrm{df}=1\right)$ dan bij hartoperatiepatiënten. Dit verschil zou verklaard kunnen worden door het feit dat de opname-indicatie van een patiënt op een algemene intensive care vaak het karakter van een calamiteit heeft, terwijl patiënten die een hartoperatie moeten ondergaan in Nederland over het algemeen op een wachtlijst geplaatst worden.

Tabel 5.4 Wachttijd en uitstel met betrekking tot de opname op de intensive care (\%).

\begin{tabular}{|c|c|c|c|c|}
\hline & 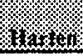 & $z^{6}$ & (1) & 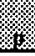 \\
\hline $\begin{array}{l}\text { Wachttijd } \\
\text { Ja } \\
\text { Totaal }\end{array}$ & $\begin{array}{c}(n=100) \\
81 \\
100 \\
\end{array}$ & $\begin{array}{c}(n=106) \\
33 \\
100 \\
\end{array}$ & 1 & .00 \\
\hline $\begin{array}{l}\text { Uitstel } \\
\text { Ja } \\
\text { Totaal }\end{array}$ & $\begin{array}{c}(n=98) \\
14 \\
100\end{array}$ & $\begin{array}{c}(n=106) \\
7 \\
100\end{array}$ & & ns \\
\hline
\end{tabular}


Naast wachttijd op opname is de vraag gesteld of de opname op de intensive care uitgesteld geweest is. Tabel 5.4 laat zien dat 14\% familieleden van hartoperatiepatiënten en $7 \%$ familieleden van overige intensive care patiënten geconfronteerd zijn met uitstel van de opname van de patiënt. Hier lijkt een verschil te bestaan tussen de patiënten op een algemene intensive care en hartoperatiepatiënten. Een duidelijk verschil is echter niet aangetoond.

Een grote groep respondenten ( $58 \%$ familieleden van hartoperatiepatiënten en $63 \%$ familieleden van overige intensive care patiënten) blijkt, zoals in tabel 5.4.1 te zien is, bekend te zijn met een intensive care.

Tabel 5.4.1 Bekendheid met de intensive care en periode van afname van de vragenlijst (\%).

\begin{tabular}{|c|c|c|c|c|}
\hline & 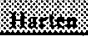 & 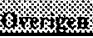 & 楼 & 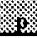 \\
\hline $\begin{array}{l}\text { Bekendheid } \\
\text { Ja } \\
\text { Totaal }\end{array}$ & $\begin{array}{c}(n=100) \\
58 \\
100\end{array}$ & $\begin{array}{c}(n=106) \\
63 \\
100\end{array}$ & & ns \\
\hline $\begin{array}{l}\text { Afnameperiode } \\
0-24 \text { uur } \\
24-48 \text { uur } \\
48-72 \text { uur } \\
\text { Totaal }\end{array}$ & $\begin{array}{c}(\mathrm{n}=100) \\
18 \\
63 \\
19 \\
100\end{array}$ & $\begin{array}{c}(n=106) \\
15 \\
43 \\
42 \\
100\end{array}$ & 2 & .00 \\
\hline
\end{tabular}

De interviews zijn allen afgenomen in de eerste 72 uur van de opname van de patiënt op de intensive care. Zoals tabel 5.4.1 laat zien is de periode waarbinnen de vragenlijsten zijn afgenomen onderverdeeld in drie categorieën, namelijk de eerste 24, de tweede 24 en de derde 24 uur na opname van de patiënt op de intensive care.

De meeste interviews zijn gehouden in de tweede 24 uur van de opname van de patiënt $(63 \%$ bij familieleden van hartoperatiepatiënten en $43 \%$ bij familieleden van overige intensive care patiënten. Dit wordt verklaard door het feit dat, zo snel mogelijk na opname van de patiënt, met alle respondenten een afspraak gemaakt werd voor het interview. Omdat veel respondenten afhankelijk waren van vervoer door derden en daardoor een afspraak moesten maken voor de volgende dag, zijn minder interviews in de eerste 24 uur gehouden ( $18 \%$ familieleden van hartoperatiepatiënten en $15 \%$ familieleden van overige intensive care patiënten).

Opvallend is dat duidelijk meer familieleden van overige intensive care patiënten (42\%) in de derde 24 uur na opname geïnterviewd zijn $\left(\chi^{2}=13.51 ; \mathrm{p}=.00 ; \mathrm{df}=2\right)$ dan familieleden van hartoperatiepatiënten. Dit is enerzijds te verklaren door het feit dat hartoperatiepatiënten, wanneer geen complicaties optreden, meestal binnen 48 uur overgeplaatst kunnen worden naar een verpleegafdeling en daarom eerder geïnterviewd zijn. Anderzijds bleken familieleden van overige intensive care patiënten vaak niet in staat (de patiënt verkeerde in een zeer kritieke situatie) om in de eerste 48 uur na de opname aan het onderzoek mee te werken.

Aan de familieleden is gevraagd of zij een onplezierige ervaring hebben meegemaakt op de intensive care. 
Zoals tabel 5.4.2 toont, is het antwoord "ja"op deze vraag verdeeld in categorieën (patiëntgebonden factoren, te weten: apparatuur en aanblik van de patiënt, medewerkergebonden factoren, te weten: opvang en benadering op de intensive care, informatie en communicatie en organisatiegebonden factoren, te weten: wachttijden en organisatie op de intensive care).

Tabel 5.4.2 Onplezierige ervaring op de intensive care (\%).

\begin{tabular}{|c|c|c|}
\hline & 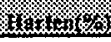 & 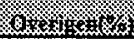 \\
\hline Onplezierige ervaring* & $(n=100)$ & $(n=106)$ \\
\hline $\mathbf{J a}$ & 56 & 55 \\
\hline Patiëntgebonden & 13 & 18 \\
\hline Medewerkergebonden & 11 & $M$ \\
\hline Organisatiegebonden & 28 & 17 \\
\hline Anders & 4 & 9 \\
\hline Totaal & 100 & 100 \\
\hline
\end{tabular}

$J a$

Patiëntgebonden

apparatuur en canblik van de patiënt

Medewerkergebonden

Organisatiegebonden

opvang en benadering, informatie en communicatie

wachttijden en organisatie op de intensive care

In beide onderzoeksgroepen geeft meer dan de helft van de familieleden aan ( $56 \%$ en $55 \%)$ een onplezierige ervaring te hebben gehad. De meeste onplezierige ervaringen zijn organisatiegebonden (wachttijd en organisatie op de intensive care), gevolgd door patiëntgebonden ervaringen (apparatuur en aanblik van de patiënt). Ook medewerkergebonden ervaringen (opvang, benadering, informatie en communicatie) worden in beide groepen genoemd. Duidelijke verschillen tussen beide onderzoeksgroepen zijn echter niet aangetoond.

\subsection{Overzicht ziektegebonden variabelen}

Naast sociaal-demografische en intensive care gelieerde variabelen is gekeken of er een verband kan worden aangetoond tussen ziektegebonden variabelen (het wel of niet gepland zijn van de opname op de intensive care, het wel of niet mechanisch beademd worden van de patiënt op de intensive care, het feit of het een eerste opname van de patiënt op de intensive care betrof, de inschatting van de levensbedreiging van de patiënt door het familielid en de inschatting van de levensbedreiging van de patiënt door een intensive care verpleegkundige) en de opname-indicatie (hartoperatie en overige intensive care indicatie).

Tabel 5.5. toont drie ziektegebonden variabelen (geplande of niet geplande opname, mechanische ventilatie, eerste opname). Opvallend is dat bij de overige intensive care patiënten het aantal geplande opnames $(40 \%)$ significant lager is $\left(\chi^{2}=40.57 ; \mathrm{p}=.00 ; \mathrm{df}=1\right)$ dan bij de hartoperatiepatiënten (83\%). Deze gegevens komen overeen met de, eerder in dit hoofdstuk beschreven wachttijd op opname (tabel 5.4) waaruit blijkt dat overige intensive care patiënten significant minder geconfronteerd worden met een wachttijd op opname.

Ook het feit dat de patiënt geconfronteerd wordt met een niet geplande (spoed) opname op de intensive care zou hier verklaard kunnen worden door het gegeven dat de opname-indicatie van een patiënt op een algemene intensive care meestal een calamiteit betreft, terwijl de opname van een hartoperatiepatiënt in de meeste gevallen gepland is. 
Tabel 5.5 Ziektegebonden variabelen familieleden van intensive care patiënten (\%).

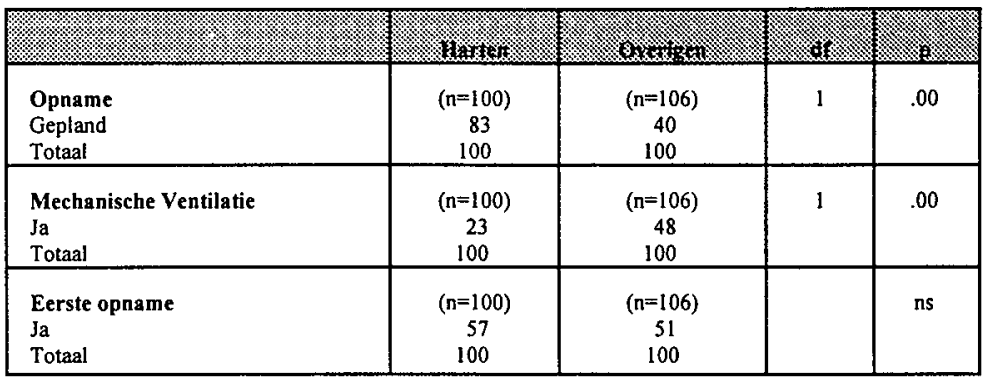

In de groep familieleden van hartoperatiepatiënten werden $23 \%$ patiënten beademd tegenover $48 \%$ overige intensive care patiënten. Hier bestaat een duidelijk $\left(\chi^{2}=14.09 ; p=.00 ; d f=1\right)$ verschil tussen beide onderzoeksgroepen. Overige intensive care patiënten worden vaker mechanisch beademd dan hartoperatiepatiënten. Dit kan mogelijk verklaard worden door het feit dat overige intensive care patiënten frequenter met spoed opgenomen worden op de intensive care en het hier wellicht een meer levensbedreigend ziektebeeld betreft.

Een grote groep patiënten (57\% hartoperatiepatiënten en $51 \%$ overige intensive care patiënten) was voor de eerste keer opgenomen op de intensive care. Er is geen verschil gevonden tussen de beide onderzoeksgroepen (tabel 5.5).

Aan de familieleden werd gevraagd een inschatting te geven van de mate van levensbedreiging waarin de patiënt tijdens de opname op de intensive care verkeerde.

De familieleden werd gevraagd een cijfer tussen de 1 en de 10 te noemen, waarbij het cijfer 1 niet levensbedreigend en het cijfer 10 zeer levensbedreigend vertegenwoordigt (zie tabel 5.5.1). Nadat de cijfers zijn gegeven, is levensbedreiging gecategoriseerd in drie categorieën (niet levensbedreigend (cijfer $1 \mathrm{t} / \mathrm{m}$ 4), levensbedreigend (cijfer $5 \mathrm{t} / \mathrm{m}$ 7) en zeer levensbedreigend (cijfer $8 \mathrm{t} / \mathrm{m} \mathrm{10}$ ). Na de vraag aan de respondenten gesteld te hebben, is dezelfde vraag aan de verpleegkundige die op dat moment de zorg voor de patiënt had gesteld. Zoals in tabel 5.5.2 te zien is hebben 20 verpleegkundigen de vraag niet beantwoord omdat ze op het moment van het interview niet geconsulteerd konden worden.

Meer dan de helft van de familieleden van overige intensive care patiënten, zoals tabel 5.5.1 toont, geeft aan de situatie van de patiënt levensbedreigend (levensbedreigend en zeer levensbedreigend) te vinden (64\%). Hiervan schat $28 \%$ de situatie zeer levensbedreigend in. Opvallend is dat familieleden van hartoperatiepatiënten de situatie van de patiënt duidelijk minder levensbedreigend $\left(\chi^{2}=11.67 ; \mathrm{p}=.00 ; \mathrm{df}=2\right)$ inschatten dan de overige familieleden. Een grote groep (52\%) zegt hier de situatie niet levensbedreigend in te schatten.

De verpleegkundigen schatten de situatie van de patiënt positiever in dan de familieleden. $\mathrm{Bij}$ de groep hartoperatiepatiënten komt de inschatting zeer levensbedreigend niet voor, terwijl dit in de groep overige intensive care patiënten $12 \%$ is. De verpleegkundigen vinden de situatie van de hartoperatiepatiënten over het algemeen niet levensbedreigend (76\%). 
Verpleegkundigen vinden, evenals de familieleden, de situatie van de overige intensive care patiënten duidelijk zorgwekkender $\left(\chi^{2}=22.27 ; \mathrm{p}=.00 ; \mathrm{df}=2\right)$ dan de situatie van de hartoperatiepatiënten ( $43 \%$ schat de situatie levensbedreigend en $12 \%$ zeer levensbedreigend in).

Tabel 5.5.1 Inschatting levensbedreiging door familieleden en intensive care verpleegkundigen (\%).

\begin{tabular}{|l|c|c|c|c|}
\hline (1nschatting door familie & $(\mathrm{n}=99)$ & $(\mathrm{n}=106)$ & 2 & .00 \\
Niet levensbedreigend & 52 & 36 & & \\
Levensbedreigend & 38 & 36 & & \\
Zeer levensbedreigend & 10 & 28 & & \\
Totaal & 100 & 100 & & \\
\hline Inschatting door verpleegkundige & $(\mathrm{n}=86)$ & $(\mathrm{n}=100)$ & 2 & .00 \\
Niet levensbedreigend & 76 & 45 & & \\
Levensbedreigend & 24 & 43 & & \\
Zeer levensbedreigend & 0 & 12 & & \\
Totaal & 100 & 100 & & \\
\hline
\end{tabular}

Niet levensbedreigend $=1 \mathrm{t} / \mathrm{m} 4$

Levensbedreigend $=5 \mathrm{t} / \mathrm{m} 7$

Zeer levensbedreigend $=8 \mathrm{vm} 10$

Om een beter inzicht te krijgen in de toegekende cijfers, zijn in tabel 5.5.2 de gemiddelde cijfers te zien die de familieleden gaven. Het gemiddelde cijfer met betrekking tot levensbedreiging dat de familieleden van hartoperatiepatiënten toekenden is 3.9. Het gemiddelde cijfer dat familieleden van overige intensive care patiënten gaven is 5.3. Duidelijk wordt ook hier dat familieleden van overige intensive care patiënten een significant hoger cijfer geven $(t=3.51 ; p=.00 ; \mathrm{df}=203)$ dan familieleden van hartoperatiepatiënten.

Ook de verpleegkundigen geven de overige intensive care patiënten een significant hoger cijfer met betrekking tot levensbedreiging ( $t=-5.06 ; \mathrm{p}=.00 ; \mathrm{df}=184)$. Tabel 5.5.2 toont dat het gemiddelde cijfer dat intensive care verpleegkundigen toekennen aan overige intensive care patiënten 4.3 is ten opzichte van het cijfer 2.8 voor de hartoperatiepatiënten.

Tabel 5.5.2 Gemiddelde cijfers levensbedreiging door familieleden en intensive care verpleegkundigen.

\begin{tabular}{|c|c|c|c|c|c|}
\hline & 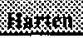 & (2) & 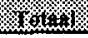 & \% & 8 \\
\hline $\begin{array}{l}\text { Cijfer verpleegkundige } \\
\text { Gemiddelde cijfers }\end{array}$ & $\begin{array}{c}(n=86) \\
2.8\end{array}$ & $\begin{array}{c}(n=100) \\
4.3\end{array}$ & $\begin{array}{c}(n=186) \\
3.5\end{array}$ & 204 & .00 \\
\hline $\begin{array}{l}\text { Cijfer familie } \\
\text { Gemiddelde cijfers }\end{array}$ & $\begin{array}{c}(\mathrm{n}=99) \\
3.9\end{array}$ & $\begin{array}{c}(n=106) \\
5.3\end{array}$ & $\begin{array}{c}(\mathrm{n}=205) \\
4.6\end{array}$ & 184 & .00 \\
\hline
\end{tabular}




\subsection{Overzicht copingstijlen}

Binnen dit onderzoek is gekeken welke copingstijl familieleden van intensive care patiēnten hanteren en of deze van invloed is op de behoeften van familieleden. Voor dit onderzoek is gebruik gemaakt van een verkorte versie van de Utrechtse Coping Lijst (U.C.L.) met 15 items (Janssen et al., in voorbereiding). Hierbij zijn vier copingstijlen te onderscheiden, namelijk (1) "afwachten en vermijden", (2) "palliatief gedrag", (3) "sociale steun zoeken" en (4) "actief het probleem aanpakken". De familieleden hebben op een 4-punt Likertschaal, oplopend van (1) zelden of nooit tot (4) zeer vaak, aangegeven hoe ze over het algemeen reageren bij problemen.

De gemiddelde score op "actief aanpakken" is voor de familieleden van hartoperatiepatiënten 2.9 en voor de familieleden van overige intensive care patiënten 3.0.

Op de copingstijl "sociale steun zoeken" zijn de gemiddelde scores respectievelijk 2.2 en 2.5 . "Afwachten en ver-mijden" geeft een gemiddelde score van 1.9 voor de familieleden van hartoperatiepatiënten en 1.8 voor de familieleden van overige intensive care patiënten. De gemiddelde scores op "palliatief gedrag" zijn 2.3 en 2.2 (zie tabel 5.6).

Geary (1979) deed een exploratieve studie naar copinggedrag van familieleden op de intensive care. Naast haar conclusie dat het gedrag van familieleden varieerde van persoon tot persoon onderscheidde zij 5 copingstijlen, te weten: (1) "minimaliseren", (2) "rationaliseren", (3) "herhalen", (4) "zich sterk en competent gedragen" en (5) "dichtbij de patiënt blijven". "Minimaliseren", de copingstijl die in de studie van Geary (1979) het meest voorkomt, beschrijft zij als de betekenis van de gebeurtenis verkleinen of trachten te negeren. Deze copingstijl kan vergeleken worden met de copingstijlen "palliatief gedrag" en "afwachten en vermijden" in dit onderzoek. Bij vergelijk hebben de copingstijlen "palliatief gedrag" en "afwachten en vermijden", in deze studie, de laagste gemiddelde scores.

Nolan et al., (1992) concluderen in hun studie dat "weten dat onze familie de kracht heeft om problemen op te lossen" de meest gehanteerde copingstijl is.

Dit komt overeen met de resultaten met betrekking tot de copingstijl "actief aanpakken" in dit onderzoek. Familieleden uit het onderzoek van Nolan et al., (1992) scoorden laag op palliatief copinggedrag.

In tabel 5.6 is te zien dat familieleden van hartoperatiepatiënten significant minder vaak sociale steun zoeken dan familieleden van overige intensive care patiënten $(t=-3.12 ; p=.002$; $\mathrm{df}=204)$. Mogelijk houdt dit verband met de preventieve informatieprogramma's die ziekenhuizen, waar hartoperaties worden uitgevoerd, hanteren. Ook de informatie waarmee de Nederlandse Hart Stichting in de media treedt zou hier een rol kunnen spelen. Met betrekking tot de overige copingstijlen zijn geen verschillen tussen de beide onderzoeksgroepen aangetoond. 
Tabel 5.6 Overzicht gemiddelde scores op coping van familieleden van intensive care patienten (\%)

\begin{tabular}{|c|c|c|c|c|}
\hline \% & \% & 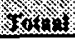 & \% & 证 \\
\hline $\begin{array}{l}\text { Actief aanpakken } \\
\text { Harten } \\
\text { Overigen } \\
\text { Totaal } \\
\end{array}$ & $\begin{array}{c}(n=203) \\
2.9(\text { sd } .55) \\
3.0(\text { sd } .52) \\
3.0(\text { sd } .54) \\
\end{array}$ & $\begin{array}{r}48 \\
52 \\
100 \\
\end{array}$ & & ns \\
\hline $\begin{array}{l}\text { Sociale steun zoeken } \\
\text { Haren } \\
\text { Ovcrigen } \\
\text { Totaal } \\
\end{array}$ & $\begin{array}{c}(n=203) \\
2.2(s d .57) \\
2.5(\text { sd } .60) \\
2.3(\text { sd } .60) \\
\end{array}$ & $\begin{array}{r}48 \\
52 \\
100 \\
\end{array}$ & 201 & .00 \\
\hline $\begin{array}{l}\text { Afwachten en vermijden } \\
\text { Harten } \\
\text { Overigen } \\
\text { Totaal }\end{array}$ & $\begin{array}{l}(n=203) \\
1.9(\mathrm{sd} .56) \\
1.8(\mathrm{sd} .57) \\
1.2(\mathrm{sd} .57)\end{array}$ & $\begin{array}{r}48 \\
52 \\
100 \\
\end{array}$ & & ns \\
\hline $\begin{array}{l}\text { Palliatief gedrag } \\
\text { Harten } \\
\text { Overigen } \\
\text { Totaal }\end{array}$ & $\begin{array}{c}(n=203) \\
2.3(\mathrm{sd} .61) \\
2.2(\mathrm{sd} .65) \\
2.2(\mathrm{sd} .63)\end{array}$ & $\begin{array}{c}48 \\
52 \\
100\end{array}$ & & ns \\
\hline
\end{tabular}

Min score $=1$

Max. score $=4$

\subsection{Kenmerken van familieleden en invloed op behoeften}

Uit de vorige paragrafen blijkt dat verschillende factoren van invloed zijn op behoeften van familieleden. Hierbij is een duidelijk onderscheid te maken tussen familieleden van hartoperatiepatiënten en familieleden van overige intensive care patiënten.

Zowel vanuit theoretisch oogpunt als vanuit het belang voor de verpleegkundige beroepspraktijk op de intensive care, is het van belang te weten of, met behulp van aspectmetingen (logistische regressie analyse methode backward stepwise) met de beïnvloedende variabelen, voor-spellingen gedaan kunnen worden voor specifieke doelgroepen. Op deze wijze kan, wanneer onderscheid bestaat tussen familieleden van hartoperatiepatiënten en familieleden van overige intensive care patiënten, op grond van algemene kenmerken, sneller geanticipeerd worden op de specifieke situatie van familieleden van intensive care patiënten. Ondanks het feit dat het hier slechts een globale benadering van de onafhankelijke variabelen betreft en er geen dominante positie is toe te schrijven aan de op zichzelf staande variabelen in de regressie, zijn uit theoretische en praktische overwegingen profielen ontwikkeld voor familieleden van hartoperatiepatiënten en familieleden van overige intensive care patiënten.

In tabel 5.7 is te zien dat 4 van de 7 beïnvloedende variabelen zijn opgenomen in het model, te weten (1) mechanische beademing, (2) de copingstijl "sociale steun zoeken", (3) het woongebied van het familielid en (4) de wachttijd op opname. Deze kenmerken kunnen gezien worden als de 4 beste voorspellers voor de opname-indicatie van de patiënt. 


\begin{tabular}{|c|c|c|c|c|}
\hline Y stablb & 8 & $2 x$ & 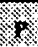 & $n$ \\
\hline $\begin{array}{l}\text { Mechanische beademing } \\
\text { Sociale steul zoeken } \\
\text { Woongebied } \\
\text { Wachetijd } \\
\text { Constant }\end{array}$ & $\begin{array}{r}-.95 \\
-.63 \\
-.61 \\
2.20 \\
.38\end{array}$ & $\begin{array}{l}.35 \\
.33 \\
.33 \\
.35 \\
.38\end{array}$ & $\begin{array}{l}.00 \\
.06 \\
.06 \\
.00 \\
.31\end{array}$ & $\begin{array}{l}-.13 \\
-.07 \\
-.06 \\
.36\end{array}$ \\
\hline
\end{tabular}

Model Chi-square $\times 2=66.94 \mathrm{df}=4 \mathrm{p}=.00$

De variabele "Woongebied" is voor de regressie gedichotomiseerd en bestaat uit twee classen (de provincies Utrecht/Gelderland en de rest van Nederland). Omdat deze studie heeft plaatsgevonden in twee ziekenhuizen in de provincie Utrecht, kunnen twee groepen familieleden onderscheiden worden (1) de groep familieleden die relatief dichtbij het ziekenhuis woont en (2) de groep familieleden die niet dichtbij het ziekenhuis woont.

In tabel 5.7.1 is te zien dat, van de 205 familieleden met bovengenoemde kenmerken, $75 \%$ met indicatie familielid hartoperatiepatiënten en $71 \%$ zonder indicatie familielid hartoperatiepatiënt (familielid overige intensive care patiënt) correct voorspeld kunnen worden door het model van de 4 genoemde variabelen. Van de 205 familieleden wordt $73 \%$ (146 familieleden) in de juiste groep ingedeeld.

\begin{tabular}{|c|c|c|c|}
\hline & Waros & oresigen. & $\%$ cortert \\
\hline Harten & 74 & 25 & $75 \%$ \\
\hline Overigen & 31 & 75 & $71 \%$ \\
\hline Totaal & & & $73 \%$ \\
\hline
\end{tabular}

Vervolgens zijn, met de kenmerken van het familielid waarmee de opname-indicatie voorspeld kan worden, twee profielen samengesteld. Profiel Harten is, in $75 \%$ van de gevallen, het familielid van een patiënt die te maken heeft gehad met een wachttijd op opname en die niet mechanisch beademd wordt. Het familielid woont niet in de provincie Utrecht of Gelderland en scoort relatief laag op de copingstijl "sociale steun zoeken". Profiel Overigen is, in $71 \%$ van de gevallen, het familielid van een patiënt waarbij geen sprake was van wachttijd op opname en mechanisch wordt beademd. Het familielid woont in de provincie Utrecht of Gelderland en scoort relatief hoog op de copingstijl "sociale steun zoeken".

Met behulp van bovengenoemde kenmerken is nogmaals gepoogd een verschil in behoeften tussen familieleden van hartoperatiepatiënten en familieleden van overige intensive care patiënten aan te tonen. Opvallend is dat er een significant verschil optreedt (tabel 5.7.2) bij de ontwikkelde profielen $\mathbf{H}$ en $\mathbf{O}$ (familieleden van hartoperatiepatiënten en familieleden van overige intensive care patiënten), als het gaat om behoeften aan informatie $(\chi=4.50 ; \mathrm{df}=1$; $\mathrm{p}=.03$ ). 
Profiel $\mathbf{O}$ heeft een gemiddelde score van 3.0 op de behoeftecategorie "informatie" ten opzichte van profiel $\mathbf{H}$ die een gemiddelde score heeft van 2.8. Hierbij dient echter opgemerkt te worden dat het slechts om totaal 30 familieleden gaat die in de analyse zijn opgenomen. Bij de overige behoeftecategorieën (ondersteuning, toegankelijkheid en begeleiding) scoren beide profielen over het algemeen gelijk.

Tabel 5.7.2 Invloed van familieprofielen op de behoeften van familieleden

\begin{tabular}{|c|c|c|c|c|}
\hline 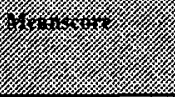 & 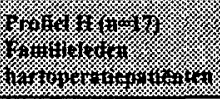 & 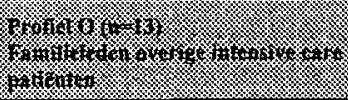 & 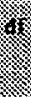 & $\%$ \\
\hline $\begin{array}{l}\text { Informatie } \\
\text { Ondersteuning } \\
\text { Toegankelijkheid } \\
\text { Begeleiding }\end{array}$ & $\begin{array}{l}2.8 \\
2.4 \\
3.4 \\
2.9\end{array}$ & $\begin{array}{l}3.0 \\
2.4 \\
3.4 \\
3.0\end{array}$ & 1 & .03 \\
\hline
\end{tabular}

Min. score $=1$

Max. score $=4$

\subsection{Samenvatting}

In dit hoofdstuk is de invloed van de opname-indicatie van de patiënt (hartoperatie of overige intensive care indicatie) op behoeften van familieleden aan informatie, ondersteuning, toegankelijkheid en begeleiding beschreven. Opname-indicatie van de patiënt heeft geen invloed op behoeften van familieleden. Familieleden vinden toegankelijkheid het meest belangrijk (meanscore 3.5), gevolgd door informatie (meanscore 2.9). De minst belangrijke behoefte is ondersteuning (meanscore van 2.4). Behoeften aan begeleiding, het totaal van de drie hiervoor genoemde behoeftecategorieën heeft een gemiddelde score van 2.9. Familieleden van hartoperatiepatiënten hebben meer te maken met een wachttijd op opname van de patiënten dan familieleden van overige intensive care patiënten. Ook wordt de opname van hartoperatiepatiënten vaker uitgesteld dan bij overige intensive care patiënten. Familieleden van hartoperatiepatiënten zijn vaker geïnterviewd in de eerste 48 uur van de opname van de patiënt op de intensive care dan familieleden van overige intensive care patiënten. De laatste groep blijft, in tegenstelling tot hartoperatiepatiënten, langer op de intensive care zodat ook de derde dag van de opname (tot 72 uur na opname) familieleden geïnterviewd konden worden.

Hartoperatiepatiënten worden vaker gepland opgenomen dan overige intensive care patiënten. Overige intensive care patiënten worden vaker mechanisch beademd.

De mate van levens-bedreiging van de patiënt wordt bij overige intensive care patiënten zowel door de verpleeg-kundige als door de familieleden zelf, ernstiger ingeschat dan bij hartoperatiepatiënten. In beide onderzoeksgroepen schat de familie de mate van levensbedreiging van de patiënt duidelijk ernstiger in dan de verpleegkundige.

Familieleden van overige intensive care patiënten hebben een duidelijk hogere score (2.5) op de copingstijl "sociale steun zoeken" dan familieleden van hartoperatiepatiënten (2.2). De andere copingstijlen ("actief aanpakken", "afwachten en vermijden" en "palliatief gedrag") komen in beide onderzoeksgroepen gelijk voor. 
Tot slot zijn twee profielen ontwikkeld (Harten en Overigen). Profiel $\mathbf{H}$ is het familielid van een patiënt die te maken heeft gehad met een wachttijd op opname, niet mechanisch beademd wordt, niet in de provincie Utrecht of Gelderland woont en relatief weinig sociale steun zoekt. In $75 \%$ van de gevallen betreft het hier familie van een hartoperatiepatiënt.

Profiel $\mathbf{O}$ is het familielid van een patiënt die niet te maken heeft gehad met een wachttijd op opname, beademd wordt, in de provincie Utrecht of Gelderland woont en sociale steun zoekt. In $71 \%$ van de gevallen gaat het hier om familielid van een overige intensive care patiënt. 



\section{RESULTATEN II \\ Behoeften van familieleden en factoren die hierop van invloed zijn}

\subsection{Inleiding}

In dit hoofdstuk wordt de invloed van sociaal-demografische-, intensive care gelieerde-, ziektegebonden- en copingvariabelen op behoeften van familieleden beschreven. Hierbij wordt in eerste instantie gekeken naar invloed op de drie behoeftecategorieën "informatie", "ondersteuning" en "toegankelijkheid".Vervolgens wordt de invloed op de algemene behoeftecategorie "begeleiding" beschreven. De resultaten zullen zowel voor de totale onderzoeksgroep als voor de groep familieleden van hartoperatiepatiënten en de groep familieleden van overige intensive care patiënten steeds afzonderlijk beschreven worden. Alleen de significante resultaten worden beschreven.

Tot slot worden, met behulp van aspectmetingen met beïnvloedende factoren (logistische regressie analyses), voorspellingen gedaan voor specifieke groepen familieleden gericht op behoeftecategorieën. De resultaten worden per behoeftecategorie gepresenteerd.

\subsection{Behoeften van familieleden aan informatie}

De behoefte aan informatie kenmerkt zich, zoals in hoofdstuk 5 al is beschreven, in deze studie als de tweede belangrijke behoefte (meanscore van 2.9) in de behoefte-hiërarchie van drie behoeftecategorieën. In eerdere studies wordt de behoefte aan informatie gekenmerkt als de belangrijkste behoefte van familieleden op de intensive care (Hampe, 1975; Breu en Dracup. 1978; Molter, 1979; Daley, 1984; Bouman, 1984; Mathis, 1984; Chartier \& Coutu-Wakulczyk, 1989; Mclvor en Thompson, 1988; Dockter et al., 1988; McHale en Bellinger, 1988; Norheim, 1989; Forrester et al., 1990; Hickey, 1990; Macey en Bouman, 1991; Price et al. 1991; Freichels, 1991; Murphy et al., 1992; Farrel en Frost, 1992; Kleinpell en Powers, 1992; Henneman et al., 1992; Pender, 1993; Engli en Kirsivali-Farmer, 1993; Foss \& Tenholder, 1993; Warren, 1993; Daly et al, 1994; Davis-Martin, 1994). Omdat deze studies zich over het algemeen beperken tot het beschrijven van behoeften van familieleden, en de eventuele invloed van andere factoren op de behoeften niet of nauwelijks benoemen, wordt gepoogd de resultaten uit deze studie te vergelijken met de resultaten van Daniels et al., (1989) die alleen de invloed van geslacht op de totale score van de C.C.F.N.I. (Molter, 1979) beschrijft en Leske $(1991$, 1992), die de invloed van vijf (sociaal-) demografische factoren op 5 behoeftecategorieën beschrijft, die niet uit dezelfde behoefte-items bestaat als de categorieën uit deze studie.

Omdat Daniels et al., (1989) aantonen dat vrouwen een hogere score hebben op de totale C.C.F.N.I. (Molter, 1979), zou aangenomen kunnen worden dat vrouwen meer behoefte hebben aan informatie dan mannen. Leske $(1991,1992)$ toont aan dat de leeftijd van familieleden, de opname-indicatie van de patiënt en de relatie die familieleden met de patiënt hebben niet van invloed is op de behoefte aan informatie. Vrouwen hebben in de studie van Leske $(1991,1992)$ duidelijk meer behoefte aan informatie dan mannen. Ook de familieleden die niet met een intensive care bekend zijn hebben meer behoefte aan informatie dan de familieleden die eerder met een intensive care te maken hebben gehad. 


\subsubsection{Invloed van sociaal-demografische factoren op behoeften aan informatie}

Zoals uit tabel 6.2.1 valt af te lezen is het geslacht van de familieleden zowel in de totale onderzoeksgroep, $(\mathrm{t}=-2.28 ; \mathrm{df}=201 ; \mathrm{p}=.02)$ als in de groep familieleden van hartoperatiepatiënten $(t=-2.80 ; d f=96 ; p=.00)$ van invloed op de behoeften aan informatie.

Tabel 6.2.1 Invloed van geslacht op de behoeften van familieleden aan informatie (\%)

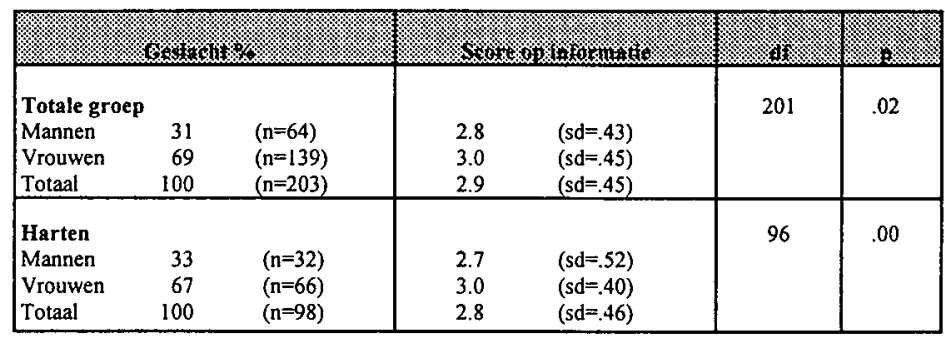

Min. score $=1$

Max. score $=4$

Vrouwen hebben, in beide onderzoeksgroepen, duidelijk meer behoefte aan informatie op de intensive care dan mannen. Dit komt overeen met de resultaten uit de studies van Daniels et al., (1989) en Leske (1991,1992). In de totale onderzoeksgroep hebben vrouwen een gemiddelde score van 3.0 op behoeften aan informatie ten opzichte van 2.8 bij mannen, in de groep familieleden van hartoperatiepatiënten hebben vrouwen een gemiddelde score van 3.0 op behoeften aan informatie ten opzichte van 2.7 bij mannen.

In tegenstelling tot de resultaten van Leske $(1991,1992)$ die aantoont dat de leeftijd van de familieleden niet van invloed is op de behoeften van familieleden aan informatie, is in dit onderzoek de leeftijd van familieleden van invloed op de behoeften aan informatie (tabel 6.2.1.1). Zowel in de totale onderzoeksgroep $\left(\chi^{2}=6.63 ; \mathrm{df}=2 ; \mathrm{p}=.03\right)$ als in de groep familieleden van hartoperatiepatiënten $\left(\chi^{2}=9.06 ; \mathrm{df}=2 ; \mathrm{p}=.01\right)$ hebben familieleden die ouder zijn dan 61 jaar minder behoefte aan informatie dan familieleden die jonger zijn.

In beide onderzoeksgroepen hebben familieleden in de leeftijdscategorieën 20 tot 40 jaar en 41 tot 60 jaar een gemiddelde score van 3.0 op behoeften aan informatie. Familieleden die ouder zijn dan 60 jaar hebben in de groep familieleden uit de totale onderzoeksgroep een score van 2.8 en in de groep familieleden van hartoperatiepatiënten een score van 2.7 op behoeften aan informatie. Het feit dat oudere familieleden (ouder dan 60 jaar) duidelijk minder behoeften aan informatie hebben dan jongere familieleden (tussen de 20 en 60 jaar) is in de groep familieleden van overige intensive care patiënten niet aangetoond. 
Tabel 6.2.1.1 Invloed van leefijd op de behoeften van familieleden aan informatie (\%)

\begin{tabular}{|c|c|c|c|c|c|c|}
\hline \multicolumn{3}{|c|}{ 1/4 } & \multicolumn{2}{|c|}{$64 \%$ \% } & \% & 11 \\
\hline $\begin{array}{l}\text { Totale groep } \\
20-40 \text { jaar } \\
41-60 \text { jaar } \\
>60 \text { jaar } \\
\text { Totaal }\end{array}$ & $\begin{array}{r}28 \\
41 \\
31 \\
100 \\
\end{array}$ & $\begin{array}{l}(n=56) \\
(n=83) \\
(n=64) \\
(n=203)\end{array}$ & $\begin{array}{l}3.0 \\
3.0 \\
2.8 \\
2.9 \\
\end{array}$ & $\begin{array}{l}\text { (sd .36) } \\
\text { (sd .40) } \\
\text { (sd .55) } \\
\text { (sd .45) }\end{array}$ & 2 & .03 \\
\hline $\begin{array}{l}\text { Harten } \\
20-40 \text { jaar } \\
41-60 \text { jaar } \\
>60 \text { jaar } \\
\text { Totaal }\end{array}$ & $\begin{array}{r}31 \\
36 \\
33 \\
100\end{array}$ & $\begin{array}{l}(n=30) \\
(n=35) \\
(n=33) \\
(n=98)\end{array}$ & $\begin{array}{l}3.0 \\
3.0 \\
2.7 \\
2.9\end{array}$ & $\begin{array}{l}\text { (sd .39) } \\
\text { (sd .39) } \\
\text { (sd .53) } \\
\text { (sd .46) }\end{array}$ & 2 & .01 \\
\hline
\end{tabular}

Min. score $=1$

Max. score $=4$

\subsubsection{Invloed van intensive care gelieerde factoren op behoeften aan informatie}

De wachttijd op opname van de patiënt op de intensive care heeft invloed op de behoeften aan informatie in de groep familieleden van overige intensive care patiënten (tabel 6.2.2). Opvallend is dat familieleden van patiënten met een wachttijd op opname gemiddeld lager scoren ( $t=2.00 ; \mathrm{df}=103 ; \mathrm{p}=.04)$ op behoeften aan informatie (2.8) dan familieleden van patiënten zonder wachttijd (3.0). In de totale onderzoeksgroep en in de groep familieleden van hartoperatiepatiënten is deze invloed niet aangetoond.

Tabel 6.2.2 Invloed van wachttijd op opname van de patiënt op de behoeften van familieleden aan informatie (\%)

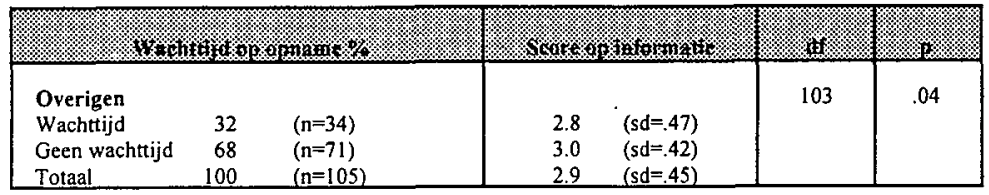

Min. score $=1$

Max. score $=4$

Naast wachttijd op opname speelt ook uitstel van de opname (nadat deze gepland is geweest) een rol bij de behoeften aan informatie $(t=-2.06 ; \mathrm{df}=94 ; \mathrm{p}=.04)$. In de groep familieleden van hartoperatiepatiënten blijkt (tabel 6.2.2.1) dat familieleden van patiënten waarbij de opname is uitgesteld hoger scoren (3.1) op behoeften aan informatie dan familieleden van patiënten waarbij de opname niet is uitgesteld (2.9). 


\begin{tabular}{|c|c|c|c|c|c|c|}
\hline \multicolumn{3}{|c|}{ 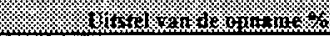 } & Shatix & 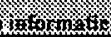 & 器 & x. \\
\hline $\begin{array}{l}\text { Harten } \\
\text { Uitstel } \\
\text { Geen uitstel } \\
\text { Totaal }\end{array}$ & $\begin{array}{r}15 \\
85 \\
100 \\
\end{array}$ & $\begin{array}{l}(n=14) \\
(n=82) \\
(n=96)\end{array}$ & $\begin{array}{l}3.1 \\
2.9 \\
3.0 \\
\end{array}$ & $\begin{array}{l}(s d=.44) \\
(s d=.39) \\
(s d=.44)\end{array}$ & 94 & .04 \\
\hline
\end{tabular}

Min. score $=1$

Max. score $=4$

Een onplezierige ervaring is van invloed $(t=2.10 ; \mathrm{df}=197 ; \mathrm{p}=.04)$ op behoeften aan informatie in de totale onderzoeksgroep (tabel 6.2.2.4). Familieleden die een onplezierige ervaring hebben meegemaakt geven aan meer behoefte te hebben aan informatie (gemiddelde score 3.0) dan familieleden die aangeven geen onplezierige ervaring te hebben gehad (gemiddelde score 2.8). Wanneer deze variabele nader wordt beschouwd, blijkt dat met name een onplezierige ervaring op het gebied van organisatorische aspecten (wachttijd op opname, organisatie van de intensive care zoals bezoektijden) een rol speelt.

Tabel 6.2.2.4 Invloed van een onplezierige ervaring op de behoeften van familieleden aan informatie (\%)

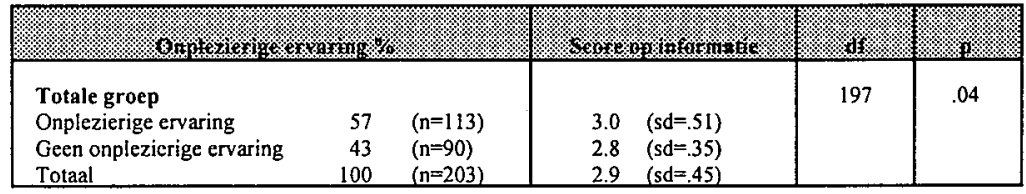

Min. score $=1$

Max. score $=4$

\subsubsection{Invloed van ziektegebonden factoren op behoeften aan informatie}

Van de ziektegebonden factoren heeft alleen de opnamefrequentie (tabel 6.2.3) van de patiënt (het feit dat de patiënt eerder opgenomen is geweest op de intensive care) invloed op de behoeften van familieleden aan informatie. Zowel in de totale onderzoeksgroep $(\mathrm{t}=-2.76$; $\mathrm{df}=201 ; \mathrm{p}=.00)$ als in de groep familieleden van hartoperatiepatiënten $(\mathrm{t}=-2.08 ; \mathrm{df}=96 ; \mathrm{p}=.04)$ blijken familieleden van patiënten die eerder opgenomen zijn geweest op de intensive care een duidelijk hogere score (3.0) te hebben op behoeften aan informatie, dan familieleden van patiënten die voor de eerste keer zijn opgenomen op de intensive care (2.8). Alleen in de groep familieleden van overige intensive care patiënten is dit niet waargenomen. 
Tabel 6.2.3 Invloed van opnamefrequentie op de behoeften van familieleden aan informatie

\begin{tabular}{|c|c|c|c|c|c|c|}
\hline \multicolumn{3}{|c|}{ 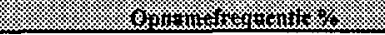 } & \multicolumn{2}{|c|}{ (1) } & 好 & se. \\
\hline $\begin{array}{l}\text { Totale groep } \\
\text { Eerste opname } \\
\text { Meerdere opnames } \\
\text { Totaal }\end{array}$ & $\begin{array}{r}54 \\
46 \\
100 \\
\end{array}$ & $\begin{array}{l}(n=110) \\
(n=93) \\
(n=203)\end{array}$ & $\begin{array}{l}2.8 \\
3.0 \\
2.9 \\
\end{array}$ & $\begin{array}{l}(\mathrm{sd}=.44) \\
(\mathrm{sd}=.44) \\
(\mathrm{sd}=.45)\end{array}$ & 201 & .00 \\
\hline $\begin{array}{l}\text { Harten } \\
\text { Eerste opname } \\
\text { Meerdere opnames } \\
\text { Totaal }\end{array}$ & $\begin{array}{r}58 \\
42 \\
100\end{array}$ & $\begin{array}{l}(n=57) \\
(n=41) \\
(n=98)\end{array}$ & $\begin{array}{l}2.8 \\
3.0 \\
2.9\end{array}$ & $\begin{array}{l}(\mathrm{sd}=.48) \\
(\mathrm{sd}=.41) \\
(\mathrm{sd}=.46)\end{array}$ & 96 & .04 \\
\hline
\end{tabular}

Min. score $=I$

Max. score $=4$

Leske (1991,1992) heeft een verschil gevonden met betrekking tot de bekendheid van de familieleden met de intensive care. Zij toont aan dat familieleden die niet bekend zijn met de intensive care meer behoefte hebben aan informatie dan familieleden die wel bekend zijn. Dit verschil is in deze studie niet aangetoond.

\subsubsection{Invloed van copingstijlen op behoeften aan informatie}

Van de vier copingstijlen zijn alleen de copingstijlen "sociale steun zoeken" en "actief aanpakken" van invloed op de behoeften van familieleden aan informatie. Beide copingstijlen worden in hoofdstuk 2 beschreven als effectief copinggedrag. Hieruit zou kunnen worden afgeleid dat familieleden die behoeften belangrijk vinden eerder geneigd zijn tot een effectieve copingstijl dan familieleden die behoeften minder belangrijk vinden. Andersom geredeneerd kan het zo zijn dat familieleden die geneigd zijn tot effectief copinggedrag meer belang hechten aan behoeften op de intensive care dan familieleden die ineffectief copinggedrag prefereren.

In tabel 6.2 .4 is te zien dat in de totale onderzoeksgroep $(t=2.93 ; \mathrm{df}=201 ; \mathrm{p}=.00)$ en in de groep familieleden van overige intensive care patiënten $(t=2.77 ; \mathrm{df}=103 ; \mathrm{p}=.00)$ respondenten met een hogere score op de copingstijl "sociale steun zoeken" meer behoefte hebben aan informatie (gemiddelde score van 3.0 op behoeften aan informatie) dan respondenten met een lagere score op de copingstijl "sociale steun zoeken" (gemiddelde score van 2.8 op behoeften aan informatie). 
Invloed van de copingstijl "sociale steun zoeken" op de behoeften van familieleden aan informatie (\%)

\begin{tabular}{|c|c|c|c|c|c|c|}
\hline \multicolumn{3}{|c|}{ 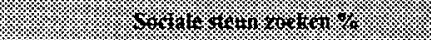 } & \multicolumn{2}{|c|}{ 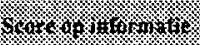 } & 1 & $\%$ \\
\hline $\begin{array}{l}\text { Totale groep } \\
\text { Meanscore } \\
\geq \text { meanscore } \\
<\text { meanscore } \\
\text { Totaal }\end{array}$ & $\begin{array}{r}50 \\
50 \\
100\end{array}$ & $\begin{array}{l}(2.3, s d=60) \\
(n=101) \\
(n=102) \\
(n=203)\end{array}$ & $\begin{array}{l}3.0 \\
2.8 \\
2.9\end{array}$ & $\begin{array}{l}(s d=.44) \\
(s d=.45) \\
(s d=.45)\end{array}$ & 201 & .00 \\
\hline $\begin{array}{l}\text { Overigen } \\
\text { Meanscore } \\
\text { \& meanscore } \\
\text { < meanscore } \\
\text { Totaal }\end{array}$ & $\begin{array}{r}56 \\
44 \\
100\end{array}$ & $\begin{array}{l}(2.5, s d=60) \\
(n=59) \\
(n=46) \\
(n=105)\end{array}$ & $\begin{array}{l}3.0 \\
2.8 \\
2.9\end{array}$ & $\begin{array}{l}(s d=.44) \\
(s d=.42) \\
(s d=.45)\end{array}$ & 103 & .00 \\
\hline
\end{tabular}

Min. score $=1$

Max.score $=4$

De copingstijl "actief aanpakken" is alleen van invloed in de groep familieleden van overige intensive care patiënten. In tabel 6.2.4.1 is te zien dat familieleden met een hogere score op de copingstijl "actief aanpakken", een duidelijk hogere $(t=2.18 ; \mathrm{df}=103 ; \mathrm{p}=.03)$ score op behoeften aan informatie hebben (3.0) dan familieleden met een lagere score op de copingstijl "actief aanpakken". De laatste groep scoort gemiddeld 2.8 op behoeften aan informatie.

Tabel 6.2.4.1 Invloed van de copingstijl "actief aanpakken" op de behoeften van familieleden aan informatie (\%)

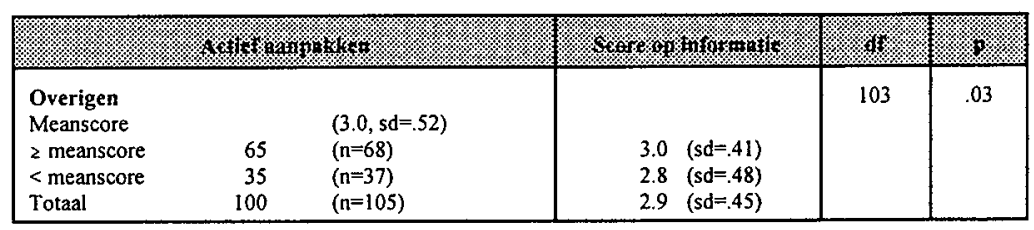

Min. score $=1$

Max score $=4$

Bovengenoemde resultaten steunen het veronderstelde effect (hoofdstuk 2, tabel 2.5.2.1) van de copingstijl "actief aanpakken" op behoeften aan informatie. Duidelijk wordt dat de copingstijlen "actief aanpakken" of "sociale steun zoeken", een positief effect laten zien op behoeften aan informatie. Hieruit zou kunnen worden geconcludeerd dat deze copingstijlen als effectief gedrag kunnen worden gekenmerkt als het gaat om behoeften aan informatie.

\subsubsection{Samenvatting}

In de voorgaande paragrafen is de invloed van sociaal-demografische-, intensive care gelieerde-, ziektegebonden- en copingvariabelen op behoeften aan informatie beschreven. In de totale onderzoeksgroep blijkt dat vrouwen meer behoeften hebben aan informatie dan mannen. Het meemaken van een onplezierige ervaring leidt eveneens tot een grotere behoefte aan informatie. Ook wanneer patiënten eerder op de intensive care opgenomen zijn geweest, heeft dit positieve gevolgen voor de behoeften van familieleden aan informatie. 
Familieleden die een relatief hoge score op de copingstijl "sociale steun zoeken" hebben, geven aan meer behoeften aan informatie te hebben dan familieleden die lager scoren op de copingstijl "sociale steun zoeken".

In de groep familieleden van hartoperatiepatiënten hebben vrouwen meer behoeften aan informatie dan mannen. Uitstel van de opname leidt, evenals een onplezierige ervaring, tot meer behoeften aan informatie. Meerdere opnames van de patiënt op de intensive care heeft eveneens een grotere behoefte aan informatie tot gevolg bij de familieleden.

In de groep familieleden van overige intensive care patiënten hebben familieleden die niet met een wachttijd op opname te maken hebben gehad meer behoeften aan informatie dan familieleden die wel met een wachttijd zijn geconfronteerd. Een relatief hoge score op de copingstijlen "sociale steun zoeken" en "actief aanpakken" leiden in deze groep familieleden tot een toename van de behoeften aan informatie.

\subsection{Behoeften van familieleden aan ondersteuning}

De behoeften van familieleden aan ondersteuning op de intensive care kenmerkt zich als de minst belangrijke behoefte van familieleden (gemiddelde score 2.4, sd .58). Dit komt overeen met resultaten uit eerdere studies (Hampe, 1975; Molter, 1979; McGregor et al, 1981; Yoder en Jones, 1982; Bozett et al., 1983; Daley, 1984; O'Neill-Norris en Grove, 1986; Mclvor en Thompson, 1988; Dockter et al., 1988; McHale en Bellinger, 1988; Liddle, 1988; Norheim, 1989; Chartier \& Coutu Wakulezyk, 1989; Forrester et al., 1990; Price et al., 1991; Freichels, 1991; Koller, 1991; Titler \& Walsh, 1992; Farrel en Frost, 1992; Henneman et al., 1992; McHaffie, 1993;Pender, 1993; Biley et al., 1993).

\subsubsection{Invloed van sociaal-demografische factoren op behoeften aan ondersteuning}

Het geslacht van de familieleden (tabel 6.3.1) is van invloed op de behoeften van familieleden aan ondersteuning op de intensive care. In de totale onderzoeksgroep $(t=-2.08 ; \mathrm{df}=201 ; \mathrm{p}=.04)$ blijkt dat vrouwen een duidelijk hoger score hebben (2.4) op behoeften aan ondersteuning dan mannen (2.2). Dit komt overeen met de resultaten van Daniels et al., (1989) die de invloed van geslacht aantoont voor de totale vragenlijst (vrouwen hebben meer behoeften dan mannen) en Leske (1991,1992) die aantoont dat vrouwen meer behoefte hebben aan ondersteuning dan mannen. In de afzonderlijke groepen familieleden van hartoperatiepatiënten en overige intensive care patiënten is dit verschil niet aangetoond.

Tabel 6.3.1 Invloed van geslacht op de behoeften van familieleden aan ondersteuning (\%)

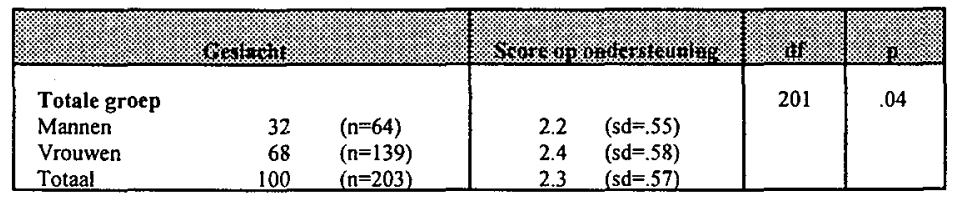

Min. score $=1$

Max. score $=4$ 
Ook het feit of familieleden gelovig zijn (tabel 6.3.1.1) is van invloed op de behoeften aan ondersteuning. In de totale onderzoeksgroep $(t=3.22 ; \mathrm{df}=201 ; \mathrm{p}=.00)$ en in de groep familieleden van overige intensive care patiënten $(t=2.96 ; \mathrm{df}=102 ; \mathrm{p}=.00)$ blijkt dat familieleden die gelovig zijn, duidelijk meer behoeften aan ondersteuning hebben dan familieleden die niet gelovig zijn. In de totale onderzoeksgroep hebben de familieleden die gelovig zijn een gemiddelde score van 2.4 op behoeften aan ondersteuning ten opzichte van 2.2 bij familieleden die niet gelovig zijn. In de groep familieleden van overige intensive care patiënten is de gemiddelde score eveneens 2.4 bij familieleden die gelovig zijn ten opzichte van 2.1 bij familieleden die niet gelovig zijn. In de groep familieleden van hartoperatiepatiënten is dit verschil niet aangetoond (tabel 6.3.1.1). Hierbij dient echter opgemerkt te worden dat het behoefteitem "behoefte aan ondersteuning door een pastoraal medewerker op de intensive care" in de behoeftecategorie "ondersteuning" een beïnvloedende rol speelt. In de totale groep wordt de invloed van geloof op behoeften aan ondersteuning kleiner $(\mathrm{p}=.03)$, in de groep familieleden van overige intensive care patiënten is geen sprake meer van invloed $(p=.1)$.

Tabel 6.3.1.1 Invloed van religie op de behoeften van familieleden aan ondersteuning (\%)

\begin{tabular}{|c|c|c|c|c|c|c|}
\hline \multicolumn{3}{|c|}{ s. } & \multicolumn{2}{|c|}{ 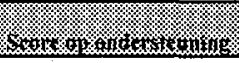 } & 祖 & 玨 \\
\hline $\begin{array}{l}\text { Totale groep } \\
\text { Gelovig } \\
\text { Niet gelovig } \\
\text { Totaal }\end{array}$ & $\begin{array}{r}70 \\
30 \\
100\end{array}$ & $\begin{array}{l}(n=141) \\
(n=62) \\
(n=203)\end{array}$ & $\begin{array}{l}2.4 \\
2.2 \\
2.3\end{array}$ & $\begin{array}{l}(\mathrm{sd}=.59) \\
(\mathrm{sd}=.49) \\
(\mathrm{sd}=.57)\end{array}$ & 201 & .00 \\
\hline $\begin{array}{l}\text { Overigen } \\
\text { Gelovig } \\
\text { Niet gelovig } \\
\text { Totaal }\end{array}$ & $\begin{array}{r}65 \\
35 \\
100\end{array}$ & $\begin{array}{l}(n=68) \\
(n=36) \\
(n=104)\end{array}$ & $\begin{array}{l}2.4 \\
2.1 \\
2.2\end{array}$ & $\begin{array}{l}(\mathrm{sd}=.61) \\
(\mathrm{sd}=.45) \\
(\mathrm{sd}=.58)\end{array}$ & 102 & .00 \\
\hline
\end{tabular}

Min. score $=1$

Max. score $=4$

\subsubsection{Invloed van ziektegebonden factoren op behoeften aan ondersteuning}

De mate van levensbedreiging waarin de patiënt volgens familieleden verkeert, is van invloed op de behoeften aan ondersteuning. In tabel 6.3.2 is te zien dat in de totale onderzoeksgroep $\left(\chi^{2}=8.96 ; \mathrm{df}=2 ; \mathrm{p}=.01\right)$ en in de groep familieleden van overige intensive care patiënten $\left(\chi^{2}=11.29 ; \mathrm{df}=2 ; \mathrm{p}=.00\right)$ familieleden die de toestand van de patiënt zeer levensbedreigend inschatten meer behoeften hebben aan ondersteuning, dan familieleden die de toestand van de patiënt niet zeer levensbedreigend inschatten. In de totale onderzoeksgroep hebben familieleden die de situatie van de patiënt zeer levensbedreigend inschatten een score van 2.5 op behoeften aan ondersteuning ten opzichte van 2.3 bij familieleden die de situatie niet zeer levensbedreigend inschatten. In de groep familieleden van overige intensive care patiënten is dit verschil nog groter, hier scoren familieleden die de situatie zeer levensbedreigend inschatten 2.6 op behoeften aan ondersteuning ten opzichte van $2.2 \mathrm{bij}$ familieleden die de situatie niet zeer levensbedreigend inschatten. Dit verschil is niet aangetoond bij de groep familieleden van hartoperatiepatiënten. 
Tabel 6.3.2 Invloed van ingeschatte levensbedreiging van de patiënt op de behoeften van familieleden aan ondersteuning (\%)

\begin{tabular}{|c|c|c|c|c|c|c|}
\hline \multicolumn{3}{|c|}{ 3 ' } & \multicolumn{2}{|c|}{ - } & 淁 & h \\
\hline $\begin{array}{l}\text { Totale groep } \\
\text { Niet levensbedreigend } \\
\text { Levensbedreigend } \\
\text { Zeer levensbedreigend } \\
\text { Totaal }\end{array}$ & $\begin{array}{r}43 \\
37 \\
20 \\
100 \\
\end{array}$ & $\begin{array}{l}(n=87) \\
(n=75) \\
(n=40) \\
(n=202)\end{array}$ & $\begin{array}{l}2.3 \\
2.3 \\
2.5 \\
2.4 \\
\end{array}$ & $\begin{array}{l}(\mathrm{sd}=.56) \\
(\mathrm{sd}=.61) \\
(\mathrm{sd}=.51) \\
(\mathrm{sd}=.57)\end{array}$ & 2 & .01 \\
\hline $\begin{array}{l}\text { Overigen } \\
\text { Niet levensbedreigend } \\
\text { Levensbedreigend } \\
\text { Zeer levensbedreigend } \\
\text { Totaal }\end{array}$ & $\begin{array}{r}35 \\
36 \\
29 \\
100\end{array}$ & $\begin{array}{l}(n=37) \\
(n=37) \\
(n=30) \\
(n=104)\end{array}$ & $\begin{array}{l}2.2 \\
2.2 \\
2.6 \\
2.3\end{array}$ & $\begin{array}{l}(s d=.63) \\
(s d=.59) \\
(s d=.43) \\
(s d=.59)\end{array}$ & 2 & .00 \\
\hline
\end{tabular}

Min. score $=1$

Max. score $=4$

Of de patiënt mechanisch beademd wordt of zelfstandig ademt, beïnvloedt de behoeften aan ondersteuning van familieleden in de totale onderzoeksgroep $(t=2.01 ; \mathrm{df}=201 ; \mathrm{p}=.04)$ en in de groep familieleden van overige intensive care patiënten $(t=3.08 ; \mathrm{df}=102 ; \mathrm{p}=.00)$.

In tabel 6.3.2.1 is te zien dat familieleden van patiënten die mechanisch beademd worden een hogere score hebben op behoeften aan ondersteuning dan familieleden van patiënten die spontaan ademhalen. In de totale onderzoeksgroep is dat gemiddeld 2.5 ten opzichte van 2.3 in de groep familieleden van overige intensive care patiënten is dat gemiddeld 2.5 ten opzichte van 2.2 .

Tabel 6.3.2.1 Invloed van mechanische beademing op de behoeften van familieleden aan ondersteuning (\%)

\begin{tabular}{|c|c|c|c|c|c|c|}
\hline \multicolumn{3}{|c|}{ 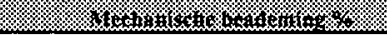 } & \multicolumn{2}{|c|}{ 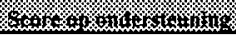 } & 征纹 & 8 \\
\hline $\begin{array}{l}\text { Totale groep } \\
\text { Beademd } \\
\text { Niet beademd } \\
\text { Totaal }\end{array}$ & $\begin{array}{r}36 \\
64 \\
100 \\
\end{array}$ & $\begin{array}{l}(n=74) \\
(n=129) \\
(n=203)\end{array}$ & $\begin{array}{l}2.5 \\
2.3 \\
2.4 \\
\end{array}$ & $\begin{array}{l}(\mathrm{sd}=.53) \\
(\mathrm{sd}=.59) \\
(\mathrm{sd}=.57)\end{array}$ & 201 & .04 \\
\hline $\begin{array}{l}\text { Overigen } \\
\text { Beademd } \\
\text { Niet beademd } \\
\text { Totaal }\end{array}$ & $\begin{array}{r}49 \\
51 \\
100\end{array}$ & $\begin{array}{l}(n=51) \\
(n=53) \\
(n=104)\end{array}$ & $\begin{array}{l}2.5 \\
2.2 \\
2.3\end{array}$ & $\begin{array}{l}(s d=.57) \\
(s d=.56) \\
(s d=.59)\end{array}$ & 102 & .00 \\
\hline
\end{tabular}

Min. score $=1$

Max. score $=4$

\subsubsection{Invloed van copingstijlen op behoeften aan ondersteuning}

Alle copingstijlen zijn van invloed op behoeften aan ondersteuning. Opvallend is dat alleen de copingstijl "actief aanpakken" leidt tot reductie van de behoefte aan ondersteuning. Zoals in hoofdstuk 2 wordt beschreven, wordt deze copingstijl gekenmerkt als effectief copinggedrag. 
Dit gedrag zou tot gevolg kunnen hebben dat familieleden zelf in staat zijn om de voorwaarden te scheppen voor ondersteuning zodat deze behoefte op de intensive care afneemt.

De andere drie, door de familieleden, geprefereerde copingstijlen leiden tot toename van behoeften aan ondersteuning. Hierbij dient te worden opgemerkt dat familieleden die geneigd zijn tot "sociale steun zoeken" verondersteld effectief gedrag vertonen, terwijl familieleden die "palliatief gedrag" vertonen of "afwachten en vermijden" verondersteld ineffectief gedrag vertonen. In alle gevallen dient echter geanticipeerd te worden op de toename van behoeften, terwijl het gedrag van familieleden deze behoeften niet altijd en/of duidelijk kenbaar maken.

De copingstijl "actief aanpakken" is, zoals tabel 6.3 .3 toont, van invloed in de totale onderzoeksgroep ( $\mathrm{t}=-2.27 ; \mathrm{df}=201 ; \mathrm{p}=.02$ ) en in de groep familieleden van hartoperatiepatiënten $(\mathrm{t}=-2.95 ; \mathrm{df}=97 ; \mathrm{p}=.00)$. Uit tabel 6.3 .3 valt af te lezen dat familieleden uit de totale onderzoeksgroep met een score op de copingstijl "actief aanpakken" die hoger is dan de gemiddelde score, minder behoeften hebben aan ondersteuning (gemiddelde score van 2.3 op behoeften aan ondersteuning) dan familieleden met een lagere score op de copingstijl "actief aanpakken" (gemiddelde score van 2.5 op behoeften aan ondersteuning). Ook in de groep familieleden van hartoperatiepatiënten is de gemiddelde score op behoeften aan ondersteuning hoger (2.6) bij familieleden met een lage score op "actief aanpakken" dan bij familieleden met een hogere score op deze copingstijl ( 2.3 op behoeften aan ondersteuning).

Tabel 6.3.3 Invloed van de copingstijl "actief aanpakken" op de behoeften van familieleden aan ondersteuning (\%)

\begin{tabular}{|c|c|c|c|c|c|c|}
\hline \multicolumn{3}{|c|}{ 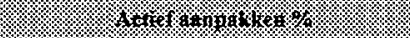 } & \multicolumn{2}{|c|}{ 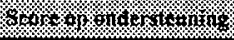 } & \% & 致 \\
\hline $\begin{array}{l}\text { Totale groep } \\
\text { Meanscore } \\
2 \text { meanscore } \\
<\text { meanscore } \\
\text { Totaal }\end{array}$ & $\begin{array}{r}63 \\
37 \\
100\end{array}$ & $\begin{array}{l}(3.0, s d=63) \\
(n=127) \\
(n=76) \\
(n=203)\end{array}$ & $\begin{array}{l}2.3 \\
2.5 \\
2.4\end{array}$ & $\begin{array}{l}(\mathrm{sd}=.58) \\
(\mathrm{sd}=.55) \\
(\mathrm{sd}=.57)\end{array}$ & 201 & .02 \\
\hline $\begin{array}{l}\text { Harten } \\
\text { Meanscore } \\
\text { z meanscore } \\
\text { < meanscore } \\
\text { Totaal }\end{array}$ & $\begin{array}{r}60 \\
40 \\
100\end{array}$ & $\begin{array}{l}(2.9, s d=.56) \\
(n=59) \\
(n=40) \\
(n=99)\end{array}$ & $\begin{array}{l}2.3 \\
2.6 \\
2.4\end{array}$ & $\begin{array}{l}(\mathrm{sd}=.54) \\
(\mathrm{sd}=.55) \\
(\mathrm{sd}=.56)\end{array}$ & 97 & .00 \\
\hline
\end{tabular}

Min. score $=1$

Max. score $=4$

De copingstijl "palliatief gedrag" is, evenals de copingstijl "actief aanpakken" van invloed in de groep familieleden van hartoperatiepatiënten $(t=2.87 ; \mathrm{df}=97 ; \mathrm{p}=.00)$.

In tabel 6.3.3.1 is te zien dat familieleden van hartoperatiepatiënten die een hogere score hebben op de copingstijl "palliatief gedrag" duidelijk meer behoeften hebben aan ondersteuning (gemiddelde score is 2.5 ), dan familieleden met een lagere score op de copingstijl "palliatief gedrag" (gemiddelde score van 2.2 op behoeften aan ondersteuning). 
Tabel 6.3.3.1 Invloed van de copingstijl "palliatief gedrag" op de behoeften van familieleden aan ondersteuning (\%)

\begin{tabular}{|c|c|c|c|c|c|c|}
\hline \multicolumn{3}{|c|}{ \%) } & \multicolumn{2}{|c|}{ 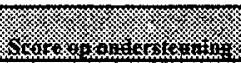 } & 2 & 终 \\
\hline $\begin{array}{l}\text { Harten } \\
\text { Meanscore } \\
\text { 2 meanscore } \\
\text { < meanscore } \\
\text { Totaal }\end{array}$ & $\begin{array}{r}51 \\
49 \\
100\end{array}$ & $\begin{array}{l}(2.3, s d=.62) \\
(n=51) \\
(n=48) \\
(n=99)\end{array}$ & $\begin{array}{l}2.5 \\
2.2 \\
2.3\end{array}$ & $\begin{array}{l}(s d=.49) \\
(s d=.60) \\
(s d=.56)\end{array}$ & 97 & .00 \\
\hline
\end{tabular}

Min. score $=I$

Max. score $=4$

De copingstijl "afwachten en vermijden" beïnvloedt behoeften aan ondersteuning in de totale onderzoeksgroep $(t=2.03 ; \mathrm{df}=201 ; \mathrm{p}=.04)$. Familieleden met een hogere score op de copingstijl "afwachten en vermijden" hebben meer behoeften (tabel 6.3.3.2) aan ondersteuning (gemiddelde score van 2.4) dan familieleden met een lagere score op de copingstijl "afwachten en vermijden" (gemiddelde score van 2.2).

Tabel 6.3.3.2 Invloed van de copingstijl "afwachten en vermijden" op de behoeften van familieleden aar ondersteuning (\%)

\begin{tabular}{|c|c|c|c|c|c|c|}
\hline 8 & $x$ & (3) & \% & (4) & , 14 & 8 \\
\hline $\begin{array}{l}\text { Totale groep } \\
\text { Meanscore } \\
\geq \text { meanscore } \\
<\text { meanscore } \\
\text { Totaal }\end{array}$ & $\begin{array}{r}49 \\
51 \\
100 \\
\end{array}$ & $\begin{array}{l}(1.9, s d=.57) \\
(n=100) \\
(n=1.03) \\
(n=203)\end{array}$ & $\begin{array}{l}2.4 \\
2.2 \\
2.3 \\
\end{array}$ & $\begin{array}{l}(\mathrm{sd}=.54) \\
(\mathrm{sd}=.59) \\
(\mathrm{sd}=.57)\end{array}$ & 201 & .04 \\
\hline
\end{tabular}

Min. score $=1$

Max, score $=4$

Ook de laatste copingstijl, "sociale steun zoeken" beïnvloedt behoeften aan ondersteuning (tabel 6.3.3.3). Opvallend is hier dat deze invloed alleen in de totale onderzoeksgroep $(t=2.34 ; \mathrm{df}=201 ; \mathrm{p}=.02)$ en in de groep familieleden van overige intensive care patiënten $(t=2.04 ; \mathrm{df}=102 ; \mathrm{p}=.04)$ te zien is. In de groep familieleden van hartoperatiepatienten is geen invloed gevonden.

In beide groepen (totaal en overigen) is te zien (tabel 6.3.3.3) dat familieleden met een hogere score op de copingstij1 "sociale steun zoeken" duidelijk meer ondersteuning vragen (gemiddelde score is 2.5 en 2.4) dan familieleden met een lagere score op de copingstij1 "sociale steun zoeken" (gemiddelde score is in beide groepen 2.2 op behoeften aan ondersteuning). 
Tabel 6.3.3.3 Invloed van de copingstijl "sociale steun zoeken" op de behoeften van familieleden aan ondersteuning (\%)

\begin{tabular}{|c|c|c|c|c|c|c|}
\hline \multicolumn{3}{|c|}{ - } & \multicolumn{2}{|c|}{ 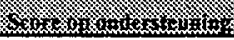 } & mix & 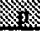 \\
\hline $\begin{array}{l}\text { Totale groep } \\
\text { Meanscore } \\
2 \text { meanscore } \\
<\text { meanscore } \\
\text { Totaal }\end{array}$ & $\begin{array}{r}50 \\
50 \\
100 \\
\end{array}$ & $\begin{array}{l}(2.3, s d=60) \\
(n=101) \\
(n=102) \\
(n=203)\end{array}$ & $\begin{array}{l}2.5 \\
2.2 \\
2.4\end{array}$ & $\begin{array}{l}(s d=.54) \\
(s d=.60) \\
(s d=.57)\end{array}$ & 201 & .02 \\
\hline $\begin{array}{l}\text { Overigen } \\
\text { Meanscore } \\
\text { z meanscore } \\
\text { < meanscore } \\
\text { Totaal }\end{array}$ & $\begin{array}{r}57 \\
43 \\
100\end{array}$ & $\begin{array}{l}(2.5, s d=.60) \\
(n=59) \\
(n=45) \\
(n=104)\end{array}$ & $\begin{array}{l}2.4 \\
2.2 \\
2.3\end{array}$ & $\begin{array}{l}(s d=.59) \\
(s d=.56) \\
(s d=.59)\end{array}$ & 102 & .04 \\
\hline
\end{tabular}

Min. score $=1$

Max. score $=4$

Bovengenoemde resultaten komen gedeeltelijk overeen met het veronderstelde effect van copinggedrag van familieleden op de behoeften aan ondersteuning (hoofdstuk 2, tabel 2.5.2.1). Met name de copingstijlen "actief aanpakken"en "sociale steun zoeken" hebben het veronderstelde effect op behoeften aan ondersteuning op de intensive care. Voor wat betreft het effect van de copingstijlen "afwachten en vermijden" en "palliatief gedrag" blijkt dat familieleden die dit gedrag hanteren eveneens een toename ervaren van behoeften aan ondersteuning echter het beoogde effect (het krijgen van ondersteuning op de intensive care) zal door dit gedrag niet bewerkstelligd worden. Derhalve kan dit gedrag aangemerkt worden als ineffectief copinggedrag.

\subsubsection{Samenvatting}

In de voorgaande paragrafen is de invloed van sociaal-demografische-, ziektegebonden-, intensive care gelieerde- en copingvariabelen op behoeften aan ondersteuning beschreven. In de totale onderzoeksgroep blijkt dat vrouwen meer behoeften aan ondersteuning hebben dan mannen. Familieleden die gelovig zijn hebben meer behoeften aan ondersteuning dan familieleden die niet gelovig zijn. Mechanische beademing van de patiënt heeft een positieve invloed op behoeften aan ondersteuning bij familieleden.

Een relatief hoge score op de copingstijl "sociale steun zoeken" (groter of gelijk aan de gemiddelde score) leidt tot een toename van behoeften aan ondersteuning. In de groep familieleden van hartoperatiepatiënten heeft een relatief hoge score op de copingstijlen "actief aanpakken" en "palliatief gedrag" een positief effect op behoeften aan ondersteuning.

In de groep familieleden van overige intensive care patiënten blijkt dat familieleden die gelovig zijn meer behoeften hebben aan ondersteuning dan familieleden die niet gelovig zijn. Wanneer de patiënt mechanisch beademd wordt hebben familieleden meer behoeften aan ondersteuning dan wanneer de patiënt niet mechanisch beademd wordt. Een relatief hoge score op de copingstijl "sociale steun zoeken" leidt in deze groep tot een toename van behoeften aan ondersteuning. 


\subsection{Behoeften van familieleden aan toegankelijkheid}

Behoeften aan toegankelijkheid dient met name gezien te worden als een behoeftedimensie die zich richt op de voorwaarden die noodzakelijk zijn om in bepaalde behoeften te kunnen voorzien (hoofdstuk 2).

In geen van de eerder genoemde studies wordt deze voorwaarde als zodanig beschreven. Wel is het zo dat behoeften op het gebied van bezoekregelingen en structuur op het gebied van informatie in de literatuur als belangrijke behoefte-items worden opgemerkt (McGregor, Fuller \& Lee, 1981; Henneman et al., 1992).

\subsubsection{Invloed van sociaal-demografische factoren op behoeften aan toegankelijkheid}

Het geslacht van het familielid en de relatie die het familielid met de patiënt heeft, zijn van invloed op de behoeften aan toegankelijkheid op de intensive care. Deze bevindingen komen gedeeltelijk overeen met de resultaten uit de Verenigde Staten van Amerika en het Verenigd Koninkrijk waar met name aangetoond is dat vrouwen in het algemeen hoger scoren op de C.C.F.N.I. (Molter, 1979) dan mannen (Daniels et al., 1989, Leske, 1991, 1992). Leske (1991,1992), onderzocht in de Verenigde Staten, over een periode van 10 jaar, de behoeften van 905 familieleden. Daniels et al., (1989), tonen aan dat vrouwen op de totale C.C.F.N.I. (Molter, 1979) hoger scoren dan mannen. Leske (1991,1992), geeft de invloed van vijf (sociaal-) demografische factoren op vijf behoeftecategorieën aan in een meta-analyse waarin in een periode van 10 jaar 905 familieleden zijn geïnterviewd. Leske $(1991,1992)$ toont aan, dat oudere respondenten significant meer behoeften hebben aan toegankelijkheid dan jongere respondenten. Bij de andere behoeftecategorieën zijn, met betrekking tot leeftijd, geen verschillen gevonden. Ook met betrekking tot het geslacht van de respondenten is door Leske $(1991,1992)$ een significant verschil aangetoond met betrekking tot de behoeften aan toegankelijkheid. Vrouwen hebben meer behoeften aan toegankelijkheid dan mannen. Met betrekking tot de relatie van de respondenten met de patiënt hebben partners meer behoeften aan toegankelijkheid (Leske 1991, 1992). Respondenten die onbekend zijn met de intensive care hebben eveneens meer behoeften aan toegankelijkheid dan respondenten die bekend zijn met de intensive care.

Ook de opname-indicatie van de patiënt is in de studie van Leske $(1991,1992)$ van invloed op de behoeften aan toegankelijkheid. Familieleden van chirurgische patiënten op de intensive care hebben meer behoeften aan toegankelijkheid dan familieleden van patiënten met een andere opname-indicatie.

In deze studie is het geslacht van de familieleden van invloed op de behoeften aan toegankelijkheid op de intensive care. In tabel 6.4.1 is te zien dat zowel vrouwen in de totale onderzoeksgroep $(\mathrm{t}=-2.97 ; \mathrm{df}=201 ; \mathrm{p}=.00)$ als vrouwen in de groep familieleden van hartoperatiepatiënten $(t=-2.54 ; d f=97 ; p=.00)$ een hogere score (3.5) op de behoeftecategorie "toegankelijkheid" hebben dan mannen (3.3). In de totale onderzoeksgroep hebben de mannen een gemiddelde score op de behoeften aan toegankelijkheid van 3.3 ten opzichte van een gemiddelde score van de vrouwen van 3.5 . 
Ook in de groep familieleden van hart-operatiepatiënten is een duidelijk verschil gevonden. Hier scoren de mannen eveneens 3.3 en de vrouwen 3.5 gemiddeld op behoeften aan toegankelijkheid. In de groep familieleden van overige intensive care patiënten is dit verschil niet aangetoond.

Tabel 6.4.1 Invloed van geslacht op de behoeften van familieleden aan toegankelijkheid (\%)

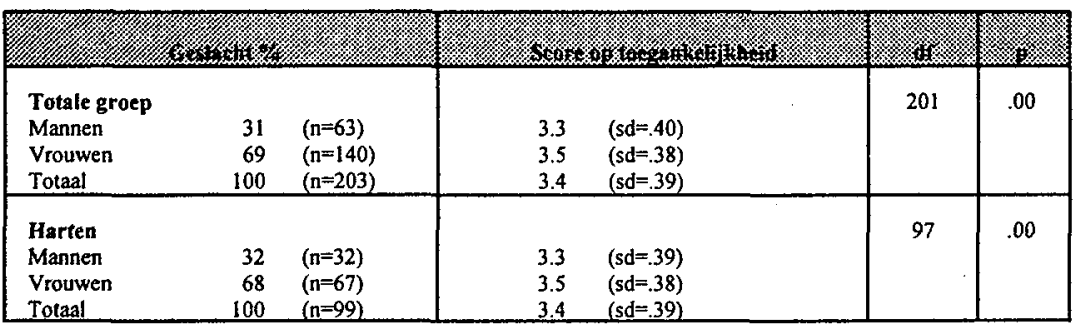

Min. score $=1$

Max. score $=4$

De relatie die het familielid heeft met de patiënt op de intensive care speelt, in de totale onderzoeksgroep, een beînvloedende rol (tabel 6.4.1.1). In de afzonderlijke groepen, familieleden van hartoperatiepatiënten en overige intensive care patiënten, speelt de relatie van het familielid met de patiënt geen duidelijke rol.

Tabel 6.4.1.1 Invloed van relatie op de behoeften van familieleden aan toegankelijkheid (\%)

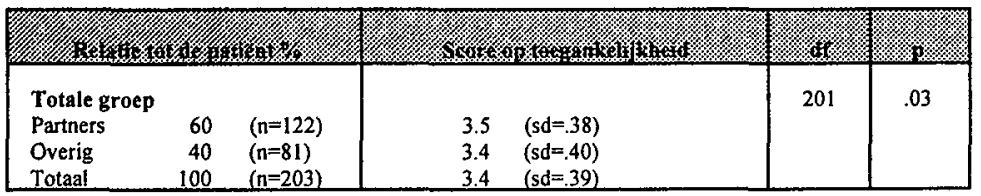

Min. score $=1$

Max. score $=4$

In tabel 6.4.1.1 is te zien dat partners van familieleden uit de totale onderzoeksgroep $(t=2.09$; $\mathrm{df}=201 ; \mathrm{p}=.03$ ) een hogere score (3.5) hebben op de behoeften aan toegankelijkheid dan andere familieleden (3.4) van intensive care patiënten. Partners vinden toegankelijkheid op de intensive care belangrijker dan andere familieleden.

Het feit of de familie bekend is met de intensive care is vooral van invloed in de groep familieleden van hartoperatiepatiënten $(t=2.02 ; \mathrm{df}=97 ; \mathrm{p}=.04)$. Tabel 6.4.1.2 laat zien dat familieleden die bekend zijn met de intensive care een hogere score hebben op de behoefte aan toegankelijkheid (3.5) dan familieleden die niet met de intensive care bekend zijn (3.4). In de totale onderzoeksgroep en in de groep familieleden van overige intensive care patiënten is dit verschil niet gevonden. 
Invloed van bekendheid met de intensive care op de behoeften van familieleden aan toegankelijkheid (\%)

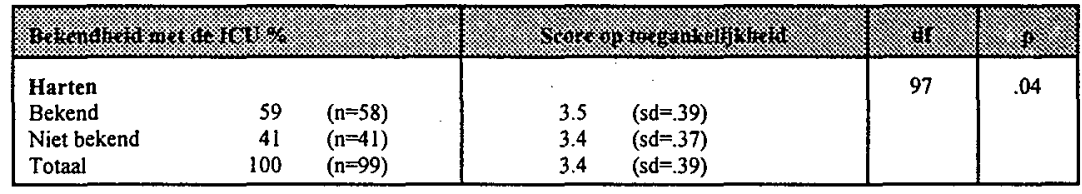

Min. score $=1$

Max.score $=4$

\subsubsection{Invloed van intensive care gelieerde factoren op behoeften aan toegankelijkheid}

Uitstel van de opname op de intensive care heeft invloed op de behoeften van familieleden aan toegankelijkheid op de intensive care (tabel 6.4.2).

Tabel 6.4.2 Invloed van uitstel van de opname op de behoeften van familieleden aan toegankelijkheid (\%)

\begin{tabular}{|c|c|c|c|c|c|c|}
\hline \multicolumn{3}{|c|}{ 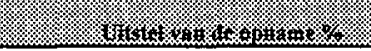 } & \multicolumn{2}{|c|}{ 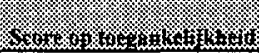 } & 统站 & 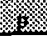 \\
\hline $\begin{array}{l}\text { Totale groep } \\
\text { Uitgesteld } \\
\text { Niet uitgesteld } \\
\text { Totaal }\end{array}$ & $\begin{array}{r}10 \\
90 \\
100 \\
\end{array}$ & $\begin{array}{l}(n=21) \\
(n=180) \\
(n=201)\end{array}$ & $\begin{array}{l}3.7 \\
3.4 \\
3.5 \\
\end{array}$ & $\begin{array}{l}(s d=.39) \\
(s d=.33) \\
(s d=.40)\end{array}$ & 199 & .00 \\
\hline $\begin{array}{l}\text { Harten } \\
\text { Uitgesteld } \\
\text { Niet uitgesteld } \\
\text { Totaal }\end{array}$ & $\begin{array}{r}14 \\
86 \\
100\end{array}$ & $\begin{array}{l}(n=14) \\
(n=83) \\
(n=97)\end{array}$ & $\begin{array}{l}3.7 \\
3.4 \\
3.5\end{array}$ & $\begin{array}{l}(s d=.39) \\
(s d=.34) \\
(s d=.40)\end{array}$ & 95 & .01 \\
\hline
\end{tabular}

Min. score $=1$

Max. score $=4$

Tabel 6.4.2 toont de invloed van uitstel van de opname van de patiënt op de intensive care in de totale onderzoeksgroep $(\mathrm{t}=-3.06 ; \mathrm{df}=199 ; \mathrm{p}=.00)$ en in de groep familieleden van hartoperatiepatiënten $(t=-.259 ; \mathrm{df}=95 ; \mathrm{p}=.01)$.

Familieleden van patiënten waarbij de opname op de intensive care is uitgesteld hebben een hogere score op de behoeften aan toegankelijkheid dan familieleden van patiënten waarbij de opname niet uitgesteld is. In de totale onderzoeksgroep is dit 3.7 ten opzichte van 3.4, in de groep familieleden van hartoperatiepatiënten is dit eveneens 3.7 ten opzichte van 3.4 . In de groep familieleden van overige intensive care patiënten is geen verschil aangetoond.

Opvallend is dat een onplezierige ervaring tevens van invloed is op de behoeften van familieleden aan toegankelijkheid. Wanneer deze variabele nader wordt beschouwd blijkt dat met name een onplezierige ervaring op het gebied van organisatie-gebonden factoren (wachttijd op opname , organisatie van de intensive care zoals bezoektijden) het meest frequent voorkomt. 
Een onplezierige ervaring op de intensive care beïnvloedt de behoeften aan toegankelijkheid. In alle onderzoeksgroepen is een duidelijke invloed te zien (tabel 6.4.2.1). Zowel familieleden in de totale onderzoeksgroep $(\mathrm{t}=5.72 ; \mathrm{df}=201 ; \mathrm{p}=.00)$ als in de groep familieleden van overige intensive care patiënten $(t=4.10 ; d f=102 ; p=.00)$ en in de groep familieleden van hartoperatiepatiënten $(t=3.94 ; \mathrm{df}=97 ; \mathrm{p}=.00)$ hebben familieleden met een onplezierige ervaring op de intensive care een hogere score (3.6) op behoeften aan toegankelijkheid dan familieleden die geen onplezierige ervaring (3.3) hebben meegemaakt.

Tabel 6.4.2.1 Invloed van een onplezierige ervaring op de behoeften van familieleden aan toegankelijkheid (\%)

\begin{tabular}{|c|c|c|c|c|c|c|}
\hline \multicolumn{3}{|c|}{ 1 } & \multicolumn{2}{|c|}{ 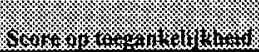 } & (a) & 被 \\
\hline $\begin{array}{l}\text { Onplezierige ervaring } \\
\text { Geen onplezierige ervaring } \\
\text { Totaal }\end{array}$ & $\begin{array}{r}56 \\
44 \\
100 \\
\end{array}$ & $\begin{array}{l}(n=113) \\
(n=90) \\
(n=203)\end{array}$ & $\begin{array}{l}3.6 \\
3.3 \\
3.5 \\
\end{array}$ & $\begin{array}{l}(\mathrm{sd}=.35) \\
(\mathrm{sd}=.38) \\
(\mathrm{sd}=.39)\end{array}$ & & \\
\hline $\begin{array}{l}\text { Overigen } \\
\text { Onplezierige ervaring } \\
\text { Geen onplezierige ervaring } \\
\text { Totaal }\end{array}$ & $\begin{array}{r}55 \\
45 \\
100 \\
\end{array}$ & $\begin{array}{l}(n=57) \\
(n=47) \\
(n=104) \\
\end{array}$ & $\begin{array}{l}3.6 \\
3.3 \\
3.5 \\
\end{array}$ & $\begin{array}{l}(s d=36) \\
(s d=38) \\
(s d=.40) \\
\end{array}$ & 102 & .00 \\
\hline $\begin{array}{l}\text { Harten } \\
\text { Onplezierige ervaring } \\
\text { Geen onplezierige ervaring } \\
\text { Totaal }\end{array}$ & $\begin{array}{r}57 \\
43 \\
100\end{array}$ & $\begin{array}{l}(n=56) \\
(n=43) \\
(n=99)\end{array}$ & $\begin{array}{l}3.6 \\
3.3 \\
3.5\end{array}$ & $\begin{array}{l}(\mathrm{sd}=.35) \\
(\mathrm{sd}=.38) \\
(\mathrm{sd}=.39)\end{array}$ & 97 & .00 \\
\hline
\end{tabular}

Min. score $=1$

Max. score $=4$

\subsubsection{Invloed van ziektegebonden factoren op behoeften aan toegankelijkheid}

De opnamefrequentie van de patiënt (het feit dat de patiënt eerder opgenomen is geweest op de intensive care) heeft invloed op de behoeften van familieleden aan toegankelijkheid. Opvallend is hier dat familieleden van patiënten die eerder opgenomen zijn geweest een hogere score hebben op behoeften aan toegankelijkheid dan familieleden van patiënten die voor de eerste keer zijn opgenomen.

Tabel 6.4.3 Invloed van opnamefrequentie op de behoeften van familieleden aan toegankelijkheid (\%)

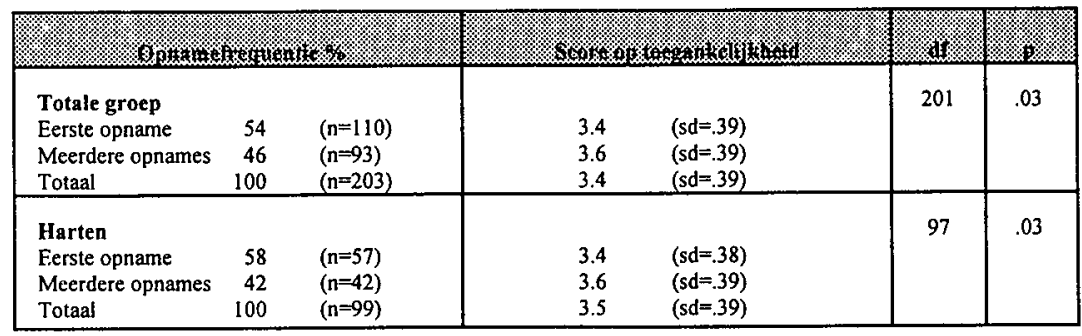

Min. score $=1$

Max. score $=4$ 
In tabel 6.4.3 is te zien dat in de totale onderzoeksgroep de score familieleden van patiënten die eerder opgenomen zijn geweest een score van 3.6 ten opzichte van 3.4 bij familieleden van patiënten die niet eerder opgenomen zijn geweest $(t=-2.19 ; d f=201 ; p=.03)$. In de groep familieleden van hartoperatiepatiënten is de score van familieleden van patiënten die eerder opgenomen zijn geweest 3.6 ten opzichte van 3.4 bij familieleden van patiënten die voor de eerste keer op de intensive care zijn opgenomen ( $t=-2.21$; $f=97 ; p=.03)$.

\subsubsection{Invloed van copingfactoren op behoeften aan toegankelijkheid}

Opvallend is dat geen van de vier copingstijlen invloed heeft op de behoeften van familieleden aan toegankelijkheid. De veronderstelling dat (hoofdstuk 2, tabel 2.5.2.1) de copingstijlen "actief aanpakken" en vermoedelijk ook "sociale steun zoeken" een positief effect vertonen op behoeften aan toegankelijkheid kan dan ook niet worden gehandhaafd. Ook het veronderstelde negatieve effect van de copingstijl "afwachten en vermijden" kan niet worden aangetoond.

Mogelijk ligt hier een verklaring in het feit dat familieleden geneigd zijn zichzelf weg te cijferen (Daley, 1984), terwijl tegelijkertijd de behoefte aan structuur bestaat. Met name de behoeftecategorie "behoeften aan toegankelijkheid" bestaat uit variabelen die toegeschreven kunnen worden aan regels en structuur (iedere dag met dezelfde verpleegkundige kunnen spreken, bezoekuren die op tijd beginnen, etc.). Waarschijnlijk leggen familieleden zich neer bij bestaande regels. Ook wanneer onduidelijkheid bestaat ten aanzien van deze regels, is het waarschijnlijk zo dat familieleden zichzelf wegcijferen.

\subsubsection{Samenvatting}

Behoeften van familieleden aan toegankelijkheid worden, in de totale onderzoeksgroep, in de eerste plaats beïnvloed door het geslacht van het familielid en de relatie die deze heeft met de patiënt. Vrouwen en partners hebben meer behoeften aan toegankelijkheid dan mannen en overige familieleden. Het feit of de opname van de patiënt uitgesteld is geweest leidt tot een grotere behoefte aan toegankelijkheid. Een onplezierige ervaring op de intensive care heeft eveneens toename van behoeften aan toegankelijkheid tot gevolg. Familieleden van patiënten die eerder opgenomen zijn geweest hebben duidelijk meer behoeften aan toegankelijkheid dan familieleden van patiënten die voor de eerste keer zijn opgenomen op de intensive care. Copinggedrag heeft geen invloed op behoeften aan toegankelijkheid.

In de groep familieleden van hartoperatiepatiënten hebben vrouwen meer behoeften aan toegankelijkheid dan mannen. Familieleden die bekend zijn met de intensive care hebben meer behoeften aan toegankelijkheid dan familieleden die onbekend zijn.

Uitstel van de opname leidt, evenals een onplezierige ervaring, tot toename van behoeften aan toegankelijkheid. Familieleden van patiënten die eerder opgenomen zijn geweest hebben duidelijk meer behoeften aan toegankelijkheid dan familieleden van patiënten die voor de eerste keer zijn opgenomen op de intensive care. Copinggedrag heeft geen invloed op behoeften aan toegankelijkheid. 
In de groep familieleden van overige intensive care patiënten is alleen een onplezierige ervaring van invloed op behoeften aan toegankelijkheid. Familieleden met een onplezierige ervaring op de intensive care hebben duidelijk meer behoeften aan toegankelijkheid dan familieleden die geen onplezierige ervaring hebben meegemaakt.

\subsection{Behoeften van familieleden aan begeleiding}

Behoeften aan begeleiding kenmerkt zich in deze studie als het totaal van de behoeftecategorieën "informatie", "ondersteuning" en "toegankelijkheid" en is als zodanig opgebouwd uit de 18 behoefte-items die de totale behoeftelijst vormen. Omdat in geen van de eerdere studies een dergelijke algemene behoeftecategorie is beschreven worden geen literatuurverwijzingen, gericht op behoeften in het algemeen, gegeven.

\subsubsection{Invloed van sociaal-demografische factoren op behoeften aan begeleiding}

Zoals uit tabel 6.5.1 valt af te lezen is het geslacht van het familielid van invloed op diens behoeften aan begeleiding. Zowel in de totale onderzoeksgroep $(\mathrm{t}=-3.43 ; \mathrm{df}=198 ; \mathrm{p}=.00)$ als in de groep familieleden van hartoperatiepatiënten $(t=-3.25 ; \mathrm{df}=95 ; \mathrm{p}=.00)$ hebben vrouwen (gemiddelde score van 3.0) duidelijk meer behoeften aan begeleiding dan mannen (gemiddelde score van 2.8).

Tabel 6.5.1 Invloed van geslacht op de behoeften van familieleden aan begeleiding (\%)

\begin{tabular}{|c|c|c|c|c|c|c|}
\hline \multicolumn{3}{|c|}{ 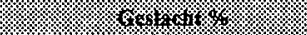 } & \multicolumn{2}{|c|}{ (50) } & (1) & 3) \\
\hline $\begin{array}{l}\text { Totale groep } \\
\text { Mannen } \\
\text { Vrouwen } \\
\text { Totaal }\end{array}$ & $\begin{array}{r}31 \\
69 \\
100\end{array}$ & $\begin{array}{l}(\mathrm{n}=62) \\
(\mathrm{n}=138) \\
(\mathrm{n}=200)\end{array}$ & $\begin{array}{l}2.8 \\
3.0 \\
2.9\end{array}$ & $\begin{array}{l}(\mathrm{sd}=.32) \\
(\mathrm{sd}=.35) \\
(\mathrm{sd}=.35)\end{array}$ & 198 & .00 \\
\hline $\begin{array}{l}\text { Harten } \\
\text { Mannen } \\
\text { Vrouwen } \\
\text { Totaal }\end{array}$ & $\begin{array}{r}32 \\
68 \\
100\end{array}$ & $\begin{array}{l}(n=31) \\
(n=66) \\
(n=97)\end{array}$ & $\begin{array}{l}2.8 \\
3.0 \\
2.9\end{array}$ & $\begin{array}{l}(\mathrm{sd}=.31) \\
(\mathrm{sd}=.34) \\
(\mathrm{sd}=35)\end{array}$ & 95 & .00 \\
\hline
\end{tabular}

Min score $=1$

Max. score $=4$

Het feit dat familieleden gelovig zijn is van invloed op behoeften aan begeleiding in de totale onderzoeksgroep en in de groep familieleden van overige intensive care patiënten.

In tabel 6.5.1.1 is te zien dat familieleden die gelovig zijn, een hogere score $(t=2.32 ; \mathrm{df}=198$; $\mathrm{p}=.02)$ voor de totale groep en $(\mathrm{t}=2.37 ; \mathrm{df}=101 ; \mathrm{p}=.02)$ voor de groep familieleden van overige intensive care patiënten) op begeleiding hebben (3.0) dan familieleden die niet gelovig zijn (2.8). Ook hier dient wederom te worden opgemerkt dat het afzonderlijke behoefte-item "behoefte aan een pastoraal medewerker" de resultaten beïnvloedt. 
Tabel 6.5.1.1 Invloed van geloof op de behoeften van familieleden aan begeleiding (\%)

\begin{tabular}{|c|c|c|c|c|c|c|}
\hline \multicolumn{3}{|c|}{$6 \%$} & \multicolumn{2}{|c|}{ 3.6.5. } & 14 & 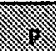 \\
\hline $\begin{array}{l}\text { Totale groep } \\
\text { Gelovig } \\
\text { Niet gelovig } \\
\text { Totaal }\end{array}$ & $\begin{array}{r}70 \\
30 \\
100\end{array}$ & $\begin{array}{l}(n=139) \\
(n=61) \\
(n=200)\end{array}$ & $\begin{array}{l}3.0 \\
2.8 \\
2.9\end{array}$ & $\begin{array}{l}(s d=34) \\
(s d=.34) \\
(s d=.35)\end{array}$ & 198 & .02 \\
\hline $\begin{array}{l}\text { Overigen } \\
\text { Gelovig } \\
\text { Niet gelovig } \\
\text { Totaal }\end{array}$ & $\begin{array}{r}66 \\
33 \\
100\end{array}$ & $\begin{array}{l}(n=68) \\
(n=35) \\
(n=103)\end{array}$ & $\begin{array}{l}3.0 \\
2.8 \\
2.8\end{array}$ & $\begin{array}{l}(s d=.33) \\
(s d=.35) \\
(s d=.35)\end{array}$ & 101 & .02 \\
\hline
\end{tabular}

Min. score $=1$

Max. score $=4$

\subsubsection{Invloed van intensive care gelieerde factoren op behoeften aan begeleiding}

Een onplezierige ervaring op de intensive care is, in alle onderzoeksgroepen, van invloed op behoeften aan begeleiding. In tabel 6.5.2 is te zien dat zowel familieleden in de totale onderzoeksgroep $(\mathrm{t}=2.30 ; \mathrm{df}=198 ; \mathrm{p}=.00)$ als in de groep familieleden van hartoperatiepatiënten $(t=2.71 ; d f=95 ; p=.00)$ en in de groep familieleden van overige intensive care patiënten $(t=2.65 ; d f=101 ; p=.00)$, die een onplezierige ervaring hebben meegemaakt op de intensive care, een duidelijk hogere score hebben op begeleiding ( 3.0 in alle groepen) dan familieleden die geen onplezierige ervaring hebben meegemaakt ( 2.8 in alle groepen). Ook hier domineert een onplezierige ervaring op het gebied van organisatorische aspecten (wachttijd op opname, organisatie van de intensive care zoals bezoektijden).

Tabel 6.5.2 Invloed van een onplezierige ervaring op de behoeften van familieleden aan begeleiding (\%)

\begin{tabular}{|c|c|c|c|c|c|c|}
\hline \multicolumn{3}{|c|}{ 1017 } & \multicolumn{2}{|c|}{ Кำ. } & \% & \% \\
\hline $\begin{array}{l}\text { Totale groep } \\
\text { Onplezierige ervaring } \\
\text { Geen onplezierige ervaring } \\
\text { Totaal }\end{array}$ & $\begin{array}{r}56 \\
44 \\
100\end{array}$ & $\begin{array}{l}(n=112) \\
(n=88) \\
(n=200)\end{array}$ & $\begin{array}{l}3.0 \\
2.8 \\
2.9\end{array}$ & $\begin{array}{l}(s d=.35) \\
(s d=.32) \\
(s d=.35)\end{array}$ & 198 & .00 \\
\hline $\begin{array}{l}\text { Harten } \\
\text { Onplezierige ervaring } \\
\text { Geen onplezierige ervaring } \\
\text { Totaal }\end{array}$ & $\begin{array}{r}58 \\
42 \\
100\end{array}$ & $\begin{array}{l}(n=56) \\
(n=41) \\
(n=97)\end{array}$ & $\begin{array}{l}3.0 \\
2.8 \\
2.9\end{array}$ & $\begin{array}{l}(s d=.36) \\
(s d=.30) \\
(s d=.35)\end{array}$ & 95 & .00 \\
\hline $\begin{array}{l}\text { Overigen } \\
\text { Onplezierige ervaring } \\
\text { Geen onplezierige ervaring } \\
\text { Totaal }\end{array}$ & $\begin{array}{r}54 \\
46 \\
100\end{array}$ & $\begin{array}{l}(n=56) \\
(n=47) \\
(n=103)\end{array}$ & $\begin{array}{l}3.0 \\
2.8 \\
2.9\end{array}$ & $\begin{array}{l}(\mathrm{sd}=34) \\
(\mathrm{sd}=34) \\
(\mathrm{sd}=.35)\end{array}$ & 101 & .00 \\
\hline
\end{tabular}

Min. score $=1$

Max. score $=4$ 


\subsubsection{Invloed van ziektegebonden factoren op behoeften aan begeleiding}

Mechanische beademing van de patiënt is van invloed op de behoeften aan begeleiding in de totale onderzoeksgroep $(t=2.20 ; d f=198 ; p=.03)$ en in de groep familieleden van overige intensive care patiënten $(t=2.08 ; \mathrm{df}=101 ; \mathrm{p}=.04)$. In tabel 6.5 .3 is te zien dat familieleden van patiënten die mechanische beademd worden een hogere score op begeleiding hebben dan familieleden van patiënten die niet mechanische beademd worden.

In de totale onderzoeksgroep is dit 3.0 ten opzichte van 2.8 en de groep familieleden van overige intensive care patiënten is dit eveneens 3.0 ten opzichte van 2.8 .

Tabel 6.5.3 Invloed van mechanische beademing op de behoeften van familieleden an begeleiding (\%)

\begin{tabular}{|c|c|c|c|c|c|c|}
\hline \multicolumn{3}{|c|}{ Kk, } & \multicolumn{2}{|c|}{ 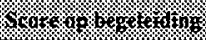 } & 哜 & $\sqrt{16}$ \\
\hline $\begin{array}{l}\text { Totale groep } \\
\text { Beademd } \\
\text { Niet beademd } \\
\text { Totaal }\end{array}$ & $\begin{array}{r}36 \\
64 \\
100\end{array}$ & $\begin{array}{l}(n=73) \\
(n=127) \\
(n=200)\end{array}$ & $\begin{array}{l}3.0 \\
2.8 \\
2.9\end{array}$ & $\begin{array}{l}(s d=.33) \\
(s d=.35) \\
(s d=.35)\end{array}$ & 198 & .03 \\
\hline $\begin{array}{l}\text { Overigen } \\
\text { Beademd } \\
\text { Niet beademd } \\
\text { Totaal }\end{array}$ & $\begin{array}{r}49 \\
51 \\
100\end{array}$ & $\begin{array}{l}(n=50) \\
(n=53) \\
(n=103)\end{array}$ & $\begin{array}{l}3.0 \\
2.8 \\
2.9\end{array}$ & $\begin{array}{l}(s d=35) \\
(s d=.34) \\
(s d=35)\end{array}$ & 101 & .04 \\
\hline
\end{tabular}

Min. score $=1$

Max. score $=4$

De opnamefrequentie van de patiënt is van invloed in de totale onderzoeksgroep $(t=-3.24$; $\mathrm{df}=198 ; \mathrm{p}=.00)$ en in de groep familieleden van hartoperatiepatiënten $(\mathrm{t}=-2.71 ; \mathrm{df}=95 ; \mathrm{p}=.00)$. In tabel 6.5.3.1 is te zien dat familieleden van patiënten die eerder opgenomen zijn geweest op de intensive care een hogere score hebben op behoeften aan begeleiding ( 3.0 in beide groepen) dan familieleden van patiënten die voor de eerste keer zijn opgenomen ( 2.8 in beide groepen).

Tabel 6.5.3.1 Invloed van opnamefrequentie op de behoeften van familieleden aan begeleiding (\%)

\begin{tabular}{|c|c|c|c|c|c|c|}
\hline \multicolumn{3}{|c|}{ 1 } & \multicolumn{2}{|c|}{ 45x次 } & 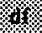 & \% \\
\hline $\begin{array}{l}\text { Totale groep } \\
\text { Eerste opname } \\
\text { Meerdere opnames } \\
\text { Totaal }\end{array}$ & $\begin{array}{r}54 \\
46 \\
100\end{array}$ & $\begin{array}{l}(n=108) \\
(n=92) \\
(n=200)\end{array}$ & $\begin{array}{l}2.8 \\
3.0 \\
2.9\end{array}$ & $\begin{array}{l}(s d=.34) \\
(s d=.34) \\
(s d=.35)\end{array}$ & 198 & .00 \\
\hline $\begin{array}{l}\text { Harten } \\
\text { Eerste opname } \\
\text { Meerdere opnames } \\
\text { Totaal }\end{array}$ & $\begin{array}{r}58 \\
42 \\
100\end{array}$ & $\begin{array}{l}(n=56) \\
(n=41) \\
(n=97)\end{array}$ & $\begin{array}{l}2.8 \\
3.0 \\
2.9\end{array}$ & $\begin{array}{l}(s d=.33) \\
(s d=.35) \\
(s d=.35)\end{array}$ & 95 & .00 \\
\hline
\end{tabular}

Min score $=1$

Max. score $=4$ 


\subsubsection{Invloed van copingstijlen op behoeften aan begeleiding}

Alleen de copingstijlen "sociale steun zoeken" en "palliatief gedrag" zijn van invloed op behoeften aan begeleiding. "Sociale steun zoeken" is van invloed in de totale onderzoeksgroep en in de groep familieleden van overige intensive care patiënten (tabel 6.5.4) en "palliatief gedrag" beïnvloedt de behoeften aan begeleiding in de totale onderzoeksgroep en in de groep familieleden van hartoperatiepatiënten (tabel 6.5.4.1).

Omdat de algemene behoeftecategorie "behoeften aan begeleiding", zoals ook in hoofdstuk 2 is beschreven, het totaal weergeeft van de drie behoeftecategorieën, is het verklaarbaar dat copinggedrag van familieleden eveneens invloed heeft op behoeften aan begeleiding. Voor deze categorie is dit zowel verondersteld effectief als verondersteld ineffectief gedrag. Beide copingstijlen leiden tot toename van behoeften aan begeleiding, waarbij opgemerkt dient te worden dat familieleden met geprefereerd steun zoekend gedrag waarschijnlijk duidelijker zijn in het kenbaar maken van behoeften dan familieleden met geprefereerd "palliatief gedrag". Met name de laatste groep zal meer aandacht vragen van de intensive care medewerkers.

In tabel 6.5.4 is te zien dat, in totale onderzoeksgroep, familieleden met een relatief hoge score op "sociale steun zoeken" (groter of gelijk aan de gemiddelde score) duidelijk hoger $(\mathrm{t}=3.17 ; \mathrm{df}=198 ; \mathrm{p}=.00)$ scoren op behoeften aan begeleiding (3.0) dan familieleden met een relatief lage score (lager dan het gemiddelde) op "sociale steun zoeken" (score van 2.8 op behoeften aan begeleiding). In de groep familieleden van overige intensive care patiënten zijn dezelfde resultaten gevonden $(\mathrm{t}=3.15 ; \mathrm{df}=101 ; \mathrm{p}=.00)$. Hier zijn de scores op behoeften aan begeleiding eveneens 3.0 ten opzichte van 2.8 .

Tabel 6.5.4 Invloed van "sociale steun zoeken" op behoeften van familieleden aan begeleiding (\%)

\begin{tabular}{|c|c|c|c|c|c|c|}
\hline \multicolumn{3}{|c|}{ Why } & \multicolumn{2}{|c|}{ 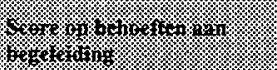 } & in & \% \\
\hline $\begin{array}{l}\text { Totale groep } \\
\text { Meanscore } \\
\text { 2 meanscore } \\
\text { < meanscore } \\
\text { Totaal }\end{array}$ & $\begin{array}{r}49 \\
51 \\
100\end{array}$ & $\begin{array}{l}(2.3, s d=.60) \\
(n=99) \\
(n=101) \\
(n=200)\end{array}$ & $\begin{array}{l}3.0 \\
2.8 \\
2.9\end{array}$ & $\begin{array}{l}(s d=.32) \\
(s d=.35) \\
(s d=.35)\end{array}$ & 198 & .00 \\
\hline $\begin{array}{l}\text { Overigen } \\
\text { Meanscore } \\
\geq \text { meanscore } \\
\text { < meanscore } \\
\text { Totaal }\end{array}$ & $\begin{array}{r}56 \\
44 \\
100\end{array}$ & $\begin{array}{l}(2.5, s d=.60) \\
(n=58) \\
(n=45) \\
(n=103)\end{array}$ & $\begin{array}{l}3.0 \\
2.8 \\
2.9\end{array}$ & $\begin{array}{l}(\mathrm{sd}=.34) \\
(\mathrm{sd}=.32) \\
(\mathrm{sd}=.35)\end{array}$ & 101 & .00 \\
\hline
\end{tabular}

Min. score $=1$

Max. score $=4$

Tabel 6.5.4.1 toont de resultaten met betrekking tot "palliatief gedrag". Hier is te zien dat familieleden in de totale onderzoeksgroep met een relatief hoge score op "palliatief gedrag" een $(t=2.23 ; d f=198 ; p=.02)$ hogere score op behoeften aan begeleiding hebben (3.0) dan familieleden met een lage score op palliatief gedrag (score van 2.8 op behoeften aan begeleiding). 
Deze resultaten komen overeen met de resultaten in de groep familieleden van hartoperatiepatiënten ( $t=2.69 ; \mathrm{df}=95 ; \mathrm{p}=.00)$. Hier scoren familieleden met een hoge score op "palliatief gedrag" 3.0 op begeleiding ten opzichte van 2.8 bij familieleden met een lage score op "palliatief gedrag".

Tabel 6.5.4.1 Invloed van "palliatief gedrag" op behoeften van familieleden aan begeleiding (\%)

\begin{tabular}{|c|c|c|c|c|c|c|}
\hline \multicolumn{3}{|c|}{ (1) } & \multicolumn{2}{|c|}{ 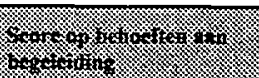 } & \multirow{2}{*}{$\begin{array}{l}. \\
198\end{array}$} & \multirow{2}{*}{. } \\
\hline $\begin{array}{l}\text { Totale groep } \\
\text { Meanscore } \\
\text { z meanscore } \\
\text { < meanscore } \\
\text { Totaal }\end{array}$ & $\begin{array}{r}51 \\
49 \\
100\end{array}$ & $\begin{array}{l}(2.2, s d=.63) \\
(n=103) \\
(n=97) \\
(n=200)\end{array}$ & $\begin{array}{l}3.0 \\
2.8 \\
2.9\end{array}$ & $\begin{array}{l}(s d=34) \\
(s d=.35) \\
(s d=.35)\end{array}$ & & \\
\hline $\begin{array}{l}\text { Harten } \\
\text { Meanscore } \\
\text { z meanscore } \\
\text { < meanscore } \\
\text { Totaal }\end{array}$ & $\begin{array}{r}51 \\
49 \\
100\end{array}$ & $\begin{array}{l}(2.3, s d=.62) \\
(n=50) \\
(n=47) \\
(n=97)\end{array}$ & $\begin{array}{l}3.0 \\
2.8 \\
2.9\end{array}$ & $\begin{array}{l}(s d=.33) \\
(s d=.35) \\
(s d=.35)\end{array}$ & 95 & .00 \\
\hline
\end{tabular}

Min. score $=1$

Max. score $=4$

\subsubsection{Samenvatting}

Behoeften van familieleden aan begeleiding worden, in de totale onderzoeksgroep, beïnvloed door het geslacht en het geloof van de familieleden. Vrouwen hebben meer behoeften aan begeleiding dan mannen, familieleden die een geloof belijden hebben eveneens meer behoeften aan begeleiding. Een onplezierige en/of indrukwekkende ervaring op de intensive care heeft een toename van behoeften aan begeleiding tot gevolg. Familieleden van patiënten die mechanisch beademd worden hebben meer behoeften aan begeleiding dan familieleden van patiënten die zelfstandig ademen. Meerdere opnames van de patiënt op de intensive care leidt bij familieleden tot een toename van behoeften aan begeleiding. De copingstijlen "palliatief gedrag" en "sociale steun zoeken" leiden eveneens tot toename van behoeften aan begeleiding.

In de groep familieleden van hartoperatiepatiënten hebben vrouwen meer behoeften aan begeleiding dan mannen. Meerdere opnames van de patiënt op de intensive care heeft eveneens toename van behoeften aan begeleiding tot gevolg.

De copingstijl "palliatief gedrag" heeft een positieve invloed op behoeften aan begeleiding.

In de groep familieleden van overige intensive care patiënten speelt het geloof van familieleden een rol. Familieleden die een geloof belijden hebben meer behoeften aan begeleiding dan familieleden die geen geloof belijden. Mechanische beademing van de patiënt leidt tot toename van behoeften aan begeleiding. De copingstijl "sociale steun zoeken" heeft eveneens een toename van behoeften aan begeleiding tot gevolg. 


\subsection{Kenmerken van familieleden en invloed op behoeften}

In de volgende paragrafen worden, met behulp van aspectmetingen met de beïnvloedende variabelen, voorspellingen gedaan voor specifieke doelgroepen familieleden gericht op de behoeftecategorieën ("informatie", "ondersteuning", "toegankelijkheid" en "begeleiding").

Ondanks het gegeven dat het hier slechts een globale benadering van de onafhankelijke variabelen betreft en er geen dominante positie is toe te schrijven aan de op zich zelfstaande variabelen in de regressie, zijn uit theoretische en praktische overwegingen profielen ontwikkeld voor de behoeftecategorieën.

\subsubsection{Behoeften aan informatie}

Uit tabel 6.6 .1 is af te leiden dat 6 van de 8 beïnvloedende variabelen zijn opgenomen in de regressie analyse $\left(\chi^{2}=37.5 ; \mathrm{df}=6 ; \mathrm{p}=.00\right)$, namelijk (1) leeftijd, (2) geslacht, (3) wachttijd op opname, (4) een onplezierige ervaring, (5) opnamefrequentie en (6) de copingstijl "sociale steun zoeken". Deze 6 kenmerken kunnen gezien worden als de 6 beste voorspellers voor behoeften van familieleden aan informatie.

Tabel 6.6.1 Logistische regressie analyse voor de variabele "behoeften aan informatie" ( $n=201)$

\begin{tabular}{|c|c|c|c|c|c|}
\hline 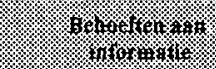 & 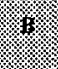 & 8 & 8 & . & 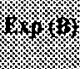 \\
\hline $\begin{array}{l}\text { Geslacht } \\
\text { Leeftijd } \\
\text { Wachttijd } \\
\text { Onplezierige ervaring } \\
\text { Opnamefrequentie } \\
\text { Sociale steun zoeken } \\
\text { Constant }\end{array}$ & $\begin{array}{r}-.63 \\
.95 \\
-.71 \\
.67 \\
-.89 \\
.72 \\
. .24\end{array}$ & $\begin{array}{l}.35 \\
.35 \\
.32 \\
.32 \\
.32 \\
.31 \\
.41\end{array}$ & $\begin{array}{l}.07 \\
.00 \\
.03 \\
.04 \\
.00 \\
.02 \\
.55\end{array}$ & $\begin{array}{r}-.06 \\
.14 \\
-.10 \\
.09 \\
-.14 \\
.11\end{array}$ & $\begin{array}{r}.53 \\
2.56 \\
.49 \\
.96 \\
.40 \\
2.06\end{array}$ \\
\hline
\end{tabular}

$\chi^{2}=37.5, \mathrm{df}=6, \mathrm{p}=.00$

In tabel 6.6.1.1 is te zien dat, van de familieleden (100) met bovengenoemde kenmerken, $66 \%$ met indicatie informatie (groter of gelijk aan de gemiddelde score op informatie) en $69 \%$ (101) zonder indicatie informatie (kleiner dan de gemiddelde score op informatie) correct voorspeld kunnen worden door het model van de 6 genoemde variabelen. Van alle 201 familieleden wordt 68\% (137 familieleden) in de juiste groep ingedeeld.

Tabel 6.6.1.1 Verwachte score op behoeften aan informatie (classificatie voor informatie)

\begin{tabular}{|c|c|c|c|c|}
\hline \multicolumn{2}{|c|}{ 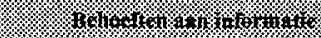 } & (x) & 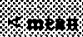 & \% \\
\hline 2 mean & $(n=100)$ & 66 & 34 & $66 \%$ \\
\hline$<$ mean & $(n=101)$ & 31 & 70 & $69 \%$ \\
\hline Totaal & $(n=201)$ & & & $68 \%$ \\
\hline
\end{tabular}


Wanneer het aantal correct voorspelde familieleden nader beschouwd wordt, is het mogelijk een (familie)profiel samen te stellen waarvan voorspeld kan worden dat in $66 \%$ de indicatie "behoeften aan informatie" gerechtvaardigd is. Uitgaande van de 6 in het model genoemde variabelen ontstaat het hier onder genoemde profiel (profiel I(nformatie).

\section{Het familielid is een vrouw}

2. Het familielid is jonger dan 60 jaar

3. Er is geen sprake geweest van wachttijd op opname van de patiënt

4. Het familielid heeft een onplezierige ervaring opgedaan

5. De patiënt is eerder opgenomen geweest op de intensive care

6. Het familielid heeft een hoge score op de copingstijl "sociale steun" zoeken

\subsubsection{Behoeften aan ondersteuning}

Uit tabel 6.6 .2 blijkt dat 4 van de 8 beïnvloedende variabelen zijn opgenomen $(\chi 2=17.92$; $\mathrm{df}=4 ; \mathrm{p}=.00$ ) in de regressie analyse, te weten: (1) geslacht, (2) religie en (3 en 4$)$ de copingstijlen "actief aanpakken" en "sociale steun zoeken". Deze kenmerken kunnen gezien worden als de 4 beste voorspellers voor behoeften van familieleden aan ondersteuning.

Tabel 6.6.2 Logistische regressie analyse voor de variabele "behoeften aan ondersteuning" ( $n=202)$

\begin{tabular}{|c|c|c|c|c|c|}
\hline 12) & 巣 & 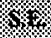 & 8 & 8 & (8) \\
\hline Geslacht & -.61 & .32 & .05 & -.07 & .54 \\
\hline Religie & .70 & .32 & .03 & .10 & 2.02 \\
\hline Actief aanpakken & -.68 & .31 & .03 & -.10 & .50 \\
\hline Sociale steun zoeken & .59 & .30 & .04 & .08 & 1.81 \\
\hline Constant & -.14 & .34 & .68 & & \\
\hline
\end{tabular}

$\left.\chi^{2}=17.92 ; \mathrm{df}=4 ; \mathrm{p}=.00\right)$

In tabel 6.6.2.1 is te zien dat, van de familieleden (115) met bovengenoemde kenmerken $88 \%$ met indicatie ondersteuning (groter of gelijk aan de gemiddelde score) en $36 \%$ (87 familieleden) zonder indicatie ondersteuning (kleiner dan de gemiddelde score) correct voorspeld kunnen worden door het model van de 4 genoemde variabelen. Van alle 202 familieleden wordt $64 \%$ (202 familieleden) in de juiste groep ingedeeld.

Tabel 6.6.2.1 Verwachte score op behoeften aan ondersteuning (classificatie voor behoeften aan ondersteuning)

\begin{tabular}{|c|c|c|c|c|}
\hline \multicolumn{2}{|c|}{ 3. } & \% & 18 & \% \\
\hline$\geq$ mean & $(n=115)$ & 101 & 14 & $88 \%$ \\
\hline$<$ mean & $(n=87)$ & 56 & 31 & $36 \%$ \\
\hline Totaal & $(n=202)$ & & & $64 \%$ \\
\hline
\end{tabular}


Wanneer het aantal correct voorspelde familieleden nader beschouwd wordt, is het mogelijk een (familie)profiel samen te stellen waarvan voorspeld kan worden dat in $88 \%$ de indicatie "behoeften aan ondersteuning" gerechtvaardigd is. Uitgaande van de 4 in het model genoemde variabelen ontstaat het hier onder genoemde profiel (profiel S(teun)).

\section{Het familielid is een vrouw \\ 2. Het familielid is gelovig \\ 3. Het familielid heeft een hoge score op de copingstijl "sociale steun zoeken" \\ 4. Het familielid heeft een lage score op de copingstijl "actief aanpakken"}

\subsubsection{Behoeften aan toegankelijkheid}

Tabel 6.6.3 toont dat 4 van de 6 beïnvloedende variabelen in de regressie analyse zijn opgenomen $(\chi 2=42.09 ; \mathrm{df}=4 ; \mathrm{p}=.00)$, te weten: (1) geslacht, (2) relatie, (3) uitstel van de opname en (4) een onplezierige ervaring. Deze 4 kenmerken kunnen gezien worden als de 4 beste voorspellers voor behoeften van familieleden aan toegankelijkheid.

Tabel 6.6.3 Logistische regressie analyse voor de variabele "behoeften aan toegankelijkheid".

\begin{tabular}{|c|c|c|c|c|c|}
\hline 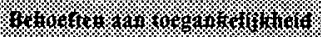 & 独 & \% & 新 & \% & (6) \\
\hline Geslacht & -.78 & .35 & .03 & -.10 & .46 \\
\hline Relatie & .67 & .33 & .04 & .08 & 1.96 \\
\hline Uitstel van de opname & 1.13 & .60 & .05 & .07 & 3.11 \\
\hline Onplezierige ervaring & 1.47 & 32 & .00 & .26 & 4.34 \\
\hline Constant & -1.69 & .67 & .01 & & \\
\hline
\end{tabular}

$\chi 2=42.09 ; \mathrm{df}=4 ; \mathrm{p}=.00$

In tabel 6.6.3.1 is te zien dat, van de familieleden met bovengenoemde kenmerken $69 \%$ (113 familieleden) met indicatie toegankelijkheid (groter of gelijk aan de gemiddelde score) en $70 \%$ ( 88 familieleden) zonder indicatie toegankelijkheid (kleiner dan de gemiddelde score) correct voorspeld kunnen worden door het model van de 4 genoemde variabelen. Van alle familieleden (201) wordt $70 \%$ in de juiste groep ingedeeld.

Tabel 6.6.3.1 Verwachte score op behoeften aan toegankelijkheid (classificatie voor behoeften aan toegankelijkheid)

\begin{tabular}{|c|c|c|c|c|}
\hline \multicolumn{2}{|c|}{ 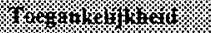 } & (x) & \% & \% \\
\hline 2 mean & $(n=113)$ & 78 & 35 & $69 \%$ \\
\hline$<$ mean & $(n=88)$ & 26 & 62 & $70 \%$ \\
\hline Totaal & $(n=201)$ & & & $70 \%$ \\
\hline
\end{tabular}


Wanneer het aantal correct voorspelde familieleden nader beschouwd wordt, is het mogelijk een (familie)profiel samen te stellen waarvan voorspeld kan worden dat in $69 \%$ de indicatie "behoeften aan toegankelijkheid" gerechtvaardigd is. Uitgaande van de 4 in het model genoemde variabelen ontstaat het hier onder genoemde profiel (profiel T(oegang).

\section{Het familielid is een vrouw}

2 Het familielid is de partner van de patiënt

3 De opname van de patiënt is uitgesteld

4 Het familielid heeft een onplezierige ervaring opgedaan

\subsubsection{Behoeften aan begeleiding}

Uit tabel 6.6 .4 blijkt dat 4 van de 7 beïnvloedende variabelen opgenomen zijn $\left(\chi^{2}=29.4\right.$; $\mathrm{p}=.00 ; \mathrm{df}-4$ ) in de regressie analyse, te weten: (1) geslacht, (2) een onplezierige ervaring, (3) opnamefrequentie en (4) de copingstijl "sociale steun zoeken". Deze kenmerken kunnen gezien worden als de 4 beste voorspellers voor behoeften van familieleden aan begeleiding.

Tabel 6.6.4 Logistische regressie analyse voor de variabele "behoeften aan begeleiding" ( $\mathrm{n}=206$ )

\begin{tabular}{|c|c|c|c|c|c|}
\hline 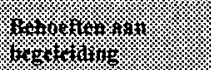 & 䇥 & K. & $\%$ & 3 & K \\
\hline $\begin{array}{l}\text { Geslacht } \\
\text { Onplezierige ervaring } \\
\text { Opnamefrequentie } \\
\text { Sociale steun zoeken } \\
\text { Constant }\end{array}$ & $\begin{array}{r}-.79 \\
.96 \\
-.55 \\
.56 \\
-.08\end{array}$ & $\begin{array}{l}.32 \\
.30 \\
.30 \\
.30 \\
.37\end{array}$ & $\begin{array}{l}.01 \\
.00 \\
.06 \\
.06 \\
.82\end{array}$ & $\begin{array}{r}-.11 \\
.16 \\
. .06 \\
.07\end{array}$ & $\begin{array}{c}.45 \\
2.62 \\
.57 \\
1.76\end{array}$ \\
\hline
\end{tabular}

$\chi^{2}=29.4 ; p=.00 ; \mathrm{df}=4$

In tabel 6.6.4.1 is te zien dat, van de familieleden met bovengenoemde kenmerken $72 \%$ (111 familieleden) met indicatie begeleiding en 61\% (95 familieleden) zonder indicatie behoeften aan begeleiding correct voorspeld kunnen worden door het model van de 4 genoemde variabelen. Van alle familieleden (206) wordt $67 \%$ in de juiste groep ingedeeld.

Tabel 6.6.4.1 Verwachte score op "behoeften aan begeleiding" (classificatie voor begeleiding)

\begin{tabular}{|c|c|c|c|c|}
\hline \multicolumn{2}{|c|}{ 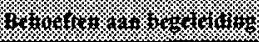 } & , 10 & 镃 & $x$ \\
\hline 2 mean & $(n=111)$ & 80 & 31 & $72 \%$ \\
\hline$<$ mean & $(\mathrm{n}=95)$ & 37 & 58 & $61 \%$ \\
\hline Totaal & $(n=206)$ & & & $67 \%$ \\
\hline
\end{tabular}


Wanneer het aantal correct voorspelde familieleden nader beschouwd wordt, is het mogelijk een (familie)profiel samen te stellen waarvan voorspeld kan worden dat in $72 \%$ de indicatie "behoeften aan begeleiding" gerechtvaardigd is. Uitgaande van de 4 in het model genoemde variabelen ontstaat het hier onder genoemde profiel.

\section{Het familielid is een yrouw}

2. Het familielid heeft een onplezierige ervaring opgedaan

3. De patiënt is eerder opgenomen geweest op de intensive care

4. Het familielid heeft een hoge score op de copingstijl "sociale steun zoeken"

Opvallend is dat in de regressie analyses de variabele geslacht van familieleden in alle behoeftecategorieën ("informatie", "ondersteuning", "toegankelijkheid" en "begeleiding") een rol speelt. Om te kijken of een specifieke benadering van vrouwelijke familieleden ten opzichte van mannelijke familieleden praktisch relevant is voor behoeften op de intensive care, zijn de analyses nogmaals uitgevoerd voor vrouwen en mannen afzonderlijk. Deze worden in de volgende paragrafen achtereenvolgens per behoeftecategorie eerst voor de vrouwelijke- en vervolgens voor de mannelijke familieleden gepresenteerd.

\subsubsection{Behoeften aan informatie voor mannen en vrouwen afzonderlijk}

\section{Vrouwen}

Wanneer de regressie wordt uitgevoerd voor vrouwen worden 4 van de 7 beïnvloedende variabelen opgenomen $\left(\chi^{2}=18.1 ; d f=4 ; p=.00\right)$ in het model, te weten: (1) leeftijd, (2) wachttijd op opname, (3) opnamefrequentie en (4) de copingstijl "sociale steun zoeken". Deze kenmerken kunnen gezien worden als de 4 beste voorspellers voor behoeften van vrouwelijke familieleden aan informatie.

Tabel 6.6.5 Logistische regressie analyse voor de variabele "behoeften aan informatie" voor vrouwen $(n=138)$.

\begin{tabular}{|c|c|c|c|c|c|}
\hline 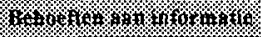 & 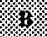 & 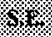 & 噇 & \% & 6 \\
\hline $\begin{array}{l}\text { Leefiijd } \\
\text { Wachttijd } \\
\text { Opnamefrequentie } \\
\text { Sociale steun zoeken } \\
\text { Constant }\end{array}$ & $\begin{array}{r}.90 \\
-.61 \\
-.97 \\
.79 \\
-.14\end{array}$ & $\begin{array}{l}.40 \\
.37 \\
.38 \\
.37 \\
.33\end{array}$ & $\begin{array}{l}.02 \\
.10 \\
.01 \\
.03 \\
.65\end{array}$ & $\begin{array}{r}.12 \\
-.05 \\
-.15 \\
.11\end{array}$ & $\begin{array}{r}2.47 \\
.54 \\
.38 \\
2.22\end{array}$ \\
\hline
\end{tabular}

$\chi^{2}=18.1 ; d f=4 ; p=.00$

Wanneer het model nader wordt beschouwd is het mogelijk om een vrouwelijk (familie)profiel samen te stellen waarbij de indicatie "behoeften aan informatie" geindiceerd is. Uitgaande van de 4 in het model genoemde variabelen ontstaat het hier onder genoemde profiel.

$1 \quad$ Het familielid is jonger dan 60 jaar

2 Er is geen sprake van wachttijd op opname

3 De patiënt is eerder opgenomen geweest op de intensive care

4 Het familielid heeft een relatief hoge score op de copingstijl "sociale steun zoeken" 


\section{Mannen}

Wanneer de regressie wordt uitgevoerd voor mannelijke familieleden blijkt dat (tabel 6.6.5.1) slechts 2 van de 7 beïnvloedende variabelen worden opgenomen $\left(\chi^{2}=6.77 ; \mathrm{df}=2 ; \mathrm{p}=.03\right)$ in de regressie, te weten: (1) wachttijd op opname van de patiënt en (2) een onplezierige ervaring. Deze kenmerken kunnen gezien worden als de 2 beste voorspellers voor behoeften van mannelijke familieleden aan informatie.

Tabel 6.6.5.1 Logistische regressie analyse voor de variabele "behoeften aan informatie" voor mannen $(n=63)$

\begin{tabular}{|c|c|c|c|c|c|}
\hline 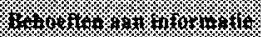 & $\%$ & \% & $\$$ & X) & $3 x$ \\
\hline $\begin{array}{l}\text { Wachttijd } \\
\text { Onplezierige ervaring } \\
\text { Constant }\end{array}$ & $\begin{array}{r}-1.04 \\
1.13 \\
.50\end{array}$ & $\begin{array}{l}.57 \\
.57 \\
.45\end{array}$ & $\begin{array}{l}.06 \\
.04 \\
.26\end{array}$ & $\begin{array}{r}-.12 \\
.15\end{array}$ & $\begin{array}{c}.35 \\
3.12\end{array}$ \\
\hline
\end{tabular}

$\chi^{2}=6.77 ; d e=2 ; p=.03$

Wanneer het model nader wordt beschouwd is het mogelijk om een mannelijk (familie)profiel samen te stellen waarbij de indicatie "behoeften aan informatie" geïndiceerd is.

Uitgaande van de 2 in het model genoemde variabelen ontstaat het hier onder genoemde profiel. Hieruit kan een profiel worden afgeleid dat voldoet aan twee kenmerken, te weten:

\section{$1 \quad$ Er is geen sprake van wachttijd op opname}

2 Het familielid heeft een onplezierige ervaring opgedaan

\subsubsection{Behoeften aan ondersteuning voor mannen en vrouwen afzonderlijk}

\section{Vrouwen}

Uit tabel 6.6 .6 valt af te leiden dat slechts 1 van de 7 beïnvloedende variabelen wordt opgenomen in het model $\left(\chi^{2}=3.01 ; \mathrm{df}=1 ; \mathrm{p}=.08\right)$, te weten: geloof. Dit kenmerk kan gezien worden als de beste voorspeller voor behoeften van vrouwelijke familieleden aan ondersteuning.

Tabel 6.6.6 Logistische regressie analyse voor de variabele "behoeften aan ondersteuning" voor vrouwen $(n=138)$

\begin{tabular}{|c|c|c|c|c|c|}
\hline 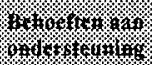 & $x$ & 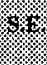 & \% & k & 4 \\
\hline $\begin{array}{l}\text { Religie } \\
\text { Constant }\end{array}$ & $\begin{array}{r}.65 \\
-.70\end{array}$ & $\begin{array}{l}.38 \\
.21\end{array}$ & $\begin{array}{l}.08 \\
.00\end{array}$ & .07 & 1.93 \\
\hline
\end{tabular}

$\chi^{2}=3.01 ; d f=1 ; p=.08$ 


\section{Mannen}

Bij de analyse voor mannelijke familieleden (tabel 6.6.6.1) wordt eveneens slechts 1 van de 7 beïnloedende variabelen opgenomen in de regressie $\left(\chi^{2}=5.79 ; \mathrm{df}=1 ; \mathrm{p}=.02\right)$, te weten: de copingstijl "actief aanpakken". Dit kenmerk kan gezien worden als de beste voorspeller voor behoeften van mannelijke familieleden aan ondersteuning.

Tabel 6.6.6.1 Logistische regressie analyse voor de variabele "behoeften aan ondersteuning" voor mannen $(\mathrm{n}=64)$

\begin{tabular}{|c|c|c|c|c|c|}
\hline 斿 & ma & x.x. & 1. & x. & $(8,(x, 8)$ \\
\hline $\begin{array}{l}\text { Actief aanpakken } \\
\text { Constant }\end{array}$ & $\begin{array}{r}-1.28 \\
.65\end{array}$ & $\begin{array}{l}.54 \\
.33\end{array}$ & $\begin{array}{l}.02 \\
.05\end{array}$ & -.19 & .28 \\
\hline
\end{tabular}

$\chi^{2}=5.79 ; d f=1 ; p=.02$

Hieruit kan geconcludeerd worden dat, wanneer het gaat om behoeften van familieleden aan ondersteuning het verschil tussen mannen en vrouwen met name te vinden is in de kenmerken "geloof" voor vrouwen en "copinggedrag" voor mannen.

\subsubsection{Behoeften aan toegankelijkheid voor mannen en vrouwen afzonderlijk}

\section{Vrouwen}

Als de analyse wordt uitgevoerd voor vrouwelijke familieleden gecontroleerd voor behoeften aan toegankelijkheid blijkt dat 3 van de 5 beïnvloedende variabelen (tabel 6.6.7) worden opgenomen $\left(\chi^{2}=16.08 ; \mathrm{df}=3 ; \mathrm{p}=.00\right)$ in de regressie, te weten: (1) bekendheid met de intensive care, (2) uitstel van de opname en (3) het opdoen van een onplezierige ervaring. Deze kenmerken kunnen gezien worden als de 3 beste voorspellers van behoeften van vrouwelijke familieleden aan toegankelijkheid.

Tabel 6.6.7 Logistische regressie analyse voor de variabele "behoeften aan toegankelijkheid" voor vrouwen $(\mathrm{n}=139)$

\begin{tabular}{|c|c|c|c|c|c|}
\hline 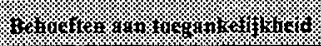 & 1 & 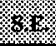 & Y & \& & 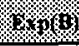 \\
\hline $\begin{array}{l}\text { Bekendheid met de intensive care } \\
\text { Uitstel van de opname } \\
\text { Onplezierige ervaring } \\
\text { Constant }\end{array}$ & $\begin{array}{r}.71 \\
1.48 \\
.93 \\
-2.62\end{array}$ & $\begin{array}{l}.38 \\
.79 \\
.38 \\
.80\end{array}$ & $\begin{array}{l}.06 \\
.06 \\
.01 \\
.00\end{array}$ & $\begin{array}{l}.09 \\
.09 \\
.14\end{array}$ & $\begin{array}{l}2.05 \\
4.4 \\
2.0\end{array}$ \\
\hline
\end{tabular}

$\chi^{2}=16.08 ; \mathrm{df}=3 ; \mathrm{p}=.00$

Wanneer het model nader wordt beschouwd is het mogelijk om een vrouwelijk (familie)profiel samen te stellen waarbij de indicatie "behoeften aan toegankelijkheid" geïndiceerd is. Uitgaande van de in het model genoemde variabelen ontstaat het hieronder genoemde profiel.

1 Het familielid is bekend met de intensive care

2 De opname van de patiënt is uitgesteld geweest

3 Het familielid heeft een onplezierige ervaring opgedaan 


\section{Mannen}

Bij de analyse voor mannelijke familieleden blijkt dat slechts 1 van de 5 beïnvloedende variabelen opgenomen wordt (tabel 6.6.7.1) in het model, te weten: (1) een onplezierige ervaring $\left(\chi^{2}=17.32 ; d f=1 ; p=.00\right)$. Deze variabele kan gezien worden als de beste voorspeller voor behoeften van mannelijke familieleden aan toegankelijkheid.

Tabel 6.6.7.1 Logistische regressie analyse voor de variabele "behoeften aan toegankelijkheid" voor mannen $(n=62)$

\begin{tabular}{|c|c|c|c|c|c|}
\hline 6. & 袹 & 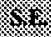 & 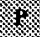 & 8 & \% \\
\hline $\begin{array}{l}\text { Onplezierige ervaring } \\
\text { Constant }\end{array}$ & $\begin{array}{l}2.64 \\
-.64\end{array}$ & $\begin{array}{l}.62 \\
.39\end{array}$ & $\begin{array}{l}.00 \\
.10\end{array}$ & .39 & 10.64 \\
\hline
\end{tabular}

$\chi^{2}=17.33 ; d f=1 ; p=.00$

Hieruit kan worden afgeleid dat behoeften aan toegankelijkheid bij mannelijke familieleden voorspeld kan worden door een onplezierige ervaring op de intensive care.

\subsubsection{Behoeften aan begeleiding voor mannen en vrouwen afzonderlijk}

\section{Vrouwen}

Uit tabel 6.6 .8 blijkt dat 2 van de 6 beïnvloedende variabelen, (1) een onplezierige ervaring en (2) opnamefrequentie van de patiënt opgenomen te worden in de regressie $\left(\chi^{2}=14.2\right.$; $\mathrm{p}=.00 ; \mathrm{df}=2)$. Deze variabelen kunnen gezien worden als de 2 beste voorspellers voor behoeften van vrouwelijke familieleden aan begeleiding.

Tabel 6.6.8 Logistische regressie analyse voor de variabele "behoeften aan begeleiding" voor vrouwen $(n=141)$

\begin{tabular}{|c|c|c|c|c|c|}
\hline 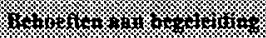 & 8 & 14 & x. & 8 & $4 \%$ \\
\hline $\begin{array}{l}\text { Onplezierige ervaring } \\
\text { Opnamefrequentie } \\
\text { Constant }\end{array}$ & $\begin{array}{l}1.16 \\
-.60 \\
-.67\end{array}$ & $\begin{array}{l}.36 \\
.36 \\
.30\end{array}$ & $\begin{array}{l}.00 \\
.09 \\
.02\end{array}$ & $\begin{array}{r}.20 \\
-.06\end{array}$ & $\begin{array}{l}3.21 \\
.54\end{array}$ \\
\hline
\end{tabular}

$x^{2}=14.2 ; p=.00 ; d f=2$

Wanneer het model nader wordt beschouwd is het mogelijk om een vrouwelijk (familie)profiel samen te stellen waarbij de indicatie "behoeften aan begeleiding" geïndiceerd is. Uitgaande van de in het model genoemde variabelen ontstaat het hieronder genoemde profiel.

\section{Het familielid heeft een onplezierige ervaring gehad}

2. De patiënt is eerder opgenomen geweest 


\section{Mannen}

Bij de analyse voor mannelijke familieleden wordt slechts 1 van de 5 beänvloedende variabelen, namelijk "sociale steun zoeken" opgenomen $\left(\chi^{2}=4.41 ; \mathrm{df}=1 ; \mathrm{p}=.04\right)$ in het model (tabel 6.6.8.1). Deze variabele kan gezien worden als de beste voorspeller voor behoeften van mannelijke familieleden aan begeleiding.

Tabel 6.6.8.1 Logistische regressie analyse voor de variabele "behoeften aan begeleiding" voor mannen $(n=65)$

\begin{tabular}{|c|c|c|c|c|c|}
\hline 6) & $\%$ & ( & 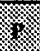 & 1 & . \\
\hline $\begin{array}{l}\text { Sociale steun zoeken } \\
\text { Constant }\end{array}$ & $\begin{array}{r}1.10 \\
-.07\end{array}$ & $\begin{array}{l}.53 \\
.38\end{array}$ & $\begin{array}{l}.04 \\
.84\end{array}$ & .16 & 3.01 \\
\hline
\end{tabular}

$X^{2}=4.41 ; d f=1 ; p=.04$

Hieruit kan worden afgeleid dat de behoeften van mannelijke familieleden aan ondersteuning op de intensive care met name voorspeld kan worden door het copinggedrag ("sociale steun zoeken") van mannen.

Met behulp van de, in dit hoofdstuk gevonden, kenmerken wordt het mogelijk voorspellingen te doen die gericht zijn op begeleiding van familieleden op de intensive care. Een duidelijk verschil is aangetoond tussen vrouwelijke- en mannelijke familieleden bij alle behoeftecategorieën. Duidelijk wordt dat de nadruk in bepaalde situaties op ondersteuning moet worden gelegd terwijl in andere situaties meer aandacht besteed moet worden aan toegankelijkheid. Wanneer de intensive care organisatie bewust gemaakt wordt van de verschillende achtergronden van familieleden en de daaruit voortvloeiende specifieke behoeften, kunnen voorwaarden geschapen worden waarbinnen verpleegkundigen in staat worden gesteld daadwerkelijk op behoeften van familieleden in te gaan.

Behoeften van familieleden krijgen op deze wijze een plaats in het verpleegkundig domein en worden, naast de patiënt, een specifiek aandachtsgebied voor de beroepsgroep.

\subsection{Samenvatting}

Behoeften van familieleden op de intensive care worden beïnvloed door verschillende onafhankelijke en overige factoren. Zowel in de totale onderzoeksgroep als in de beide afzonderlijke onderzoeksgroepen is invloed te zien. In totaal zijn 15 factoren van invloed, waarvan 5 sociaal-demografische factoren, 3 intensive care gelieerde factoren, 3 ziektegebonden factoren en 4 copingstijlen. De bevindingen uit dit hoofdstuk zijn weergegeven in figuur 6.7. 
Figuur 6.7 Invloed van onafhankelijke en overige factoren op behoeften van familieleden

\section{Beïnvloedende factoren}

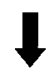

Sociaal-demografische factoren

Geslacht

Geloof

Leeftijd

Relatie

Bekendheid

Intensive care gelieerde factoren Onplezierige ervaring

Wachttijd

Uitstel

\section{Ziektegebonden factoren}

Beademing

Opnamefrequentie

Levensbedreiging

\section{Copingfactoren}

Sociale steun zoeken

Palliatief gedrag

Actief aanpakken

Afwachten en vermijden $\rightarrow \quad$ Behoeften

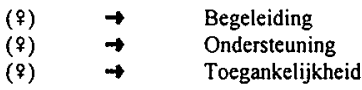

$(+) \rightarrow \quad$ Begeleiding

$(+) \rightarrow$ Ondersteuning

$(<6 \mathrm{ljr}) \rightarrow$ Informatic

(partner) $\rightarrow \quad$ Toegankelijkheid

$(+) \quad \rightarrow \quad$ Toegankelijkheid

$(+) \quad \rightarrow \quad$ Informatie

(+) $\rightarrow$ Toegankelijkheid

$(-) \quad \rightarrow \quad$ Informatie

$(+) \quad \rightarrow \quad$ Informatie

$(+) \quad \rightarrow \quad$ Toegankelijkheid

$(+) \quad \rightarrow \quad$ Ondersteuning

$(+) \rightarrow$ Begeleiding

$(+) \quad \rightarrow \quad$ Informatie

$(+) \quad \rightarrow \quad$ Toegankelijkheid

(hoog) $\rightarrow \quad$ Ondersteuning

(+) $\rightarrow \quad$ Begeleiding

$(+) \quad \rightarrow \quad$ Informatie

(+) $\rightarrow$ Ondersteuning

$(+) \quad \rightarrow \quad$ Begeleiding

$(+) \quad \rightarrow \quad$ Ondersteuning

(t) $\rightarrow \quad$ Informatie

$(-) \quad \rightarrow \quad$ Ondersteuning

$(+) \quad \rightarrow \quad$ Ondersteuning 
Vervolgens zijn verschillende profielen ontwikkeld voor de algemene en de afzonderlijke behoeftecategorieën (tabel 6.7.1).

Tabel 6.7.1 Overzicht profielen logistische regressie analyses

\begin{tabular}{|c|c|c|}
\hline 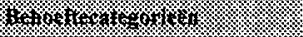 & \multicolumn{2}{|c|}{ 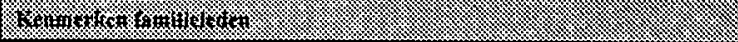 } \\
\hline Behoeften aan informatie & $\rightarrow$ & $\begin{array}{l}\text { Het familielid is een vrouw } \\
\text { Het familielid is jonger dan } 60 \text { jaar } \\
\text { Er bestond een wachttijd op opname } \\
\text { Het familielid heeft een onplezierige ervaring opgedaan } \\
\text { De patient is eerder opgenomen geweest } \\
\text { Het familielid heeft een hoge score op de copingstijl "sociale steun } \\
\text { zoeken" }\end{array}$ \\
\hline Behoeften aan ondersteuning & $\rightarrow$ & $\begin{array}{l}\text { Het familielid is een vrouw } \\
\text { Het familielid is gelovig } \\
\text { Het familielid heeft een hoge score op de copingstij] "sociale steun } \\
\text { zoeken" } \\
\text { Het familielid heeft een lage score op de copingstijl "actief } \\
\text { aanpakken" }\end{array}$ \\
\hline Behoeften aan toegankelijkheid & $\rightarrow$ & $\begin{array}{l}\text { Het familielid is een vrouw } \\
\text { Het familielid is de partner van de patient } \\
\text { De opname van de patient is uitgesteld geweest } \\
\text { Het familielid heeft een onplezierige ervaring opgedaan }\end{array}$ \\
\hline Behoeften aan begeleiding & $\rightarrow$ & $\begin{array}{l}\text { Het familielid is een vrouw } \\
\text { Het familielid heeft een onplezierige ervaring opgedaan } \\
\text { De patient is eerder opgenomen geweest } \\
\text { Het familielid heeft een hoge score op de copingstijl "sociale steun } \\
\text { zoeken" }\end{array}$ \\
\hline
\end{tabular}

Voor alle behoeftecategorieën is nogmaals een logistische regressie analyse uitgevoerd voor vrouwelijke en mannelijke respondenten afzonderlijk (tabel 6.7.2). Duidelijk wordt dat, met behulp van de ontwikkelde profielen, de zorg voor familieleden meer specifiek kan worden afgestemd op de behoeften van familieleden op de intensive care. Voor mannelijke familieleden speelt een onplezierige ervaring, de plotselinge opname van de patiënt en copinggedrag een rol bij behoeften op de intensive care. Voor vrouwelijke familieleden speelt leeftijd, wachttijd, bekendheid, uitstel van de opname, opnamefrequentie van de patiënt, een onplezierige ervaring en copinggedrag een rol. 
Tabel 6.7.2 Overzicht logistische regressie analyses voor mannelijke- en vrouwelijke familieleden.

\begin{tabular}{|l|l|l|}
\hline Behoeften aan informatie & $\begin{array}{l}\text { Jonger dan } 60 \text { jaar } \\
\text { Wachttijd op opname } \\
\text { Patient is eerder opgenomen geweest } \\
\text { Hanteert de copingstijl "sociale steun zoeken" } \\
\text { Behoeften aan ondersteuning }\end{array}$ & $\begin{array}{l}\text { Geen wachttijd op opname } \\
\text { Onplezierige ervaring }\end{array}$ \\
Gelovig & $\begin{array}{l}\text { Hanteert niet de copingstijl "actief } \\
\text { aanpakken" }\end{array}$ \\
Behoeften aan toegankelijkheid & $\begin{array}{l}\text { Bekend met de intensive care } \\
\text { Opname is uitgesteld geweest } \\
\text { Onplezierige ervaring } \\
\text { Onplezierige ervaring } \\
\text { Patient is eerder opgenomen geweest }\end{array}$ & $\begin{array}{l}\text { Onplezige ervaring } \\
\text { Hanteert de copingstijl "sociale steun } \\
\text { zoeken" }\end{array}$ \\
\hline
\end{tabular}

Met behulp van de resultaten van de regressie analyses die in dit hoofdstuk worden beschreven ontstaat de mogelijkheid om de invloed van onafhankelijke en overige factoren op behoeften van familieleden specifieker te presenteren. In figuur 6.7.3 is nogmaals te zien welke onafhankelijke- en overige factoren een rol spelen bij behoeften van familieleden, waarbij het geslacht van familieleden een belangrijke rol speelt. 
Figuur 6.7.3 Rol van onafhankelijke en overige factoren bij behoeften van familieleden

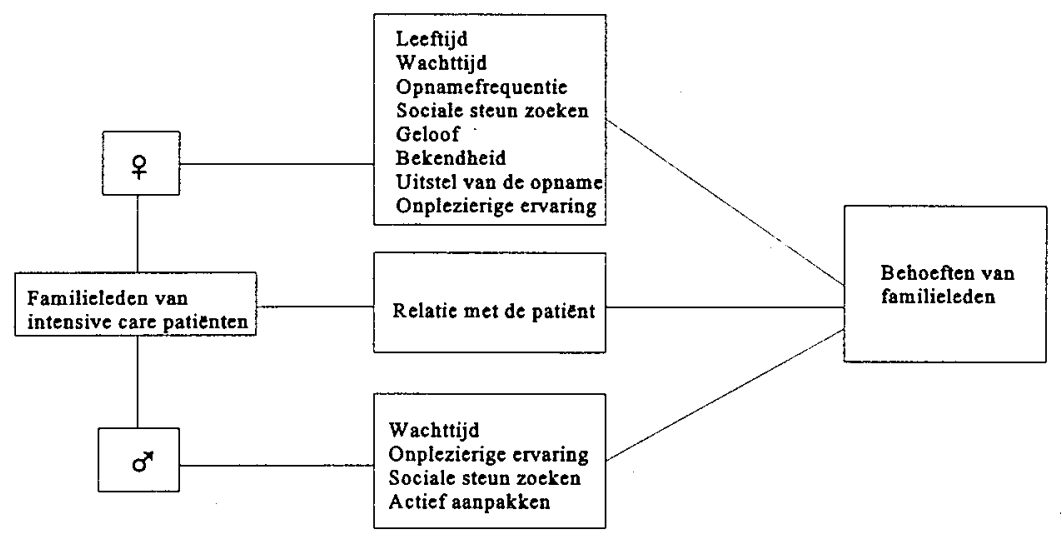




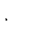




\section{TYPOLOGIE BINNEN DE BEHOEFTEN VAN FAMILIELEDEN}

\subsection{Inleiding}

In dit hoofdstuk worden de typen familieleden van intensive care patiënten op de intensive care gepresenteerd. De typologie is toegepast op behoefte-item niveau binnen de behoeftecategorieën. Alleen de behoefte-items die bestaan uit vier (sub)vragen, ( $(A)$ vindt u het belangrijk?, (B) door wie wilt u dat dit gedaan wordt?, (C) is het gedaan? en (D) door wie is het gedaan?) en als zodanig antwoord geven op de deelvraagstellingen, die zijn afgeleid van de eerste centrale onderzoeksvraag (hoofdstuk 3) worden in de typologie opgenomen (figuur 7.1). Op deze wijze is gepoogd respondenten te classificeren in typen familieleden waarbij de antwoorden op de subvragen binnen één behoefte-item de basis voor de typering vormt.

Figuur 7.1 Stroomschema typologie

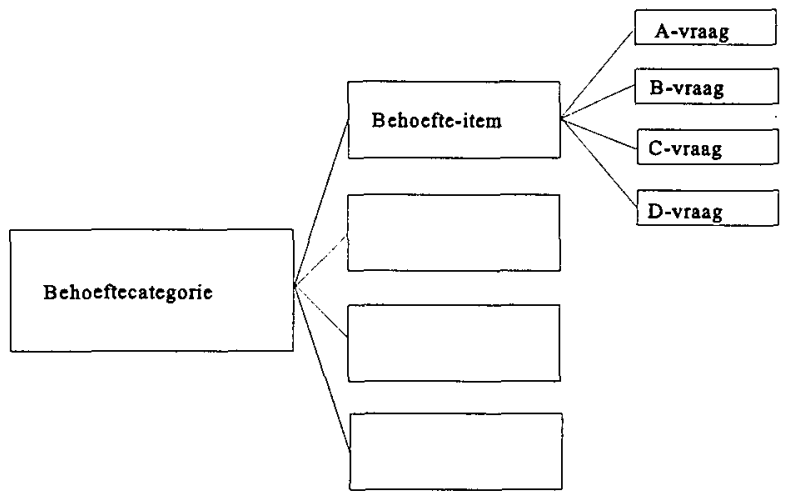

\footnotetext{
A-vraag meet de behoefte

$B$-vraag meet wie in de behoefte dient te voorzien

$C$-vraag meet of er in de behoefie is voorzien

$D$-vraag meet wie er in de behoefte heeft voorzien
}

Ten gevolge van bovengenoemde vier-deling van de behoefte-items is de behoeftecategorie "toegankelijkheid" buiten beschouwing gelaten omdat deze categorie uit behoefte-items met uitsluitend A-vragen bestaat (zie bijlage 9), zodat ieder behoefte-item door één vraag wordt gemeten. Vervolgens is het ook zo dat niet alle behoefte-items uit de categorieën informatie en ondersteuning uit vier (sub)vragen bestaan. 
Om bovenstaande redenen zijn uiteindelijk zeven behoefte-items, ieder uit vier (sub)vragen opgebouwd, in de typologie opgenomen, te weten:

1. Behoefte aan aanwezigheid van een intensive care medewerker tijdens het eerste bezoek aan de patiënt op de intensive care

\section{Behoefte aan ondersteuning van een intensive care medewerker}

\section{Behoefte om te kunnen spreken over ervaringen en gevoelens}

\section{Behoefte aan informatie over overplaatsing van de patiënt}

\section{Behoefte aan een contactpersoon op de intensive care}

\section{Behoefte aan uitleg over de werking van de apparatuur}

\section{Behoefte aan uitleg over de medische behandeling van de patiënt}

De typologie is congruent aan de vier antwoordschalen binnen de afzonderlijke behoefteitems. Zo worden bij ieder behoefte-item de meest voorkomende antwoorden, per vier (sub)vragen, beschreven en in frequent voorkomende typen geclassificeerd (tabel 7.1.1). Een aantal typen die relatief zelden tot weinig voorkomen zijn om die reden niet meegenomen in de typologie.

\subsubsection{Opbouw van de typologie}

Bij de opbouw van de typologie is in eerste instantie gekeken naar het belang van de behoefte (de A-vraag). Hier wordt een onderscheid gemaakt tussen belangrijk en niet belangrijk (een herclassificatie van de originele schaal, waarbij onbelangrijk en niet zo belangrijk geclassificeerd worden in niet belangrijk en belangrijk en zeer belangrijk geclassificeerd worden in belangrijk). Ook hier worden de beide onderzoeksgroepen (familieleden van hartoperatiepatiënten en familieleden van overige intensive care patiënten) afzonderlijk beschreven. In tweede instantie wordt de voorkeur voor de wenselijke behoefteverstrekker in kaart gebracht (de B-vraag), waarbij wederom de twee groepen familieleden worden onderscheiden. Tot slot zal, van beide onderzoeksgroepen, een overzicht getoond worden waarin te zien is of er daadwerkelijk in de behoefte is voorzien en door wie (de C-en D-vraag). In tabel 7.1.1 wordt een overzicht gepresenteerd van de meest voorkomende typen familieleden, gerelateerd aan de antwoordmogelijkheden per behoefte-item. 
Tabel 7.1.1 Meest voorkomende typen familieleden van intensive care patiënten

\begin{tabular}{|c|c|}
\hline $\begin{array}{l}\text { Type 1 } \\
\text { B.V.J.V. }\end{array}$ & $\begin{array}{l}\text { a. Familieleden vinden het belangrijk } \\
\text { b. Men vindt dat het door de yerpleegkundige gedaan moet worden } \\
\text { c. Ja, het is daadwerkelijk gedaan } \\
\text { d. Het is door de verpleegkundige gedaan }\end{array}$ \\
\hline $\begin{array}{l}\text { Type } 2 \\
\text { B.A.J.A. }\end{array}$ & $\begin{array}{l}\text { a. Familieleden vinden het belangrijk } \\
\text { b. Men vindt dat het door de grts gedaan moet worden } \\
\text { c. Ja, het is daadwerkelijk gedaan } \\
\text { d. Het is door de arts gedaan }\end{array}$ \\
\hline $\begin{array}{l}\text { Type } 3 \\
\text { B.A.J.V. }\end{array}$ & $\begin{array}{l}\text { a. Familieleden vinden het belangrijk } \\
\text { b. Men vindt dat het door de arts gedaan moet worden } \\
\text { c. Ja, het is daadwerkelijk gedaan } \\
\text { d. Het is door de verpleegkundige gedaan }\end{array}$ \\
\hline $\begin{array}{l}\text { Type } 4 \\
\text { B.G.J.G. }\end{array}$ & $\begin{array}{l}\text { a. Familieleden vinden het belangrijk } \\
\text { b. Men vindt dat het doot de gastvrouw gedaan moet worden } \\
\text { c. Ja, het is daadwerkelijk gedaan } \\
\text { d. Het is door de gastvrouw gedaan }\end{array}$ \\
\hline $\begin{array}{l}\text { Type } 5 \\
\text { B.V.J.G. }\end{array}$ & $\begin{array}{l}\text { a. Familieleden vinden het belangrijk } \\
\text { b. Men vindt dat het door de verpleegkundige gedaan moet worden } \\
\text { c. } \mathrm{J} \text { a, het is daadwerkelijk gedaan } \\
\text { d. Het is door de gastvrouw gedaan }\end{array}$ \\
\hline $\begin{array}{l}\text { Type } 6 \\
\text { B.V.N. }\end{array}$ & $\begin{array}{l}\text { a. Familieleden vinden het belangrijk } \\
\text { b. Men vindt dat het door de yerpleegkundige gedaan moet worden } \\
\text { c. Nee, het is niet gedaan }\end{array}$ \\
\hline $\begin{array}{c}\text { Type } 7 \\
\text { B.A.N. }\end{array}$ & $\begin{array}{l}\text { a. Familieleden vinden het belangrijk } \\
\text { b. Men vindt dat het door de grts gedaan moet worden } \\
\text { c. Nee, het is niet gedaan }\end{array}$ \\
\hline $\begin{array}{l}\text { Type } 8 \\
\text { NB. }\end{array}$ & a. Familieleden vinden het nַiet belangrijk \\
\hline
\end{tabular}

De acht meest voorkomende typen zijn vervolgens gereduceerd tot vier typen (tabel 7.1.2) familieleden, waarbij type 1, 2 en 3 de behoefte belangrijk vinden en type 4 de behoefte niet belangrijk vindt. Aan deze keuze ligt met name de praktische relevantie voor de beroepspraktijk ten grondslag, immers op deze wijze kunnen (verpleegkundige) interventies, gericht op behoeften van familieleden, op specifieke (familie-) doelgroepen afgestemd worden.

Tabel 7.1.2 Typering familieleden

\begin{tabular}{|c|c|}
\hline 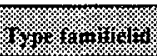 & x.7. \\
\hline Type 1 & $\begin{array}{l}\text { Vindt de behoefte belangrijk } \\
\text { Er is door de gewenste behoefteverstrekker in voorzien }\end{array}$ \\
\hline Type 2 & $\begin{array}{l}\text { Vindt de behoefte belangrijk } \\
\text { Er is door een andere discipline in voorzien }\end{array}$ \\
\hline Type 3 & $\begin{array}{l}\text { Vindt de behoefte belangrijk } \\
\text { Er is niet in de behoefte voorzien }\end{array}$ \\
\hline Type 4 & Vindt de behoefte niet belangrijk \\
\hline
\end{tabular}




\subsection{Belang van de behoeften}

In de behoeftecategorie "behoeften aan ondersteuning" komen drie behoefte-items voor die uit vier (sub)vragen bestaan, (1) de aanwezigheid van een intensive care medewerker bij het eerste bezoek op de intensive care, (2) ondersteuning door een intensive care medewerker en (3) het kunnen bespreken van ervaringen en gevoelens met een intensive care medewerker. In de behoeftecategorie "behoeften aan informatie" komen vier behoefte-items voor die uit vier (sub)vragen bestaan, (1) informatie over een eventuele overplaatsing van de patiënt, (2) de aanwezigheid van een contactpersoon op de intensive care, (3) informatie over de apparatuur die bij de patiēnt gebruikt wordt en (4) informatie over de medische behandeling van de patiënt. Tabel 7.2 toont een overzicht van de zeven behoefte-items die in de typologie zijn opgenomen. De familieleden die aangeven de behoefte belangrijk te vinden vormen de basis voor de eerste drie typen familieleden (type 1, 2 en 3, tabel 7.1.2). Type 4, het type dat de behoefte niet belangrijk vindt, wordt niet verder uitgewerkt in de typologie.

Tabel 7.2 Overzicht behoefte-items die in de typologie zijn opgenomen

\begin{tabular}{|c|c|c|c|}
\hline 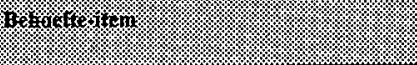 & \multicolumn{2}{|c|}{ 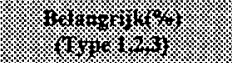 } & 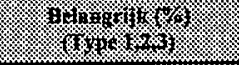 \\
\hline Behoefte aan: & (1) & 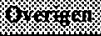 & Hownong \\
\hline $\begin{array}{l}\text { Uitleg over de medische behandeling } \\
(n=174)\end{array}$ & 86 & 87 & 86 \\
\hline $\begin{array}{l}\text { Aanwezigheid van een intensive care mede- } \\
\text { werker tijdens het eerste bezoek }(n=174)\end{array}$ & 83 & 79 & 81 \\
\hline $\begin{array}{l}\text { Aanwezigheid van een contactpersoon } \\
(n=181)\end{array}$ & 81 & 72 & 76 \\
\hline $\begin{array}{l}\text { Informatie over overplaatsing van de } \\
\text { patient* }(n=52)\end{array}$ & 83 & 50 & 69 \\
\hline $\begin{array}{l}\text { Ondersteuning van een intensive care mede- } \\
\text { werker }(n=169)\end{array}$ & 56 & 56 & 56 \\
\hline Uitleg over de apparatuur $(n=189)$ & 48 & 56 & 52 \\
\hline $\begin{array}{l}\text { Kunnen spreken over ervaringen en gevoe- } \\
\text { lens }(n=176)\end{array}$ & $2 \mathrm{I}$ & 25 & 23 \\
\hline
\end{tabular}

${ }^{*} p<.005$

Het meest belangrijk vinden familieleden de uitleg over de medische behandeling $(86 \%)$. Familieleden vinden de aanwezigheid van een intensive care medewerker tijdens het eerste bezoek op de intensive care eveneens belangrijk (81\%). Ook de aanwezigheid van een contactpersoon op de intensive care (76\%) en de informatie over een eventuele overplaatsing van de patiënt $(69 \%)$ vindt men belangrijk (alleen familieleden die daadwerkelijk met overplaatsing van de patiënt te maken hebben gehad ( 52 familieleden) zijn in de typologie opgenomen. Opvallend is dat hier een verschil bestaat tussen de beide onderzoeksgroepen. Familieleden van hartoperatiepatiënten vinden $\left(\chi^{2}=6.62, \mathrm{df}=1, \mathrm{p}=.01\right)$ deze informatie belangrijker $(83 \%)$ dan familieleden van overige intensive care patiënten $(50 \%)$. 
Ondersteuning door een intensive care medewerker op de intensive care vindt $56 \%$ van de familieleden belangrijk. Het kunnen spreken over ervaringen en gevoelens op de intensive care vindt slechts $23 \%$ belangrijk.

Tussen de beide groepen familieleden wordt, met uitzondering van de informatie over een eventuele overplaatsing van de patiënt, geen verschil gevonden met betrekking tot de in tabel 7.2 genoemde behoefte-items.

\subsection{Gewenste behoefteverstrekker}

In de tweede subvraag (de B-vraag) van de zeven, in de typologie opgenomen, behoefte-items is gevraagd naar de gewenste behoefteverstrekker. In tabel 7.3 wordt een overzicht gepresenteerd van de gewenste behoefteverstrekkers, waarbij een onderscheid wordt gemaakt tussen familieleden van hartoperatiepatiënten en familieleden van overige intensive care patiënten. Alleen de type 1-,2- en 3-familieleden zijn in de tabel opgenomen, de type 4-familieleden vinden de behoefte niet belangrijk en zijn om die reden uitgesloten van verdere uitwerking van de typologie.

Tabel 7.3 Overzicht gewenste behoefteverstrekkers (\%).

\begin{tabular}{|c|c|c|c|c|c|c|c|c|}
\hline \multirow{2}{*}{$\begin{array}{l}\text { mox } \\
\text { Behoefte aan: } \\
\text { Bex }\end{array}$} & \multicolumn{4}{|c|}{ 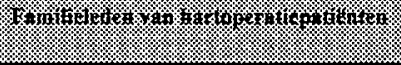 } & \multicolumn{4}{|c|}{ 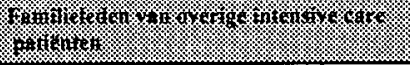 } \\
\hline & Verpl.k & Arts & Gastvrouw & Totaal & Verpl.k & Arts & Gastvrouw & Totaal \\
\hline $\begin{array}{l}\text { Uitleg over de medische behandeling } \\
(n=150)^{*}\end{array}$ & 62 & 38 & 0 & $\begin{array}{c}100 \\
(n=71)\end{array}$ & 39 & 61 & 0 & $\begin{array}{c}100 \\
(n=79)\end{array}$ \\
\hline $\begin{array}{l}\text { Aanwezigheid van een intensive care } \\
\text { medewerker tijdens het eerste bezoek } \\
(n=141)^{*}\end{array}$ & 61 & 20 & 19 & $\begin{array}{c}100 \\
(n=70)\end{array}$ & 76 & 3 & 21 & $\begin{array}{c}100 \\
(n=71)\end{array}$ \\
\hline $\begin{array}{l}\text { Aanwezigheid van een contactpersoon } \\
(n=138)\end{array}$ & 66 & 7 & 27 & $\begin{array}{c}100 \\
(n=70)\end{array}$ & 65 & 16 & 19 & $\begin{array}{c}100 \\
(\mathrm{n}=68)\end{array}$ \\
\hline $\begin{array}{l}\text { Informatie over overplaatsing van de } \\
\text { patient }(n=36)\end{array}$ & 100 & 0 & 0 & $\begin{array}{c}100 \\
(n=25)\end{array}$ & 100 & 0 & 0 & $\begin{array}{c}100 \\
(n=11)\end{array}$ \\
\hline $\begin{array}{l}\text { Ondersteuning van een intensive care } \\
\text { medewerker }(\mathrm{n}=95)\end{array}$ & 81 & 0 & 19 & $\begin{array}{c}100 \\
(n=41)\end{array}$ & 78 & 0 & 22 & $\begin{array}{c}100 \\
(n=54)\end{array}$ \\
\hline Uitleg over de apparatuur $(n=99)$ & 100 & 0 & 0 & $\begin{array}{c}100 \\
(n=42)\end{array}$ & 100 & 0 & 0 & $\begin{array}{c}100 \\
(\mathbf{n}=57)\end{array}$ \\
\hline $\begin{array}{l}\text { Kunnen spreken over ervaringen en } \\
\text { gevoelens }(n=41)\end{array}$ & 72 & 28 & 0 & $\begin{array}{c}100 \\
(n=18)\end{array}$ & 83 & 17 & 0 & $\begin{array}{c}100 \\
(n=23)\end{array}$ \\
\hline
\end{tabular}

$* p<.005$

In tabel 7.3 is te zien dat familieleden een duidelijke voorkeur hebben voor de verpleegkundige als het om behoeften op de intensive care gaat. 
Alleen bij de behoefte aan aanwezigheid van een intensive care medewerker tijdens het eerste bezoek aan de patiënt, behoefte aan ondersteuning op de intensive care en behoefte aan een contactpersoon, speelt de gastvrouw een (relatief kleine) rol. Opvallend is de wens voor de arts als het gaat om de aanwezigheid van een intensive care medewerker tijdens het eerste bezoek aan de patiënt.

Familieleden van hartoperatiepatiënten (20\%) kennen de arts hier een duidelijk grotere rol toe dan familieleden van overige intensive care patiënten $(3 \%)\left(\chi^{2}=10.38, \mathrm{df}=2, \mathrm{p}=.00\right)$. De voorkeur voor de verpleegkundige blijft echter in beide groepen bestaan.

Een tweede opvallend verschil tussen beide groepen familieleden is de behoefte aan uitleg over de medische behandeling van de patiënt. Waar familieleden van hartoperatiepatiënten een duidelijke voorkeur hebben voor de verpleegkundige $(62 \%)$, geven familieleden van overige intensive care patiënten (61\%) sterk de voorkeur aan de arts $\left(\chi^{2}=7.72, \mathrm{df}=1, \mathrm{p}=.00\right)$.

\subsection{De feitelijke gang van zaken}

In deze paragraaf wordt het antwoord gegeven op de vraag of de potentiële behoefteverstrekkers daadwerkelijk op de behoeften van familieleden zijn ingegaan (de C- en Dvraag). Naast het onderscheid tussen de twee groepen familieleden kunnen drie typen familieleden worden onderscheiden. Het eerste type (1) vindt de behoefte belangrijk en er is daadwerkelijk door de gewenste behoefteverstrekker in voorzien, het tweede type (2) vindt de behoefte belangrijk, er is daadwerkelijk in de behoefte voorzien, echter door een andere discipline en het derde type (3) vindt de behoefte belangrijk, echter er is niet in de behoefte voorzien.

In tabel 7.4 is te zien dat, wanneer daadwerkelijk in de behoeften van familieleden wordt voorzien, dit over het algemeen door de gewenste behoefteverstrekker wordt gedaan. Uitzondering vormt hier de behoefte aan aanwezigheid van een intensive care medewerker tijdens het eerste bezoek aan de patiënt. Hier is een duidelijk verschil te zien tussen de beide groepen familieleden $\left(\chi^{2}=7.48, \mathrm{df}=2, \mathrm{p}=.02\right)$. In de groep familieleden van hartoperatiepatiënten is in $33 \%$ van de gevallen wel iemand aanwezig geweest, echter het betrof hier niet de verpleegkundige. In de groep familieleden van overige intensive care patiënten is dit slechts $14 \%$. Wel is het $\mathrm{zo}$, dat in $11 \%$ van de gevallen niemand aanwezig was bij de groep familieleden van overige intensive care patiënten ten opzichte van $6 \%$ in de groep familieleden van hartoperatiepatiënten.

Een tweede verschil is te zien bij de behoefte aan uitleg over de medische behandeling. In de groep familieleden van hartoperatiepatiënten wordt in meer dan de helft van de gevallen $(51 \%)$ niet in deze behoefte voorzien, terwijl dit in de groep familieleden van overige intensive care patiënten wel het geval is $(68 \%)$. 


\begin{tabular}{|c|c|c|c|c|c|c|c|c|}
\hline \multirow[t]{2}{*}{ 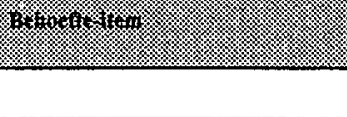 } & \multicolumn{4}{|c|}{ (3) } & \multicolumn{4}{|c|}{ ming } \\
\hline & Type I & Type 2 & Type 3 & & Type 1 & Type 2 & Type 3 & \\
\hline Behoefte aan: & $\mathrm{Ja} / \mathrm{Ja}$ & $\mathrm{Ja}$ anders & $\mathrm{Ja} / \mathrm{Nee}$ & Totaal & $\mathbf{J a} / \mathbf{J a}$ & Ja/anders & $\mathrm{Ja} / \mathrm{Nee}$ & Totaal \\
\hline $\begin{array}{l}\text { Uitleg over de medische behande- } \\
\text { ling }(n=150)^{*}\end{array}$ & 49 & 0 & 51 & $\begin{array}{c}100 \\
(\mathrm{n}=71)\end{array}$ & 68 & 0 & 32 & $\begin{array}{c}100 \\
(\mathrm{n}=79)\end{array}$ \\
\hline $\begin{array}{l}\text { Aanwezigheid van een intensive } \\
\text { care medewerker tijdens het eerste } \\
\text { bezoek }(n=141)^{*}\end{array}$ & 61 & 33 & 6 & $\begin{array}{c}100 \\
(n=70)\end{array}$ & 75 & 14 & 11 & $\begin{array}{c}100 \\
(n=71)\end{array}$ \\
\hline $\begin{array}{l}\text { Aanwezigheid van een contact- } \\
\text { persoon }(n=138)\end{array}$ & 63 & 0 & 37 & $\begin{array}{c}100 \\
(n=70)\end{array}$ & 49 & 0 & 51 & $\begin{array}{c}100 \\
(n=68)\end{array}$ \\
\hline $\begin{array}{l}\text { Informatie over overplaatsing van de } \\
\text { patient }(n=36)\end{array}$ & 68 & 0 & 32 & $\begin{array}{c}100 \\
(n=25)\end{array}$ & 64 & 0 & 36 & $\begin{array}{c}100 \\
(n=11)\end{array}$ \\
\hline $\begin{array}{l}\text { Ondersteuning van een intensive } \\
\text { care medewerker }(n=95)\end{array}$ & 76 & 0 & 24 & $\begin{array}{c}100 \\
(n=41)\end{array}$ & 78 & 0 & 22 & $\begin{array}{c}100 \\
(n=54)\end{array}$ \\
\hline Uitleg over de apparatuur $(n=99)$ & 52 & 0 & 48 & $\begin{array}{c}100 \\
(n=42)\end{array}$ & 56 & 0 & 44 & $\begin{array}{c}100 \\
(n=57)\end{array}$ \\
\hline $\begin{array}{l}\text { Kunnen spreken over ervaringen en } \\
\text { gevoelens }(n=41)\end{array}$ & 28 & 0 & 72 & $\begin{array}{c}100 \\
(n=18)\end{array}$ & 30 & 0 & 70 & $\begin{array}{c}100 \\
(n=23)\end{array}$ \\
\hline
\end{tabular}

${ }^{*} p<.005$

\subsection{Typen familieleden op de intensive care}

Zoals eerder in dit hoofdstuk is beschreven (7.2) kunnen in principe vier typen familieleden van intensive care patiënten op de intensive care worden onderscheiden. Drie typen vinden de behoefte-items belangrijk (type 1,2,3) en één type (type 4) vindt de behoefte-items niet belangrijk.

Aangetoond is dat de typen familieleden $1 \mathrm{t} / \mathrm{m} 3$ (familieleden die de behoeften belangrijk vinden) over het algemeen meer voorkomen dan type 4 familieleden (familieleden die de behoeften niet belangrijk vinden). Uitzondering is de behoefte om te kunnen spreken over ervaringen en gevoelens (tabel 7.2).

Wanneer gekeken wordt naar de verdeling van typen familieleden op behoeftecategorieniveau blijkt dat een duidelijk verschil te zien (tabel 7.5) is tussen behoeften op het gebied van ondersteuning (aanwezigheid tijdens het eerste bezoek aan de patiënt, ondersteuning door een intensive care medewerker en het kunnen spreken over ervaringen en gevoelens) en behoeften op het gebied van informatie (informatie over de overplaatsing van de patiënt, aanwezigheid van een contactpersoon, uitleg over de apparatuur en uitleg over de medische behandeling). De type 1-, 2-, en 3-familieleden (familieleden die behoeften belangrijk vinden) komen bij informatiebehoeften gemiddeld meer voor $(71 \%)$ dan bij behoeften op het gebied van ondersteuning (53\%). Dit komt overeen met de resultaten uit hoofdstuk 5 , waaruit blijkt dat de gemiddelde score op behoeften van familieleden aan informatie hoger is dan de gemiddelde score op behoeften aan ondersteuning. 
Bij de behoeften in de categorie ondersteuning (tabel 7.5) is de verdeling tussen het aantal typen 1, 2 en 3 (familieleden die behoeften belangrijk vinden) ten opzichte van type 4 (familieleden die behoeften niet belangrijk vinden) bijna gelijk (gemiddeld $53 \%$ typen 1,2 en 3 , ten opzichte van gemiddeld $47 \%$ type 4 ). Hieruit kan worden afgeleid dat, met betrekking tot de drie behoefte-items binnen de categorie ondersteuning, slechts een kleine meerderheid van de familieleden op de intensive care belang hecht aan ondersteuning op de intensive care.

Ten opzichte van behoeften aan informatie is het verschil tussen het aantal typen familieleden aanmerkelijk groter. Hier is gemiddeld $71 \%$ getypeerd in type 1,2 , of 3 (familieleden die behoeften belangrijk vinden), ten opzichte van gemiddeld $29 \%$ dat getypeerd is in type 4 (familieleden die behoeften niet belangrijk vinden). Hieruit kan worden afgeleid dat een duidelijke meerderheid van de getypeerde familieleden behoeften aan informatie belangrijk vindt. Tot slot valt uit tabel 7.2 af te leiden dat familieleden behoeften aan informatie belangrijker vinden dan behoeften aan ondersteuning. Dit komt overeen met de bevindingen uit hoofdstuk 5 .

Tabel 7.5 Overzicht typologie totale onderzoeksgroep (\%).

\begin{tabular}{|l|c|c|c|}
\hline & Type 1,2,3 & Type 4 & Totaal \\
\hline Informatie & 71 & 29 & 100 \\
\hline Ondersteuning & 53 & 47 & 100 \\
\hline Totaal & 62 & 38 & 100 \\
\hline
\end{tabular}

\subsection{De rol van de verpleegkundige}

Zoals uit paragraaf 7.3 blijkt, vinden familieleden van intensive care patiënten de rol van de verpleegkundige als het gaat om behoeften aan ondersteuning en informatie belangrijk. In beide groepen familieleden (familieleden van hartoperatiepatiënten en overige intensive care patiënten) gaat de voorkeur over het algemeen uit naar de verpleegkundige als het gaat om het voorzien in behoeften. Uitzondering is hier de behoefte aan uitleg over de medische behandeling in de groep familieleden van overige intensive care patiënten. Deze groep geeft, voor uitleg over de medische behandeling, de voorkeur aan de arts.

Om de vraag te beantwoorden welke rol de verpleegkundige speelt, is nogmaals gekeken naar tabel 7.4. Hierin is te zien dat alleen voor de type 1 familieleden de gewenste interventies door de gewenste behoefteverstrekkers zijn uitgevoerd. Voor de type 2 familieleden zijn wel de gewenste interventies uitgevoerd, echter niet door gewenste behoefteverstrekker. Voor de type 3 familieleden zijn de gewenste interventies gericht op behoeften aan ondersteuning en informatie niet uitgevoerd. Type 4 wordt verder buiten beschouwing gelaten, omdat dit type familielid geen belang hecht aan de behoeften. 
Vervolgens zijn uit de type-1 familieleden de typen geselecteerd die behoeften belangrijk vinden en waarvan de gewenste en feitelijke behoefteverstrekker de verpleegkundige is. Dit type familielid wordt type V(erpleegkundige) genoemd. Er wordt onderscheid gemaakt tussen de items binnen de categorieën "informatie en ondersteuning".

Als het gaat om behoefte aan informatie blijkt uit tabel 7.6 dat gemiddeld $59 \%$ van de familieleden in type $\mathrm{V}$ is ondergebracht. Dit betekent dat meer dan de helft van de familieleden informatie krijgt van de gewenste behoefteverstrekker (verpleegkundige). Ondanks het gegeven dat $41 \%$ van de familieleden door een andere discipline of helemaal niet geïnformeerd worden kan hieruit worden afgeleid dat, met betrekking tot behoeften aan informatie, familieleden in de meeste situaties daadwerkelijk worden geïnformeerd. Over het algemeen komen deze bevindingen, met uitzondering van de behoefte aan uitleg over de medische behandeling, in beide onderzoeksgroepen overeen.

Tabel 7.6 Familietypering, de rol van de verpleegkundige (\%)

\begin{tabular}{|c|c|c|c|}
\hline 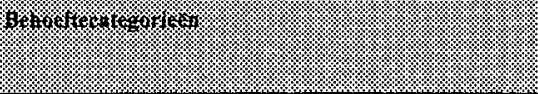 & \%) & 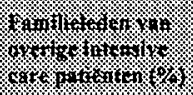 & 6.6.4. \\
\hline & Type V & Type V & Type V \\
\hline $\begin{array}{l}\text { Informatie } \\
\text { Informatie over de overplaatsing van de patient ( } n=36) \\
\text { Aanwezigheid van een contactpersoon }(n=138) \\
\text { Uitleg over de apparatur }(n=99) \\
\text { Uitleg over de medische behandeling }(n=150)^{*}\end{array}$ & $\begin{array}{l}58 \\
68 \\
63 \\
52 \\
49\end{array}$ & $\begin{array}{l}59 \\
64 \\
48 \\
56 \\
68\end{array}$ & $\begin{array}{l}59 \\
66 \\
56 \\
54 \\
59\end{array}$ \\
\hline $\begin{array}{l}\text { Ondersteuning } \\
\text { Aanwezigheid tijdens het eerste bezoek ( } n=141) \\
\text { Ondersteuning van een intensive care medewerker }(n=95) \\
\text { Kunnen spreken over ervaringen en gevoelens }(n=41)\end{array}$ & $\begin{array}{l}55 \\
61 \\
76 \\
28\end{array}$ & $\begin{array}{l}61 \\
75 \\
78 \\
30\end{array}$ & $\begin{array}{l}\mathbf{5 8} \\
68 \\
77 \\
29\end{array}$ \\
\hline
\end{tabular}

$*\left(\chi^{2}=7.73 ; d f=1 ; p=.00\right)$

Tussen de groepen familieleden van hartoperatiepatiënten en overige intensive care patiënten is alleen een verschil aangetoond met betrekking tot de behoefte aan uitleg over de medische behandeling. In de groep familieleden van overige intensive care patiënten komt het type $\mathrm{V}$ duidelijk meer $\left(\chi^{2}=7.73 ; \mathrm{df}=1 ; \mathrm{p}=.00\right)$ voor $(68 \%)$ dan in de groep familieleden van hartoperatiepatiënten (49\%). Hieruit kan worden afgeleid dat familieleden van overige intensive care patiënten duidelijk vaker door de gewenste behoefteverstrekker worden geïnformeerd, dan familieleden van hartoperatiepatiënten.

Op het gebied van behoeften aan ondersteuning komt type $\mathrm{V}$ in $58 \%$ van de gevallen voor. Dit wil zeggen dat $58 \%$ van de familieleden daadwerkelijk ondersteuning krijgen op de intensive care van de verpleegkundige. Duidelijk wordt dat familieleden in de meeste gevallen daadwerkelijk ondersteuning krijgen van de gewenste behoefteverstrekker (verpleegkundige). Het overige percentage ( $42 \%$ ) krijgt ondersteuning van een andere (niet gewenste) discipline of krijgt geen ondersteuning. Met betrekking tot de type $V$ familieleden is geen verschil aangetoond tussen de beide onderzoeksgroepen. 
Verpleegkundigen pakken met betrekking tot behoeften aan informatie en ondersteuning van familieleden over het algemeen de handschoen op (respectievelijk $59 \%$ en $58 \%$ ). Toch wordt een percentage van gemiddeld $42 \%$ van de familieleden met behoeften aan ondersteuning op de intensive care niet of door een andere dan de gewenste discipline ondersteund. Wanneer het gaat om informatie op de intensive care, wordt $41 \%$ van de familieleden niet of door een andere dan de gewenste discipline geïnformeerd.

\subsection{Samenvatting}

In dit hoofdstuk zijn familieleden getypeerd op grond van specifieke behoeften aan ondersteuning en informatie. Daar waar de arts en de gastvrouw een relatief kleine rol spelen binnen de wensen van familieleden speelt de verpleegkundige de hoofdrol. Op het gebied van behoeften aan ondersteuning wordt deze positie door de verpleegkundigen in $58 \%$ van de gevallen daadwerkelijk ingevuld. Wanneer het gaat om informatie, vullen verpleegkundigen in $59 \%$ van de gevallen de gewenste positie in. 


\section{TYPOLOGIE EN BEÏNVLOEDENDE FACTOREN}

\subsection{Inleiding}

In dit hoofdstuk wordt verder ingegaan op de bevindingen uit hoofdstuk zeven. Hieruit blijkt dat familieleden van intensive care patiënten de verpleegkundige een belangrijke rol toekennen als het gaat om de voorziening in behoeften aan ondersteuning en informatie op de intensive care. Een kleinere rol wordt toegekend aan de arts en de gastvrouw. Bovenstaande bevindingen hebben er toe geleid de familieleden opnieuw te typeren in type A (het type familielid dat de voorkeur geeft aan de verpleegkundige), type B (het type familielid dat de voorkeur geeft aan een andere discipline) en type $\mathrm{C}$ (het type familielid dat geen behoeften heeft op het gebied van ondersteuning en informatie (tabel 8.1).

In dit hoofdstuk wordt de invloed van sociaal-demografische-, intensive care gelieerde-, ziektegebonden- en copingvariabelen op de typen familieleden achtereenvolgens besproken. Hierbij wordt wederom het onderscheid gemaakt tussen familieleden van hartoperatiepatiënten en familieleden van overige intensive care patiënten. De resultaten zullen steeds per onderzoeksgroep worden gepresenteerd.

Tabel 8.1 Typen familieleden

\begin{tabular}{|l|l|}
\hline Type A & Geeft de voorkeur aan de verpleegkundige \\
Type B & Geeft de voorkeur aan een andere discipline \\
Type C & Heeft geen behoefte \\
\hline
\end{tabular}

\subsection{Invloed van sociaal-demografische factoren}

\section{Inleiding}

Van de zeven (hoofdstuk 3), in deze studie betrokken, sociaal-demografische factoren, zijn drie factoren van invloed op de typen familieleden. De relatie die het familielid heeft met de patiënt is van invloed in de groep familieleden van overige intensive care patiënten. Hiernaast is de leeftijd van de familieleden en het gebied waar het familielid woonachtig is, van invloed in de totale onderzoeksgroep. Deze factoren zullen in de volgende paragrafen worden besproken.

\section{Relatie}

Zoals tabel 8.2 toont is de relatie, die het familielid in de groep familieleden van overige intensive care patiënten heeft met de patiënt, van invloed $\left(\chi^{2}=6.49, \mathrm{df}=2, \mathrm{p}=.03\right)$ op de behoefte aan aanwezigheid van een intensive care medewerker tijdens het eerste bezoek aan de patiënt. 
Over het algemeen hebben partners meer behoefte aan aanwezigheid van een andere discipline $(46 \%)$ dan andere familieleden (21\%). Opvallend is dat andere familieleden duidelijk meer voorkeur hebben voor de verpleegkundige (50\%) dan partners (40\%). In de totale onderzoeksgroep en in de groep familieleden van hartoperatiepatiënten is geen verschil tussen partners en andere familieleden aangetoond.

Tabel 8.2 Invloed van relatie op de behoeften van familieleden aan aanwezigheid van een intensive care medewerker tijdens het eerste bezoek aan de patiënt op de intensive care (\%).

\begin{tabular}{|c|c|c|c|c|}
\hline 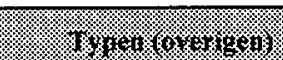 & 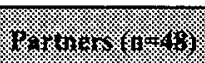 & 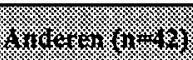 & (1) & 8 \\
\hline $\begin{array}{l}\text { Aanwezigheid eerste bezoek } \\
\text { A (Verpleegkundige) } \\
\text { B (Andere discipline) } \\
\text { C (Niemand) } \\
\text { Totaal }\end{array}$ & $\begin{array}{r}40 \\
46 \\
14 \\
100\end{array}$ & $\begin{array}{r}50 \\
21 \\
29 \\
100\end{array}$ & 2 & .03 \\
\hline
\end{tabular}

\section{Leeftijd}

In tabel 8.2.1 is te zien dat de grootste groep familieleden, uit de totale onderzoeksgroep, die geïnformeerd wil worden over de medische behandeling van de patiënt een leeftijd heeft die varieert van 20 tot 40 jaar. In deze groep wil $50 \%$ door de verpleegkundige geïnformeerd worden. Ook in de groep familieleden met een leeftijd van 41 tot 60 jaar willen de meeste familieleden geïnformeerd worden over de medische behandeling van de patiënt.

Opvallend is dat deze groep vaker $\left(\chi^{2}=9.14, \mathrm{df}=4, \mathrm{p}=.05\right)$ de voorkeur geeft aan informatie door een andere discipline (54\%) dan de andere leeftijdscategorieën ( $41 \%$ en $32 \%)$.

Familieleden in de leeftijdscategorie ouder dan 60 jaar geven eveneens te kennen de voorkeur te geven aan de verpleegkundige als het gaat om informatie over de medische behandeling van de patiënt (47\%). In de leeftijdscategorie $>61$ jaar vindt $21 \%$ informatie over de medische behandeling niet belangrijk. Hierdoor onderscheiden zij zich van de andere leeftijdscategorieën waarbij respectievelijk $9 \%$ en $11 \%$ aangeven informatie over de medische behandeling niet belangrijk te vinden.

Tabel 8.2.1 Invloed van leeftijd op de behoeften van familieleden aan informatie over de medische behandeling van de patient op de intensive care (\%)

\begin{tabular}{|c|c|c|c|c|c|}
\hline y. & (1) & 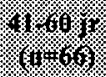 & 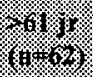 & 4 & $\%$ \\
\hline $\begin{array}{l}\text { Informatie medische behandeling } \\
\text { Type A (Verpleegkundige) } \\
\text { Type B (Andere discipline) } \\
\text { Type C (Niemand) } \\
\text { Totaal }\end{array}$ & $\begin{array}{r}50 \\
41 \\
9 \\
100\end{array}$ & $\begin{array}{r}35 \\
54 \\
11 \\
100\end{array}$ & $\begin{array}{r}47 \\
32 \\
21 \\
100\end{array}$ & 4 & .05 \\
\hline
\end{tabular}

Opvallend is dat, naarmate de leeftijd van de respondenten stijgt, de behoefte aan informatie afneemt. 


\section{Woongebied}

In tabel 8.2.2 is te zien dat, in de totale onderzoeksgroep, familieleden uit Gelderland en Overijssel vaker aangeven geen informatie over de medische behandeling te wensen (24\%) dan familieleden uit Utrecht (10\%) en de rest van Nederland (9\%).

In deze groep komt type $\mathrm{B}$ (wil de informatie over de medische behandeling door een andere discipline) minder $\left(\chi^{2}=9.44, \mathrm{df}=4, \mathrm{p}=.05\right)$ voor $(29 \%)$ dan bij familieleden uit Utrecht $(47 \%)$ en de rest van Nederland (51\%).

Tabel 8.2.2 Invloed van woongebied op de behoeften van familieleden aan informatie over de medische behandeling van de patiënt op de intensive care (\%).

\begin{tabular}{|c|c|c|c|c|c|}
\hline 1\%. & 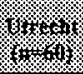 & 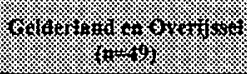 & Wrow & 4 & $\%$ \\
\hline $\begin{array}{l}\text { Informatie medische behandeling } \\
\text { Type A (Verpleegkundige) } \\
\text { Type B (Andere discipline) } \\
\text { Type C (Niemand) } \\
\text { Totaal }\end{array}$ & $\begin{array}{r}43 \\
47 \\
10 \\
100\end{array}$ & $\begin{array}{r}47 \\
29 \\
24 \\
100\end{array}$ & $\begin{array}{r}40 \\
51 \\
9 \\
100\end{array}$ & 4 & .05 \\
\hline
\end{tabular}

\subsection{Invloed van intensive care gelieerde factoren}

\section{Inleiding}

Zoals in hoofdstuk 3 is beschreven zijn vier intensive care gelieerde factoren in dit onderzoek betrokken. Hiervan zijn twee factoren van invloed op de typen familieleden. De wachttijd op opname van de patiënt op de intensive care is van invloed in de groep familieleden van overige intensive care patiënten en het meemaken van een onplezierige ervaring op de intensive care is van invloed in zowel de totale onderzoeksgroep als in de groep familieleden van hartoperatiepatiënten. In de volgende paragrafen worden de resultaten achtereenvolgens gepresenteerd.

\section{Wachttijd op opname}

In de groep familieleden van overige intensive care patiënten is de wachttijd op opname van de patiënt op de intensive care van invloed op de behoefte aan een contactpersoon (tabel 8.3) en op de behoefte aan aanwezigheid van een intensive care medewerker bij het eerste bezoek aan de patiënt op de intensive care. In tabel 8.3 is te zien dat familieleden van overige intensive care patiënten die met een wachttijd op opname geconfronteerd zijn, duidelijk $\left(\chi^{2}=9.26, \mathrm{df}=2, \mathrm{p}=.00\right)$ minder behoefte hebben aan een contactpersoon ( $\left.47 \%\right)$ dan familieleden die niet met een wachttijd zijn geconfronteerd (18\%). Opvallend is hier dat familieleden in beide groepen de voorkeur geven aan een niet verpleegkundig contactpersoon (andere discipline). 
Tabel 8.3 Invloed van wachttijd op opname op de behoefte van familieleden aan een contactpersoon en aanwezigheid van een intensive care medewerker tijdens het eerste bezoek aan de patiënt (\%).

\begin{tabular}{|c|c|c|c|c|}
\hline \%(1) & 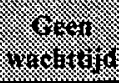 & \% & (1) & 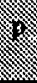 \\
\hline $\begin{array}{l}\text { Behoefte aan een contactpersoon } \\
\text { Type A (Verpleegkundige) } \\
\text { Type B (Andere discipline) } \\
\text { Type C (Niemand) } \\
\text { Totaal }\end{array}$ & $\begin{array}{c}(\mathbf{n}=62) \\
26 \\
56 \\
18 \\
100\end{array}$ & $\begin{array}{c}(\mathbf{n}=\mathbf{3 2}) \\
12 \\
41 \\
47 \\
100\end{array}$ & 2 & .00 \\
\hline $\begin{array}{l}\text { Behoefte aan aanwezigheid intensive care medewerker } \\
\text { Type A (Verpleegkundige) } \\
\text { Type B (Andere discipline) } \\
\text { Type C (Niemand) } \\
\text { Totaal }\end{array}$ & $\begin{array}{c}(n=59) \\
58 \\
22 \\
20 \\
100\end{array}$ & $\begin{array}{c}(\mathbf{n}=31) \\
19 \\
58 \\
23 \\
100\end{array}$ & 2 & .00 \\
\hline
\end{tabular}

Met betrekking tot de behoefte aan aanwezigheid van een intensive care medewerker tijdens het eerste bezoek aan de patiënt op de intensive care is een duidelijk $\left(\chi^{2}=14.4, \mathrm{df}=2, \mathrm{p}=.00\right)$ verschil te zien tussen familieleden die met een wachttijd zijn geconfronteerd en familie-leden die niet met een wachttijd zijn geconfronteerd. Familieleden van patiënten met een wachttijd geven de voorkeur aan de aanwezigheid van een andere discipline (58\%) tijdens het eerste bezoek aan de patiënt. Familieleden van patiënten zonder wachttijd geven de voorkeur aan de aanwezigheid van de verpleegkundige (58\%) tijdens het eerste bezoek. Wachttijd is niet van invloed op type $\mathrm{C}$ (vindt de aanwezigheid van een intensive care medewerker tijdens het eerste bezoek niet belangrijk).

\section{Onplezierige ervaring}

Een onplezierige ervaring is, in de totale onderzoeksgroep, duidelijk van invloed $\left(\chi^{2}=9.18\right.$, $\mathrm{df}=2, \mathrm{p}=.01$ ) op de behoefte aan aanwezigheid van een verpleegkundige tijdens het eerste bezoek aan de patiënt op de intensive care. In tabel 8.3.1 is te zien dat familieleden met een onplezierige ervaring vaker de voorkeur geven aan de aanwezigheid van een andere discipline (42\%) dan familieleden die geen onplezierige ervaring hebben gehad $(20 \%)$, terwijl familieleden die geen onplezierige ervaring hebben gehad meer de voorkeur geven aan de aanwezigheid van de verpleegkundige $(58 \%)$ dan familieleden met een onplezierige ervaring op de intensive care (41\%). Type C (vindt de aanwezigheid van een intensive care medewerker niet belangrijk) komt meer voor bij familieleden die geen onplezierige ervaring hebben gehad $(22 \%)$. 
Tabel 8.3.1 Invloed van een onplezierige ervaring op de behoeften van familieleden aan aanwezigheid van een intensive care medewerker tijdens het eerste bezoek aan de patiënt (\%).

\begin{tabular}{|l|c|c|c|c|}
\hline (1) & & & \\
\hline
\end{tabular}

Een onplezierige ervaring op de intensive care, is, in de groep familieleden van hartoperatiepatiënten, eveneens van invloed $\left(\chi^{2}=8.67, \mathrm{df}=2, \mathrm{p}=.01\right)$ op de behoefte aan aanwezigheid van een intensive care medewerker tijdens het eerste bezoek aan de patiënt op de intensive care. In tabel 8.3.1 is te zien dat familieleden die aangeven geen onplezierige ervaring gehad te hebben, duidelijk meer voorkeur hebben voor de verpleegkundige $(67 \%)$ dan familieleden met een onplezierige ervaring op de intensive care (42\%). Opvallend is dat familieleden met een onplezierige ervaring meer voorkeur hebben voor een andere discipline (44\%) dan familieleden die aangeven geen onplezierige ervaring gehad te hebben (14\%). Type $\mathrm{C}$ (heeft geen behoefte aan aanwezigheid van een intensive care medewerker) komt meer voor bij familieleden die geen onplezierige ervaring hadden (19\%) dan bij familieleden die dat wel hadden $(14 \%)$. In de groep familieleden van overige intensive care patiënten wordt geen verschil gevonden.

Met betrekking tot de behoefte van familieleden aan ondersteuning op de intensive care en de behoefte aan informatie over de overplaatsing van de patiënt, is, in de totale onderzoeksgroep, dezelfde tendens te zien als bij de behoefte aan aanwezigheid bij het eerste bezoek aan de patiënt op de intensive care (tabel 8.3.1). In tabel 8.3.2 is te zien dat familieleden met een onplezierige ervaring op de intensive care duidelijk vaker $\left(\chi^{2}=6.14, \mathrm{df}=2, \mathrm{p}=.04\right)$ de voorkeur geven aan ondersteuning door een andere discipline (type B, 17\%) dan familieleden die geen onplezierige ervaring meemakkten (5\%). Familieleden die geen onplezierige ervaring hadden geven vaker de voorkeur aan ondersteuning door de verpleegkundige (type A, 49\%) dan familieleden met een onplezierige ervaring ( $40 \%)$.

Type $\mathrm{C}$ (vindt ondersteuning op de intensive care niet belangrijk) komt ongeveer evenveel voor in beide groepen. 
Tabel 8.3.2 Invloed van een onplezierige ervaring op de behoeften van familieleden aan ondersteuning op de intensive care en behoeften aan informatie over de overplaatsing van de patiënt (\%).

\begin{tabular}{|c|c|c|c|c|}
\hline Kot & $8 x_{4}$ & $\frac{1}{4}$ & 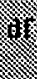 & 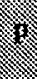 \\
\hline $\begin{array}{l}\text { Ondersteuning op de intensive care } \\
\text { Type A (Verpleegkundige) } \\
\text { Type B (Andere discipline) } \\
\text { Type C (Niemand) } \\
\text { Totaal }\end{array}$ & $\begin{array}{c}(n=92) \\
40 \\
17 \\
43 \\
100\end{array}$ & $\begin{array}{c}(n=77) \\
49 \\
5 \\
46 \\
100\end{array}$ & 2 & .04 \\
\hline $\begin{array}{l}\text { Informatie over overplaatsing } \\
\text { Type A (Verpleegkundige) } \\
\text { Type B (Andere discipline) } \\
\text { Type C (Niemand) } \\
\text { Totaal }\end{array}$ & $\begin{array}{c}(n=24) \\
25 \\
29 \\
46 \\
100\end{array}$ & $\begin{array}{c}(\mathrm{n}=\mathbf{2 8}) \\
64 \\
18 \\
18 \\
100\end{array}$ & 2 & .01 \\
\hline
\end{tabular}

Familieleden met een onplezierige ervaring geven vaker de voorkeur aan een andere discipline (type B) als het gaat om informatie over de overplaatsing van de patiënt naar een andere afdeling of ziekenhuis (29\%) dan familieleden die geen onplezierige ervaring hadden (18\%). Opvallend is, dat familieleden die aangeven geen onplezierige ervaring te hebben gehad duidelijk $\left(\chi^{2}=8.32, \mathrm{df}=2, \mathrm{p}=.01\right)$ de voorkeur geven aan informatie over de overplaatsing van de patiënt door de verpleegkundige (type A, 64\%). Bij familieleden die wel een onplezierige ervaring hadden komt type B duidelijk meer (29\%) voor, dan bij familieleden die geen onplezierige ervaring hebben meegemaakt (18\%). Type $\mathrm{C}$ (vindt informatie over de overplaatsing van de patiënt niet belangrijk) komt duidelijk meer voor bij familieleden met een onplezierige ervaring (46\%) dan bij familieleden die geen onplezierige ervaring hadden $(18 \%)$.

Tot slot is ook hier gekeken waaruit de onplezierige ervaringen van familieleden bestaan in relatie tot de gewenste behoefteverstrekker. Familieleden, met een onplezierige ervaring, die de voorkeur geven aan de aanwezigheid van een verpleegkundige tijdens het eerste bezoek aan de patiënt, geven aan, met name een onplezierige ervaring te hebben gehad op het gebied van patiëntgebonden factoren (aanblik van de patiënt en apparatuur) en op het gebied van organisatiegebonden factoren (wachttijden en organisatie van de intensive care).

Familieleden, met een onplezierige ervaring, die de voorkeur aan de verpleegkundige geven als het gaat om ondersteuning op de intensive care, geven met name aan een onplezierige ervaring te hebben gehad, gericht op organisatiegebonden factoren (wachttijden en organisatie van de intensive care).

Familieleden, met een onplezierige ervaring, die door de verpleegkundige geïnformeerd willen worden over een eventuele overplaatsing van de patiënt naar een andere afdeling of ziekenhuis, geven eveneens aan een onplezierige ervaring te hebben gehad, gericht op organisatiegebonden factoren. 


\subsection{Invloed van ziektegebonden factoren}

\section{Inleiding}

Van de vijf ziektegebonden factoren (hoofdstuk 3) zijn drie factoren van invloed op de typen familieleden. De opnamefrequentie is van invloed in de totale onderzoeksgroep. Het feit of de patiënt mechanisch beademd wordt is, evenals het feit of de opname gepland is, van invloed in de groep familieleden van overige intensive care patiënten. De resultaten worden in de volgende paragrafen besproken.

\section{Opnamefrequentie}

In de totale onderzoeksgroep is de opnamefrequentie van invloed $\left(\chi^{2}=6.67, \mathrm{df}=2, \mathrm{p}=.03\right)$ op de behoefte aan informatic over de overplaatsing van de patiënt naar een andere afdeling of ziekenhuis.

Tabel 8.4 Invloed van opnamefrequentie op de behoefte van familieleden aan informatie over de overplaatsing van de patiěnt (\%).

\begin{tabular}{|c|c|c|c|c|}
\hline 6) & 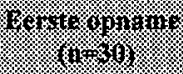 & 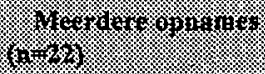 & 16 & 3). \\
\hline $\begin{array}{l}\text { Informatie overplaatsing } \\
\text { Type A (Verpleegkundige) } \\
\text { Type B (Andere discipline) } \\
\text { Type C (Niemand) } \\
\text { Totaal }\end{array}$ & $\begin{array}{r}57 \\
27 \\
16 \\
100\end{array}$ & $\begin{array}{r}32 \\
18 \\
50 \\
100\end{array}$ & 2 & .03 \\
\hline
\end{tabular}

In tabel 8.4 is te zien dat type $\mathrm{C}$ (vindt informatie over de overplaatsing niet belangrijk) duidelijk meer voorkomt (50\%) bij familieleden van patiënten die eerder opgenomen zijn geweest op de intensive care dan bij familieleden van patiënten die voor de eerste keer op de intensive care zijn opgenomen (16\%). Hiernaast geven familieleden van patiënten die voor de eerste keer zijn opgenomen op de intensive care vaker de voorkeur aan de verpleegkundige (type $A, 57 \%$ ) als het gaat om informatie over de overplaatsing dan aan een andere discipline (type B ,27\%). Ook familieleden van patiënten die eerder op de intensive care zijn opgenomen geven vaker de voorkeur aan de verpleegkundige (32\%) dan aan een andere discipline $(18 \%)$.

\section{Mechanische ventilatie}

In de groep familieleden van overige intensive care patiënten is het feit dat de patiënt beademd wordt (mechanische ventilatie), zowel van invloed op de behoefte aan een contactpersoon op de intensive care $\left(\chi^{2}=6.32, \mathrm{df}=2, \mathrm{p}=.04\right)$, als op de behoefte aan aanwezigheid van een intensive care medewerker tijdens het eerste bezoek aan de patiënt $\left(\chi^{2}=6.02, \mathrm{df}=2, \mathrm{p}=.04\right)$. 
In tabel 8.4.1 is te zien dat familieleden van patiënten die beademd worden duidelijk vaker kiezen voor een andere discipline als contactpersoon (type B, 62\%) dan familieleden van patiënten die spontaan ademen (41\%). Familieleden van patiënten die spontaan ademen geven eerder de voorkeur aan de verpleegkundige als contactpersoon (type A, 31\%) dan familieleden van patiënten die beademd worden ( $11 \%$ ). Type $C$ (vindt een contactpersoon niet belangrijk) komt in beide groepen ongeveer gelijk voor.

Tabel 8.4.1 Invloed van mechanische ventilatie op de behoefte van familieleden aan een contactpersoon en de behoefte van familieleden aan aanwezigheid van een intensive care medewerker tijdens het eerste bezoek aan de patiënt op de intensive care (\%).

\begin{tabular}{|c|c|c|c|c|}
\hline / & 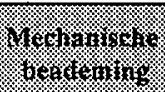 & 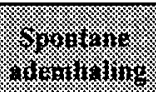 & iz & 8 \\
\hline $\begin{array}{l}\text { Behoefte aan een contactpersoon } \\
\text { Type A (Verpleegkundige) } \\
\text { Type B (Andere discipline) } \\
\text { Type C (Niemand) } \\
\text { Totaal }\end{array}$ & $\begin{array}{c}(\mathrm{n}=45) \\
11 \\
62 \\
27 \\
100\end{array}$ & $\begin{array}{c}(n=49) \\
31 \\
41 \\
28 \\
100\end{array}$ & 2 & .04 \\
\hline $\begin{array}{l}\text { Aanwezigheid eerste bezoek } \\
\text { Type A (Verpleegkundige) } \\
\text { Type B (Andere discipline) } \\
\text { Type C (Niemand) } \\
\text { Totaal }\end{array}$ & $\begin{array}{c}(\mathrm{n}=40) \\
55 \\
35 \\
10 \\
100\end{array}$ & $\begin{array}{c}(n=50) \\
36 \\
34 \\
30 \\
100\end{array}$ & 2 & .04 \\
\hline
\end{tabular}

Mechanische beademing van de patiënt is, in de groep familieleden van overige intensive care patiënten, eveneens van invloed op de behoefte aan aanwezigheid van een intensive care medewerker tijdens het eerste bezoek aan de patiënt op de intensive care.

Zoals tabel 8.4.1 toont komt type $\mathrm{C}$ (vindt de aanwezigheid van een intensive care medewerker niet belangrijk) meer voor bij familieleden van patiënten die spontaan ademen (30\%) dan bij familieleden van patiënten die beademd worden (10\%).

Familieleden van beademde patiënten hebben duidelijk meer voorkeur voor de aanwezigheid van de verpleegkundige (type A) tijdens het eerste bezoek (55\%) dan familieleden van patiënten die spontaan ademen (36\%). Type B (geeft de voorkeur aan aanwezigheid van een andere discipline) komt in beide groepen gelijk voor.

\section{Planning van de opname}

Het feit of de opname gepland is of niet (het betreft dan een spoedopname) is, alleen in de groep familieleden van overige intensive care patiënten, van invloed ( $\chi 2=14.79, \mathrm{df}=2, \mathrm{p}=.00$ ) op de behoefte van familieleden aan aanwezigheid van een intensive care medewerker tijdens het eerste bezoek aan de patiënt op de intensive care. 
Tabel 8.4.2 Invloed van planning van de opname op de behoefte van familieleden aan aanwezigheid van een intensive care medewerker tijdens het eerste bezoek aan de patiènt op de intensive care (\%)

\begin{tabular}{|c|c|c|c|c|}
\hline 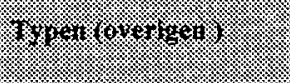 & 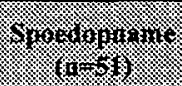 & (8) & $1 \%$ & 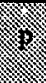 \\
\hline $\begin{array}{l}\text { Aanwezigheid eerste bezoek } \\
\text { Type A (Verpleegkundige) } \\
\text { Type B (Andere discipline) } \\
\text { Type C (Niemand) } \\
\text { Totaal }\end{array}$ & $\begin{array}{r}57 \\
18 \\
25 \\
100\end{array}$ & $\begin{array}{r}28 \\
56 \\
16 \\
100\end{array}$ & 2 & .00 \\
\hline
\end{tabular}

In tabel 8.4.2 is te zien dat familieleden van patiënten die met spoed opgenomen zijn vaker de voorkeur geven aan de aanwezigheid van de verpleegkundige (type A) tijdens het eerste bezoek $(57 \%)$ dan familieleden van patiënten die gepland zijn opgenomen $(28 \%)$.

Familieleden van patiënten die gepland zijn opgenomen geven vaker de voorkeur aan de aanwezigheid van een andere discipline (type B) tijdens het eerste bezoek (56\%) dan familieleden van patiënten die met spoed zijn opgenomen (18\%).

Type $\mathrm{C}$ (vindt de aanwezigheid van een intensive care medewerker niet belangrijk) komt meer voor bij familieleden van patiënten die met spoed zijn opgenomen $(25 \%)$ dan bij familieleden van patiënten die gepland zijn opgenomen op de intensive care (16\%).

\subsection{Invloed van copinggedrag}

\section{Inleiding}

De vier copingstijlen ("actief aanpakken", "sociale steun zoeken", "afwachten en vermijden" en "palliatief gedrag") zijn van invloed op de typen familieleden. "Actief aanpakken" is van invloed in de totale onderzoeksgroep, "sociale steun zoeken" heeft invloed in de totale onderzoeksgroep en in de groep familieleden van overige intensive care patiënten, "afwachten en vermijden" is eveneens van invloed in de totale onderzoeksgroep en de groep familieleden van overige intensive care patiënten en "palliatief gedrag" beïnvloedt de typen familieleden in de totale onderzoeksgroep en de groep familieleden van hartoperatiepatienten. Achtereenvolgens zullen de resultaten in de volgende paragrafen worden besproken.

\section{Actief aanpakken}

De copingstijl "actief aanpakken" is, in de totale onderzoeksgroep, van invloed op de behoefte van familieleden aan een contactpersoon op de intensive care. In tabel 8.5 is te zien dat familieleden die een hoge score hebben op de copingstijl "actief aanpakken" (3.2) duidelijk $\left(\chi^{2}=7.14, \mathrm{~d} f=2, \mathrm{p}=.02\right)$ vaker de voorkeur geven aan de verpleegkundige als het gaat om een contactpersoon (type A), dan familieleden met een lagere score op "actief aanpakken" (3.0 en 2.8). Deze typen familieleden (B en C) geven de voorkeur aan een andere discipline of willen geen contactpersoon. 
Tabel 8.5 Invloed van de copingstijl "actief aanpakken" op de behoefte van familieleden aan een contactpersoon op de intensive care.

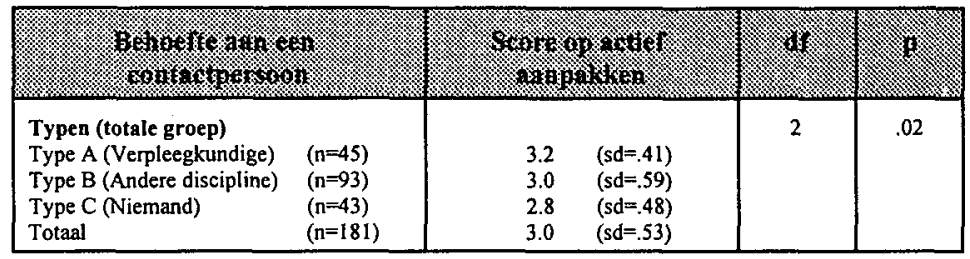

Min. score $=1$

Max. score $=4$

\section{Sociale steun zoeken}

De copingstijl "sociale steun zoeken" is zowel van invloed op de behoefte aan ondersteuning op de intensive care als op de behoefte aan uitleg over de apparatuur die bij de patiënt gebruikt wordt. In tabel 8.5.1 is te zien dat de copingstijl "sociale steun zoeken" van invloed is in de totale onderzoeksgroep en in de groep familieleden van overige intensive care patiënten. In de groep familieleden van hartoperatiepatiënten is deze invloed niet gevonden.

Familieleden uit de totale onderzoeksgroep met een hoge score op de copingstijl "sociale steun zoeken" $(2.5)$, geven duidelijk $\left(\chi^{2}=8.42, \mathrm{df}=2, \mathrm{p}=.01\right)$ vaker de voorkeur aan de verpleegkundige (type $A$ ) als het gaat om ondersteuning op de intensive care. Familieleden met een lagere score ( 2.3 en 2.2 ) geven de voorkeur aan een andere discipline of willen geen ondersteuning op de intensive care (type $\mathrm{B}$ en $\mathrm{C}$ ).

Tabel 8.5.1 Invloed van de copingstijl "sociale steun zoeken" op de behoefte van familieleden aan ondersteuning op de intensive care.

\begin{tabular}{|c|c|c|c|c|c|}
\hline \multicolumn{2}{|c|}{ 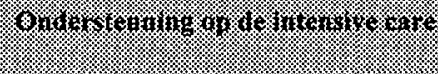 } & \multicolumn{2}{|c|}{ 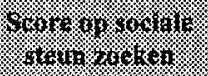 } & 4 & $\gamma$ \\
\hline $\begin{array}{l}\text { Typen (totale groep) } \\
\text { Type A (Verpleegkundige) } \\
\text { Type B (Andere discipline) } \\
\text { Type C (Niemand) } \\
\text { Totaal }\end{array}$ & $\begin{array}{l}(n=75) \\
(n=20) \\
(n=74) \\
(n=169)\end{array}$ & $\begin{array}{l}2.5 \\
2.3 \\
2.2 \\
2.3\end{array}$ & $\begin{array}{l}(s d=.61) \\
(s d=.60) \\
(s d=.59) \\
(s d=.61)\end{array}$ & 2 & .01 \\
\hline $\begin{array}{l}\text { Typen (overigen) } \\
\text { Type A (Verpleegkundige) } \\
\text { Type B (Andere discipline) } \\
\text { Type C (Niemand) } \\
\text { Totaal }\end{array}$ & $\begin{array}{l}(n=42) \\
(n=12) \\
(n=42) \\
(n=96)\end{array}$ & $\begin{array}{l}2.6 \\
2.6 \\
2.3 \\
2.4\end{array}$ & $\begin{array}{l}(s d=.64) \\
(s d=.62) \\
(s d=.57) \\
(s d=.62)\end{array}$ & 2 & .01 \\
\hline
\end{tabular}

Min. score $=I$

Max. score $=4$

Opvallend is dat, in de groep familieleden van overige intensive care patiënten, familieleden met een hoge score op de copingstijl "sociale steun zoeken" geen voorkeur hebben voor een bepaalde behoefteverstrekker met betrekking tot behoeften aan ondersteuning.

Zowel type A als type B hebben een score van 2.6 op de copingstijl "sociale steun zoeken". 
Wel is een duidelijk $\left(\chi^{2}=8.19, \mathrm{df}=2, \mathrm{p}=.01\right)$ verschil aangetoond bij familieleden met een lagere score op "sociale steun zoeken" (2.3). Dit type familielid (type C) wenst geen ondersteuning op de intensive care.

Als het gaat om uitleg over de apparatuur (tabel 8.5.2) die bij de patiënt wordt gebruikt, blijkt dat familieleden met een hoge score op "sociale steun zoeken" duidelijk de voorkeur geven aan de verpleegkundige (type $\mathrm{A}$ ).

Tabel 8.5.2 Invloed van de copingstijl "sociale steun zoeken" op de behoefte van familieleden aan uitleg over de apparatuur die bij de patiënt gebruikt wordt op de intensive care.

\begin{tabular}{|c|c|c|c|c|c|}
\hline (3) & $d 4$ & 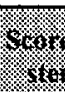 & 30. & 8 & \% \\
\hline $\begin{array}{l}\text { Typen (totale groep) } \\
\text { Type A (Verpleegkundige) } \\
\text { Type C (Niemand) } \\
\text { Totaal }\end{array}$ & $\begin{array}{l}(n=99) \\
(n=90) \\
(n=180)\end{array}$ & $\begin{array}{l}2.5 \\
2.2 \\
2.3\end{array}$ & $\begin{array}{l}(\mathrm{sd}=.64) \\
(\mathrm{sd}=.54) \\
(\mathrm{sd}=.61)\end{array}$ & 1 & .03 \\
\hline $\begin{array}{l}\text { Typen (overigen) } \\
\text { Type A (Verpleegkundige) } \\
\text { Type C (Niemand) } \\
\text { Totaal }\end{array}$ & $\begin{array}{l}(n=57) \\
(n=44) \\
(n=101)\end{array}$ & $\begin{array}{l}2.6 \\
2.2 \\
2.5\end{array}$ & $\begin{array}{l}(\mathrm{sd}=.59) \\
(\mathrm{sd}=.56) \\
(\mathrm{sd}=.61)\end{array}$ & 1 & .01 \\
\hline
\end{tabular}

Min. score $=1$

Max. score $=4$

Dit resultaat is alleen aangetoond in de totale onderzoeksgroep en in de groep familieleden van overige intensive care patiënten. In de totale onderzoeksgroep heeft type A (geeft voorkeur aan de verpleegkundige) een gemiddelde score van 2.5 op de copingstijl "sociale steun zoeken" ten opzichte van type C (wil geen uitleg) die een gemiddelde score van 2.2 op de copingstijl "sociale steun zoeken" heeft $\left(\chi^{2}=4.50, \mathrm{df}=1, \mathrm{p}=.03\right)$.

In de groep familieleden van overige intensive care patiënten is dezelfde tendens te zien.

In deze groep heeft type A (geeft de voorkeur aan de verpleegkundige ) een gemiddelde score van 2.6 op de copingstijl "sociale steun zoeken" ten opzichte van type $C$ (wil geen uitleg) die een gemiddelde score heeft van $2.2\left(\chi^{2}=5.57, \mathrm{df}=1, \mathrm{p}=.01\right)$. Opvallend is dat in beide groepen type $B$ (het type familielid dat de uitleg door een andere discipline wenst) niet voorkomt.

\section{Afwachten en vermijden}

Alleen in de groep familieleden van overige intensive care patiënten beïnvloedt de copingstijl "afwachten en vermijden" de behoefte aan uitleg over de werking van de apparatuur die bij de patiënten gebruikt wordt (tabel 8.5.3). In de totale onderzoeksgroep wordt de behoefte aan aanwezigheid van een intensive care medewerker tijdens het eerste bezoek aan de patiënt door de copingstijl "afwachten en vermijden" beïnvloed (tabel 8.5.3). Opvallend is dat familieleden met een lage score op de copingstijl "afwachten en vermijden" (1.7) duidelijk geen behoefte hebben aan uitleg (type C) over de apparatuur die bij de patiënt gebruikt wordt.

Ook type A (geeft de voorkeur aan de verpleegkundige) heeft, ondanks het statistisch aangetoonde verschil tussen beide typen familieleden $\left(\chi^{2}=4.60, \mathrm{df}=1, \mathrm{p}=.03\right)$ een relatief lage score op de copingstijl "afwachten en vermijden" (1.8). 
Tabel 8.5.3 Invloed van de copingstijl "afwachten en vermijden" op de behoefte van familieleden aan uitleg over de apparatuur en de aanwezigheid van een intensive care medewerker tijdens het eerste bezoek aan de patiënt op de intensive care.

\begin{tabular}{|c|c|c|c|c|c|}
\hline \multicolumn{2}{|c|}{ 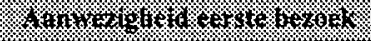 } & \multicolumn{2}{|c|}{ 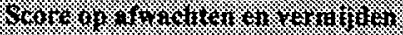 } & 26 & 0 \\
\hline $\begin{array}{l}\text { Typen (totale groep) } \\
\text { Type A (Verpleegkundige) } \\
\text { Type B (Anderen) } \\
\text { Type C (Niernand) } \\
\text { Totaal }\end{array}$ & $\begin{array}{l}(\mathrm{n}=84) \\
(\mathrm{n}=57) \\
(\mathrm{n}=33) \\
(\mathrm{n}=174)\end{array}$ & $\begin{array}{l}1.8 \\
2.1 \\
1.7 \\
1.9\end{array}$ & $\begin{array}{l}(\mathrm{sd}=.57) \\
(\mathrm{sd}=.58) \\
(\mathrm{sd}=.54) \\
(\mathrm{sd}=.58)\end{array}$ & 2 & .01 \\
\hline K(3) & & $(4 \times 10 \times 1 \% 1 \%$ & 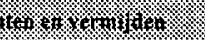 & $\sqrt{18}$ & 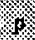 \\
\hline $\begin{array}{l}\text { Typen (overigen) } \\
\text { Type A (Verpleegkundige) } \\
\text { Type C (Niemand) } \\
\text { Totaal }\end{array}$ & $\begin{array}{l}(n=57) \\
(n=44) \\
(n=101)\end{array}$ & $\begin{array}{l}1.8 \\
1.7 \\
1.8\end{array}$ & $\begin{array}{l}(\mathrm{sd}=.58) \\
(\mathrm{sd}=.53) \\
(\mathrm{sd}=.57)\end{array}$ & 1 & .03 \\
\hline
\end{tabular}

Min. score $=I$

Max. score $=4$

Tevens is in tabel 8.5.3 de invloed van de copingstijl "afwachten en vermijden" op de behoefte aan aanwezigheid van een intensive care medewerker tijdens het eerste bezoek aan de patiënt op de intensive care te zien $\left(\chi^{2}=9.12, \mathrm{df}=2, \mathrm{p}=.01\right)$. Familieleden, uit de totale onderzoeksgroep, met een hogere score (2.1) op de copingstijl "afwachten en vermijden" geven vaker de voorkeur aan de aanwezigheid van een andere discipline (type B) dan familieleden (type A en C) met een lagere score (1.8 en 1.7). De familieleden met een lagere score (1.8) geven meer de voorkeur aan de aanwezigheid van de verpleegkundige (type A). Type $\mathrm{C}$ (heeft geen behoefte aan de aanwezigheid van een intensive care medewerker tijdens het eerste bezoek aan de patiënt) heeft de laagste score op de copingstijl "afwachten en vermijden" (1.7).

\section{Palliatief gedrag}

"Palliatief gedrag" is van invloed op de behoefte aan aanwezigheid van een intensive care medewerker tijdens het eerste bezoek aan de patiënt in de totale onderzoeksgroep en in de groep familieleden van hartoperatiepatiënten.

In tabel 8.5.4 is te zien dat, in de totale onderzoeksgroep, familieleden met een hogere score (2.4) op de copingstijl "palliatief gedrag" duidelijk vaker $\left(\chi^{2}=6.59, \mathrm{df}=2, \mathrm{p}=.03\right)$ de aanwezigheid van een andere discipline wensen tijdens het eerste bezoek aan de patiënt op de intensive care (type B), dan familieleden met een lage score.

Type $\mathrm{A}$ en $\mathrm{C}$ familieleden (geven de voorkeur aan de verpleegkundige of wensen geen aanwezigheid van een intensive care medewerker tijdens het eerste bezoek aan de patiënt) hebben een relatief lage score op de copingstijl "palliatief gedrag" (2.2 en 2.1). 
Tabel 8.5.4 Invloed van de copingstijl "palliatief gedrag" op de behoefte van familieleden aan aanwezigheid van een intensive care medewerker tijdens het eerste bezoek aan de patiënt op de intensive care.

\begin{tabular}{|lllll|c|c|}
\hline & & & & & \\
\hline
\end{tabular}

Min. score $=1$

Max. score $=4$

In de groep familieleden van hartoperatiepatiënten worden dezelfde resultaten gevonden als in de totale onderzoeksgroep. Type $A$ en $C$ (wenst de aanwezigheid van een verpleegkundige tijdens het eerste bezoek aan de patiënt of vindt de aanwezigheid van een intensive care medewerker tijdens het eerste bezoek niet belangrijk) $\left(\chi^{2}=7.38, \mathrm{df}=2, \mathrm{p}=.02\right)$ hebben een lagere score op de copingstijl "palliatief gedrag" (2.3 en 2.0) dan type B (wenst de aanwezigheid van een andere discipline tijdens het eerste bezoek aan de patiënt op de intensive care. Type B heeft een gemiddelde score van 2.5 op de copingstijl "palliatief gedrag".

\subsection{Kenmerken van familieleden en typen familieleden}

In de volgende paragrafen worden, met behulp van aspectmetingen met de beïnvloedende variabelen voorspellingen gedaan, gericht op specifieke typen familieleden (familieleden die de voorkeur geven aan de verpleegkundigen, type $A$ en familieleden die aan een andere discipline de voorkeur geven, type B). Ondanks het gegeven dat het hier wederom slechts gaat om een globale benadering van de onafhankelijke variabelen en er geen dominante positie is toe te schrijven aan de op zich zelf staande variabelen in de regressie, is uit theoretische en praktische overwegingen gepoogd de typologie gericht op de rol van de verpleegkundige verder uit te werken.

In de eerste plaats is nogmaals gekeken naar de 7 behoefte-items die in de typologie zijn opgenomen (hoofdstuk 7). Vervolgens zijn de beïnvloedende variabelen per behoefte-item nader beschouwd en is in het bijzonder gekeken naar de invloed op het type familielid dat voorkeur heeft voor de verpleegkundige (type A) en het type familielid dat voorkeur heeft voor een andere discipline (type B).

Opvallend is dat slechts bij 1 van de 7 behoefte-items (onplezierige ervaring) een variabele opgenomen wordt in de regressie. Bij de andere behoefte-items wordt geen van de beïnvloedende variabelen opgenomen in de regressie analyses. 
Uit tabel 8.6 is af te leiden dat 1 van de 2 beïnvloedende variabelen is opgenomen in de regressie ( $\chi^{2}=6.44 ; \mathrm{df}=1 ; \mathrm{p}=.01$ ), te weten: "een onplezierige ervaring op de intensive care". Dit kenmerk kan gezien worden als de beste voorspeller als het gaat om de voorkeur van familieleden voor de verpleegkundige met betrekking tot ondersteuning op de intensive care.

Tabel 8.6 Logistische regressie-analyse voor de variabele "behoefte aan ondersteuning op de intensive care".

\begin{tabular}{|c|c|c|c|c|c|}
\hline 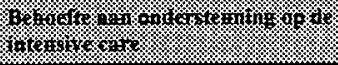 & \%. & $x$ & 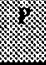 & 1 & 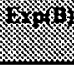 \\
\hline $\begin{array}{l}\text { Onplezierige ervaring } \\
\text { Constant }\end{array}$ & $\begin{array}{l}-1.41 \\
-.83\end{array}$ & $\begin{array}{l}.60 \\
.30\end{array}$ & $\begin{array}{l}.01 \\
.00\end{array}$ & -.18 & .24 \\
\hline
\end{tabular}

$\left(x^{2}=6.44 ; d f=1 ; p=.01\right)$

Uit tabel 8.6 is af te leiden dat het ontbreken van een onplezierige ervaring op de intensive care de beste voorspeller is als het gaat om de voorkeur van familieleden met betrekking tot ondersteuning door de verpleegkundige.

\subsection{Samenvatting}

In dit hoofdstuk is de invloed van sociaal-demografische-, intensive care gelieerde-, ziektegebonden- en copingvariabelen op typen familieleden beschreven. Zowel de relatie van het familielid met de patiënt, de leeftijd van het familielid als het woongebied van het familielid zijn van invloed op de typen familieleden. Van de intensive care gelieerde factoren spelen vooral de wachttijd op opname van de patiënt en een onplezierige ervaring van het familielid een beïnvloedende rol. Van de ziektegebonden variabelen zijn de opnamefrequentie van de patiënt, het feit of de patiënt mechanische beademd wordt en de planning van de opname van de patiënt (spoed of geen spoed) van invloed op de typologie van familieleden.

Bij de copingstijlen wordt een invloed van alle copingstijlen (4) gezien op de typologie van familieleden.

Als het gaat om de aanwezigheid van een intensive care medewerker tijdens het eerste bezoek aan de patiënt ligt de voorkeur bij de verpleegkundige. Ook de uitleg van de medische behandeling van de patiënt zien familieleden graag door de verpleegkundige gerealiseerd.

Bij de contactpersoon wordt de voorkeur aan een andere discipline gegeven. Familieleden op de intensive care worden bij voorkeur ondersteund door de verpleegkundige. Ook informatie over een eventuele overplaatsing van de patiënt naar een andere afdeling of ziekenhuis wensen familieleden van de verpleegkundige te krijgen. Wanneer het gaat om de uitleg van de apparatuur die bij de patiënt wordt gebruikt, wordt de voorkeur aan de verpleegkundige gegeven.

Opvallend is dat familieleden met een hogere score op de copingstijlen "actief aanpakken" en "sociale steun zoeken" over het algemeen de voorkeur geven aan de verpleegkundige.

Een hogere score op de copingstijl "afwachten en vermijden" leidt tot voorkeur voor een andere discipline. In sommige gevallen leiden deze copingstijlen bij familieleden tot de wens geen informatie of ondersteuning te ontvangen. 
Op de behoefte aan "het kunnen spreken over ervaringen en gevoelens op de intensive care" hebben de factoren zoals beschreven in dit hoofdstuk geen invloed. Mogelijk ligt hieraan het gebrek aan belangstelling van familieleden (135 van de 176 in de typologie opgenomen familieleden) voor deze behoefte ten grondslag.

Met behulp van logistische regressie analyses is gepoogd voorspellingen te doen gericht op de voorkeur van familieleden voor de verpleegkundige. Bij de behoefte van familieleden aan ondersteuning op de intensive care is een onplezierige ervaring de beste voorspeller. 



\section{ZORG VOOR FAMILIELEDEN IN DE PRAKTIJK}

\subsection{Inleiding}

In dit hoofdstuk wordt ingegaan op de praktische relevantie en consequenties van de resultaten uit deze studie voor de verpleegkundige beroepspraktijk op de intensive care. Eerst wordt ingegaan op behoeften van familieleden, waarbij op behoefte-item niveau de resultaten vergeleken worden met resultaten uit andere studies. Vervolgens wordt, met behulp van de resultaten uit de hoofdstukken 5,6,7 en 8 , ingegaan op de mogelijkheden voor verpleegkundige interventies gericht op familieleden op de intensive care. Met behulp van de in hoofdstuk 7 en 8 ontwikkelde typologie voor familieleden van intensive care patiënten, wordt ingegaan op de specifieke behoeften van familieleden, de beïnvloedende factoren en de verpleegkundige interventies die noodzakelijk zijn om de zorg voor familieleden op de intensive care te realiseren door invoering van een systeem van zorg voor familieleden.

\subsection{Behoeften van familieleden op de intensive care, een vergelijking}

Om de consequenties van de resultaten uit deze studie voor de praktijk verder te onderbouwen en in breder perspectief te beschouwen, zijn de resultaten met andere studies vergeleken. Hierbij is met name gekeken naar overeenkomstig gemeten behoefte-items.

Tabel 9.2 toont een vergelijking van de resultaten van zes studies in de periode van 1979 tot 1997, waarbij vijf behoefte-items door alle onderzoekers gemeten zijn met behulp van de Critical Care Family Needs Inventory (Molter, 1979).

Tabel 9.2 Overzicht meanscores behoefte-items

\begin{tabular}{|c|c|c|c|c|c|c|}
\hline 3\%" & \% & 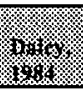 & 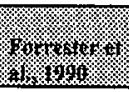 & ${ }_{1}{ }^{4}$ & 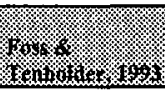 & (x \\
\hline $\begin{array}{l}\text { Op de hoogte gesteld } \\
\text { worden van overplaat- } \\
\text { sing van de patiènt }\end{array}$ & 3.1 & 3.4 & 3.5 & 3.4 & 3.6 & 3.4 \\
\hline $\begin{array}{l}\text { Uitleg over de medi- } \\
\text { sche behandeling }\end{array}$ & 3.2 & 3.8 & 3.8 & 3.8 & 3.2 & 3.2 \\
\hline $\begin{array}{l}\text { Op ieder moment op } \\
\text { bezoek kunnen }\end{array}$ & 2.9 & 3.0 & 3.6 & 3.0 & 3.5 & 3.0 \\
\hline $\begin{array}{l}\text { Ervaringen kunnen } \\
\text { bespreken }\end{array}$ & 1.1 & 2.8 & 3.2 & 2.6 & 3.2 & 2.1 \\
\hline $\begin{array}{l}\text { Het gevoel hebben niet } \\
\text { in de weg te lopen }\end{array}$ & 3.4 & 3.0 & 3.5 & 3.1 & 3.6 & 3.3 \\
\hline
\end{tabular}

Min. score $=I$ (onbelangrijk)

Max. score $=4$ (zeer belangrijk)

Om een uitspraak te kunnen doen over het belang van de behoefte-items is een rangorde toegepast per onderzoeker, waarbij 1 de hoogste score op het behoefte-item en 5 de laagste score op het behoefte-item weergeeft. 
Vervolgens is het aantal punten van alle onderzoekers per behoefte-item opgeteld en wordt het totaal aantal punten in de laatste kolom weergegeven (tabel 9.2.1).

Tabel 9.2.1 Overzicht scores behoefte-items

\begin{tabular}{|c|c|c|c|c|c|c|c|}
\hline 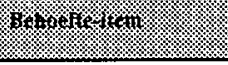 & \%orit & 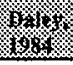 & 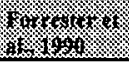 & 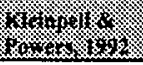 & 6) & (x) & 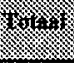 \\
\hline $\begin{array}{l}\text { Op de hoogte gesteld } \\
\text { worden van overplaat- } \\
\text { sing van de patiênt }\end{array}$ & 3 & 2 & 3.5 & 2 & 1.5 & 1 & 13 \\
\hline $\begin{array}{l}\text { Uitleg over de medi- } \\
\text { sche behandeling }\end{array}$ & 2 & 1 & 1 & .1 & 4.5 & 3 & 12.5 \\
\hline $\begin{array}{l}\text { Op ieder moment op } \\
\text { bezoek kunnen }\end{array}$ & 4 & 3.5 & 2 & 4 & 3 & 4 & 20.5 \\
\hline $\begin{array}{l}\text { Ervaringen kunnen } \\
\text { bespreken }\end{array}$ & 5 & 5 & 5 & 5 & 4.5 & 5 & 29.5 \\
\hline $\begin{array}{l}\text { Het gevoel hebben niet } \\
\text { in de weg te lopen }\end{array}$ & 1 & 3.5 & 3.5 & 3 & 1.5 & 2 & 14.5 \\
\hline Totaal & 15 & 15 & 15 & 15 & 15 & 15 & 90 \\
\hline
\end{tabular}

$\chi^{2}=16.97, d f=4, p=<.01$

In tabel 9.2.1 is te zien dat het hoogst aantal punten en dus de laagste waarde, toegekend is (29.5) aan de behoefte om te kunnen spreken over ervaringen en gevoelens op de intensive care. Na uitvoering van een Chi-kwadraat-analyse voor zes onderzoeken, blijkt dat de behoefte van familieleden om te kunnen spreken over ervaringen en gevoelens op de intensive care significant lager scoort $\left(\chi^{2}=16.97, \mathrm{df}=4, \mathrm{p}=<.01\right)$ in alle, in tabel 9.2.1 opgenomen onderzoeken, dan de andere behoefte-items.

Op grond van bovenstaande vergelijking kan geconcludeerd worden dat familieleden van intensive care patiënten, in volgorde van belang, behoefte hebben aan (1) uitleg over de medische behandeling van de patiënt, (2) informatie over de overplaatsing van de patiënt, (3) het gevoel om niet in de weg te lopen op de intensive care, (4) op ieder moment de patiënt te kunnen bezoeken en (5) het kunnen bespreken van ervaringen en gevoelens op de intensive care. Hierdoor is een behoefte hiërarchie ontstaan, welke is gebaseerd op zes studies, waaronder deze studie, die in de afgelopen 18 jaar hebben plaatsgevonden.

Wanneer bovengenoemde resultaten beschouwd worden in het licht van de resultaten van de zes (tabel 9.2.1) eerder genoemde studies, valt op, dat drie van de zeven behoefte-items uit dit onderzoek (tabel 9.3.1) overeenkomen met de vijf generale behoefte-items. Met name de twee hoogst gescoorde behoefte-items (uitleg over de medische behandeling en informatie over een eventuele overplaatsing van de patiënt) en het laagst gescoorde behoefte-item (om te kunnen spreken over ervaringen en gevoelens) komen overeen met eerder genoemde studies. 
In tabel 9.2.2 wordt het resultaat van de vijf behoefte-items per onderzoeker gepresenteerd. Om hierover een uitspraak te kunnen doen is een rangorde toegepast per behoefte-item, waarbij 1 de hoogste score per onderzoeker en 6 de laagste score per onderzoeker weergeeft. Vervolgens is het aantal punten van alle behoefte-items per onderzoeker opgeteld en wordt het totaal aantal punten op de laatste rij weergegeven.

Tabel 9.2.2 Overzicht scores onderzoekers

\begin{tabular}{|c|c|c|c|c|c|c|c|}
\hline 3. & Witra & 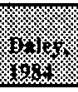 & (x) & (1) & (4) & 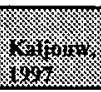 & 4 \\
\hline $\begin{array}{l}\text { Op de hoogte gesteld } \\
\text { worden van overplaat- } \\
\text { sing van de patient }\end{array}$ & 6 & 4 & 2 & 4 & 1 & 4 & 21 \\
\hline $\begin{array}{l}\text { Uitleg over de medi- } \\
\text { sche behandeling }\end{array}$ & 5 & 2 & 2 & 2 & 5 & 5 & 21 \\
\hline $\begin{array}{l}\text { Op ieder moment op } \\
\text { bezoek kunnen }\end{array}$ & 6 & 4 & 1 & 4 & 2 & 4 & 21 \\
\hline $\begin{array}{l}\text { Ervaringen kunnen } \\
\text { bespreken }\end{array}$ & 6 & 3 & 1,5 & 4 & 1.5 & 5 & 21 \\
\hline $\begin{array}{l}\text { Het gevoel hebben niet } \\
\text { in de weg te lopen }\end{array}$ & 3 & 6 & 2 & 5 & 1 & 4 & 21 \\
\hline Totaal & 26 & 19 & 8.5 & 19 & 10.5 & 22 & 105 \\
\hline
\end{tabular}

In tabel 9.2.2 is te zien dat het laagst aantal punten, en dus de hoogste waarden, gescoord is door Forrester et al., (1990) en Foss \& Tenholder, (1993). Hieruit kan worden afgeleid dat deze onderzoekers de hoogste scores vonden op de vijf behoefte-items. De laagste scores zijn gevonden door Molter, (1979). Vergeleken met andere studies zijn in deze studie relatief lage scores gevonden (22) op de vijf behoefte-items. Om een uitspraak te kunnen doen over de resultaten van onderhavige studie in het licht van de resultaten uit de andere studies, is een Chi-kwadraat-analyse uitgevoerd. Hieruit kan afgeleid worden dat de scores in de studies van van Forrester et al., (1990) en Foss \& Tenholder, (1993) significant lager zijn $\left(\chi^{2}=14.3, \mathrm{df}=5\right.$, $\mathrm{p}=<.02$ ) dan de scores in de studies van Molter, (1979; Daley, (1984); Kleinpell \& Powers, (1992) en Kaljouw, (1997). Er lijkt een onderliggende behoeftestructuur te bestaan die overeenkomsten vertoont tussen de resultaten uit de Verenigde Staten Molter, (1979); Daley, (1984) en Kleinpell \& Powers, (1992) en onderhavige studie. Hierbij dient echter te worden opgemerkt dat het slechts gaat om enkele studies en een klein aantal behoefte-items.

\subsection{De beroepspraktijk op de intensive care}

Uit onderhavige studie blijkt, dat regelmatig niet in de behoeften van familieleden op de intensive care wordt voorzien (hoofdstuk 7). Uitzondering is de behoefte aan aanwezigheid van een verpleegkundige tijdens het eerste bezoek aan de patiënt. Tabel 9.3 geeft een overzicht van behoefte-items en de percentages waarin niet in de behoeften is voorzien. 
Tabel 9.3 Overzicht en percentages van behoeften waarin niet is voorzien (\%).

\begin{tabular}{|l|l|}
\hline Uitleg over de medische behandeling & 41 \\
Aanwezigheid van een intensive care medewerker tijdens het \\
eerste bezoek aan de patient \\
Aanwezigheid van een contactpersoon & 8.5 \\
Informatie over een eventuele overplaatsing van de patient & 44 \\
Ondersteuning van een intensive care medewerker & 33 \\
Uitleg over de apparatuur & 23 \\
Kunnen spreken over ervaringen en gevoelens & 45.5 \\
\hline
\end{tabular}

Een verklaring voor deze resultaten kan gezocht worden in het feit dat verpleegkundigen en andere hulpverleners op de intensive care, bij opname van een patient op de intensive care, de aandacht direct vestigen op de patiënt, immers deze verkeert in een levensbedreigende situatie. Hierdoor ontstaat de neiging van familieleden om zichzelf volledig weg te cijferen ten behoeve van een maximale behandeling van de patiënt (Daley, 1984). Ook is het meestal zo dat, wanneer familieleden door de verpleegkundige geïnformeerd worden, de besproken problemen door de verpleegkundige als probleem worden ervaren en niet door de familieleden (Daley, 1984). Hierdoor ontstaat intuïtief handelen op basis van persoonlijke inschatting.

Zoals eerder in dit proefschrift beschreven (hoofdstuk 2) speelt ook het copinggedrag van familieleden een rol. Familieleden verkeren in een stressvolle situatie waarbij gevoelens van angst en onzekerheid een rol spelen. Hierdoor kan het zo zijn dat familieleden slechts in staat zijn om selectief te luisteren, waardoor sommige informatie wel overkomt en andere niet. Copinggedrag van familieleden, bijvoorbeeld stressreductie door vermijdingsgedrag (Janssen $e t$ al., in voorbereiding), kan direct leiden tot het gevoel van familieleden onvoldoende of geen informatie te krijgen.

Tevens is het zo dat geëigend vakjargon dat veelvuldig gebruikt wordt door intensive care medewerkers vaak onbegrijpelijk overkomt bij familieleden. Wanneer familieleden vervolgens niet in staat zijn of durven om verduidelijking en uitleg te vragen, zullen zij opnieuw het gevoel hebben onvoldoende of geen informatie te krijgen.

Tot slot is het zo dat familiebegeleiding vaak naar de achtergrond verdwijnt, ondanks goede bedoelingen van intensive care medewerkers (Daley, 1984). De prioriteit ligt bij de patiënt zodat wensen van familieleden gemakkelijk vergeten of genegeerd worden (Daley, 1984).

\subsection{De rol van de verpleegkundige}

Familieleden van intensive care patiënten werpen, als het gaat om behoeften op de intensive care, de handschoen wel gericht naar de verpleegkundige. Niet alleen bevindingen uit de literatuur (hoofdstuk 2), maar vooral ook familieleden zelf steunen het belang van behoeften op de intensive care en de rol die de verpleegkundigen hierin zouden kunnen spelen. 
Het gegeven dat regelmatig niet in behoeften van familieleden wordt voorzien doet afbreuk aan het professioneel handelen op de intensive care. Wanneer deze situatie niet verbeterd wordt, kan een bedreiging ontstaan voor de (verpleegkundige) beroepspraktijk. Verpleegkundigen zouden in staat moeten zijn om deze bedreiging tot een kans om te buigen. Op deze wijze ontstaat de uitdaging om het verpleegkundig domein uit te breiden met "op maat gesneden" zorg voor familieleden.

Naast de uitdaging is het belang van adequate zorg voor familieleden groot. Familieleden hebben, evenals patiënten, recht op informatie en een correcte bejegening. De Wet op de Geneeskundige Behandelings Overeenkomst (WGBO, 1995) schrijft de arts voor, de patiënt te informeren en hem toestemming te verlenen tot behandeling. Wanneer de patiënt niet in staat is om toestemming te verlenen, wat op de intensive care vaak het geval is, treedt de naaste familie op voor de patiënt.

De Kwaliteitswet Zorginstellingen (1996) dwingt zorginstellingen verantwoording af te leggen over de geleverde kwaliteit van zorg. Deze zorg strekt verder dan alleen de patiënt en richt zich ook op diens omgeving, waartoe familieleden gerekend mogen worden.

Voor de verpleegkundigen is vooral de wet op de Beroepen in de Individuele Gezondheidszorg (BIG, Sindram,1993) van belang. Niet alleen de patiënt, maar ook diens familie kan een klacht indienen bij het verpleegkundig tuchtcollege (december,1997) wanneer hij van mening is dat hem onrecht wordt aangedaan.

\subsubsection{Verpleegkundige interventies}

Om een uitspraak te doen over de verpleegkundige interventies bij behoeften van familieleden is gebruik gemaakt van de resultaten uit hoofdstuk 6 en 7.

Hierin worden niet alleen de beïnvloedende factoren beschreven, maar vooral ook welke behoeften familieleden belangrijk vinden en wie in deze behoeften zou moeten voorzien.

Behoeften van familieleden worden beïnvloed door verschillende factoren (hoofdstuk 6 , figuur 6.7). Het gaat hier om zowel sociaal-demografische-, intensive care gelieerde-, ziektegebonden- en coping factoren. Verpleegkundigen dienen zich hiervan bewust te worden, met andere woorden: verpleegkundigen moeten familieleden leren zien als mensen met individuele wensen en niet als een groep zorgvragers met een collectieve hulpvraag. Deze benadering vergt een professionele houding van verpleegkundigen en een attitude waaruit betrokkenheid en verantwoordelijkheid blijkt. Om verpleegkundige interventies, gericht op familieleden, op een professionele wijze uit te voeren zal de verpleegkundige moeten beschikken over een theoretisch kader van waaruit het handelen gestalte krijgt. Verpleegkundigen moeten zicht hebben op de situatie waarin familieleden verkeren. Tevens dienen zij in staat te zijn om, met behulp van beïnvloedende factoren, de hulpvraag van familieleden te analyseren en te toetsen. Op deze wijze neemt professionele zorg voor familieleden de plaats in van intuïtief handelen op basis van persoonlijke (verpleegkundige) inschatting. 
Gezien de feitelijke rol van verpleegkundigen in het verstrekken van informatie aan familieleden is het van belang dat artsen en verpleegkundigen samen werken als het gaat om het analyseren van de hulpvraag en het toetsen van de resultaten. Essentieel hierbij is dat informatie in de juiste context en op een begrijpelijke wijze wordt verstrekt.

\subsection{De organisatie}

Om adequaát en professioneel in te kunnen gaan op behoeften van familieleden is het noodzakelijk eerst voorwaarden te creëren alvorens verpleegkundige interventies te formuleren en uit te voeren. "Wanneer zorg voor familieleden gezien wordt als een activiteit die verricht wordt door zelfstandige beroepsbeoefenaren zal men eigenstandig de zorgproblemen waarop men intervenieert moeten kunnen benoemen. Dit impliceert dat er een systeem van zorgproblemen moet zijn of dat er steeds met eigen woorden een probleem benoemd wordt. Het zal duidelijk zijn dat het steeds met eigen woorden benoemen niet erg efficiënt is. Al doet het misschien het meest recht aan de individuele zorgsituatie, het is weinig richtinggevend voor interventies" (Frederiks, 1997). De intensive care organisatie en haar medewerkers zullen moeten veranderen om de zorg voor familieleden te legitimeren en in te voeren binnen het verpleegkundig domein. Hiernaast zal afstemming plaats moeten vinden tussen de diverse disciplines die betrokken worden bij de zorg voor familieleden.

Tot slot zal een model gekozen moeten worden, passend binnen het bestaande verpleegkundig zorgproces, om de continuilteit van zorg voor familieleden te garanderen. Hierop zal later in dit hoofdstuk worden ingegaan.

Om de zorg voor familieleden in de praktijk te realiseren, is het van belang om deze zorg een duidelijke plaats te geven in het totale zorgproces. Na de opname van de patiënt op de intensive care zou direct, of direct daarna, een intake-gesprek met de familie gevoerd kunnen worden. Met behulp van de familiegegevens kan de zorg voor de familię gepland, uitgevoerd en getoetst worden. Deze situatie vereist van verpleegkundigen een professionele houding. Niet alleen dienen zij kennis te hebben van de professionele standaard en het verpleegkundig domein, tevens dienen zij over kennis van intensive care te beschikken en inzicht te hebben in de ingewikkelde (medische) processen die zich bij intensive care patiënten voordoen.

Verpleegkundigen zullen voldoende geëquipeerd moeten zijn om de zorg op de intensive care te structureren, uit te voeren en te coördineren. Hiervoor zullen verpleegkundigen regelmatig moeten worden (bij)geschoold en vakliteratuur moeten bijhouden.

Verpleegkundigen zouden meer betrokken moeten raken bij het totale "product".

In onderhavig geval betreft het zorg voor mensen hetgeen een service- en klantgerichte instelling vergt. Verpleegkundigen dienen hiervoor de handen ineen te slaan en samen te werken. $\mathrm{Zij}$ zullen een structurele vorm van interdisciplinaire toetsing in moeten voeren en een kritische houding aan moeten nemen om de toets der kritiek te kunnen doorstaan.

Dit laatste vergt niet alleen inspanningen van de individuele verpleegkundige, maar ook van het management van de intensive care organisatie. Waar mensen (verpleegkundigen) werken voor mensen (familie-leden) zal geïnvesteerd moeten worden in beide partijen. Hierbij kan gedacht worden aan team building en coaching. 


\subsection{Het systeem van zorg voor familieleden}

Nadat de patiënt is opgenomen op de intensive care zullen verpleegkundigen de gelegenheid moeten nemen en krijgen om familieleden te woord te staan. Naast informatie over de situatie waarin de patiënt verkeert, zal de verpleegkundige de zorgvraag en specifieke behoeftepatronen van de familie moeten analyseren. Hierna kan, indien gewenst en noodzakelijk, naast het behandelplan voor de patiënt, een familie-zorgplan worden opgesteld waarin afspraken gemaakt worden met betrekking tot specifieke wensen. Hierbij speelt de flexibiliteit van de organisatie en de verpleegkundige een grote rol. Wanneer familieleden bijvoorbeeld een bijzondere bezoekregeling wensen, kan de situatie ontstaan dat organisatiebelangen en belangen van de verpleegkundige onder druk komen te staan. Juist deze belangen pleiten voor de ontwikkeling van een familie-zorgplan waarin belangen van organisatie, verpleegkundigen en familieleden op elkaar worden afgestemd. Niet altijd zal een familie-zorgplan noodzakelijk zijn. Belangrijk is dat verpleegkundigen familieleden tevens leren zien als consument, waarbij een klant-leverancier relatie tot de mogelijkheden gaat behoren. Het familie-zorgplan dient als zodanig op basis van individuele noodzaak te worden ingevoerd en niet in de rij protocollen te belanden.

Bij de ontwikkeling van een familie-zorgplan dienen, naast afstemming van de organisatie, ook de belangen van disciplines die betrokken zijn bij de zorg rondom de patiënt, op elkaar te worden afgestemd. In samenspraak met de behandeld arts zal de verpleegkundige afspraken moeten maken over de interventies die gericht zijn op familieleden. Hierbij moet gedacht worden over taakverdeling met betrekking tot informatieverstrekking. Hierbij gaat het er niet alleen om wie de informatie geeft, maar vooral ook dat deze wordt gegeven en dat de informatie in begrijpelijke taal wordt gegeven. Ook zouden verpleegkundigen niet moeten schromen om informatie te verstrekken op het gebied van de medische behandeling. Niet alleen geven veel familieleden hieraan de voorkeur, ook is het zo dat verpleegkundigen hiervan vaak goed op de hoogte - en beter in staat zijn om informatie in begrijpelijke taal te communiceren.

Het familie-zorgplan zal moeten worden afgestemd op het vigerende totale zorgbeleid van de intensive care. Dit impliceert familiezorg beleid dat geïntegreerd wordt binnen het totale zorgbeleid. Familiezorg gaat op deze wijze deel uit maken van het algemeen zorgbeleid binnen de organisatie. Tevens is voor familieleden continuïteit van zorg van belang. Wanneer de patiënt wordt overgeplaatst naar een andere afdeling of instelling, is het van belang dat niet alleen de gegevens van de patiënt worden overgedragen, maar ook de gegevens van de familie.

Familiezorg eindigt, evenals als patiëntenzorg, niet bij overplaatsing, maar is een doorlopend proces dat gevolgd moet worden tot het moment dat familieleden zelf in staat zijn om in hun behoeften te voorzien.

\subsubsection{De familie-anamnese}

Om de zorg voor familieleden op een adequate wijze te kunnen uitvoeren dient de familieanamnese gezien te worden als de basis voor het zorgplan. Om continuiteit en uniformiteit te waarborgen verdient het schriftelijk vastleggen van gegevens de voorkeur. Hierbij moet worden opgemerkt dat het anamneseformulier slechts een middel is en geen doel op zich. De informatie die door familieleden gegeven wordt vormt het uitgangspunt voor verder beleid. 
Familieleden bepalen zelf of begeleiding door verpleegkundigen wel, dan niet, geïndiceerd is. Het is dan ook van groot belang dat informatie van familieleden volledig is en/of zonodig kan worden gewijzigd of uitgebreid. Toch is het zo dat de resultaten uit dit onderzoek als leidraad kunnen dienen voor een familie-anamnese. Hierbij zou dan met name gedacht kunnen worden aan praktisch relevante beïnvloedende factoren zoals sociaal-demografische-, intensive care gelieerde- en ziektegebonden factoren. Deze factoren zouden structureel meegenomen kunnen worden tijdens het voeren van het anamnesegesprek. Wanneer verpleegkundigen op de hoogte zijn van de invloed van deze factoren kunnen meer gerichte vragen gesteld worden. Aan te bevelen is om praktisch relevante factoren reeds te benoemen in het anamneseformulier (zie figuur 9.6.1).

Figuur 9.6.1 Voorbeeld familie-anamnese formulier

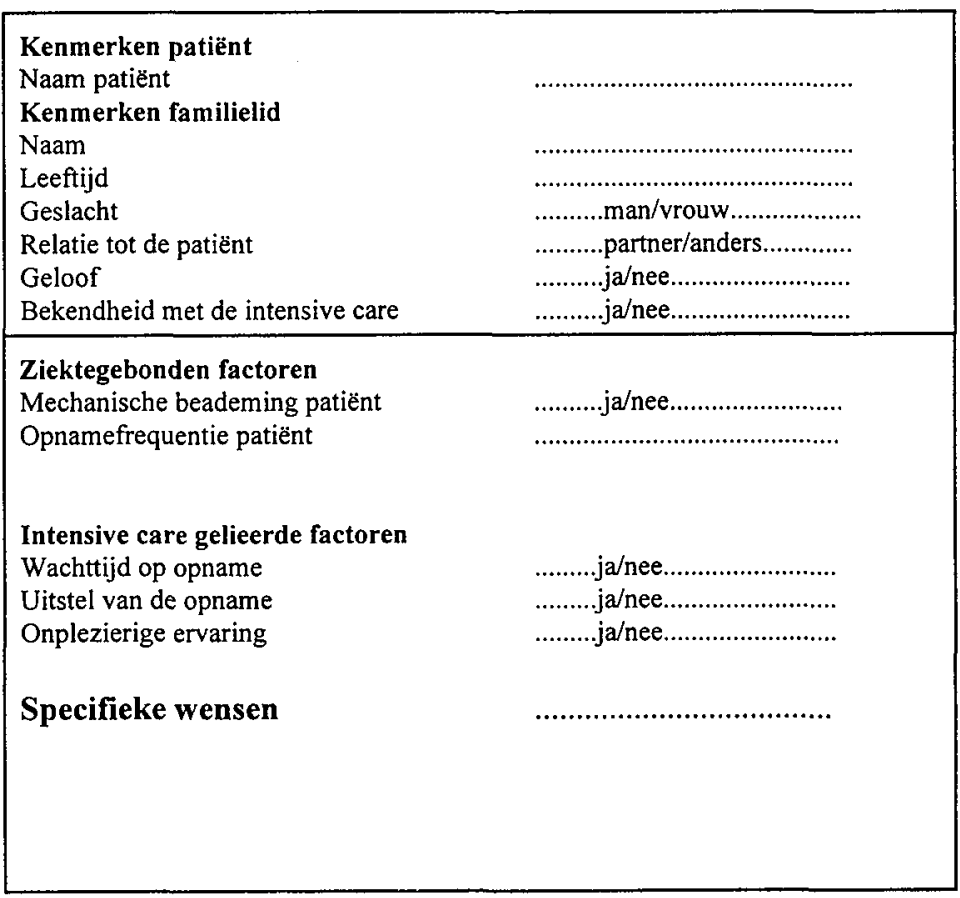

\subsubsection{Werkwijze}

Voor de verpleegkundige beroepspraktijk is het van belang stil te staan bij het tijdstip en de wijze waarop de familie-anamnese op de intensive care wordt afgenomen. Het behoeft geen betoog dat de opname van de patiënt op de intensive care prioriteit heeft, immers deze verkeert in een levensbedreigende situatie. Toch is het zo dat het één het ander niet behoeft uit te sluiten. Aan de hand van de hierna volgende casuïstiek worden mogelijke verpleegkundige interventies besproken. 


\section{Casuïstiek}

Door de G.G.\&G.D. wordt de opname van een trauma patiènt op de intensive care aangekondigd binnen 15 minuten. De patiènt wordt eerst aangeboden op de afdeling Spoed-Eisende Hulp alwaar de behandeling wordt ingezet. Inmiddels wordt de familie gewaarschuwd en verzocht naar het ziekenhuis te komen. Hier ontstaat de eerste verpleegkundige interventie. Afgesproken moet worden wie de familie opvangt en welke informatie gegeven kan worden (waar de patiënt wordt opgenomen, wat er aan de hand is, wanneer men de patiënt kan zien en wat men kan verwachten).

De patiënt wordt vervolgens naar de intensive care gebracht, aangesloten aan de vereiste apparatuur en geïnstalleerd. Deze handelingen vereisen menskracht en tijd, echter wanneer familieleden hiervan op de hoogte zijn gesteld zullen zij veelal bereid zijn te wachten tot zij kunnen worden toegelaten tot de intensive care. Hier ontstaat een tweede verpleegkundige interventie. Van belang is dat iemand de familie begeleid naar de patiënt en uitleg geeft over de aanblik van de patiënt. Wanneer familieleden de patiënt hebben kunnen zien en er uitleg gegeven is over de situatie, zou een afspraak gemaakt kunnen worden om rustig te praten over specifieke wensen en verwachtingen van familieleden, een derde interventie.

Het tijdstip tussen rustig praten met familieleden en opname van de patiënt op de intensive care kan op deze wijze aanmerkelijk uit elkaar liggen zonder dat familieleden tekort wordt gedaan. Intensive care verpleegkundigen worden zo in staat gesteld prioriteiten te stellen en werkzaamheden te plannen. Pas op het moment dat rustig gesproken kan worden met familieleden is het aan te bevelen daadwerkelijk te starten met een familie-anamnese, een vierde interventie.

De patiënt is inmiddels opgenomen op de intensive care en aangesloten aan de apparatuur. De familie heeft de patiënt even gezien en weet hoe de situatie er in grote lijnen uitziet. Van hen wordt verwacht dat ze afwachten tot de verpleegkundige bij ze komt voor een gesprek. Wanneer familieleden de weg weten en gewezen zijn op eventuele (restauratieve) voorzieningen zullen zij overwegend geen bezwaar tonen tegen een wachttijd. Uiteraard dient voor de wachttijd een indicatie gesteld te worden.

Voor het gesprek met familieleden is het van belang dat verpleegkundigen de tijd nemen. Zij moeten goed kunnen luisteren en inschatten welke behoeften familieleden belangrijk vinden en op welke behoeften familieleden geen prijs stellen. Van belang is het stellen van de juiste vragen op het juiste tijdstip (antwoorden die kunnen worden afgeleid van patiëntengegevens kunnen wachten en wanneer familieleden compleet ontredderd zijn, dienen eerst vragen naar de reden van ontreddering gesteld te worden teneinde deze zo mogelijk te reduceren). Belangrijk is dat verwachtingen en specifieke wensen van familieleden gedocumenteerd worden (familie-anamnese).
Afhankelijk van de anamnese-gegevens kan besloten worden tot het gebruik van een zorgplan voor familieleden. Samen met familieleden kunnen afspraken worden gemaakt en gedocumen- teerd, een vijfde verpleegkundige interventie. Niet alleen is dit voor de verpleegkundige een professionele manier om zorg voor familieleden uit te voeren, te toetsen en over te dragen, ook voor familieleden is het prettig de afspraken na te kunnen lezen en eventueel uit te breiden, te reduceren en/of te wijzigen.

Op deze werkwijze kan het spanningsveld tussen prioriteit van handelen, werkdruk en zorg voor familieleden op de intensive care verkleind worden en gaat de zorg voor familieleden op de intensive care structureel deel uit maken van het totale zorgpakket op de intensive care. 


\title{
9.6.2 Het zorgplan voor familieleden
}

Zoals al eerder gezegd vormen de anamnesegegevens de basis voor het zorgplan. In dit plan worden afspraken vastgelegd en verpleegkundige interventies geformuleerd, gericht op behoeften van familieleden. Ook met betrekking tot het familie-zorgplan kunnen resultaten uit onderhavige studie een belangrijke rol spelen. Behoeften van familieleden kunnen categorisch worden onderscheiden in behoeften aan informatie, ondersteuning en toegankelijkheid. Met behulp van deze categorieën kunnen gerichte afspraken worden gemaakt met familieleden. Hierbij dienen de specifieke kenmerken van de organisatie, de patiënt en de familieleden, welke in het anamnesegesprek zijn vastgelegd, betrokken te worden. Op deze wijze kunnen op een vrij eenvoudige manier (figuur 9.6.2) behoeften van familieleden worden gedocumenteerd, gepland, uitgevoerd en getoetst. Ook kan op deze wijze de overdracht van gegevens plaatsvinden.

Tabel 9.6.2 Voorbeeld familie-zorgplan

\section{Familie-zorgplan}

\author{
Persoonlijke gegevens familielid \\ Naam
}

\begin{tabular}{|c|c|c|c|c|c|}
\hline $\begin{array}{l}\text { Hoofdbehandelaar } \\
\text { Verpleegkundige }\end{array}$ & 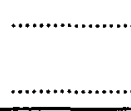 & $\ldots$ & . & & \\
\hline 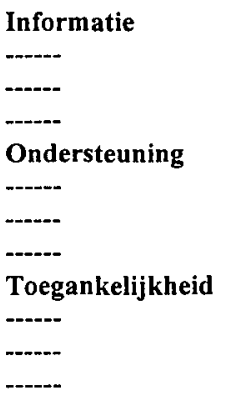 & $\begin{array}{l}\text { Belangrijk } \\
\text { Belangrijk } \\
\text { Belangrijk } \\
\text { Belangrijk } \\
\text { Belangrijk } \\
\text { Belangrijk } \\
\\
\text { Belangrijk } \\
\text { Belangrijk } \\
\text { Belangrijk }\end{array}$ & $\begin{array}{l}\square \\
\square \\
\square\end{array}$ & $\begin{array}{l}\text { Niet wenselijk } \\
\text { Niet wenselijk } \square \\
\text { Niet wenselijk } \square \\
\text { Niet wenselijk } \square \\
\text { Niet wenselijk } \square \\
\text { Niet wenselijk } \square \\
\text { Niet wenselijk } \square \\
\text { Niet wenselijk } \square \\
\text { Niet wenselijk } \square\end{array}$ & $\begin{array}{l}\text { Uitgevoerd } \\
\text { ja } \square \text { nee } \square \\
\text { ja } \square \text { nee } \square \\
\text { ja } \square \text { nee } \square \\
\text { ja } \square \text { nee } \square \\
\text { ja } \square \text { nee } \square \\
\text { ja } \square \text { nee } \square \\
\text { ja } \\
\text { ja } \\
\text { ja } \square \text { nee } \square \\
\square \text { nee } \square\end{array}$ & Behoefteverstrekker \\
\hline
\end{tabular}

\subsection{Samenvatting}

In dit hoofdstuk is een aanzet gegeven voor familiezorgbeleid op de intensive care.

Door middel van familie-anamnese gegevens, die de basis vormen voor een familie-zorgplan, kunnen praktisch relevante kenmerken van de patiënt, de organisatie en familie worden gedocumenteerd. Hierbij vormen de resultaten uit onderhavige studie de leidraad. 
Deze resultaten worden gesteund door bevindingen uit vijf studies in een periode van 18 jaar welke (gedeeltelijk) overeenkomen met de bevindingen uit deze studie. In het familiezorgplan kunnen afspraken worden vastgelegd en verpleegkundige interventies geformuleerd, gericht op behoeften van familieleden. Hiervoor zullen de intensive care organisatie en haar medewerkers moeten veranderen. Zowel van de organisatie als van haar medewerkers wordt een professionele attitude en een service gerichte instelling vereist om daadwerkelijk in behoeften van familieleden te kunnen voorzien. 



\section{NABESCHOUWING}

\subsection{Inleiding}

In dit laatste hoofdstuk vindt een terugkoppeling plaats naar de in deze studie gestelde onderzoeksvragen en wordt nagegaan in hoeverre deze onderzoeksvragen beantwoord worden. Achtereenvolgens worden de volgende onderwerpen behandeld: theoretische implicaties, resultaten, determinanten en effecten, de praktische implicaties en aanbevelingen voor verder onderzoek.

\subsection{Theoretische implicaties}

Tot dusver heeft in de studies naar behoeften van familieleden een theoretische onderbouwing ontbroken. Op grond van een aantal eerder genoemde overwegingen (hoofdstuk 2) is gekozen voor het Neuman Systems Model (Neuman, 1995). De theoretische relevantie van het onderzoek heeft dan ook betrekking op het nagaan van de bruikbaarheid van het Neuman Systems Model (Neuman,1995) ter beschrijving van primaire-, secundaire- en tertiaire verpleegkundige interventies ten behoeve van begeleiding van familieleden op de intensive care.

Met behulp van empirische materiaal uit eerdere studies (Molter, 1979; Daley, 1984; Leske, 1988) is een theoretische benadering ontwikkeld waarmee behoeften van familieleden op de intensive care kunnen worden ingebed in een theoretisch model. Hierbij is uitgegaan van het Neuman Systems Model (1995).

Daarna (hoofdstuk 3) is een modificatie in het model aangebracht gericht op secundaire verpleegkundige interventies, waarbij met name de drie behoeftecategorieën die in deze studie gemeten zijn, benoemd worden. In deze herformulering van het Neuman Systems Model (1995) zijn drie begrippen toegevoegd (behoefte aan informatie, ondersteuning en toegankelijkheid). In deze begrippen kunnen de behoefte-items zoals genoemd in het Neuman Systems Model (1995) worden opgenomen. Door middel van onderhavige studie is het gelukt om behoeften van familieleden van intensive care patiënten in kaart te brengen en aannemelijk te maken dat de drie behoeftecategorieën vruchtbaar gebruikt kunnen worden. In dit onderzoek wordt voornamelijk uitgegaan van behoeftecategorieën. De keuze voor categorieën is gebaseerd op bevindingen uit empirisch materiaal (Daley, 1984 en Leske, 1988).

Begripsmatig is bij de ontwikkeling van de behoeftecategorieën een onderscheid gemaakt tussen instrumenteel gerichte behoeften, sociaal emotioneel gerichte behoeften en op structuur gerichte behoeften. Oorspronkelijk waren ook op communicatie gerichte behoeften als categorie aangemerkt.

Factoranalyse van de resultaten leidt het meest vruchtbaar tot een categorische driedeling van behoeften van familieleden. De behoeften van familieleden zijn onder te brengen in drie behoeftecategorieën, te weten (1) behoeften aan informatie, (2) behoeften aan ondersteuning en (3) behoeften aan toegankelijkheid. 
De afzonderlijke behoeften aan communicatie spreiden zich over de andere categorieën. Communicatie is kennelijk een aspect van de behoeften aan (1) informatie, (2) ondersteuning en (3) toegankelijkheid. Op basis van de interne consistentie van de gehele behoeftelijst kunnen informatie, ondersteuning en toegankelijkheid gezamenlijk gezien worden als dimensies van een meer abstracte behoefte aan begeleiding.

\subsection{Resultaten}

Ter beschouwing van de resultaten worden achtereenvolgens de onderzoekspopulaties, determinanten en effecten en eigenschappen van de onderzoekspopulaties beschreven.

\subsubsection{Onderzoekspopulaties}

Het onderzoek heeft plaatsgevonden in twee top klinische ziekenhuizen in Midden Nederland, binnen 4 intensive care's die tezamen 75 bedden tellen. In totaal zijn 206 familieleden van intensive care patiënten geïnterviewd, waarvan 100 familieleden van hartoperatiepatiënten en 106 familieleden van overige intensive care patiënten.

Gedurende de gehele analyse van het onderzoek zijn twee groepen te onderscheiden, te weten: (1) familieleden van patiënten die een hartoperatie hebben ondergaan en (2) familieleden van overige intensive care patiënten.

Familieleden uit beide onderzoeksgroepen hebben in volgorde van belang behoeften aan toegankelijkheid (gemiddelde score van 3.5 op een schaal van 1.0 geen belang tot 4.0 veel belang), behoeften aan informatie (gemiddelde score van 2.9) en behoeften aan ondersteuning (gemiddelde score van 2.4). De verschillen in behoeften tussen de twee groepen zijn klein, hooguit is er een tendens dat familieleden van overige intensive care patiënten meer behoeften aan informatie hebben.

Bij nadere beschouwing, door middel van multi-variate analyses, blijkt dat 4 factoren samenhangen met de opname-indicatie van de patiënt (één sociaal-demografische factor, één intensive care gelieerde factor, één ziektegebonden factor en één coping factor). Opvallend is dat familieleden van hartoperatiepatiënten en familieleden van overige intensive care patiënten verschillende eigenschappen zijn toe te schrijven. Familieleden van hartoperatiepatiënten worden over het algemeen geconfronteerd met een -wachttijd op opname van de patiënt, -de patiënt wordt niet mechanisch beademd, -familieleden zijn niet woonachtig in Utrecht/Gelderland en -scoren relatief laag op de copingstijl "sociale steun zoeken".

Familieleden van overige intensive care patiënten worden over het algemeen -niet geconfronteerd met een wachttijd op opname van de patiënt, -de patiënt wordt mechanisch beademd, -men is woonachtig in Utrecht/Gelderland en -men scoort relatief hoog op de copingstijl "sociale steun zoeken". 


\subsubsection{Determinanten en effecten}

Door de beïnvloedende factoren op te nemen in logistische regressie analyses is het mogelijk gebleken familieprofielen te ontwikkelen die een voorspellende waarde hebben voor de afzonderlijke behoeftecategorieën (figuur 10.1).

Figuur 10.1

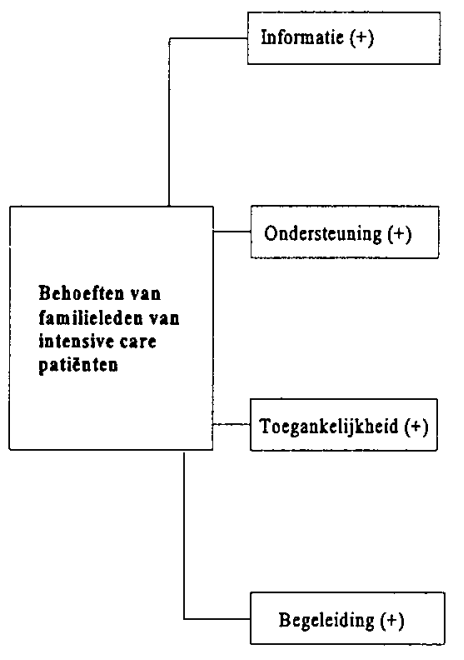

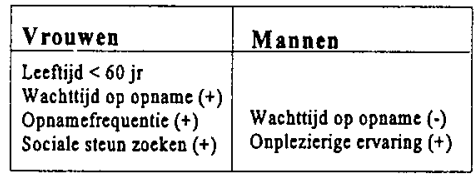

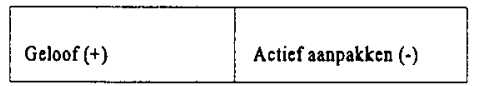

Bekend met de ICU (t)

Uitstel van de opname $(+)$

Onplezierige ervaring $(+)$

Onplezierige ervaring (+)

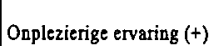

Opnamefrequentic (t)
Totale groep

Geslacht ( + )

Leeftijd $<60$ jaar

Wachttijd op opname

Onplezierige ervaring

Opnamefrequentie $(+)$

Sociale steun zoeken $(+)$

Geslacht ( $(?)$

Geloof $(+)$

Sociale steun zoeken $(+)$

Actief sanpakken (*)

Geslacht ( $\%$

Relatie (partner)

Uitstel van de opname $(+)$

Onplezierige ervaring $(+)$

Geslacht ( $(9)$

Onplezierige ervaring $(+)$

Opnamefrequentie $(+)$

Sociale steun zocken $(+)$

\section{Informatie}

Zes factoren (multi-variate analyse) hangen samen (figuur 10.1) met de behoeften aan informatie. Wanneer het familielid een vrouw is, jonger dan 60 jaar, er is geen sprake geweest van wachttijd op opname van de patiënt, het familielid heeft een onplezierige ervaring meegemaakt, de patiënt is eerder opgenomen geweest op de intensive care en het familielid prefereert de copingstijl "sociale steun zoeken", is er een grotere behoefte aan informatie.

Wanneer de onderzoeksgroep wordt gesplitst in mannelijke- en vrouwelijke familieleden, blijkt dat 5 factoren samenhangen met het geslacht van familieleden. Bij vrouwelijke familieleden speelt leeftijd, wachttijd op opname van de patiënt, opnamefrequentie van de patiënt en de copingstijl "sociale steun zoeken" een rol. Bij mannelijke familieleden speelt wachttijd op opname van de patiënt en een onplezierige ervaring op de intensive care een rol. 


\section{Ondersteuning}

Vier factoren (multi-variate analyse) hangen samen (figuur 10.1) met de behoeften aan ondersteuning. Wanneer het familielid een vrouw is, gelovig is, de copingstijl "sociale steun zoeken" prefereert en de copingstijl "actief aanpakken" niet prefereert, is er een grotere behoefte aan ondersteuning.

Wanneer de onderzoeksgroep wordt gesplitst in mannelijke- en vrouwelijke familieleden, blijkt dat 2 factoren samenhangen met het geslacht van familieleden.

Bij vrouwelijke familieleden speelt geloof een rol. Bij mannelijke familieleden speelt de copingstijl "actief aanpakken" een rol.

\section{Toegankelijkheid}

Vier factoren (multi-variate analyse) hangen samen (figuur 10.1) met de behoeften aan toegankelijkheid. Wanneer het familielid een vrouw is, partner van de patiënt, de opname van de patiënt uitgesteld is en het familielid een onplezierige ervaring heeft gehad, is er een grotere behoefte aan toegankelijkheid.

Wanneer de onderzoeksgroep wordt gesplitst in mannelijke- en vrouwelijke familieleden, blijkt dat 3 factoren samenhangen met het geslacht van familieleden. Bij vrouwelijke familieleden speelt bekendheid met de intensive care, uitstel van de opname van de patiënt en een onplezierige ervaring op de intensive care een rol. Bij mannelijke familieleden speelt een onplezierige ervaring op de intensive care een rol.

\section{Begeleiding}

Vier factoren (multi-variate analyse) hangen samen (figuur 10.1) met de behoeften aan begeleiding. Wanneer het familielid een vrouw is, een onplezierige ervaring heeft gehad, de patiënt eerder is opgenomen op de intensive care en de copingstijl "sociale steun zoeken" prefereert, is er een grotere behoefte aan begeleiding.

Wanneer de onderzoeksgroep wordt gesplitst in mannelijke- en vrouwelijke familieleden, blijkt dat 3 factoren samenhangen met het geslacht van familieleden. Bij vrouwelijke familieleden speelt een onplezierige ervaring op de intensive care en de opnamefrequentie van de patiënt een rol. Bij mannelijke familieleden speelt de copingstijl "sociale steun zoeken" een rol.

\subsubsection{Copinggedrag}

Om zicht te krijgen op de invloed van copinggedrag van familieleden op behoeften, zijn, de vier copingstijlen "actief aanpakken", "sociale steun zoeken", "afwachten en vermijden" en "palliatief gedrag" toegewezen aan fight- (het probleem aanpakken) en flight- (voor het probleem wegvluchten) gedrag (Janssen et al, in voorbereiding). Tevens is hierbij het instrumentele of emotionele karakter van dit gedrag aangegeven (Janssen et al., in voorbereiding).

In relatie tot behoeften van familieleden van intensive care patiënten kan copinggedrag gezien worden als bepaald geprefereerd gedrag dat in bepaalde mate de behoeften van familieleden beïnvloedt. 
Om hierover een indruk te krijgen is in eerste instantie het veronderstelde effect van copinggedrag op behoeften van familieleden beschreven waarbij de copinggedrag wordt ondergebracht in fight- en flight-gedrag en het instrumentele of emotionele karakter van dit gedrag (figuur 10.2).

Figur 10.2 Verondersteld en gemeten effect van copinggedrag op behoeften

\begin{tabular}{|l|c|c|c|c|}
\cline { 2 - 5 } \multicolumn{1}{c|}{} & Actief aanpakken & Afwachten en vermijden & Sociale steun zoeken & Palliatief gedrag \\
\cline { 2 - 5 } & Fight & Flight & Fight & Flight \\
\cline { 2 - 5 } & \multicolumn{2}{|c|}{ Instrumenteel } & $(+) \oplus$ & Emotioneel \\
\hline $\begin{array}{l}\text { Informatie } \\
\text { (instrumentele benadering) }\end{array}$ & $+\odot$ & - & $+\odot$ & 0 \\
\hline $\begin{array}{l}\text { Ondersteuning } \\
\text { (sociaal-emotionele benadering) }\end{array}$ & $(-) \odot$ & - & & \\
\hline $\begin{array}{l}\text { Toegankelijkheid } \\
\text { (structurr gerichte benadering) }\end{array}$ & + & - & $(+)$ & 0 \\
\hline
\end{tabular}

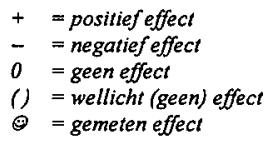

\subsubsection{Veronderstellingen versus resultaten}

De resultaten komen slechts gedeeltelijk overeen met het veronderstelde effect van copinggedrag van familieleden op behoeften. Met name de copingstijlen "actief aanpakken"en "sociale steun zoeken" hebben het veronderstelde effect op behoeften aan informatie en ondersteuning. Het veronderstelde effect op de behoeftecategorie "toegankelijkheid" is echter niet aangetoond.

Wat de copingstijlen "afwachten en vermijden"en "palliatief gedrag" betreft wordt het veronderstelde effect niet aangetoond. Beide stijlen hebben geen effect op de behoeftecategorieën "informatie en toegankelijkheid". Wel blijkt dat deze stijlen effect hebben op de behoeftecategorie "ondersteuning".

Concluderend kan gesteld worden dat de copingstijlen "actief aanpakken" en "sociale steun zoeken" gekenmerkt kunnen worden als effectief copinggedrag als het gaat om behoeften van familieleden aan informatie en ondersteuning. De copingstijlen "afwachten en vermijden"en "palliatief gedrag" kunnen gekenmerkt worden als ineffectief copinggedrag als het gaat om de drie behoeftecategorieën. Hierbij dient echter in ogenschouw genomen te worden dat ook de ineffectieve copingstijlen in beginsel effectief kunnen zijn voor familieleden (stressreductie op de korte termijn). Wanneer echter dit gedrag langer geprefereerd wordt zullen behoeftetekorten ontstaan. 


\subsubsection{Wat, wie en hoe?}

Om antwoord te geven op de vragen wat er precies moet gebeuren op de intensive care, wie in de ogen van familieleden in behoeften zouden moeten voorzien en hoe daadwerkelijk in de praktijk omgegaan is met de behoeften, is het noodzakelijk en nuttig om behoeften op itemniveau te beschouwen. Dit is voornamelijk het geval omdat in de praktijk behoeften zich niet gemakkelijk globaal laten vastleggen, met andere woorden: wat er precies gebeurt, is anders dan algemeen vinden. Bovendien gaat het in deze studie om belevingsonderzoek hetgeen impliceert dat beleving op behoefte-itemniveau kan verschillen.

Met behulp van de subvragen, waaruit 7 van de 18 behoefte-items bestaan, is gekeken naar het belang van de behoefte (wat), de gewenste behoefteverstrekker (wie) en daadwerkelijke resultaten (hoe).

In eerste instantie is gekeken naar het belang van de afzonderlijke behoefte-items. Van de 7 behoefte-items vindt meer dan $50 \%$ van de familieleden 5 items belangrijk (uitleg over de medische behandeling, aanwezigheid van een intensive care medewerker tijdens het eerste bezoek, aanwezigheid van een contactpersoon, informatie over een eventuele overplaatsing van de patiënt en ondersteuning door een intensive care medewerker). De overige 2 behoefteitems (uitleg over de apparatuur en kunnen spreken over ervaringen en gevoelens) vindt minder dan 50\% van de familieleden belangrijk. Deze resultaten komen over het algemeen goed overeen met de resultaten uit eerder onderzoek (Molter, 1979; Daley, 1984; Forrester et al., 1988; Kleinpell \& Powers, 1992; Foss \& Tenholder, 1993).

Duidelijk wordt dat de verpleegkundige in 50\% van de gevallen bij alle behoefte-items de gewenste behoefteverstrekker is. Uitzondering is hier de behoefte aan uitleg over de medische behandeling. Hier scoren de verpleegkundige en de arts over het algemeen gelijk.

Wanneer de resultaten beschouwd worden in relatie tot de gewenste behoefteverstrekker wordt duidelijk dat bij 5 (aanwezigheid van een intensive care medewerker tijdens het eerste bezoek aan de patiënt, aanwezigheid van een contactpersoon, informatie over een eventuele overplaatsing van de patiënt, ondersteuning door een intensive care medewerker en uitleg over de apparatuur) van de 7 behoefte-items de verpleegkundige in meer dan $50 \%$ van de gevallen voorziet in de behoeften.

\subsection{Beïnvloedende factoren}

Slechts bij 1 (behoeften aan ondersteuning door een intensive care medewerker) van de 7 behoefte-items is het item "een onplezierige ervaring" opgenomen in de regressie. Derhalve kan dit item uitsluitend gezien worden als een algemene tendens bij behoefte aan ondersteuning door de verpleegkundige op de intensive care. 


\subsection{Praktische implicaties}

De praktische implicaties bestaan daaruit dat we aan de verkregen resultaten richtlijnen kunnen ontlenen voor toekomstig (verpleegkundig) beleid ten behoeve van familieleden op de intensive care. Als zodanig is het van belang dat de resultaten op juiste wijze geïnterpreteerd en beoordeeld worden. Snelle conclusies op basis van geselecteerde resultaten welke niet in breder verband bezien worden, kunnen leiden tot reacties op basis van persoonlijke betrokkenheid die het onderzoek geen recht doen (bijvoorbeeld voortijdige publicaties in landelijke dagbladen, Algemeen Dagblad, 23 juni 1997).

Belangrijk is om stil te staan bij het feit dat er niet altijd iets hoeft te gebeuren. Regelmatig zijn familieleden tevreden en gaat alles naar wens. Ook hier is het van belang dat dit gedocumenteerd wordt om duidelijk te maken dat het gevoerde beleid gehandhaafd moet worden.

Met deze studie is niet bedoeld onderzoek te doen naar feitelijke (mis)standen ten aanzien van familieleden op de intensive care. Het gaat er om wat familieleden ervaren op de intensive care.

Derhalve dient onderhavige studie bezien te worden als belevingsonderzoek dat als basis kan dienen voor een maatschappelijke en professionele norm voor begeleiding van familieleden. Het is dan ook niet mogelijk om een waarde oordeel (goed of slecht) uit te spreken over de resultaten uit deze studie. Veel belangrijker is om te constateren dat, in het algemeen, in bijna $60 \%$ van de gevallen in behoeften van familieleden wordt voorzien. Tevens is duidelijk geworden waar verbetering kan worden bewerkstelligd. Resultaten uit onderhavig onderzoek kunnen een aanzet geven om te komen tot de, tot nu toe ontbroken, norm voor begeleiding van familieleden op de intensive care.

Wanneer men de zorg voor familieleden op de intensive care wil verbeteren, dan zijn daarvoor op grond van de bevindingen uit deze studie een aantal aanbevelingen te formuleren die onder te verdelen zijn naar respectievelijk:

* aanbevelingen ten aanzien van het verpleegkundig handelen gericht op familieleden van intensive care patiënten

* aanbevelingen ten aanzien van doelgerichte opleidings- en bijscholingsprogramma's gericht op de zorg voor familieleden van intensive care patiënten.

\subsubsection{Aanbevelingen ten aanzien van het verpleegkundig handelen gericht op familieleden van intensive care patiënten}

Over het algemeen blijken familieleden van intensive care patiënten op de intensive care een grote behoefte te hebben aan toegankelijkheid en informatie. Iets minder, maar beslist niet onbelangrijk is de behoefte aan ondersteuning op de intensive care. Daarnaast kan een aantal factoren aangewezen worden die bepalend zijn voor behoeften van familieleden en derhalve voor eventuele interventie in aanmerking komen. 
Uitvoering van zorg voor familieleden biedt gelegenheid voor uitbreiding van het verpleegkundig domein en stelt meer eisen aan de opleiding en ervaring van intensive care verpleegkundigen met alle uitdaging van dien.

Hier dient echter vooropgesteld te worden dat op de intensive care de zorg voor de patiënt volstrekt dominant is. Dit sluit echter niet uit dat het van belang is om tevens zorg aan de familieleden van intensive care patiënten te schenken. Derhalve dienen de resultaten uit onderhavige studie serieus genomen te worden, vooral als het gaat om behoeften aan toegankelijkheid en informatie en minder als het gaat om behoeften aan ondersteuning.

Het feit dat men te maken heeft met familieleden, wier algemene toekomstbeeld, ten gevolge van de levensbedreigende situatie waarin hun naaste verkeert, onvoorspelbaar is en plotseling kan veranderen, bepaalt in sterke mate de conditie waaronder intensive care verpleegkundigen moeten werken. Waar echter voor gezorgd moet worden is dat intensive care verpleegkundigen leren omgaan met dergelijke omstandigheden en in de opleiding hier goed op voorbereid worden. De combinatie van zorg voor de patiënt en familieleden op de intensive care vereist zowel aandacht voor instrumenteel-technische vaardigheden als sociaalemotionele vaardigheden. Intensive care medewerkers moeten een situatie creëren waarin familieleden het gevoel hebben niet in de weg te lopen. Een flexibele instelling en voortdurende afstemming op de behoeften van familieleden moet gezien worden als een noodzakelijke eis die aan intensive care verpleegkundigen gesteld moet worden.

Een mogelijkheid ter stimulering van bovenstaande zou de uitbreiding van een verpleegsysteem zijn, waarin familietoewijzing analoog met patiëntentoewijzing wordt toegepast. Door de uitbreiding van een dergelijk systeem, door middel van voorzieningen ten behoeve van informatie en toegankelijkheid, hebben verpleegkundigen de mogelijkheid de hen toegewezen familieleden in hun totaliteit te begeleiden en te betrekken bij het zorgverleningsproces van de patiënt. Voltooiing van een compleet en afgerond geheel kan in de praktijk een verrijking van de kwaliteit van de verpleegkundige taken betekenen. Eveneens kan verwacht worden dat een betere afstemming van verpleegkundige interventies op behoeften van familieleden leidt tot verhoging van de kwaliteit van zorg voor familieleden.

De uitbreiding van verpleegkundige taken door familietoewijzing heeft niet of nauwelijks verhoging van de werkdruk tot gevolg. Wel dient rekening te worden gehouden met het gevaar dat een systeem van familietoewijzing ontaardt in een scala van administratieve taken. Verhoging van kwaliteit van zorg voor familieleden leidt niet tot extreme activiteiten, doch behoort tot de professionele standaard van verpleegkundigen.

Een goede begeleiding bij het initiëren en implementeren van een systeem van zorg voor familieleden is noodzakelijk. Ook een duidelijk taakafbakening moet gezien worden als een vereiste voor optimaal systeem van zorg voor familieleden. Belangrijk is hier te weten welke taken, met betrekking tot familiebegeleiding, door de arts worden uitgevoerd en welke door de verpleegkundige. Bevordering van duidelijkheid in taken kan verkregen worden door structureel overleg en het geven van feedback aan elkaar. Dit biedt verpleegkundigen en artsen de gelegenheid tot het uitwisselen van ervaringen en gevoelens ten aanzien van familieleden. 
Een goed functionerend systeem van zorg voor familieleden, waarin door artsen en verpleegkundigen intensief wordt samengewerkt, kan als geëigend middel ter verbetering van familiebegeleiding op de intensive care worden gezien.

\subsubsection{Aanbevelingen ten aanzien van doelgerichte opleidings- en bijscholings-programma's}

In het voorgaande is reeds aan de orde gesteld dat het verbeteren van de zorg voor familieleden op de intensive care bevorderd kan worden middels een duidelijke taakafbakening door structureel overleg en het geven van feedback. Echter een belangrijke randvoorwaarde voor het slagen van deze aanpak is dat verpleegkundigen daadwerkelijk in staat zijn om behoeften van familieleden te signaleren en op een doeltreffende wijze daarop in gaan. Deze vaardigheden kunnen ontwikkeld worden tijdens de opleiding, respectievelijk bij- en nascholing.

Een ander punt waaraan opleidings- en bijscholingsprogramma's aandacht zouden moeten besteden is het begeleiden van familieleden die in stresserende situaties verkeren, met andere woorden de door familieleden gehanteerde copingstrategieën. Een sociale steun zoekende aanpak van familieleden leidt tot toename van behoeften. In de opleiding zouden verpleegkundigen geleerd moeten worden inzicht te krijgen in copingstrategieën die door familieleden gehanteerd worden en het meest effectief zijn.

Tot slot dienen opleidingen ruime aandacht te besteden aan de daadwerkelijk behoeften van familieleden op de intensive care en het op een gestructureerde wijzen opnemen van deze behoeften in een systeem van zorg voor familieleden.

\subsection{Aanbevelingen voor verder onderzoek}

Uit het onderhavig onderzoek is naar voren gekomen dat er, met betrekking tot behoeften van familieleden van intensive care patiënten, een aantal aspecten is aan te wijzen die samenhangen met sociaal-demografische kenmerken van het familielid, ziektegebonden kenmerken van de patiënt, intensive care gelieerde kenmerken van de organisatie en copingstrategieën van het familielid. Een volgende stap zou kunnen zijn dat manipulatie van beïnvloedende kenmerken meer duidelijkheid zou kunnen verschaffen over de samenhang van beïnvloedende kenmerken en behoeften van familieleden. Voorts zou in een dergelijke onderzoekslijn de link naar kwaliteit van zorg voor familieleden en een afbakening en integratie van de rol van de arts op het onderhavige gebied kunnen plaatsvinden. Op basis van dergelijk onderzoek kunnen meer concrete en onderbouwde aanbevelingen voor projecten van zorg voor familieleden op de intensive care gedaan worden.

Een ander aandachtspunt is de onderlinge samenhang tussen beïnvloedende factoren en gehanteerde copingstrategieën om te achterhalen wat de oorzaak-gevolg relatie is met betrekking tot behoeften van familieleden. 
Nog een stap zou kunnen zijn om onderzoek te doen naar de inschatting van behoeften van familieleden door intensive care verpleegkundigen en artsen. Op deze wijze zou inzicht verkregen kunnen worden in de kwaliteit van familiebegeleiding vanuit het gezichtspunt van de zorgverleners. Wanneer deze resultaten met de resultaten uit onderhavige studie zouden kunnen worden vergeleken, kunnen duidelijke richtlijnen ter verbetering van de zorg voor familieleden verkregen worden wanneer subgroepanalyses worden toegepast.

Het aanvankelijk in vier schalen onderverdeelde meetinstrument is in een latere fase in drie schalen geherstructureerd. Wanneer in beginsel het meetinstrument in drie schalen zou zijn opgezet had wellicht een hogere interne consistentie van de afzonderlijke schalen verkregen kunnen worden. Derhalve is het aan te bevelen onderzoek naar behoeften van familieleden, op grond van de driedeling van behoeften (informatie, ondersteuning en toegankelijkheid) uit onderhavige studie, voort te zetten ten einde de vragenlijst te verbeteren.

Zoals uit literatuur blijkt (Daley, 1984) hebben verpleegkundigen de neiging informatie te verstrekken waaraan zij denken dat familieleden behoefte hebben. Het zou daarom interessant zijn te achterhalen hoe verpleegkundigen behoeften van familieleden op de intensive care inschatten. Met behulp van die resultaten kunnen overeenkomsten met de resultaten uit deze studie worden geformaliseerd en verschillen worden aangepast op de wensen van familieleden.

Zoals in hoofdstuk 9 is beschreven, lijkt er een onderlinge behoeftestructuur te bestaan die overeenkomsten vertoont tussen studies uit de Verenigde Staten en onderhavige studie. Aan te bevelen is om onderzoek voort te zetten naar overeenkomsten. Hierbij kan zowel gedacht worden aan onderzoek op behoefte-item niveau als aan onderzoek op behoeftecategorie niveau.

Een laatste aanbeveling is het doen van observatieonderzoek. Uit de onderzoeksresultaten blijkt dat meer dan $50 \%$ van de familieleden op de gewenste wijze en door de gewenste behoefteverstrekker voorzien wordt in behoeften. Toch is het zo dat een belangrijk deel van de onderzoekspopulatie de ervaring heeft dat niet in de gewenste behoeften is voorzien.

De vraag is of familieleden bijvoorbeeld daadwerkelijk niet zijn geïnformeerd, of dat men niet of slechts selectief in staat is gebleken om de informatie op te nemen. Ook bestaat de mogelijkheid dat informatie wel is gegeven maar niet in begrijpelijke taal. Om hierin meer inzicht te krijgen zou observatieonderzoek een belangrijk middel kunnen zijn. 


\section{SAMENVATTING}

\section{Inleiding}

In dit laatste hoofdstuk wordt een samenvatting gegeven van onderhavige studie naar behoeften van familieleden op de intensive care. Dit hoofdstuk bestaat uit vier paragrafen. Deze zijn achtereenvolgens de aanleiding en theoretische achtergrond van de studie, onderzoeksvragen en onderzoeksmethodologie, de resultaten en de praktische implicaties en aanbevelingen.

\section{Aanleiding en theoretische achtergrond van de studie}

De aanleiding voor deze studie is tweeledig. Om te beginnen is deze gelegen in de relatieve verwaarlozing van familieleden van intensive care patiënten. Over het algemeen kan men er van uit gaan dat patiënten die worden opgenomen op de intensive care niet of nauwelijks aanspreekbaar zijn en zich niet bewust zijn van de situatie waarin zij verkeren. Dit in tegenstelling tot hun familieleden, die plotseling geconfronteerd worden met opname van hun naaste op de intensive care en zich van het ene op het andere moment in een situatie van angst, bedreiging en afhankelijkheid bevinden. Gebeurtenissen op de intensive care zijn vaak zo ingrijpend dat familieleden moeite hebben om met de situatie om te gaan. Tot voor kort kon een gebrek aan (onderzoeks-) belangstelling voor zaken als behoeften van familieleden op de intensive care gesignaleerd worden. Een mogelijke oorzaak hiervan zou kunnen zijn dat verpleegkundigen problemen bespreken met familieleden die zij zelf als probleem ervaren en/of signaleren. Hierbij gaan verpleegkundigen er van uit dat deze gesignaleerde problemen ook door familieleden als problemen ervaren worden. De laatste jaren komt hierin verandering en ontstaat een toenemende interesse voor de samenwerking tussen hulpvrager en hulpverlener. Zo worden bijvoorbeeld patiënten steeds meer betrokken bij zorg- en hulpvragen. Verpleegplannen worden, met behulp van een verpleegkundige anamnese, door de verpleegkundige in samenspraak met de patiënt opgesteld. Familieleden worden hierbij niet of nauwelijks betrokken. Toch zouden, binnen de verpleegkundige anamnese, ook behoeften van familieleden besproken moeten worden. Op deze wijze kunnen gesignaleerde problemen getoetst worden en worden familieleden in de gelegenheid gesteld wensen en verwachtingen kenbaar te maken. Zo ontstaan mogelijkheden voor verpleegkundige interventies, gericht op familieleden.

De tweede aanleiding is gelegen in de turbulente ontwikkelingen in de gezondheidszorg die de zorg voor patiënt en familieleden (zullen) beïnvloeden. Met steeds verder doorgevoerde bezuinigingsrondes vanuit de overheid enerzijds en hoger gestelde kwaliteitseisen anderzijds wordt de marge waarin de verpleegkundige haar beroep dient uit te oefenen steeds smaller. De wet B.I.G. (Beroepen Individuele Gezondheidszorg, 1994) heeft tot gevolg dat verpleegkundigen verantwoording moeten kunnen afleggen over de wijze waarop de zorg voor patiënten en familieleden is uitgevoerd. 
De Kwaliteitswet Zorginstellingen (1996), de W.G.B.O. (Wet op de Geneeskundige Behandelings Overeenkomst, 1995), de Wet Klachtrecht Cliënten Zorgsector (1995) en de Wet Medezeggenschap Cliënten Zorginstellingen (in voorbereiding) dragen er toe bij dat patiënt en familie een steeds kritischer houding richting zorgverlener aannemen.

De theoretische basis voor deze studie wordt gevormd door enerzijds bevindingen uit empirisch materiaal (Hampe, 1975; Molter, 1979; McGregor et al., 1981; Yoder \& Jones, 1982; Bozett et al., 1983; Daley, 1984; O'Neill-Norris en Grove, 1986; Mclvor en Thompson, 1988; Dockter et al., 1988; McHale en Bellinger, 1988; Leske, 1988; Liddle, 1988; Norheim, 1989; Forrester et al.,1990; Chartier \& Coutu-Wakulczyk, 1989; Freichels, 1991; Koller, 1991; Farrel en Frost, 1992; Murphy \& Forrester, 1992; Titler \& Walsh, 1992; Murphy et al., 1992; Henneman et al., 1992; Biley \& Gibbons., Pender, 1993; DovisMartin, 1994), anderzijds wordt uitgegaan van het Neuman Systems Model (Neuman, 1995).

In deze studie worden behoeften in het algemeen, op grond van empirisch materiaal (Daley, 1984; Leske, 1988) onderscheiden in (1) de aard van de behoeften en (2) de mate (het belang) van behoeften. Daley (1984) en Leske (1988) maakten gebruik van Molter's Critical Care Family Needs Inventory, 1979 (46 items) en clusterden de behoefte-items, op grond van de aard van de behoeften, in behoeftecategorieën. Daley (1984) bracht de 46 behoefte-items onder in 6 categorieën (1) the need for relief of anxiety, (2) the need for information, (3) the need to be be with the patient, (4) the need to be helpful to the patient, (5) the need for support and ventilation en (6) personal needs. Leske (1988) bracht de 46 behoefte-items onder in 5 categorieën (1) support needs, (2) comfort needs, (3) information needs, (4) proximity needs en (5) assurance needs.

Daarna is een modificatie in het model aangebracht gericht op secundaire verpleegkundige interventies, waarbij met name de drie behoeftecategorieën die in deze studie gemeten zijn, benoemd worden. In deze herformulering van het Neuman Systems Model (Neuman, 1995) zijn drie begrippen toegevoegd (behoefte aan informatie, ondersteuning en toegankelijkheid). In deze begrippen kunnen de behoefte-items zoals genoemd in het Neuman Systems Model (Neuman, 1995) worden opgenomen. Door middel van onderhavige studie is het gelukt om behoeften van familieleden van intensive care patiënten in kaart te brengen en aannemelijk te maken dat de drie behoeftecategorieën vruchtbaar gebruikt kunnen worden. In dit onderzoek wordt voornamelijk uitgegaan van behoeftecategorieën. De keuze voor categorieën is gebaseerd op bevindingen uit empirisch materiaal Daley (1984) en Leske (1988).

Begripsmatig is bij de ontwikkeling van de behoeftecategorieën een onderscheid gemaakt tussen instrumenteel gerichte behoeften, sociaal emotioneel gerichte behoeften en op structuur gerichte behoeften. Oorspronkelijk waren ook op communicatie gerichte behoeften als categorie aangemerkt.

Factoranalyse van de resultaten leidt echter eerder tot een voorkeur voor een categorische driedeling van behoeften van familieleden dan tot een vierdeling. De behoeften van familieleden zijn onder te brengen in drie behoeftecategorieën, te weten: (1) behoeften aan informatie, (2) behoeften aan ondersteuning en (3) behoeften aan toegankelijkheid. De afzonderlijke behoeften aan communicatie spreiden zich over de andere categorieën. Communicatie is kennelijk een aspect van de behoeften aan (1) informatie, (2) ondersteuning en (3) toegankelijkheid.

Eveneens op basis van de interne consistentie van de gehele behoeftelijst kunnen informatie, 
ondersteuning en toegankelijkheid gezamenlijk gezien worden als dimensies van een meer abstracte behoefte aan begeleiding.

Het Neuman Systems Model (Neuman, 1995) is gebaseerd op verscheidende theorieën, n.l. systeem-theorie, stress-copingtheorie en preventietheorie. Preventie is binnen Neuman's model (Neuman, 1995) het fundament van waaruit het verpleegkundig handelen gestalte wordt gegeven. Neuman (Neuman, 1995) deelt verpleegkundige interventies onder in drie categorieën (primair preventieve interventies, secundair preventieve interventies en tertiair preventieve interventies). Primair preventieve interventies zijn gericht op het bevorderen van de gezondheid. Deze interventies vinden plaats wanneer stressoren verwacht worden of reeds aanwezig zijn, maar nog geen verstoringen hebben veroorzaakt. Secundair preventieve interventies zijn gericht op het herstellen van de gezondheid en worden uitgevoerd nadat stressoren het evenwicht en daarmee de gezondheid hebben verstoord. Tertiair preventieve interventies zijn gericht op het behouden van de gezondheid en vinden plaats tijdens de herstelfase. Uitgaande van het Neuman Systems Model (Neuman, 1995) is onderhavige studie gericht op secundaire verpleegkundige interventies ten behoeve van familieleden op de intensive care.

Uitgaande van Neuman's Systems Model (Neuman, 1995) richt deze studie zich op secundaire verpleegkundige interventies ten behoeve van behoeften van familieleden op de intensive care. Zoals uit tabel 2.2.1 valt af te leiden, is de secundaire interventiestrategie gericht op "assist family spiritual and psychosocial" een strategie gericht op interventies die benoemd zouden kunnen worden onder "ondersteunende interventies". Ook Molter (1979), Daley (1984) en Leske (1991 \& 1992) beschrijven de behoeftecategorie "needs for support".

"Answer questions honestly, family communication, provide assurance regarding treatments/prognosis en update family regularly" zijn gericht op "informatieve interventies". Bovengenoemde onderzoekers spreken hier eveneens van "needs for information". Hoewel geen van de onderzoekers behoeften op het gebied van toegankelijkheid daadwerkelijk als zodanig benoemt en categoriseert, valt uit het model van Neuman (Neuman, 1995) af te leiden dat "liberal visitation" en "family involvement in careplanning" als belangrijke voorwaarden gezien kunnen worden om in behoeften te voorzien.

\section{Onderzoeksvragen en onderzoeksmethodologie}

De bevindingen in de eerste twee hoofdstukken van dit proefschrift leiden tot de conclusie dat de resultaten (categorisering van behoefte-items en aangetoonde invloed van sociaaldemografische en overige factoren) uit de studies van Leske $(1988,1991,1992)$ toegepast binnen het interventieschema van Neuman (Neuman, 1995) en de copingtheorie van Lazarus (1966) een geschikt uitgangspunt vormen voor de concrete invulling van het theoretisch kader van deze studie.

Tevens blijkt dat een aantal wijzigingen de bruikbaarheid van het model kunnen bevorderen. Het categoriseren van behoefte-items in behoeftecategorieën en het betrekken van een aantal specifieke factoren (sociaal-demografische-, intensive care gelieerde-, ziektegebonden- en copingfactoren) is enerzijds gebaseerd op theoretische overwegingen en anderzijds op de specifieke kenmerken van de intensive care. 
Onderzoeksmodel

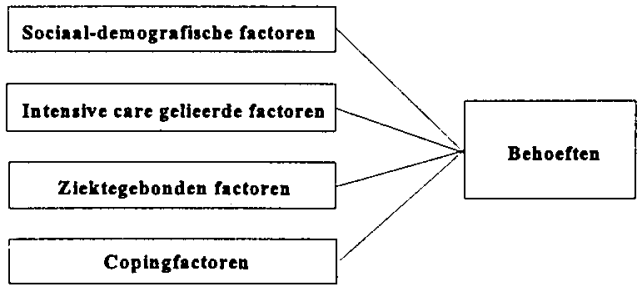

\section{Onderzoeksvragen}

Om de onderzoeksvragen te beantwoorden is in deze studie gekozen voor een verklarende aanpak met open vraagstellingen. Een aantal vraagstellingen zijn direct uit het onderzoeksmodel af te leiden. $\mathrm{Zij}$ vormen dan ook de centrale vraagstellingen in deze studie.

\section{Centrale vraagstellingen}

\section{Welke behoeften hebben familieleden van intensive care patiënten ?}

Op grond van de literatuurstudie wordt verwacht dat familieleden van intensive care patiënten behoeften hebben op het gebied van informatie, ondersteuning en toegankelijkheid.

Hoewel veel onderzoekers over het algemeen behoeften hebben gemeten op item nivo en ook Neuman in haar interventieschema (Neuman, 1995) slechts enkele behoeften benoemt, is uit de literatuur en uit het eigen onderzoek af te leiden dat behoeften van familieleden onder te brengen zijn in drie, duidelijk af te bakenen, gebieden. Deze studie richt zich, op grond van bovengenoemde argumentatie, dan ook op deze drie gebieden (informatie, ondersteuning en toegankelijkheid). Hoewel geen van de genoemde onderzoekers zich richt op behoeften van familieleden aan begeleiding in het algemeen, waarbij begeleiding gezien dient te worden als kapstok voor de drie behoeftecategorieën, richt deze studie zich, naast de drie behoeftecategorieën, ook op behoeften aan begeleiding.

Naast het belang van behoeften van familieleden van intensive care patiënten is het van belang te weten wie, in de ogen van familieleden, in de behoeften zou moeten voorzien.

Hierover hebben slechts enkele onderzoekers een uitspraak gedaan (Molter, 1979; Daley, 1984). Tevens vormt in deze studies de keuze tussen uitsluitend de arts en de verpleegkundige een beperking.

Belangrijker is te weten of er daadwerkelijk in behoeften op de intensive care wordt voorzien en door wie. De laatste twee vragen zijn slechts in enkele andere studies besproken (Quinn et 
al., 1996; Zazpe et al., 1997). Hierbij dient te worden opgemerkt dat deze onderzoekers uitsluitend tevredenheid hebben gemeten op behoefte-itemniveau. Geen van de onderzoekers spreekt over eventueel sociale wenselijk antwoordgedrag van de respondenten.

Deze studie richt zich dan ook niet alleen op behoeften van familieleden, maar ook op de vragen wie in de behoeften zouden moeten voorzien, of er in de behoeften is voorzien en door wie er in de behoeften is voorzien. Met name de laatste vragen geven zicht op de legitimatie van familiebegeleiding door verpleegkundigen of anderen en de kwaliteit van familiebegeleiding op de intensive care.

\section{Wat is het effect van onafhankelijke en overige factoren op behoeften van familieleden?}

Uit de literatuur (hoofdstuk 2) is gebleken dat sociaal-demografische factoren zoals leeftijd, geslacht en de relatie van het familielid met de patiënt, van invloed zijn op behoeften van familieleden op de intensive care. Ook ziektegebonden factoren, zoals bekendheid met de intensive care, de opname-indicatie en de diagnose van de patiënt, spelen in de literatuur een beïnvloedende rol. Intensive care gelieerde factoren zoals wachttijd op opname of het feit dat de opname van de patiënt is uitgesteld nadat deze gepland is, zijn niet eerder onderzocht, terwijl, in dit onderzoek, wel invloed wordt verondersteld. Tot slot wordt in deze studie verwacht dat copinggedrag van familieleden van invloed is op behoeften van familieleden. Ondanks het feit dat veel studies verricht zijn naar copinggedrag, is slechts een enkele studie gedaan naar copinggedrag bij familieleden van harttransplantatiepatiënten gedurende de wachtperiode op het donorhart (Nolan et al., 1992). Over het algemeen wordt, in de literatuur, de nadruk gelegd op de relatie tussen ingrijpende gebeurtenissen en copingstijlen (Feij et al., 1990). Om bovenstaande redenen wordt in dit onderzoek het effect van onafhankelijke en overige factoren op behoeften van familieleden onderzocht.

\section{Onderzoeksmethodologie}

\section{Onderzoekspopulatie}

In totaal zijn 229 familieleden, uit twee ziekenhuizen op vier intensive care afdelingen, gevraagd deel te nemen aan het onderzoek. De vragenlijst werd, in het bijzijn van de onderzoekers aan de familieleden voorgelegd. Nadat de vragen door de onderzoekers aan de familieleden gesteld waren en de familieleden de vragen (mee) gelezen hadden werden de antwoorden genoteerd (face-to-face interview methode) (Emans, 1986).

\section{Respons}

Het responspercentage voor de totale onderzoekspopulatie is $90 \%$ (tabel 4.4 ).

De totale onderzoeksgroep is opgebouwd uit 106 familieleden van algemene intensive care patiënten en 100 familieleden van hartoperatiepatiënten op de intensive care.

\section{Methode}

Om de verschillende variabelen uit het onderzoeksmodel te meten, is gebruik gemaakt van een mondelinge (algemene vragen en behoeftevragen) en een schriftelijke (coping) interviewmethode met behulp van drie vragenlijsten (algemene vragenlijst, behoeftelijst en copinglijst).

De interviews vonden plaats in de periode van oktober 1992 tot mei 1993 op volstrekt 
willekeurige dagen. Op deze dagen werd eerst een inventarisatie gemaakt van het aantal patiënten dat nog niet langer dan 72 uur op de intensive care was opgenomen. Tijdens de bezoekuren werden familieleden van deze patiënten benaderd.

Er werd een korte uitleg gegeven van het doel van het onderzoek, de voorwaarden (vrijwilligheid en anonimiteit) en de wijze waarop de vragenlijst zou worden afgenomen.

Daarna werd gevraagd of het familielid zijn of haar medewerking wilde verlenen. Bij een positief resultaat werd de vragenlijst ofwel direct afgenomen, of er werd een afspraak gemaakt voor de volgende dag (mits de 72 uur hierdoor niet werden overschreden).

In een speciaal voor dit doel beschikbaar gestelde ruimte werd het interview afgenomen. De onderzoeker stelde de vragen, gaf zonodig korte uitleg als de vraag niet werd begrepen en vulde de antwoorden in. De familieleden vulden zelf de verkorte Utrechtse Coping Lijst (Janssen et al, in voorbereiding) in. Het interview had een gemiddelde duur van 45 minuten.

De vragenlijsten werden in het totaal door drie studenten (doctoraalstudenten van de Universiteit Maastricht, afstudeerrichting Verplegingswetenschap) en de onderzoeker afgenomen. Om tot afstemming te komen met betrekking tot het uniform afnemen van de vragenlijst (het voorkomen van interviewersbias) zijn eerst afspraken gemaakt (de onderzoekers lazen alleen de vragen voor, eventuele verduidelijking van de vragen vond op éénduidige wijze plaats, er werden geen voorbeelden gegeven) waarna verschillende oefensessies plaatsvonden (assistent-onderzoekers oefenden op elkaar onder supervisie van de onderzoeker). Tot slot werden de eerste familieleden door twee onderzoekers geïnterviewd, waarbij de onderzoekers beurtelings interviewden en toekeken. Na het mondeling afnemen van de vragenlijst werd het familielid gevraagd de copinglijst zelfstandig in te vullen.

Familieleden konden zelf het tijdstip voor het invullen van de vragenlijst bepalen.

Om de behoeften van familieleden van intensive care patiënten te analyseren is een onderscheid gemaakt tussen familieleden van hartoperatiepatiënten en overige intensive care patiënten. Hiervoor zijn $\chi 2$ analyses toegepast. Om de invloed van sociaal-demografische factoren, intensive care gelieerde factoren en ziektegebonden factoren op behoeften te analyseren zijn zowel $\chi 2$ analyses als t-toetsen toegepast. Om de invloed van copingfactoren op behoeften van familieleden te analyseren zijn eveneens $\chi^{2}$ analyses en t-toetsen toegepast. Tot slot zijn, met behulp van aspectmetingen, voorspellingen gedaan voor specifieke groepen familieleden gericht op de behoeftecategorieën. Met behulp hiervan zijn praktisch relevante familieprofielen ontwikkeld.

\section{Resultaten}

\section{Familieleden van hartoperatiepatiënten versus familieleden van overige intensive care patienten}

In deze studie is geen verschil in behoeften aangetoond tussen familieleden van hartoperatiepatiënten en familieleden van overige intensive care patiënten. Familieleden vinden toegankelijkheid in de intensive care het meest belangrijk (meanscore 3.5), gevolgd door informatie (meanscore 2.9). De minst belangrijke behoefte is ondersteuning (meanscore van 2.4).

Behoeften aan begeleiding, het totaal van de drie hiervoor genoemde behoeftecategorieën 
heeft een gemiddelde score van 2.9. Familieleden van hartoperatiepatiënten hebben meer te maken met een wachttijd op opname van de patiënten dan familieleden van overige intensive care patiënten. Ook wordt de opname van hartoperatiepatiënten vaker uitgesteld dan bij overige intensive care patiënten.

Familieleden van hartoperatiepatiënten zijn vaker geïnterviewd in de eerste 48 uur van de opname van de patiënt op de intensive care dan familieleden van overige intensive care patiënten. De laatste groep blijft, in tegenstelling tot hartoperatiepatiënten, langer op de intensive care zodat ook de derde dag van de opname (tot 72 uur na opname) familieleden geïnterviewd konden worden.

Hartoperatiepatiënten worden vaker gepland opgenomen dan overige intensive care patiënten. Overige intensive care patiënten worden vaker mechanisch beademd. De mate van levensbedreiging van de patiënt wordt bij overige intensive care patiënten zowel door de verpleegkundige als door de familieleden zelf, ernstiger ingeschat dan bij hart-operatiepatiënten. In beide onderzoeksgroepen schat de familie de mate levensbedreiging van de patiënt duidelijk ernstiger in dan de verpleegkundige.

Fanilieleden van overige intensive care patiënten hebben een duidelijk hogere score (2.5) op de copingstijl "sociale steun zoeken" dan familieleden van hartoperatiepatiënten (2.2). De andere copingstijlen (actief aanpakken, afwachten en vermijden en palliatief gedrag) komen in beide onderzoeksgroepen evenveel voor.

Tot slot zijn, met behulp van logistische regressie analyse, voorspellingen gedaan voor de twee onderzoeksgroepen (familieleden van hartoperatiepatiënten en familieleden van overige intensive care patiënten) gericht op behoeften aan informatie, ondersteuning, toegankelijkheid en begeleiding. Hoewel het slechts om een globale beschouwing van de onafhankelijke variabelen gaat, zijn uit theoretische en praktische overwegingen twee profielen ontwikkeld (Harten en Overigen). Profiel Harten is het familielid van een patiënt die te maken heeft gehad met een wachttijd op opname, niet mechanisch beademd wordt, niet in de provincie Utrecht of Gelderland woont en relatief weinig sociale steun zoekt. Van de 99 familieleden die aan de kenmerken uit de regressie voldoen is $75 \%$ familielid van een hartoperatiepatiënt.

Bij een omgekeerde redenering (familielid van een patiënt die niet te maken heeft gehad met een wachttijd op opname, beademd wordt, in de provincie Utrecht of Gelderland woont en relatief veel sociale steun zoekt) is $71 \%$ van de 106 respondenten familie van een overige intensive care patiënt (Profiel Overigen). Van de 205 in het model geplaatste familieleden is 73\% goed geplaatst.

\section{Beïnvloedende factoren}

Behoeften van familieleden op de intensive care worden beïnvloed door verschillende onafhankelijke en overige factoren. Zowel in de totale onderzoeksgroep als in de beide afzonderlijke onderzoeksgroepen (familieleden van hartoperatiepatiënten en familieleden van overige intensive care patiënten) is invloed te zien. 
In totaal zijn 15 factoren van invloed, waarvan 5 sociaal-demografische factoren (geslacht, geloof, leeftijd, relatie, bekendheid met de intensive care), 3 intensive care gelieerde factoren (onplezierige ervaring, wachttijd op opname, uitstel van de opname), 3 ziektegebonden factoren (mechanische beademing, opnamefrequentie, ingeschatte levensbedreiging) en 4 copingstijlen ("actief aanpakken", "sociale steun zoeken", "afwachten en vermijden", "palliatief gedrag”).

Vervolgens zijn opnieuw, met behulp van logistische regressie analyse, voorspellingen gedaan gericht op behoeftecategorieën. Hiervoor zijn alle beïnvloedende variabelen opgenomen in de regressie gecontroleerd voor de behoeftecategorieën. Omdat het geslacht van familieleden een rol speelt in alle behoeftecategorieën is tot slot een logistische regressie analyse uitgevoerd voor vrouwelijke en mannelijke respondenten afzonderlijk. Duidelijk wordt dat, met behulp van de ontwikkelde profielen, de zorg voor familieleden meer specifiek kan worden afgestemd op de behoeften van familieleden op de intensive care. Voor mannelijke familieleden speelt een onplezierige ervaring, de plotselinge opname van de patiënt en copinggedrag een rol bij behoeften op de intensive care. Voor vrouwelijke familieleden speelt leeftijd, wachttijd, bekendheid, uitstel van de opname, opnamefrequentie van de patiënt, een onplezierige ervaring en copinggedrag een rol.

\section{Typologie binnen de behoefte-items}

Met afzonderlijke behoefte-items zijn vervolgens drie typen familieleden ontwikkeld.

De typologie is toegepast op behoefte-item-nivo binnen de behoeftecategorieën.

Alleen de behoefte-items die bestaan uit vier (sub)vragen, $(A)$ vindt u het belangrijk?, (B) door wie wilt $u$ dat dit gedaan wordt?, (C) is het gedaan? en (D) door wie is het gedaan?) en als zodanig antwoord geven op de deelvraagstellingen die zijn afgeleid van de eerste centrale onderzoeksvraag (hoofdstuk 3) zijn in de typologie opgenomen.

Op deze wijze is gepoogd respondenten te classificeren in typen familieleden waarbij de antwoorden op de subvragen binnen één behoefte-item de legitimatie voor de typering vormt.

Daar waar de arts en de gastvrouw een relatief kleine rol spelen binnen de wensen van familieleden speelt de verpleegkundige de hoofdrol. Op het gebied van behoeften aan ondersteuning wordt deze rol door de verpleegkundigen in $58 \%$ van de gevallen daadwerkelijk ingevuld. Wanneer het gaat om informatie, vullen verpleegkundigen in $59 \%$ van de gevallen de gewenste rol in. Verpleegkundigen op de intensive care dienen zich te bezinnen over de invulling van hun rol als ondersteuner en informatieverstrekker.

Zowel de relatie van het familielid met de patiënt, de leeftijd van het familielid als het woongebied van het familielid zijn van invloed op de typen familieleden.

Van de intensive care gelieerde factoren spelen vooral de wachttijd op opname van de patiënt en een onplezierige ervaring van het familielid een beïnvloedende rol. Van de ziektegebonden variabelen zijn de opnamefrequentie van de patiënt, het feit of de patiënt mechanische beademd wordt en de planning van de opname van de patiënt (spoed of geen spoed) van invloed op de typologie van familieleden. Bij de copingstijlen wordt een invloed van alle copingstijlen (4) gezien op de typologie van familieleden. 
Als het gaat om de aanwezigheid van een intensive care medewerker tijdens het eerste bezoek aan de patiënt ligt de voorkeur bij de verpleegkundige. Ook de uitleg van de medische behandeling van de patiënt zien familieleden graag door de verpleegkundige gerealiseerd. $\mathrm{Bij}$ de contactpersoon wordt de voorkeur aan een andere discipline gegeven.

Familieleden op de intensive care worden bij voorkeur ondersteund door de verpleegkundige. Ook informatie over een eventuele overplaatsing van de patiënt naar een andere afdeling of ziekenhuis wensen familieleden van de verpleegkundige te krijgen. Wanneer het gaat om de uitleg van de apparatuur die bij de patiënt wordt gebruikt, wordt de voorkeur aan de verpleegkundige gegeven. Opvallend is dat familieleden met een hogere score op de copingstijlen "actief aanpakken en sociale steun zoeken" over het algemeen de voorkeur geven aan de verpleegkundige. Een hogere score op de copingstijlen "afwachten en vermijden" leidt tot voorkeur voor een andere discipline. In sommige gevallen leiden deze copingstijlen bij familieleden tot de wens geen informatie of ondersteuning te ontvangen.

Op de behoefte aan "het kunnen spreken over ervaringen en gevoelens op de intensive care" hebben de factoren zoals beschreven in dit hoofdstuk geen invloed. Mogelijk ligt hieraan het gebrek aan belangstelling van familieleden (135 van de 176 in de typologie opgenomen familieleden) voor deze behoefte ten grondslag.

\section{Praktische implicaties en aanbevelingen}

De praktische implicaties uit deze studie bestaan daaruit dat aan de verkregen resultaten richtlijnen te ontlenen zijn voor toekomstig verpleegkundig beleid ten behoeve van familieleden op de intensive care. Wanneer men zorg voor familieleden op de intensive care wil verbeteren, dan zijn daarvoor op grond van de bevindingen uit deze studie een aantal praktische implicaties tot gevolg, onder te verdelen naar respectievelijk:

* implicaties ten aanzien van het verpleegkundig handelen gericht op familieleden op de intensive care

* implicaties ten aanzien van doelgerichte opleidings- en bijscholingsprogramma's gericht op zorg voor familieleden.

\section{Praktische implicaties}

\section{Gericht op het verpleegkundig handelen}

Over het algemeen blijken familieleden van intensive care patiënten op de intensive care een grote behoefte te hebben aan toegankelijkheid en informatie. Iets minder, maar beslist niet onbelangrijk, is de behoefte aan ondersteuning op de intensive care. Daarnaast kan een aantal factoren aangewezen worden die bepalend zijn voor behoeften van familieleden en derhalve voor eventuele interventie in aanmerking komen. Verpleegkundigen zouden werkmethoden en procedures moeten hanteren die bepalend zijn voor positieve reacties van familieleden.

Dit vergt een professionele houding van verpleegkundigen en een attitude waaruit betrokkenheid en verantwoordelijkheid blijkt. Om verpleegkundige interventies gericht op familieleden op een professionele wijze uit te voeren zal de verpleegkundige moeten beschikken over een theoretisch kader van waaruit het handelen gestalte krijgt. 
Verpleegkundigen moeten zicht hebben op de situatie waarin familieleden verkeren en tevens dienen zij in staat te zijn om, met behulp van beïnvloedende factoren, de hulpvraag van familieleden te analyseren en te toetsen. Op deze wijze neemt professionele zorg voor familieleden de plaats in van intuïtief handelen op basis van persoonlijke (verpleegkundige) schattingen.

Ondanks het feit dat familieleden een dominante positie toeschrijven aan de verpleegkundige is het zo dat ook van de arts, als het gaat om de medische informatie, professioneel handelen verwacht mag worden. De arts is niet alleen bij wet verplicht familieleden te informeren maar ook om deze informatie in begrijpelijke taal te verstrekken.

Ook de medische professie zal afstand moeten doen van het handelen op basis van persoonlijke inschatting. Artsen en verpleegkundigen zullen samen moeten werken als het gaat om het analyseren van de hulpvraag en het toetsen van de resultaten.

Om de zorg voor familieleden in de praktijk te realiseren is het van belang om deze zorg een duidelijk plaats te geven in het totale zorgproces. Na de opname van de patiënt op de intensive care zou direct, of direct daarna, een intake-gesprek met de familie gevoerd kunnen worden. Met behulp van de familie-gegevens kan de zorg voor de familie gepland, uitgevoerd en getoetst worden. Hierop zal de organisatie van de intensive care moeten worden afgestemd.

Nadat de patiënt is opgenomen op de intensive care zullen verpleegkundigen de gelegenheid moeten nemen en krijgen om familieleden te woord te staan. Naast informatie over de situatie waarin de patiënt verkeert, zal de verpleegkundige de zorgvraag en specifieke behoeftepatronen van de familie moeten analyseren. Hierna kan indien gewenst en noodzakelijk, naast het behandelplan voor de patiënt, een familiezorg-plan worden opgesteld waarin afspraken gemaakt worden met betrekking tot specifieke wensen. Hierbij speelt de flexibiliteit van de organisatie en de verpleegkundige een grote rol. Wanneer familieleden bijvoorbeeld een bijzondere bezoekregeling wensen, kan de situatie ontstaan dat organisatiebelangen belangen van de verpleegkundige onder druk komen te staan. Juist deze belangen pleiten voor de ontwikkeling van een familiezorg-plan waarin belangen van organisatie, verpleegkundigen en familieleden op elkaar worden afgestemd. Niet altijd zal een familie-zorgplan noodzakelijk zijn. Belangrijk is dat verpleegkundigen familieleden tevens leren zien als consument, waarbij een klant-leverancier relatie tot de mogelijkheden gaat behoren. Het familie-zorgplan dient als zodanig op basis van individuele noodzaak te worden ingevoerd en niet in de rij protocollen te belanden.

Bij de ontwikkeling van een familie-zorgplan dienen, naast afstemming van de organisatie, ook de belangen van disciplines die betrokken zijn bij de zorg rondom de patiënt, op elkaar te worden afgestemd. In samenspraak met de behandeld arts zal de verpleegkundige afspraken moeten maken over de interventies die gericht zijn op familieleden. Hierbij moet gedacht worden aan taakverdeling met betrekking tot informatieverstrekking. Hierbij gaat het er niet alleen om wie de informatie geeft maar vooral ook dat deze wordt gegeven en dat de informatie in begrijpelijke taal wordt gegeven. Ook zouden verpleegkundigen niet moeten schromen om informatie te verstrekken op het gebied van de medische behandeling. Niet alleen geven veel familieleden hieraan de voorkeur, ook is het zo dat verpleegkundigen hiervan vaak goed op de hoogte - en beter in staat zijn om informatie in begrijpelijke taal te geven. 


\section{Gericht op opleidings- en bijscholingsprogramma's}

In het voorgaande is reeds aan de orde gesteld dat het verbeteren van de zorg voor familieleden op de intensive care bevorderd kan worden middels een duidelijke taakafbakening door structureel overleg en het geven van feedback. Echter een belangrijke randvoorwaarde voor het slagen van deze aanpak is dat verpleegkundigen daadwerkelijk in staat zijn om behoeften van familieleden te signaleren en op een doeltreffende wijze daarop in gaan.

Deze vaardigheden kunnen ontwikkeld worden binnen de opleiding, respectievelijk bij- en nascholing.

Uitvoering van zorg voor familieleden wordt verondersteld gelegenheid te bieden voor uitbreiding van het verpleegkundig domein en stelt meer eisen aan de opleiding en ervaring van intensive care verpleegkundigen, met alle uitdaging van dien. Het feit dat men te maken heeft met familieleden, wier algemene toekomstbeeld, ten gevolge van de levensbedreigende situatie waarin hun naasten verkeren, onvoorspelbaar is en plotseling kan veranderen, bepaalt in sterke mate de conditie waaronder intensive care verpleegkundigen moeten werken. Waar echter voor gezorgd moet worden is dat intensive care verpleegkundigen leren omgaan met dergelijke omstandigheden en in de opleiding hier goed op voorbereid worden.

De combinatie van zorg voor de patiënt en familieleden op de intensive care vereist zowel aandacht voor instrumenteel-technische vaardigheden als sociaal-emotionele vaardigheden. Een flexibele instelling, met voortdurende afstemming van de manier van begeleiden op de behoeften van familieleden moet gezien worden als een noodzakelijke eis die aan intensive care verpleegkundigen gesteld moet worden.

Een ander punt waaraan opleidings- en bijscholingsprogramma's aandacht zouden moeten besteden is het begeleiden van familieleden die in stresserende situaties verkeren, met andere woorden de door familieleden gehanteerde copingstrategieën. Een sociale steun zoekende aanpak van familieleden leidt tot toename van behoeften. In de opleiding zou verpleegkundigen geleerd moeten worden inzicht te krijgen in copingstrategieën die door familieleden gehanteerd worden en het meest effectief zijn.

Tot slot dienen opleidingen ruime aandacht te besteden aan de daadwerkelijk behoeften van familieleden op de intensive care en het op een gestructureerde wijze opnemen van deze behoeften in opleidingsprogramma's.

\section{Aanbevelingen}

Een mogelijkheid ter stimulering van bovenstaande zou de uitbreiding van een verpleegsysteem zijn, waarin familietoewijzing analoog aan patiëntentoewijzing wordt toegepast. De uitbreiding van verpleegkundige taken door familietoewijzing heeft niet of nauwelijks verhoging van de werkdruk tot gevolg. Wel dient rekening te worden gehouden met het gevaar dat een systeem van familietoewijzing ontaardt in een scala van administratieve taken. Verhoging van kwaliteit van zorg voor familieleden leidt niet tot extreme activiteiten, doch behoort tot de professionele standaard van verpleegkundigen. Door de uitbreiding van een dergelijk systeem hebben verpleegkundigen de mogelijkheid de hen toegewezen familieleden in hun totaliteit te begeleiden en te betrekken bij het zorgverleningsproces van de patiënt. 
Voltooiing van een compleet en afgerond geheel kan in de praktijk een verrijking van de kwaliteit van de verpleegkundige taken betekenen. Eveneens kan verwacht worden dat een betere afstemming van verpleegkundige interventies op behoeften van familieleden leidt tot verhoging van de kwaliteit.

Een goede begeleiding bij het initiëren en implementeren van een familiezorg-systeem is, naast deskundigheidsbevordering door scholing, aan te bevelen. Ook een duidelijke taakafbakening moet gezien worden als een vereiste voor een optimaal systeem voor familiezorg. Belangrijk is hier te weten welke taken, met betrekking tot familiebegeleiding, door de arts worden uitgevoerd en welke door de verpleegkundige. Bevordering van duidelijkheid in taken kan verkregen worden door structureel overleg en het geven van feedback aan elkaar. Dit biedt verpleegkundigen en artsen de gelegenheid tot het uitwisselen van ervaringen en gevoelens ten aanzien van familieleden. Een goed functionerend familiezorg-systeem, waarin door artsen en verpleegkundigen intensief wordt samengewerkt, kan als geëigend middel ter verbetering van familiebegeleiding op de intensive care worden gezien.

Met behulp van familie-gegevens, die de basis vormen voor een familie-zorgplan, kunnen praktisch relevante kenmerken van de patiënt, de organisatie en familie worden gedocumenteerd. Hierbij vormen de resultaten uit onderhavige studie de leidraad. In het familie-zorgplan kunnen afspraken worden vastgelegd en verpleegkundige interventies geformuleerd worden gericht op behoeften van familieleden. De basis voor het familiezorgplan wordt ook hier gevormd door de resultaten uit dit onderzoek.

\section{Verder onderzoek}

Uit onderhavig onderzoek is naar voren gekomen dat er, met betrekking tot behoeften van familieleden van intensive care patiënten, een aantal aspecten is aan te wijzen die samenhangen met sociaal-demografische kenmerken van het familielid, ziektegebonden kenmerken van de patiënt, intensive care gelieerde kenmerken van de organisatie en coping strategieën van het familielid. Een volgende stap zou kunnen zijn dat manipulatie van beïnvloedende kenmerken meer duidelijkheid zou kunnen verschaffen over de samenhang van beïnvloedende kenmerken en behoeften van familieleden. Voorts zou in een dergelijke onderzoekslijn de link naar kwaliteit van zorg voor familieleden en een afbakening en integratie van de rol van de arts op het onderhavige gebied kunnen plaatsvinden. Op basis van dergelijk onderzoek kunnen meer concrete en onderbouwde aanbevelingen voor familie zorgprojecten op de intensive care gedaan worden. In deze studie zijn (relatief) lage Alpha's gevonden in de drie afzonderlijke behoeftecategorieën. Aanbevelenswaardig is gebruikmaking van grote onderzoekspopulaties, zeker wanneer subgroepanalyses worden toegepast.

In deze studie zijn slechts twee deelpopulaties onderzocht. De totale populatie familieleden van intensive care patiënten bestaat echter uit veel meer (mogelijke) deelpopulaties (familieleden van neurochirurgische intensive care patiënten, transplantatiepatiënten of pediatrische patiënten). Het is daarom aan te bevelen studies naar behoeften van familieleden te herhalen voor andere deelpopulaties. 
Een ander aandachtspunt is de onderlinge samenhang tussen beïnvloedende factoren en gehanteerde coping strategieën. Dit is voornamelijk van belang om te kunnen achterhalen wat de oorzaak-gevolg relatie is met betrekking tot behoeften van familieleden.

Nog een stap zou kunnen zijn om onderzoek te doen naar de inschatting van behoeften van familieleden door intensive care verpleegkundigen en artsen. Op deze wijze zou inzicht verkregen kunnen worden in de kwaliteit van familiebegeleiding vanuit het gezichtspunt van de zorgverleners. Wanneer deze resultaten met de resultaten uit onderhavige studie zouden kunnen worden vergeleken, kunnen duidelijke richtlijnen ter verbetering van de zorg voor familieleden verkregen worden.

Tot slot is het van belang dat implicaties zoals de invoering van een familiezorg-systeem getoetst worden op bruikbaarheid en verbetering van familiezorg. Dit zou kunnen plaatsvinden door het onderzoek te herhalen na implementatie van het zorgsysteem en een controlegroep te introduceren waarbij dit systeem (nog) niet is ingevoerd. 



\section{Summary}

The final chapter of this thesis is a summary on the needs of family members of intensive care patients. The four paragraphs describe the reason and theoretical background of this study, research questions and methods, the results and practical implications and finally suggestions for further research.

\section{Reason and theoretical background of this study}

The first reason to start this study was the relative neglect of family members of intensive care patients. In general, patients who are admitted to an intensive care unit are unconscious or not totally conscious and not capable of understanding their medical situation. This in contrast to family members, who are suddenly confronted with the admission of a close family member on an intensive care unit. They are facing a situation of uncertainty and fear. A situation which is threatening and placing family members in a position of (total) dependence. Events on an intensive care unit can be so dramatic that family members often have difficulties coping with the situation. Until recently, there has been a lack off (research-) attention for the needs of family members on the intensive care. Possibly, this has to do with nurses discussing problems that they themselves experience or notice in the care of the patient, with family members. Nurses assume that family members experience and notice the same problems as they do. In recent years this situation has changed which means that there is growing attention for the co-operation between patients and hospital staff. For example, patients are more and more involved in questions concerning their care. Using nursing assessment, care-plans are made by nurses in dialogue with the patient. Family members are hardly involved in this process. However, the assessment phase should also include the needs of family members. In this manner, potential problems can be screened and family members will have the opportunity to make their wishes and expectations known. This way opportunities are developed for nursing interventions directed to family members.

Turbulent developments in health care are the second reason, which effect the care for patients and family members. Continuing policy measures in health care on one side and increasing quality demands on the other side, create a situation wherein it becomes more and more difficult for the nurse to practice her profession. A law passed in 1994, Professional Individuals in Health Care (Beroepen Individuele Gezondheidszorg, 1994) is responsible for the fact that nurses today can be held accountable for the way they treat patients and family members.

The Law for Quality in Health Care Institutions (1996), Law of Medical Treatment Agreement (1995), the Law Client Complaints in Health Care (1995) and the Law of Client Participation in Health Care Institutions (in preparation) lead to a situation where the patient and family can be more critical towards health care personnel. 
The theoretical background of this study are the results of empirical material on one side ( Hampe, 1975; Molter, 1979; McGregor et al., 1981; Yoder \& Jones, 1982; Bozett et al., 1983; Daley, 1984; O'Neill-Norris en Grove, 1986; Mclvor en Thompson, 1988; Dockter et al., 1988; McHale en Bellinger, 1988; Liddle, 1988; Norheim, 1989; Forrester et al, 1990; Chartier \& Coutu-Wakulczyk, 1989; Freichels, 1991; Koller, 1991; Murphy et al., 1992; Farrel en Frost, 1992; Titler \& Walsh, 1992; Henneman et al., 1992; Pender, 1993; Biley et al., 1993; Davis-Martin, 1994; Quinn, et al., 1996; Plowright, 1996; Delva \& Vanoost, 1997; Zazpe et al., 1997), and on the other side the Neuman Systems Model (Neuman, 1995).

In this study general needs, based on empirical material, will be distinguished in (1) the type of needs and (2) the degree (importance) of needs. Daley and Leske used the 46 item Molter's Critical Care Family Needs Inventory (1979), and clustered the need-items in categories based on the type of need. Daley constructed 6 categories, namely (1) the need for relief and anxiety, (2) the need for information, (3) the need to be with the patient, (4) the need to be helpful to the patient, (5) the need for support and ventilation and (6) personal needs. Leske constructed 5 categories, namely (1) support needs, (2) comfort needs, (3) information needs, (4) proximity needs and (5) assurance needs.

The following step is a modification of the model directed towards secondary nursing interventions, by which the three need-categories used in this study are stated. Reformulating the Neuman Systems Model three additional concepts are added, the need for information, support and accessibility. The needs as mentioned in the Neuman Systems Model can be classified under these concepts. Through this study, it was possible to describe the needs of family members of intensive care patients and to make the use of the three concepts acceptable. This study is primarily based on need-categories. The choice for categories is based on findings from empirical material from Daley and Leske.

In conceptualising the need-categories a difference has been made between instrumental directed needs, social -emotional directed needs and structure directed needs. Originally, communication directed needs were considered in a category named the need for communication.

However, factor analysis of the results lead to a preference for three need-categories of family members instead of four. The needs of family members are compiled in three need-categories, they are (1) needs for information, (2) needs for support and (3) needs for accessibility. The need for communication was excluded as a separate category because it is integrated in the three other categories. Apparently, communication is an aspect of the need for (1) information, (2) support and (3) accessibility. Also, based on the internal consistency of the total need list, the need for information, support and accessibility can be combined in a more abstract concept, namely the need for supervision.

The Neuman Systems Model is based on different theories, e.g. the system theory, the stresscoping theory and the prevention theory. In Neuman's model prevention is fundamental because it provides the basis for nursing actions. Neuman divided nursing interventions in three categories (primary, secondary and tertiary preventive interventions). Primary preventive interventions are aimed at health promotion. These interventions take place when stressors are expected or already present but have not yet caused any problems. 
Secondary preventive interventions are directed at patient recovery and are initiated after stressors have caused an imbalance causing health problems. Tertiary preventive interventions are directed at maintaining health and take place during the recovery phase. Starting from the Neuman Systems Model, this study is directed towards secondary preventive interventions involving family members on the intensive care.

Based on the Neuman Systems Model (Neuman, 1995) this study is placing emphasis on the secondary nursing interventions regarding needs of family members of intensive care patients. As can be seen in table 2.2.1, the secondary intervention strategy is directed at "assist family spiritual and psychosocial", which can be classified as "support interventions". Molter, Daley and Leske also describe the need category "need for support".

"Answer questions honestly, family communication, provide assurance regarding treatments/prognosis and update family regularly" are directed at "information interventions". Above mentioned researchers also speak of "need for information".

Although the researchers do not explicitly mention the need of accessibility, Neuman states that "liberal visitation" and "family involvement in care-planning" are important in supplying necessary needs.

\section{Research questions and methods}

Based on the first two chapters of this thesis the conclusion can be drawn that the application of the results found by Leske (categorising of need-items and the influence of socialdemographic and specific factors) within the intervention-scheme of Neuman and the Coping Theory of Lazarus form an appropriate starting point for completing the theoretical framework of this study.

Besides this a number of additions can improve the usefulness of the model. Categorising the needs in need-categories and the addition of several specific factors (social-demographic factors, intensive care related factors, illness related factors and coping factors) is based on theoretical considerations and the specific characteristics of the intensive care.

Research model

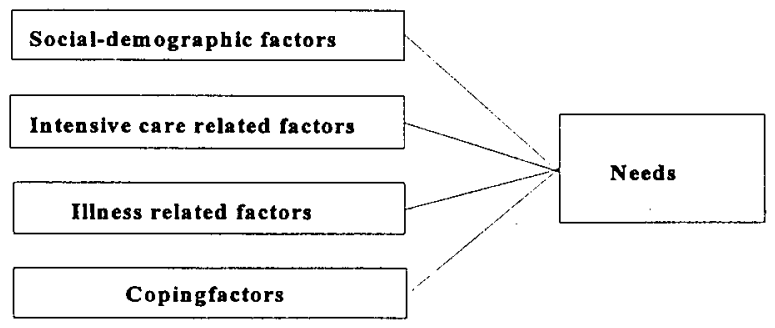




\section{Research questions}

To answer the research questions an explanatory approach with open questions was chosen. Several questions are distracted from the research model. They are the main questions of this research.

\section{Main questions}

\section{Which needs do family members of intensive care patients have?}

Based on literature review it is expected that family members of intensive care patients have a need for information, support and accessibility. Although in general, many researchers have studied needs on an item-level and the fact that Neuman in her intervention-scheme only mentions a few needs, it can be concluded that, based on literature and this study, needs of family members can be categorised in these three different areas. As a consequence of the argumentation given above, this study is aimed at the three categories: need for information, support and accessibility. Although none of the above mentioned researchers studied the general category "need for supervision", where supervision is seen as a sum of the three categories This study will include the category need for supervision.

Beside the importance of the needs of family members on the intensive care, it can also be important which member of the intensive care staff will provide for these needs to the family members. Few researchers studied this subject (Molter, 1979; Daley, 1984), and limited the choice of the intensive care staff to either the doctor or the nurse. Of greater importance are the questions if needs are provided for on the intensive care and if so by which health care professional. Only a few researchers studied these two questions (Quin et al., 1996; Zazpe et al., 1997). But they only measured satisfaction in relation to the need-items. None of the researchers mentioned the possibility of social desirable answers from respondents.

This study is not only directed at needs of family members, but also on who should provide for these needs, are needs provided for and who provided for these needs. Especially the last questions will give insight in the need for family supervision by the nurse or other members of the intensive care staff and the quality of family supervision on the intensive care.

\section{What is the effect of independent and specific factors on family member's needs?}

Several studies (chapter 2) revealed that social-demograhic factors such as age, sex and the relation of the family member to the patient can influence the needs of family members on the intensive care. According to these studies illness-related factors such as earlier experiences with the intensive care, admission indication and the patient's diagnosis also influence the needs of family members. The influence of intensive care related factors such as a waiting list before admission or that a planned admission is postponed have not been studied yet. In this study intensive care related factors are assumed to be of influence.

Finally, it is expected that the coping behaviour of family members influence their needs. 
Despite the fact that many studies have been done concerning coping behaviour, only one study was found looking at the coping behaviour of family members of heart transplant patients waiting for a donor heart (Nolan et al., 1992). In general, most studies place emphasis on the relation between life-events and coping style (Feij et al., 1990). For above mentioned reasons the effect of independent and specific factors on the needs of family members will be part of this study.

\section{Methods}

\section{Research population}

The study involved four intensive care units from two hospitals. A total of 229 family members were asked to participate in this study. In the presence of one of the researchers, the questionnaire was explained to the family member. Face-to-face interviews were used. After the researcher posed a question and the family member had read the question the answer was noted on the questionnaire.

\section{Response}

The total response was $90 \%$ (table 4.4). The total response group consisted of 106 family members of general intensive care patients and 100 family members of intensive care patients who underwent heart surgery.

\section{Method}

To measure the different variables from the research model, oral and written questionnaires were used. The questionnaire contained two scales, namely the need-inventory and a copingscale. Besides these scales some general questions were asked concerning social-demographic variables. The interviews took place between October 1992 and May 1993. Interviews were held at different days of the week. On each interview-day an inventory was made of the number of patients who were admitted to the intensive care less than 72 hours. During visiting hours the family members of these patients were asked to participate in the study. A brief explanation was given concerning the goal of the study, and voluntary participation and anonymity were discussed. Finally, the interview procedure was explained.

After the explanation the family member was asked to participate in the study. If the family member wanted to participate, the questionnaire would either be completed immediately, or an appointment was made for the following day (but only if the patient's admission did not exceed the 72 hours). The interviews were completed in a room made especially available during the research period. The researcher asked the questions, if necessary with a short explanation. Answers were recorded at the questionnaire. The family member completed the shortened version of the Utrecht Coping Scale (Janssen et al., in preparation) themselves. The average interview time was 45 minutes.

The researcher and three graduate students (Nursing Science, University Maastricht) held the interviews. To prevent interviewer bias criteria were formulated concerning the procedure to be followed during the interview and several practice sessions were held. Further, two interviewers, who took turns in interviewing and observing, interviewed the first few family members. 
After the oral interview, the family member was asked to complete the coping-scale individually. Family members were free in the choice of the point of time they wanted to complete the interview.

For the analysis of the needs of family members of intensive care patients a differentiation was made between patients undergoing heart surgery and general intensive care patients. $\chi 2$ test were used to find differences between these two groups. To analyse the influence of social-demographic factors, intensive care related factors, illness-related factors and coping factors on the needs of family members both $\chi^{2}$ test and t-test were used. Finally, through analysing the different aspects of the need-inventory, specific groups of family members were compiled for the different need categories. This was done to develop family profiles relevant for practice.

\section{Results}

\section{Family members of heart surgery patients versus family members of general intensive care patients.}

In this study no difference was found between the need of family members of heart operation patients and family members of general intensive care patients. The need for accessibility to the intensive care proved to be the most important need of family members (mean 3.5), followed by the need for information (mean 2.9).

Least important need was the need for support (mean 2.4). The need for supervision, which is compiled from the three previously mentioned categories, has a mean score of 2.9 .

Family members of heart surgery patients are more frequently confronted with waiting lists and postponement of admission then family members of general intensive care patient. Family members of heart surgery patients were more frequently interviewed within the first 48 hours after admission of the patient to the intensive care then family members of general intensive care patients. From the group of general intensive care patients more patients were admitted to the intensive care for a longer period of time which meant that more family members could be interviewed on the third day of admission. Planned admissions are more seen in the group of heart surgery patients than in the group of general intensive care patients. General intensive care patients are more often mechanically ventilated. Family members of general intensive care patients as well as nurses evaluate the situation of these patients as more life threatening then family members of heart surgery patients do. Both response groups evaluate the situation of their family members as more life threatening than nurses do.

The mean score on the coping sub-scale 'seeking social support' is significantly higher in the group family members of general intensive care patients (2.5) than in the group family members of heart surgery patients (2.2). No differences between the respondents were found in relation to the coping sub-scales 'action directed behaviour', 'awaiting and avoiding' and 'palliative behaviour'.

Finally, logistic regressions were performed with the need for information, support, accessibility and supervision as independent variables. Two profiles were constructed, based on the logistic regressions, one concerning the family members of heart surgery patients 
(Hearts) and one concerning the family members of general intensive care patients (General). The Hearts profile includes family members of a patient who has been on a waiting list before admission, who is not mechanically ventilated, who does not live in the province Utrecht or Gelderland and seeks relatively little social support. Of the 99 family members who meet these characteristics $75 \%$ is a family member of a heart surgery patient. The General profile, which is the contrast of the Hearts profile, includes 106 family members of general intensive care patients of whom $71 \%$ do meet these contrary characteristics. From the 205 family members $73 \%$ is correctly placed in the model.

\section{Influencing factors}

Needs of family members of intensive care patients are influenced by different independent and specific factors. These influences are seen in both the total research group and the two sub-groups. A total of 15 factors were found to be of influence, 5 of these factors are socialdemographic factors (sex, religion, age, relationship and previous experience with the intensive care). Three factors were intensive care related (unpleasant experience during the intensive care period, waiting list before admission and postponement of admission), 3 illness-related factors (mechanical ventilation, frequency of admission and estimated life threatening situation) and 4 coping styles (action directed behaviour, seeking social support, awaiting and avoiding and palliative behaviour).

Again, logistic regressions were performed with the need categories as independent variables. All 15 influencing factors were included in the analyses. Because the sex of the family member appeared to be an important factor, logistic regressions were performed for both male and female family members. Evidently, the developed profiles can be of great use in the care for family members, in that more specific attention can be given to their needs. The needs of male family members are influenced by an unpleasant experience during the intensive care period, the acute admission of the patient and his coping behaviour. The needs of female family members are influenced by age, waiting list before admission, familiarity with the intensive care, postponement of admission, frequency of admission of the patient, an unpleasant experience during the intensive care period and coping behaviour.

\section{Typology of the need-items}

Using the individual need-items three types of family members could be developed. The typology of family members is applied on the individual need-items within the different need categories. Only those need-items consisting of four questions (a) do you find it important, (b) who do you think should provide for this need, (c) has the need been provided for and (d) who provided the need) were included in the typology.

In this way, an attempt was made to classify respondents into types of family members taking into account that the answers to the sub-questions within one individual need-item makes the type legitimate.

Where doctors and hostesses play a relatively small part in providing for the needs of family members, nurses are playing a larger part. In the area of the need for support $58 \%$ of the nurses did provided for the support wanted. In the case of the need for information $59 \%$ of the nurses gave the information wanted. 
Nurses on intensive care units should reflect their role as being a supporter as well as being an informant to the family members of intensive care patients.

The relation of the family member to the patient, the age of the family member and the residence of the family member influence the typology of the family. The intensive care related factors waiting before admission of the patient and an unpleasant experience during the intensive care period influence the typology of family members, just as the illness related factors frequency of admission of the patient, mechanical ventilation and the emergency of the admission. In case of the coping styles an influence of all four coping styles was found on the typology.

Concerning the presence of an intensive care staff member during the first visit to the patient family members prefer the presence of the nurse. This is similar to the preference family members have when they have questions concerning the medical treatment. Another member of the intensive care staff is preferred as a contact. Family members on the intensive care prefer support from nurses just as information about a transfer to another unit or hospital. Explanation about medical equipment used in the care of the patient should also come from the nurse, according to the family members. A remarkable finding is that family members with higher scores on the coping styles 'action directed behaviour' and 'seeking social support' in general give preference to nurses. Family members with higher scores on the coping style 'waiting and avoiding' prefer other intensive care staff members. In a few cases family members with these coping styles do not prefer to get information or support.

The factors as discussed in this chapter do not have an influence on the need "being able to talk about experiences and feelings on the intensive care". Possibly this is related to the fact that the majority of the family members did not express this need.

\section{Implications for practice}

From the results of this study implications for practice can be formulated for future nursing management concerning the family members of intensive care patients. When the care for family members on the intensive care will be improved, then there are several implications for practice stemming from this study. The implications for practice can be divided in:

* implications for nursing diagnosis and interventions in regard to family members on the intensive care

* implications for (postgraduate) education programmes aimed at the care for family members on the intensive care

\section{Implications for practice directed at nursing diagnosis and interventions}

In general family members of intensive care patients have a great need for information and accessibility. To a lesser degree, but none the less important, is the need for support on the intensive care. Besides this there are several factors that can be determining to the needs of family members and thus can be subjects to interventions. Nurses will have to develop and use working methods and procedures that insure positive reactions from family members. 
Genuine interest and responsibility must come from a professional attitude of nurses. To achieve nursing interventions for family members in a professional way, the nurse will need a theoretical framework to give these interventions stature. Nurses must gain insight in the situation of family members and they should be able to analyse and test the need for help of family members, using the influencing factors. In this manner, professional care for family members will replace (nursing) intuition based practice.

Even though family members attribute a dominant position to nurses, it can also be expected that doctors operate professionally, in case of medical information. The doctor is obligated by law to give family members necessary information in a language understood by the family members. Doctors and nurses must co-operate in regard to analysing the need for care and the testing of results.

To accomplish the care for family members it is important to place it explicitly within the total care process. An intake with the family could take place (almost) immediately after admission of the patient. Using the family-information the care for the family could be planned, executed and evaluated. This has consequences for the organisation of the intensive care.

After the patient has been admitted to the intensive care the nurse should take time to talk to the family. Besides information on the situation of the patient, the nurse must analyse the care needs and specific need-patterns of the family members. If necessary a family care-plan can be made, in addition to the patients care-plan, to settle specific needs. For example, if family members want to make special visiting arrangements, the situation could occur, that the interest of the organisation or the nurse is stressed. Especially these interests can be an argument to develop family care-plans. With a family care-plan the interest of the organisation, nurses and family can be balanced. A family care-plan is not always necessary. It is important that nurses learn to see the family members as consumers, it then becomes possible to create a consumer - supplier relation. The family care-plan should be made if there is an individual need and should not be treated as a protocol.

In developing a family care-plan the interests of all disciplines involved in the care for the patient must be made concordant. Doctor and nurse should agree on the interventions for family members. Task-division should be discussed in the case of providing information. It is not only important that the information is given, but the information should be given in a language understood by the family member. Nurses should not hesitate to provide information regarding the medical treatment. Not only do family members have a preference for the nurse to provide information, nurses are also well informed and often more able to give the information in a language understood by the family members.

\section{Implications for (postgraduate) education programmes}

Previously is has been stated that improving the care for family members on the intensive care can be promoted by task-division reached in structural consultations and feedback. It is crucial for the success of this approach that nurses are capable to signal the needs of family members and to deal with these needs in an effective way. These skills can be developed within a (postgraduate) education programme. 
Nursing interventions aimed at family members are supposed to extent the nursing domain and put a greater demand on education and experience of the intensive care nurse including all possible challenges. The fact that one has to deal with family members, whose prospects are unpredictable and changeable, because of the life-threatening situation of their family member, strongly influences the conditions under which intensive care nurses must work. It is important that nurses learn to handle such situations and have been prepared for such events in their education programme.

The combination of care for patients and family members requires both technical and socialemotional skills. A flexible attitude towards supervision of the family members must be seen as a necessary criterion in dealing with the needs of family members.

Coping-strategies of family members should also be part of the (postgraduate) education programmes. For example, family members with a dominant coping strategy 'seeking social support' do have more needs then family members with other dominant coping-strategies. Nurses must learn to gain insight in coping-strategies of family members and which coping strategies are effective.

Finally, education programmes should pay attention to the actual needs of family members on the intensive care and should incorporate this subject in the educational programmes structurally.

\section{Suggestions for practice}

A possibility to stimulate the above mentioned is the extension of the nursing system, where family assignment is parallel to patient assignment. Extension of the nursing tasks with family assignment does not necessarily mean an increase in workload. It has to be taken into account that a system of family assignment does not imply an increase in administrative duties. Increasing the quality of care for family members does not lead to extreme activities but is part of the professional standard of nursing. The extension of the system creates possibilities for nurses to supervise the family members assigned to them and to involve family members in the care of the patient. The completion of a total and all-round care programme in the clinical practice can mean enrichment in the quality of the nursing tasks. Also, it can be expected that a better planning of nursing interventions towards the needs of family members lead to a higher quality of care.

Initiation and implementation of a family care-system with professional guidance is essential next to education and clear job-division. It is important to know which tasks the doctor performs or which tasks does the nurse in relation to family supervision perform. Constructive discussion and feedback by both groups can improve clarity in responsibility of assignments. This gives doctors and nurses the opportunity to exchange experiences and feelings regarding the family members. A well functioning family care-system, where doctors and nurses work together, can be seen as the sole means of improving family supervision on the intensive care.

Using family-data, the base of the family care-plan, practical and relevant characteristics of the patient, the organisation and family can be documented. 
Results of this study can be used as a guideline. Appointments and nursing interventions can be documented in the family care-plan. The results of this study can function as the base for the family care-plan.

\section{Suggestions for research}

This study showed that social-demographic factors of the family members, illness related factors of the patient, intensive care related factors of the organisation and coping behaviour of the family member influence the needs of family members of intensive care patients. Interventions concerning these factors could be a next step in clarifying the relation between these factors and the needs of family members. Furthermore it would be possible to examine the quality of care for family members as well as to further define the role of the doctor regarding the needs of family members. Based on such research more concrete recommendations can be given towards family care projects in the intensive care. In this study relatively low Cronbach alphas were found for the three need-categories. Larger researchpopulations should be used, especially when subgroup-analyses are to be performed.

The population of this study involved two different groups of family members of intensive care patients. It is recommended that other populations of family members of intensive care patients are studied (for example, family members of neuro-surgical intensive care patients, transplant patients and paediatric patients.

Another point of attention is the relationship between the influencing factors and used coping strategies. The main importance is to study the causality of coping strategies in relation to the needs of family members.

Another possibility for research could be to let doctors and nurses estimate the needs of family members. This way insight could be gained in the quality of family care from the viewpoint of the intensive care staff. When the results of such a study were to be compared to the results of this study, guidelines to improve the care of family members could be developed.

Finally, it is important that new implementations like a family care-system are evaluated on usefulness and improvement of family care. Repeating this study after the implementation of a family care-system using a control group is a possibility. 


\section{LITERATUUR}

Alpen, M.A., Halm, M.A., Family needs: an annotated bibliography, Critical Care Nurse, volume 12 , number 2, 40-50, February, 1992

Arets, J., Vaessen, J., Professionele verpleegkunde, handboek voor verpleegkundigen, deel 1, Spruyt Van Mantgem \& De Does bv., Leiden, 1993.

Bal, R.M., Health deviation and daily functioning in elderly rheumatoid arthritis patients, Proefschrift, Rijksuniversiteit Limburg, Maastricht, 1992.

Bernstein, L.P., Family centered care of the critically ill neurologic patient, Advances in Neurologic Care, 2 (1), 41-9, 1990.

Biley, F.C., Millar, B.J., Wilson, A.M., Issues in intensive care visiting, Intensive and Critical Care Nursing, 9, 75-81, 1993.

Boomen, van den, I.J.H.C., Vlaskamp, A.A.C., Onder voorbehoud; De Wet BIG, Ministerie van Volksgezondheid, Welzijn en Sport, Rijswijk, september 1996.

Bouman C.C., Identifying priority concerns of families of ICU patients, Dimensions of Critical Care Nursing, 3, 313-319, 1984.

Bouman, C.C., Self-perceived needs of family members of critically ill patients, Heart \& Lung, 13, 294-295, 1984.

Boumans, N.P.G., Het werk van verpleegkundigen in algemene ziekenhuizen: een onderzoek naar werkaspecten en hun invloed op verpleegkundigen. Proefschrift, Rijksuniversiteit Limburg, Maastricht, 1990.

Bouter, L.M., van Dongen, M.C.J.M., Epidemiologisch onderzoek: opzet en interpretatie, Utrecht/Antwerpen: Bohn, Scheltema \& Holkema, 1988.

Bozett, F.W., Gibbons, R., The nursing Management of families in the critical care setting, Critical Care Update, 22-27, February, 1983.

Breu, C., Dracup, K., Helping the spouses of critically ill patients, American Journal of Nursing, $78,50-53,1978$.

Breukelen, G. van, Talsma, P., Analyse van vragenlijsten, Rijksuniversiteit Limburg, Maastricht, 1993.

Brugge ter, C.H., Jong de, L.I., De behoefien van familieleden van intensive care patienten, een literatuurstudie, Rijksuniversiteit Limburg, Maastricht, 1993.

Brugge ter, C.H., Jong de, L.I., De levensbedreiging van intensive care patiënten ingeschat door familieleden, Afstudeerscriptie, Rijksuniversiteit Limburg, Maastricht, 1994.

Bruggen, H. van der, Verpleegkundige theorievorming in Nederland, Verpleegkunde Modulair, Dwingeloo, Kavanah, 1993. 
Chartier, L., Coutu-Wakulczyk, G., Families in ICU: their needs and anxiety level, Intensive Care Nursing, 5, 11-18, 1989.

Coutu-Wakulczyk, G., Chartier, L., French validation of the critical care family needs inventory, Heart \& Lung, vol. 19, no. 2, march 1990.

Curry, S., Identifying family needs and stresses in the intensive care unit, British Journal of Nursing, volume 4, number 1, 15-19, January, 1995.

van Dale, Groot Woordenboek der Nederlandse Taal, van Dale Lexicografie, Utrecht/Antwerpen, 1989.

van Dale, Groot Woordenboek Engels/Nederlands \& Nederlands/Engels, van Dale Lexicografie, Utrecht/Antwerpen, 1989.

Daley, L., The perceived immediate needs of families with relatives in the intensive care setting, Unpublished Thesis, The Ohio State University School of Nursing, 1980.

Daley, L., The perceived immediate needs of families with relatives in the intensive care setting, Heart \& Lung, volume 13, number 3, 231-237, May, 1984.

Daly, K., Kleinpell, R.M., Lawinger, S., Casey, G., The effect of two nursing interventions on families of ICU patients, Clinical Nursing Research, volume 3, number 4, 414-422, November, 1994.

Daniels, L., Rose, A., Wall, E., Rees, C., Road to recovery, Intensive Care Nursing, 5, 19-24, 1989.

Davidhizar, R., Critique of the health-belief model, Journal of Advanced Nursing, 8, 467-472, 1983.

Davis-Martin, S., Perceived needs of families of long-term critical care patients: a brief report, Heart \& Lung, volume 23, number 6, 515-518, December, 1994.

Delva, D., Vanoost, S., Psychosociale opvang van familieleden op de intensive care, Kritiek, Tijdschrift voor intensive care-medewerkers, nr 2, jaargang 15, 3-11, juni, 1997.

Derham, C., An evaluation of the preoperativee information given to patients by intensive care nurses, Intensive Care Nursing, 7, 80-85, 1991.

Dockter, B., Black, D.R., Hovell, M.F., Engleberg, D., Amick, T., Neimier, D., Sheets, N., Families and Intensive Care Nurses: Comparison of Perceptions, Patient Education and Counseling, 12, 29-36, 1988.

Dracup, K., Challenges in critical care nursing: Helping patients and families cope, Critical Care Nursing, supplement, August, 1993.

Emans, B., Interviewen, Theorie, techniek en training, Wolters-Noordhoff, Groningen, 1986.

Engli, M., Kirsivali-Farmer, K., Needs of family members of critically ill patients with and without acute brain injury, Journal of Neuroscience Nursing, volume 25, number 2, April, 1993. 
Farrel, F., Frost, Ch., The most important needs of parents of critically ill children: parents' perceptions, Intensive and Critical Care Nursing, 8, 130-139, 1992.

Feij, J.A., Kampen van, D., Doorn, C.D., Resing, W.C.M., Berg van den, P.T., De relatie tussen ingrijpende gebeurtenissen, copingstijlen en klachten, Gedrag en gezondheid, 182-196, 18, 4/5, 1990.

Forrester, D.A., Murphy, P.A., Price, D.M., Monaghan, J.F., Critical care family needs: Nursefamily member confederate pairs, Heart \& Lung, volume 19, number 6, 655-661, November, 1990.

Foss, K.R., Tenholder, M.F., Expectations and needs of persons with family members in an intensive care unit as opposed to a general ward, Southern Medical Journal, volume 86, number 4, 380-384, April, 1993.

Frederiks, C.M.A., En nu naar bed! Inaugurele rede, katholieke Universiteit Nijmegen, Nijmegen, 1997.

Frederiks, C.M.A., Over verpleegkunde en verpleegkunst, TVZ Tijdschrift voor verpleegkundigen nr 1/2, 5-8, 1997.

Freichels, T.A., Needs of family members of patients in the intensive care unit over time, Critical Care Nursing Quarterly, volume 14, number 3, 16-29, November, 1991.

Furda, J., Werk, persoon en welzijn. Een toetsing van het Job Demand-Control model, Proefschrift, Universiteit Utrecht, Utrecht, 1995.

Gardner , D., Steward, N., Staff involvement with familiels of patients in critical-care units, Heart \& Lung, vol. 7, no.1, 105-110, Januari -Februari, 1978.

Geary, M.C., Supporting Family Coping, Supervisor Nurse, 52-59, March, 1979.

Grandstrom, D.M., Families in Critical care; what do they really want? Focus on Critical Care, volume 17, number 1, 9-10, February, 1990.

Guida Brown, D, Glazer, H., Higgings, M., Group intervention: A psychosocial and educational approach to open heart surgery patients and their families. Social Work in Health Care, 47-59, Vol. 9 (2), Winter 1983.

Gulla, J.P., Family assesment and its realtion to hospital care, The American Journal of Hospice and Palliative Care, 30-34, July/August, 1992.

Halm, H.A., Effects of support groups on anxiety of family members during critical illness, Heart \& Lung, volume 19, number 1, 62-71, January, 1990.

Hammond, $\mathbf{F}$., Involving families in care within the intensive care environment: a descriptive survey, Intensive and Critical Care Nursing, 1, 256-264, 1995.

Hampe, S.O., Needs of the grieving spouse in a hospital setting, Nursing Research, volume 24, number 2, 113-120, March/April, 1975.

Harrington, L., Letters to the editor, Heart \& Lung, volume 21, number 2, 199-200, March, 1992. 
Harvey, M.A., Waiting and wanting: helping families in crisis. Critical Care Nurse, june 1993 (13).

Heise, J., Nursing intervention with family of the critically ill patient, Advancing Clinical Care, 24-25, July/August, 1991.

Henneman, E.A., McKenzie, J.B., Dewa, C.S., An evaluation of interventions for meeting the information needs of families of critical care patients, American Journal of Critical Care, volume 1, number 3, 85-93, 1992.

Hickey, M.L., What are the needs of families of critically ill patients, Review of literature, Heart \& Lung, 19, 401-415, 1990.

Hickey, M.L., Leske, J.S., Needs of families of critically ill patients, Critical Care Nursing Clinics of North America, volume 4, number 4, December, 1992.

Huizingh, E., Inleiding SPSS/PC+ en Data Entry, Addison-Wesley Europe BV., 1990.

Hylton Rushton, C., The critical care nurse as patiënt advocate. Critical care nurse, I02-106, juni 1994.

Imbos, T. , Janssen, M., Breukelen, G., Schols, I., Talsma, P., Tan, F., Theunissen, M., Wuts, F., Methodologie \& statistiek voor Gezondheidswetenschappen, inleiding, deel 1,2,3, Faculteit der gezondheidswetenschappen, Rijksuniversiteit Limburg, 1995.

Janssen, M., Personal networks of chronic patients, Proefschrift Rijksuniversiteit Limburg, Maastricht, 1992.

Janssen, M., Bal, RM., Komproe, I., Philipsen, H., Furda, J., Evaluatie van de 15-item versie van de Utrechtse Coping Lijst, artikel in voorbereiding.

Johnson, R.R., Elementary Statistics, 6th ed., PWS-Kent Publishing Company, Boston, 1992.

Jong, J.H.J. de, Kerstens, J.A.M., Salentijn, C., HBO Basisboek 1, inleiding in de verpleegkunde, 2de druk. Bohn, Stafleu, van Loghum, 1992.

Katele, S., Family needs and nursing responses to critically ill patients [letter], Heart and Lung, volume 20, (5 Pt 1), 531, September, 1991.

Kedzierski, J. Th., Vlemmix, M.C., Kwaliteit en beheer, instrumenten voor de manager in de zorg, Bohn Stafleu Van Loghum, Houten/Diemen, 1995.

Kleinbaum, D.G., Logistic regression and Survival Analysis, University of North Carolina at Chapel Hill, 1989.

Kleinpell, R.M., Powers, M.J., Needs of family members of intensive care unit patients, Applied Nursing Research, volume 5, number 1, 2-8, February, 1992.

Knippenberg, A. van, Siero, F., Multi variate analyse, beknopte inleiding en toepassingen, Bohn, Stafleu, van Loghum, Houten/Zaventem, 1993.

Koller, P.A., Family needs and coping strategies during illness crisis, AACN Clinical Issues, volume 2, number 2, 338-345, May, 1991. 
Kupst, M.J., Family coping, supportive and obstructive factors, Cancer supplement, volume 71, number 10, 3337-3341, May, 1993.

Lazarus, R.S., Psychological stress and the coping proces. New York: McGraw-Hill, 1966.

Lazarus, R.S., Averill, J.R., \& Opton, E.M., jr. Psychology of coping: issues of research and assesment. In G.V. Coelho, D.A. Hamburg \& J.E. Adams (Eds.), Coping and adaption. New York: Basic Books (1974).

Lazarus, R.S., Folkman, S., Stress, Appraisal and coping, New York, Springer Publishing Company, 1984.

Leske, J.S., Needs of relatives of critically ill patients: a follow-up, Heart \& Lung, 15, 189-193, 1986.

Leske, J.S., Selected psychometric proporties of the Critical Care Family Needs Inventory (Dissertation), Milwaukee, University of Wisconsin, Milwaukee, 1988.

Leske, J.S., Family-centered Critical Care: an interview with Nancy C. Molter, AACN Clinical Issues, volume 2, number 2, 185-187, May, 1991.

Leske, J.S., Overview of family needs after critical illness: from assessment to intervention, AACN, Clinical Issues, Critical Care Nursing, volume 2, number 2, 220-229, May, 1991.

Leske, J.S., Internal psychometric properties of the Critical Care Family Needs Inventory, Heart \& Lung, volume 20, number 3, 236-244, May, 1991.

Leske, J.S., Comparison ratings of need importance after critical illness from family members with varied demographic characteristics, Critical Care Nursing Clinics of North America, volume 4, number 4, December, 1992.

Leske, J.S., Needs of adult family members after critical illness: prescriptions for interventions, Critical Care Nursing Clinics of North America, volume 4, number 4, 587-596, December, 1992.

Lewandowski, L.A., Nursing grand rounds, The Journal of Cardiovasculair Nursing, volume 9, number 1, 54-60, October, 1994.

Liddle, K., Reaching out...To meet the needs of relatives in intensive care units, Intensive Care Nursing, 4, 146-159, 1988.

Lodder-Prevo, Ph., Verslag ziekteproces echtgenoot, Heerlen, oktober, 1991.

Lopez-Fagin, L., Critical Care Family Needs Inventory: A cognitive Research Utilization Approach, Critical Care Nurse, volume 15, number 4, 21-26, August, 1995.

Macey, B.A., Bouman, C.C., An evaluation of validity, reliability and readability of the Critical Care Family Needs Inventory, Heart \& Lung, volume 20, number 4, 398-403, July, 1991.

Mathis, M., Personal needs of family members of critically ill patients with and without brain injury, Journal of Neuro-surgical Nursing, 16, 36-44, 1984.

Maxton, J.C., Old habits die hard: changing paediatric nurses' perceptions of families in ICU, Intensive and Critical care Nursing, 13,14-150, 1997. 
McCormac Bueno, M., Kendall Sengin, K., The neuman Systems Model for critical care nursing, a framework for practice, The Neuman Systems Model, 1995.

McGaughey, J., Harrisson, S., Understanding the pre-operative information needs of patients and their relatives in intensive care units, Intensive \& Critical Care Nursing, volume 10, number 3, 186-194, September, 1994.

McGaughey, J., Harrisson, S., Developing an information booklet to meet the needs of intensive care patients and relatives, Intensive \& Critical Care Nursing, volume 10, number 4, 271-277, December, 1994.

McGregor, E.A., Fuller, C., Lee, M., Care and support for relatives in the I.T.U., Nursing Times, 1477-1478, August, 1981.

McHaffie, H.E., Coping een wezenlijk onderdeel van verplegen. Verpleegkundig perspectief, 5062, 1993-4.

McHale, D.J., Bellinger, A., Need satisfaction levels of family members of critical care patients and accuracy of nurses' perceptions, Heart \& Lung, volume 17, number 4, 447-453, July, 1988.

McIvor, D., Thompson, F.J., The self-perceived needs of family members with a relative in the intensive care unit (ICU), Intensive Care Nursing, 4, 139-145, 1988.

Molter, N.C., Needs of relatives of critically ill patients, In: Ward, M., Lindeman, C., eds., Instruments for measuring nursing practice and other health care variables. Hyattsville, Maryland: US Department of Health, Education and Welfare, 2, 741-742, 1979.

Molter, N.C., Captain, A.N.C., Needs of relatives of critically ill patients: a descriptive study, Heart \& Lung, volume 8, number 2, 332-339, March-April, 1979.

Molter, N.C., Leske J.S., Critical Care Family Needs Inventory. Copyright 1983. Available from author.

Momat, A., \& Lazarus, R. S., Stress and Coping: an anthology. New York: Colombia University Press, 1977.

Moser, D.K., Dracup, K.A., Marsden, C., Needs of recovering cardiac patients and their spouses: compared views, International Journal of Nursing Studies, volume 30, number 2, 105-114, 1993.

Murphy, P.A., Forrester, D.A., Price, D.M., Monagham, J.F.,Empathy of intensive care nurses and critical care family needs assessment, Heart \& Lung, volume 21, number 1, 25-29, January, 1992.

Murray, P.J., Rehabilitation information and health beliefs in the post-coronary patiënt: do we meet their information needs? Journal of Advanced Nursing, 686-693, 1989, 14.

Nederlandse Vereniging voor Intensive care, Intensive Care voorzieningen in Nederlandse Ziekenhuizen, 1987.

Neuman, B.M., The Neuman Systems Model, -3rd ed.- Appleton \& Lange, Norwalk, Connecticut, 1995. 
Nolan, M.T., Cupples, S.A., Brown, M.M. Pierce, L., Lepley, D., Ohler, L., Perceived stress and coping strategies among families of cardiac transplant candidates during the organ waiting period, Heart \& Lung, volume 21, number 6, November/December, 1992.

Noordhuis, J.R., Roofthooft, S.M.L., De behoeften van familieleden van intensive care patiënten, instrumentontwikkeling, Afstudeerscriptie, Rijksuniversiteit Limburg, Maastricht, 1991.

Norheim, C., Family needs of patients having coronary artery bypass graft surgery during the intraoperative period, Heart \& Lung, volume 18, number 6, 622-626, November, 1989.

Nonusis, M.J./SPSS Inc., SPSS/PC+, Professional Statistics, Version 5.0, SPSS Inc., Chicago, 1992.

Norusis, M.J./SPSS Inc., SPSS/PC+, Advanced Statistics, Version 5.0, SPSS Inc., Chicago, 1992.

O'Neill-Norris, L.O., Grove, S.K., Investigation of selected psychosocial needs of family members of critically ill adult patients, Heart \& Lung, 15, 194-199, 1986.

O'Malley, P., Anderson, B., Siewe, S., Deane, D., Keefer, N., Critical care nurse perceptions of family needs, Heart \& Lung, volume 20, number 2, 189-201, March, 1991.

Peirce, A.G., Wright, F., Fulmer, T.T., Needs of the family during critical illness of elderly patients, Critical Care Nursing Clinics of North America, volume 4, number 4, 597-606, December, 1992.

Pender, S.B., Critical care unit family support sessions: using postvention principles in a medical setting, Crisis, volume 14, number 1, 8-9, 1993.

Plowright, C.I., Revisiting visiting in intensive therapy units: Intensive and Critical Care Nursing, 12, 231-238, 1996.

Polit, D.F., Hungler, B.P., Nursing research: Principles and Methods, 4th ed., Philidelphia: Lippincot Company, 1991.

Poole, E.L., The visiting needs of critically ill patients and their families, Journal of PostAnesthesia Nursing, volume 7, number 6, 377-386, 1992.

Price, D.M., Forrester, D.A., Murphy, P.A., Monaghan, J.F., Critical care family needs in an urban teaching medical center, Heart \& Lung, volume 20, number 2, 183-188, March, 1991.

Quinn, S., Redmond, K., Begley, C., The needs of relatives visiting adult critical care units as perceived by relatives and nurses. Part 1, Intensive and Critical Care Nursing, 12, 168-172, 1996.

Quinn, S., Redmond, K., Begley, C., The needs of relatives visiting adult critical care units as perceived by relatives and nurses. Part 2, Intensive and Critical Care Nursing, 12, 239-245, 1996.

Regeling opleiding aantekening intensive care verpleging, 1994, (Staatscourant. 253).

Reider, J.A., The relationship of family needs satisfaction and family coping strategies to family adjustment during the critical illness of a family member, Dissertation, Washington, DC, 1989.

Reinsma, R. Betrokkenheid bij patiènt en familie: hoe werkt een afdeling patientenbetrekkingen? Cordiaal, 21-24, maart 1994. 
Rodgers, C.D., Needs of relatives of cardiac surgery patients during the critical care phase, Focus on Critical Care, volume 10, number 5, 50-55, 1983.

Rodgers, B.L., The intensity of waiting: life outside the intensive care unit, Focus on Critical Care, volume 17, number 4, 325-329, August, 1990.

Rukholm, E., Bailey, P., Coutu-Wakulczyk. G., Bailey, W.B., Needs and anxiety levels in relatives of intensive care unit patients. Journal of Advanced Nursing, 16, 920-928, 1991.

Rukholm, E.E., Bailey, P.H., Coutu-Wakulczyk, G., Anxiety and family needs of the relatives of cardiac medical-surgical ICU patients, Canadian Journal of Cardiovascular Nursing, volume 2, number 4, 15-22, March, 1992.

Santen, van, J., Uw rechten als patient, Serie patientenrecht, Provinciaal patienten/Consumenten Platform Utrecht, 1995.

Schlump-Urquhart, S.R., Families experiencing a traumatic accident: Implications and Nursing management. AACN Clinical Issues, volume 1, number 3, 522-534, November, 1990.

Schreurs, P.J.G., Persoonskenmerken en essentiële hypertensie, Proefschrift, Rijksuniversiteit Limburg, Maastricht, 1987.

Schreurs, P.J.G., van de Willige, G., Brosschot, J.F., Tellegen, B., Graus, G.M.H., De Utrechtse Copinglijst: UCL, Herziene handleiding, Lisse: Swets en Zeitlinger b.v., 1993.

Schwarzer, R., Steun partner helpt patiënt na hartoperatie. NRC Handelsblad, Ad Bergsma, 9 mei, 1996.

Silva, M., Geary, M., Manning, C., Zeccolo, P., Caring for those who wait, Todays OR Nurse, 6 , 26-30, 1984.

Sindram, I.P.C., BIG in zicht, de wet op de beroepen in de individuele gezondheidszorg. Verplegenden en verzorgenden onder de wet BIG. Nieuwe Unie 1991, 1993.

Spatt, L., Ganas, E., Hying, S., Kirsch, E., Koch, M.., Informational needs of families of intensive care unit patients, $Q R B, 12,16-21,1986$.

Stillwell, S.B., Importance of visiting needs as perceived by family members of patients in the intensive care unit, Heart \& Lung, 13, 238-242, 1984.

Swanborn, P.G., Methoden van sociaal-wetenschappelijk onderzoek, Boom, Meppel, Amsterdam, 1987.

Syred, M.E.J., The abdication of the role of health education by hospital nurses, Journal of Advanced Nursing, 6, 27-33, 1981.

Titler, M.G., Cohen, M.Z., Craft, M.J., Impact of adult critical care hospitalization: Perceptions of patients, spouses, children, and nurses, Heart \& Lung, volume 20, number 2, 174-182, March, 1991

Titler, M.G., Walsh, S.M., Visiting critically ill adults, Critical Care Nursing Clinics of North America, volume 4, number 4, December, 623-632, 1992. 
Visser, A. Ph., Angst en patiëntenvoorlichting, In: A. Ph. Visser en W.F.M. Haes (red.)., Angst en gezondheidsvoorlichting en -opvoeding (G.V.O.). Amsterdam, VU-uitgeverij, Hoofdstuk 13, 225-243, 1987.

Warren, N.A., Perceived needs of the family members in the critical care waiting room, Critical Care Nursing Quarterly, volume 16, number 3, 56-63, November, 1993.

Westerlaak, J.M., Kropman, J.A., Collaris, J.W.M., Beroepenlijst en beroepsnivoklassificatie, ITS, 1975.

Wet Klachtrecht, $U w$ klacht over de gezondheidszorg (wet klachtrecht), uitgave van het ministerie van Volksgezondheid, Welzijn en Sport, 1996.

Wilkinson, P., A qualitative study to establish the selfperceived needs of family members of patients in a general intensive care unit, Intensive and Critical Care Nursing, 11, 77-86, 1995.

Yoder, L., Jones, S.L., The family of the emergency room patient as seen through the eyes of the nurse, International Journal of Nursing Studies, volume 19, number 1, 29-36, 1982.

Zazpe, C., Margall, M.A., Otano, C., Perochena, M.P., Asiain, M.C., Meeting needs of family members of critically ill patients in a Spanish intensive care unit, Intensive and Critical Care Nursing, 13, 12-16, 1997. 


\section{Bijlage 1 46-itemlijst Daley (1984) gebaseerd op de CCFNI (Molter, 1979)}

1. To be able to be with my family member in the ICU

2. To be able to stay nearby the ICU

3. To be allowed to visit at any time

4. To have visiting hours start on time

5. To be able to have young children visit

6. To be able to have friends visit

7. To be able to visit my family member accompanied by a relative or a friend

8. To help with the care of my family member

9. To have someone tell me how I can help

10. To be reassured that my family member is doing alright

11. To have the hospital chaplain visit

12. To have other family members nearby

13. To have friens nearby

14. To be able to talk with other people who have family members in the ICU

15. To talk to the same nurse each day

16. To be assured that it is alright to leave the hospital for a while

17. To have a nurse with me at the bedside

18. To talk to someone about my feelings

19. To be accepted by the staff

20. To have a bathroom nearby that I can use

21. To have coffee available

22. To be alone

23. To have a telephone nearby

24. To have the patient in a private room

25. To have food available nearby the unit

26. To have help with financial concerns

27. To have a place to rest while I am staying there

28. To have a place to take care of personal needs

29. To know what is wrong with my family member

30. To have my questions answered

31. To talk to the doctor

32. To talk to the nurse

33. To be informed of any change in the condition of my family member

34. To be called at home every morning

35. To have my questions answered honestly

36. To have explanations given in understandable terms

37. To have several people answer my questions

38. To know the qualifications of the staff members that are caring for the patient

39. To be allowed to call the unit and ask about my family member at any time

40. To know what may be the expected outcome

41. To know what treatments my family member is receiving

42. To be told there is hope

43. To be informed of any change in the condition of my family member

44. To have someone explain the equipment being used with my family member

45. To know if the nurses are giving the best care possible

46. To be told about transfer plans ahead of time 


\section{Bijlage 2a Brief gericht aan de Directie, maatschappen en toestemmingscommissies van de ziekenhuizen}

Onderzoek

03402-92730

3 oktober 1991

Geachte directie,

In 1990 is aan de Rijksuniversiteit Limburg begonnen met de voorbereiding van een onderzoek, dat zich richt op behoeften van familieleden op de intensive care. Dit onderzoek maakt het mogelijk potentiële knelpunten op te sporen en toekomstig beleid te ondersteunen ten aanzien van behoeften van familieleden en doelgerichte opleidings- en bijscholingsprogramma's.

Onder begeleiding van Prof. Dr. H. Philipsen en prof. Dr. A. Van den Bergh-Braam, verbonden aan de vakgroep Medische Sociologie, respectievelijk Verplegingswetenschap, wordt dit promotieonderzoek uitgevoerd door ondergetekende binnen de vakgroep Verplegingswetenschap.

In januari 1992 zou ik willen starten met het hoofdonderzoek, waarin twee ziekenhuizen (het Academisch Ziekenhuis Utrecht en het St. Antonius Ziekenhuis Nieuwegein) betrokken worden. Conform de onderzoeksopzet wordt gepoogd binnen elk ziekenhuis twee intensive care afdelingen te betrekken, te weten: een hartchirurgische intensive care en een algemene intensive care.

Familieleden zal, met behulp van een face-to-face interview methode, gevraagd worden naar hun behoeften op de intensive care. Elk interview zal ongeveer een uur in beslag nemen.

Mijn vraag is of u uw medewerking wilt verlenen aan het onderzoek binnen uw instelling. Ik hoop op uw bereidheid tot een gesprek tussen $\mathrm{u}$ en mij waarin een nadere toelichting op het onderzoek gegeven kan worden. Graag zal ik in de loop van de maand november telefonisch kontakt met $u$ opnemen.

In de hoop van $u$ een positieve reactie te mogen ontvangen, verblijf ik,

hoogachtend,

M.J. Kaljouw

Hoofd Opleidingen

St. Antonius Ziekenhuis Nieuwegein.

Cc Maatschap Heelkunde

Maatschap Thoraxchirurgie

Commissie Toetsing Medische Experimenten 


\section{Bijlage 2b Brief gericht aan hoofdverpleegkundigen en medewerkers van de afdelingen intensive care}

17 oktober 1991

Aan alle betrokkenen,

Zoals jullie bekend is zal ik zal ik mij de komende jaren bezig houden met een promotieonderzoek naar behoeften van familieleden op de intensive care. In 1991 is een vooronderzoek uitgevoerd onder verpleegkundigen met als doel de vragenlijst te toetsen. Mede dankzij die collega's die de vragenlijst hebben ingevuld is deze inmiddels aangepast en klaar voor gebruik.

In januari 1992 zal het onderzoek op de intensive care starten. De gastvrouwen, voor zover aanwezig, informeren de familieleden over het feit dat een onderzoek gaande is en dat medewerking hieraan op volledig vrijwillige basis plaatsvindt. Vervolgens zullen familieleden volstrekt willekeurig worden geselecteerd voor het onderzoek. Er zullen zowel familieleden van hartoperatiepatiënten als familieleden van overige intensive care patiënten in het onderzoek worden betrokken.

In overleg met de leiding van de intensive care zal ik, indien gewenst, regelmatig informatie verstrekken over de stand van zaken. Dit zal plaatsvinden in het werkoverleg. Bij vragen en/of opmerkingen ben ik altijd bereid hierop in te gaan.

In de hoop jullie hiermee voldoende te hebben geïnformeerd, verblijf $i k$,

met vriendelijke groet,

M.J. Kaljouw

Hoofd Opleidingen

Tel. $03402-92730$ of sein 117 


\section{Bijlage 3 Algemene vragenlijst}

1 Wat is de opname indicatie van de patiënt

2 Is de opname gepland

3 Is er sprake geweest van een wachttijd

$4 \quad$ Is de opname uitgesteld geweest

$5 \quad$ Wordt de patiënt mechanisch beademd

6 Betreft het een eerste opname

7 Tijdstip van afname vragenlijst

8 Hoe schat $\mathrm{u}$ de mate van levensbedreiging van de patiënt in

9 Wat is uw geslacht

10 Wat is uw leeftijd

11 Wat is uw relatie tot de patiënt

12 Bent u gelovig

14 Waar woont $\mathrm{u}$

15 Wat is uw beroep

16 Wat is uw hoogst genoten opleiding

17 Bent $\mathrm{u}$ bekend met de intensive care

18 Heeft $\mathrm{u}$ een indrukwekkende ervaring gehad op de intensive care

19 Heeft $u$ een plezierige ervaring gehad op de intensive care

20 Heeft $u$ een onplezierige ervaring gehad op de intensive care 


\section{Bijlage 4 Vertaalde 46-item-lijst van Daley (1984)}

In staat zijn om/of

1 bij mijn familielid te zijn

2 in de buurt van de IC te zijn

3 ieder moment op bezoek te kunnen

4 bezoekuren die op tijd beginnen

$5 \quad$ kinderen op bezoek te laten komen

6 vrienden op bezoek te laten komen

7 iemand mee te mogen nemen op bezoek (vriend/familie)

8 te kunnen helpen met de verzorging van de patiënt

9 iemand hebben die uitlegt hoe ik kan helpen met de verzorging

10 steeds verzekerd worden dat het goed gaat met de patiënt

11 bezoek door een pastoraal werker

12 andere familieleden in de buurt hebben

13 vrienden in de buurt hebben

14 kunnen praten met familieleden die ook een patiënt op de ICU bezoeken

15 iedere dag met dezelfde verpleegkundige kunnen praten

16 gerustgesteld de ICU kunnen verlaten

17 de verpleegkundige bij me hebben aan het bed

18 over mijn gevoelens kunnen praten

19 geaccepteerd voelen door het personeel

20 een badkamer kunnen gebruiken

21 koffie kunnen gebruiken

22 alleen kunnen zijn

23 een telefoon hebben

de patiënt in een kamer alleen hebben

kunnen eten vlakbij de ICU

hulp krijgen bij de financiële zaken

een plaats hebben om te kunnen rusten

een plaats hebben voor persoonlijke verzorging

weten wat er is met de patiënt

mijn vragen beantwoorden

met de dokter kunnen praten

met de verpleegkundige kunnen praten

geïnformeerd worden over veranderingen

iedere morgen gebeld worden

mijn vragen eerlijk beantwoorden

uitleg krijgen in begrijpelijke taal

van verschillende mensen antwoord kunnen krijgen

kwalificaties weten van het personeel

op ieder moment kunnen bellen

weten wat de verwachte prognose is

de behandeling kennen

verteld worden dat er hoop is

geïnformeerd worden over veranderingen in de conditie van de patiënt uitleg krijgen over de apparatuur

zeker weten dat de verpleegkundigen de best mogelijke zorg verlenen

op de hoogte gesteld worden van overplaatsingsplannen 


\section{Bijlage 5 Interviews}

Open interview hoofd intensive care/klachtencommissie.

1. Over hoeveel bedden beschikt de intensive care afdeling

Hoe is de samenstelling van de personele formatie

Welke opleiding hebben de intensive care verpleegkundigen

2. Welke patiëntencategorieën liggen op de intensive care afdeling

Welke patiëntencategorie komt het meest voor

Worden er evenveel mannen als vrouwen opgenomen

3. Hoe worden familieleden van intensive care patiënten opgevangen

4. Is de opvang van familieleden een taak voor de verpleegkundige

Zo niet, voor wie dan wel

Bij welke disciplines liggen welke verantwoordelijkheden met betrekking tot de opvang van familieleden

5. Welke behoeften worden gesignaleerd bij familieleden van intensive care patiënten

6. Zijn er verschillen in de behoeften van familieleden die al in het ziekenhuis waren opgenomen voor opname op de intensive care en die van buiten het ziekenhuis op de intensive care opgenomen worden

7. Zijn er verschillen in de behoeften van familieleden van patiënten die voor de eerste keer zijn opgenomen en die meerdere keren zijn opgenomen

8. Is er verschil in behoeften van familieleden met een verschillend opleidingsniveau

9. Zijn er verschillen in de behoeften van familieleden tussen de verschillende behoeftencategorieën

10. Hoe verloopt de samenwerking tussen de verschillende disciplines met betrekking tot familiebegeleiding

11. Hoe zien de intensive care verpleegkundigen de samenwerking met andere disciplines ten aanzien van de familiebegeleiding (overname van taken etc.)

12. Wordt de intensive care verpleegkundige gekoppeld aan een bepaalde patiënt

13. Wordt de familie in de zorg voor de patiënt betrokken 


\section{Bijlage 5a Interview gastgezinnen}

1. Sinds wanneer bent u gestart als gastgezin

2. Wat was de reden dat u zich opgaf als gastgezin

3. Zijn er voorwaarden aan verbonden om als gastgezin op te treden

4. Hoe worden de familieleden in het gezin opgevangen Wordt er veel besproken of is het alleen een overnachtingsmogelijkheid

5. Welke onderwerpen met betrekking tot de behoeften van familieleden komen ter sprake

6. Krijgt u ook informatie van de familieleden over de opvang in het ziekenhuis

7. Kunt u de opvang altijd aan

8. Is het een belasting voor uw gezin om als gastgezin op te treden Kunt $\mathrm{u}$ over deze zaken praten met andere gastgezinnen en/of gastvrouwen van het ziekenhuis

9. Hoeveel familieleden ontvangt u per maand

10. Heeft u geregeld contact met het ziekenhuis

11. Heeft $u$ regelmatig contact met andere gastgezinnen en/of gastvrouwen

12. Komen er bij u ook familieleden van patiënten die met spoed zijn opgenomen Zo ja, is er verschil in behoeften van familieleden van patiěnten die met spoed zijn opgenomen en die een geplande opname ondergingen

13. Krijgt $\mathrm{u}$ familieleden met een verschillend opleidingsniveau en zijn er verschillen in behoeften 


\section{Bijlage 5b Interview hoofd gastvrouwen}

1. Hoeveel gastvrouwen zijn er

2. Wat houdt de taak van een gastvrouw in en is deze taak specifiek gericht op de familiebegeleiding op de intensive care

3. Waarom is de functie van gastvrouw ontstaan

4. Wat zijn de voorwaarden om gastvrouw te worden (opleiding of cursus)

5. Welke behoeften worden gesignaleerd bij familieleden van intensive care patiênten

6. Zijn er verschillen in de behoeften van familieleden die al in het ziekenhuis waren opgenomen voor opname op de intensive care en die van buiten het ziekenhuis op de intensive care opgenomen worden

7. Zijn er verschillen in de behoeften van familieleden van patiënten die voor de eerste keer zijn opgenomen en die meerdere keren zijn opgenomen

8. Is er verschil in behoeften van familieleden met een verschillend opleidingsniveau

9. Is er sprake van samenwerking met andere disciplines zoals artsen, verpleegkundigen, etc. Vindt er overleg plaats met de samenwerkende disciplines

10. Zijn er grenzen aan de verantwoordelijkheden van de gastvrouwen

Mag een gastvrouw informatie verstrekken met betrekking tot de diagnose van de patiënt

11. Hoeveel uur per dag is de gastvrouw aanwezig

Wie neemt de taak van de gastvrouw over bij afwezigheid

12. Hoe wordt het systeem van de gastgezinnen geregeld

Is dit voortgekomen uit behoeften van familieleden

Is er sprake van tekortschieten van het ziekenhuis en afschuiven van bepaalde taken 


\section{Bijlage 6 Casus pilotstudy (Kaljouw, 1990)}

U geniet nu twee jaar, samen met uw partner, van uw pensioen en $u$ hebt beiden een druk sociaal leven. Tijdens een concert, 30 kilometer van uw woonplaats, krijgt uw partner hevige pijn in de buikstreek, braakt en dreigt flauw te vallen.

In paniek roept $u$ om hulp. Onmiddellijk bieden zich hulpverleners aan en wordt een ambulance gebeld die binnen 10 minuten ter plaatse is. Uw partner ziet wit, voelt klam en toont geen enkele reactie meer.

Snel wordt hij/zij per ambulance naar het dichtsbijzijnde ziekenhuis vervoerd. U rijdt mee in de ambulance.

Bij binnenkomst op de spoedeisende hulp wordt u gevraagd te wachten terwijl uw partner onderzocht wordt. Na een half uur komt de arts naar $u$ toe die u vertelt dat uw partner geopereerd wordt en dat u mag wachten naast de intensive care afdeling waar uw partner, na de operatie, opgenomen zal worden. Er dreigt levensgevaar zegt de arts.

Vier uur later mag $u$, op de intensive care, naar uw partner komen kijken. $U$ treft chaos, uw partner ligt aan een beademingsmachine en overal zitten slangen en lijnen aangesloten.

U herkent uw partner nauwelijks. 


\section{Bijlage 7 24-itemlijst (Kaljouw, 1991)}

\section{Vindt $u$ het belangrijk dat:}

u op de hoogte gesteld wordt van de gevolgen van de aandoening verantwoord het ziekenhuis kunt verlaten op de hoogte gesteld wordt van een eventuele overplaatsing uitgelegd wordt hoe de apparatuur, die gebruikt wordt, werkt $\mathrm{u}$ uitleg krijgt over de medische behandeling u geïnformeerd wordt als de situatie verslechterd er een contactpersoon is $\mathrm{u}$ iedere dag met dezelfde verpleegkundige kunt spreken een keer per dag informatie krijgt er een vast tijdstip is voor het stellen van vragen $u$ ieder gewenst moment kunt informeren uw vragen eerlijk beantwoord worden er iemand aanwezig is bij het eerste bezoek aan de patiënt u ondersteuning krijgt van een pastoraal medewerker ondersteuning krijgt van een intensive care medewerker u met andere familieleden op de intensive care in contact kunt treden u kunt spreken over ervaringen en gevoelens $u$ het gevoel heeft niet in de weg te lopen $u$ direct na opname op bezoek kunt u voortdurend aanwezig kunt zijn $\mathrm{u}$ op ieder gewenst moment op bezoek kunt bezoekuren op tijd beginnen er overnachtingsmogelijkheden geboden worden u gebruik kunt maken van koffie en thee 
Bijlage 8 Correlatiematrices 


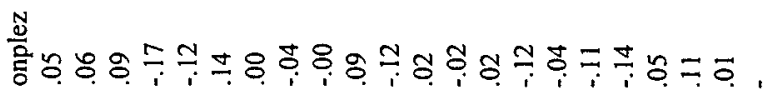

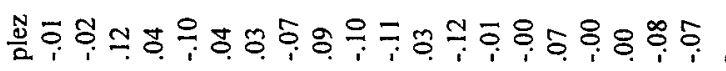

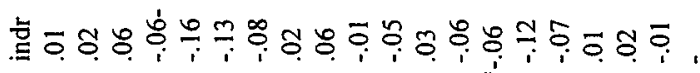

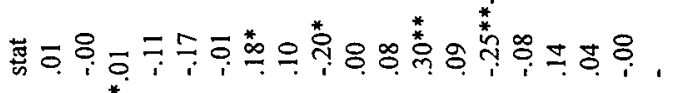

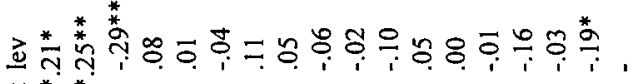

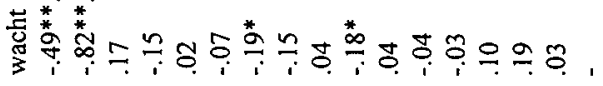

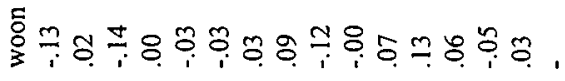

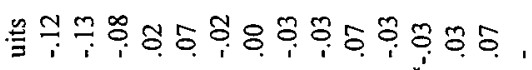

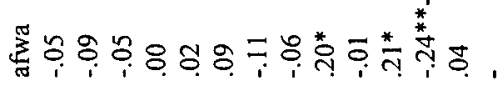

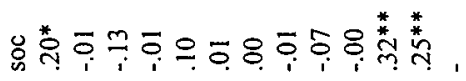

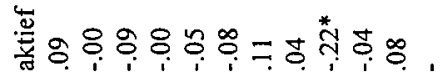

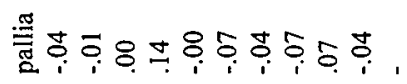

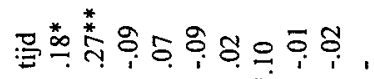

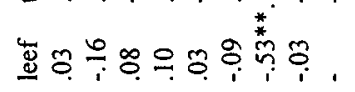

흔

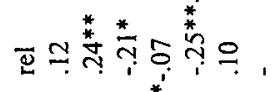

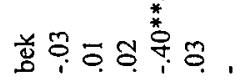

ङ

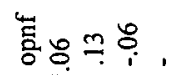

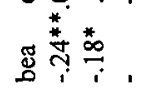

急荌

言,

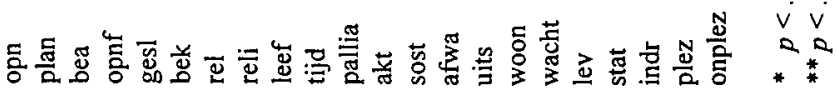


Correlatiematrix afhankelijke- en overige factoren /onafhankelijke factoren (totale groep)

Informatie Ondersteuning Toegankelijkheid Begeleiding

$\begin{array}{lllll}\text { opn } & -.00 & -.06 & -.07 & -.06 \\ \text { plan } & .11 & -.06 & -.04 & -.00 \\ \text { bea } & -.08 & -.14 & -.06 & -.13 \\ \text { opnf } & .18^{*} & .15 & .16 & .22^{*} \\ \text { gesl } & .16 & .16 & .20^{*} & .23^{* *} \\ \text { bek } & -.00 & -.11 & -.10 & -.10 \\ \text { rel } & .01 & -.04 & -.16 & -.07 \\ \text { reli } & -.12 & -.22^{*} & -.14 & -.15 \\ \text { leef } & -.13 & .01 & .12 & -.00 \\ \text { tijd } & -.15 & .04 & .04 & .02 \\ \text { pallia } & .15 & .14 & .06 & .17 \\ \text { aktief } & .14 & -.06 & .02 & .03 \\ \text { sost } & .27^{* *} & .28^{* *} & .14 & .32^{* *} \\ \text { afwa } & -.07 & .12 & .08 & .09 \\ \text { uits } & .10 & .02 & .24^{* *} & .14 \\ \text { woon } & .03 & .09 & .02 & .07 \\ \text { wacht } & -.08 & .09 & .02 & .02 \\ \text { lev } & .08 & .11 & -.04 & .08 \\ \text { stat } & -.05 & -.13 & -.11 & -.14 \\ \text { onplez } & -.12 & -.09 & -.37^{* *} & -.25^{* *}\end{array}$

$* p<.01$ (tweezijdig gemeten)

${ }^{* *} p<.001$ (tweezijdig gemeten)

Lijst van gebruikte afkortingen en wijze van scoren

\begin{tabular}{|c|c|c|c|c|c|}
\hline \multicolumn{2}{|c|}{ Lijst van gebruikte afkortingen } & \multicolumn{4}{|c|}{ Wijze van scoren } \\
\hline & & 1 & 2 & 3 & 4 \\
\hline $\begin{array}{l}\text { opn } \\
\text { plan } \\
\text { bea } \\
\text { opnf } \\
\text { gesl } \\
\text { bek } \\
\text { rel } \\
\text { reli } \\
\text { leef } \\
\text { tijd } \\
\text { pallia } \\
\text { actief } \\
\text { sost } \\
\text { afwa } \\
\text { uits } \\
\text { woon } \\
\text { wacht } \\
\text { lev } \\
\text { stat } \\
\text { onplez }\end{array}$ & $\begin{array}{l}\text { opname-indicatie van de patient } \\
\text { planning van de opname } \\
\text { mechanische beademing } \\
\text { eerste opname } \\
\text { geslacht } \\
\text { bekendheid met de intensive care } \\
\text { relatie met de patient } \\
\text { geloof } \\
\text { leeftijd } \\
\text { tijdstip van afname vragenlijst } \\
\text { palliatief gedrag } \\
\text { actief aanpakken } \\
\text { afwachten en vermijden } \\
\text { uitstel van de opname } \\
\text { woongebied } \\
\text { wachttijd op opname } \\
\text { inschatting levensbedreiging van de pati- } \\
\text { ent } \\
\text { status } \\
\text { onplezierige ervaring }\end{array}$ & $\begin{array}{l}\text { hart } \\
\text { ja } \\
\text { ja } \\
\text { ja } \\
\text { man } \\
\text { ja } \\
\text { partner } \\
\text { ja } \\
20-40 \\
1-24 \\
\text { nooit } \\
\text { nooit } \\
\text { nooit } \\
\text { nooit } \\
\text { nee } \\
\text { Utrecht } \\
\text { nee } \\
\text { niet } \\
\text { laag } \\
\text { ja }\end{array}$ & $\begin{array}{l}\text { overig } \\
\text { nee } \\
\text { nee } \\
\text { nee } \\
\text { vrouw } \\
\text { nee } \\
\text { anders } \\
\text { nee } \\
41-60 \\
25-48 \\
\text { soms } \\
\text { soms } \\
\text { soms } \\
\text { soms } \\
\text { ja } \\
\text { Geld/Over } \\
\text { ja } \\
\text { levensbedr } \\
\text { midden. } \\
\text { nee }\end{array}$ & $\begin{array}{l}>60 \\
49.72 \\
\text { vaak } \\
\text { vaak } \\
\text { vaak } \\
\text { vaak } \\
\text { rest Ned. } \\
\text { zeer } \\
\text { hoog }\end{array}$ & $\begin{array}{l}\text { zeer vaak } \\
\text { zeer vaak } \\
\text { zeer vaak } \\
\text { zeer vaak }\end{array}$ \\
\hline
\end{tabular}




\section{Correlatiematrix afhankelijke- en overige factoren /onafhankelijke factoren (harten)}

\section{Informatie Ondersteuning Toegankelijkheid Begeleiding}

$\begin{array}{lllll}\text { plan } & .10 & .09 & .02 & .10 \\ \text { bea } & -.16 & .01 & -.11 & -.10 \\ \text { opnf } & .20 & .18 & .20 & .28^{*} \\ \text { gesl } & .30^{*} & .18 & .26 & .32^{*} \\ \text { bek } & -.04 & -.15 & -.22 & -.18 \\ \text { rel } & .01 & -.09 & -.15 & -.10 \\ \text { reli } & .01 & -.13 & .07 & -.04 \\ \text { leef } & -.21 & -.02 & .11 & -.06 \\ \text { tijd } & .11 & .00 & .12 & .09 \\ \text { pallia } & .23 & .22 & .07 & .25 \\ \text { aktief } & .15 & -.14 & .04 & .00 \\ \text { sost } & .24 & .29 * & .11 & .30 * \\ \text { afwa } & -.01 & .08 & -.02 & .03 \\ \text { uits } & .23 & -.00 & .30^{*} & .21 \\ \text { woon } & .01 & -.03 & .00 & -.01 \\ \text { wacht } & .04 & -.00 & -.02 & .00 \\ \text { lev } & .03 & -.00 & -.15 & -.04 \\ \text { stat } & -.05 & -.08 & -.02 & -.07 \\ \text { onplez } & -.07 & -.12 & -.37^{* *} & -.24 \\ & & & & \\ * \quad p<.01 \text { (tweezijdig gemeten) } & & \\ * * p<.001 \text { (tweezijdig gemeten) } & & \end{array}$

Lijst van gebruikte afkortingen en wijze van scoren

\begin{tabular}{|c|c|c|c|c|c|}
\hline \multicolumn{2}{|c|}{ Lijst van gebruikte afkortingen } & \multicolumn{4}{|c|}{ Wijze van scoren } \\
\hline & & 1 & 2 & 3 & 4 \\
\hline $\begin{array}{l}\text { opn } \\
\text { plan } \\
\text { bea } \\
\text { opnf } \\
\text { gesl } \\
\text { bek } \\
\text { rel } \\
\text { reli } \\
\text { leef } \\
\text { tijd } \\
\text { pallia } \\
\text { actief } \\
\text { sost } \\
\text { afwa } \\
\text { uits } \\
\text { woon } \\
\text { wacht } \\
\text { lev } \\
\text { stat } \\
\text { onplez }\end{array}$ & $\begin{array}{l}\text { opname-indicatie van de patient } \\
\text { planning van de opname } \\
\text { mechanische beademing } \\
\text { cerste opname } \\
\text { geslacht } \\
\text { bekendheid met de intensive care } \\
\text { relatie met de patient } \\
\text { geloof } \\
\text { leeftijd } \\
\text { tijdstip van afname vrageniijst } \\
\text { palliatief gedrag } \\
\text { actief aanpakken } \\
\quad \text { sociale steun zoeken } \\
\text { afwachten en vermijden } \\
\text { uitstel van de opname } \\
\text { woongebied } \\
\text { wachttijd op opname } \\
\text { inschatting levensbedreiging van de pati- } \\
\text { ent } \\
\text { status } \\
\text { onplezierige ervaring }\end{array}$ & $\begin{array}{l}\text { hart } \\
\text { ja } \\
\text { ja } \\
\text { ja } \\
\text { man } \\
\text { ja } \\
\text { partner } \\
\text { ja } \\
20-40 \\
1-24 \\
\text { nooit } \\
\text { nooit } \\
\text { nooit } \\
\text { nooit } \\
\text { nee } \\
\text { Utrecht } \\
\text { nee } \\
\text { niet } \\
\text { laag } \\
\text { ja }\end{array}$ & $\begin{array}{l}\text { overig } \\
\text { nee } \\
\text { nee } \\
\text { nee } \\
\text { vrouw } \\
\text { nee } \\
\text { anders } \\
\text { nee } \\
41-60 \\
25-48 \\
\text { soms } \\
\text { soms } \\
\text { soms } \\
\text { soms } \\
\text { ja } \\
\text { Geld/Over } \\
\text { ja } \\
\text { levensbedr } \\
\text { midden } \\
\text { nee }\end{array}$ & $\begin{array}{l}>60 \\
49-72 \\
\text { vaak } \\
\text { vaak } \\
\text { vaak } \\
\text { vaak } \\
\text { rest Ned. } \\
\text { zeer } \\
\text { hoog }\end{array}$ & $\begin{array}{l}\text { zeer vaak } \\
\text { zeer vaak } \\
\text { zeer vaak } \\
\text { zeer vaak }\end{array}$ \\
\hline
\end{tabular}




\section{Informatie Ondersteuning Toegankelijkheid Begeleiding}

$\begin{array}{lllll}\text { plan } & .15 & -.12 & -.03 & -.01 \\ \text { bea } & -.03 & -.29 * & -.05 & -.20 \\ \text { opnf } & .17 & .13 & .10 & .19 \\ \text { gesl } & .04 & .14 & .16 & .16 \\ \text { bek } & .02 & -.08 & -.00 & -.03 \\ \text { rel } & .02 & .01 & -.15 & -.04 \\ \text { reli } & -.05 & -.28^{*} & -.12 & -.22 \\ \text { leef } & -.07 & .05 & .13 & .05 \\ \text { tijd } & -.17 & .09 & .01 & -.01 \\ \text { pallia } & .09 & .07 & .05 & .10 \\ \text { aktief } & .13 & .02 & .02 & .07 \\ \text { sost } & .31^{*} & .31^{*} & .19 & .38^{* *} \\ \text { afwa } & .00 & .14 & .17 & .15 \\ \text { uits } & -.04 & .04 & .15 & .06 \\ \text { woon } & .04 & .18 & .02 & .121 \\ \text { wacht } & -.20 & .13 & -.00 & -.01 \\ \text { lev } & .12 & .23 & .06 & .21 \\ \text { stat } & -.05 & -.17 & -.19 & -.19 \\ \text { onplez } & -.18 & -.06 & -.37^{* *} & -.25 * \\ & & & & \\ * \quad p<.01 \text { (tweezijdig gemeten) } & & \\ * * p<.001 \text { (tweezijdig gemeten) } & & \end{array}$

Lijst van gebruikte afkortingen en wijze van scoren

\begin{tabular}{|c|c|c|c|c|c|}
\hline \multicolumn{2}{|c|}{ Lijst van gebruikte afkortingen } & \multicolumn{4}{|c|}{ Wijze van scoren } \\
\hline & & 1 & 2 & 3 & 4 \\
\hline $\begin{array}{l}\text { opn } \\
\text { plan } \\
\text { bea } \\
\text { opnf } \\
\text { gesl } \\
\text { bek } \\
\text { rel } \\
\text { reli } \\
\text { leef } \\
\text { tijd } \\
\text { pallia } \\
\text { actief } \\
\text { sost } \\
\text { afwa } \\
\text { uits } \\
\text { woon } \\
\text { wacht } \\
\text { lev } \\
\text { stat } \\
\text { onplez }\end{array}$ & $\begin{array}{l}\quad \text { opname-indicatie van de patient } \\
\text { planning van de opname } \\
\text { mechanische beademing } \\
\text { eerste opname } \\
\text { geslacht } \\
\text { bekendheid met de intensive care } \\
\text { relatie met de patiënt } \\
\text { geloof } \\
\text { leeftijd } \\
\text { tijdstip van afname vragenlijst } \\
\text { palliatief gedrag } \\
\text { actief aanpakken } \\
\quad \text { sociale steun zoeken } \\
\text { afwachten en vermijden } \\
\text { uitstel van de opname } \\
\text { woongebied } \\
\text { wachttijd op opname } \\
\text { inschatting levensbedreiging van de pati- } \\
\text { ent } \\
\text { status } \\
\text { onplezierige ervaring }\end{array}$ & $\begin{array}{l}\text { hart } \\
\text { ja } \\
\text { ja } \\
\text { ja } \\
\text { man } \\
\text { ja } \\
\text { partner } \\
\text { ja } \\
20-40 \\
1-24 \\
\text { nooit } \\
\text { nooit } \\
\text { nooit } \\
\text { nooit } \\
\text { nee } \\
\text { Utrecht } \\
\text { nee } \\
\text { niet } \\
\text { laag } \\
\text { ja }\end{array}$ & $\begin{array}{l}\text { overig } \\
\text { nee } \\
\text { nee } \\
\text { nee } \\
\text { vrouw } \\
\text { nee } \\
\text { anders } \\
\text { nee } \\
41-60 \\
25-48 \\
\text { soms } \\
\text { soms } \\
\text { soms } \\
\text { soms } \\
\text { ja } \\
\text { Geld/Over } \\
\text { ja } \\
\text { levensbedr } \\
\text { midden } \\
\text { nee }\end{array}$ & $\begin{array}{l}>60 \\
49-72 \\
\text { vaak } \\
\text { vaak } \\
\text { vaak } \\
\text { vaak } \\
\text { rest Ned. } \\
\text { zeer } \\
\text { hoog }\end{array}$ & $\begin{array}{c}\text { zeer vaak } \\
\text { zeer vaak } \\
\text { zeer vaak } \\
\text { zeer vaak }\end{array}$ \\
\hline
\end{tabular}





\section{Bijlage 9}

\section{C.C.F.N.I.N.(ederland)}

\section{Patiëntgegevens}

(patiëntengegevens af te leiden van het ponsplaatje worden deze studie verder niet gebruikt)

\section{Ponsplaatje}

1 Opname-indicatie patiënt

2 Gepland

3 Wachttijd

4 Is de opname uitgesteld?

5 Mechanische beademing

6 Eerste opname

7 Tijdstip van afname vragenlijst
Hartoperatiepatiënt

Overige intensive care patiënt $\square$

ㅁ

ja

nee

ja $\square$

nee $\square$

ja $\square$

nee $\quad \mathrm{C}$

ja $\square$

nee $\square$

ja $\quad \square$

nee

1 - 24 uur

$25-48$ uur 口

49 - 72 uur $\square$

8 Hoe ervaart u de mate van levensbedreiging van uw familielid? (cijfer tussen de 1 , geen levensbedreiging, en de 10 , zeer levensbedreigend) 


\section{In te vullen door de verpleegkundige}

9 Hoe ervaart $u$ de mate van levensbedreiging van de patiënt? (cijfer tussen de 1, geen levensbedreiging, en de 10, zeer levensbedreigend)

\section{Algemene vragen}

10 Geslacht

11 Leeftijd

12 Relatie tot de patiënt

13 Bent u gelovig?

14 In welke provincie woont $u$ ?

15 Wat is uw beroep?

16 Wat is uw hoogst genoten opleiding?

17 Bent $u$ bekend met een intensive care?

18 Heeft u een onplezierige ervaring meegemaakt op de intensive care? man

$\square$

vrouw

$\square$

............

partner

口

anders

ja

nee

Groningen

Friesland

Drenthe

Overijssel

Gelderland

Utrecht

Noord-Brabant

Limburg

Zeeland

Noord-Holland

Zuid-Holland

Flevoland nee $\square$

ja $\square$

nee $\square$ 


\section{Behoeftenlijst}

\section{Behoeften ten aanzien van informatie}

1a Vindt $\mathrm{u}$ het belangrijk dat $\mathrm{u}$ verteld wordt wat de eventuele gevolgen van de aandoening/opname voor uw familielid zijn?

1b Door wie vindt $u$ dat dit verteld moet worden?

1c Is $u$ verteld wat de eventuele gevolgen zijn?

1d Zo ja, door wie is u dit verteld?

2a Vindt $u$ het belangrijk dat, wanneer $u$ het ziekenhuis verlaat, dit verantwoord is gezien de algehele toestand van uw familielid?

2b Was het verantwoord om het ziekenhuis te verlaten?

3a Vindt $u$ het belangrijk tijdig op de hoogte gesteld te worden van eventuele overplaatsing van uw familielid naar een ander ziekenhuis/ afdeling?

3b Door wie wilt u op de hoogte worden gesteld?

3c Bent u tijdig op de hoogte gesteld?
1

2

3

4

1

2

3

4

5

1

2

1

$$
\begin{array}{ll}
\square & \text { onbelangrijk } \\
\square & \text { niet zo belangrijk } \\
\square & \text { belangrijk } \\
\square & \text { zeer belangrijk }
\end{array}
$$

$\begin{array}{ll}\square & \text { arts } \\ \square & \text { verpleegkundige } \\ \square & \text { gastvrouw } \\ \square & \text { anders, n.l. } \\ \square & \text { niemand } \\ & \\ \square & \text { ja } \\ \square & \text { nee } \\ & \\ \square & \text { arts } \\ \square & \text { verpleegkundige } \\ \square & \text { gastvrouw } \\ \square & \text { anders, n.l. } \\ \square & \text { niemand }\end{array}$

\section{a onbelangrijk \\ ㅁ niet zo belangrijk \\ $\square$ belangrijk \\ $\square \quad$ zeer belangrijk}

$$
\begin{array}{ll}
\square & \text { ja } \\
\square & \text { nee } \\
\square & \text { weet niet } \\
\square & \text { n.v.t. }
\end{array}
$$
ㅁ onbelangrijk
ㅁ niet zo belangrijk
ㅁ belangrijk
ㅁ zeer belangrijk

$\begin{array}{ll}\square & \text { arts } \\ \square & \text { verpleegkundige } \\ \square & \text { gastvrouw } \\ \square & \text { anders, n.l. } \\ \square & \text { niemand }\end{array}$

$\begin{array}{ll}\square & \text { ja } \\ \square & \text { nee } \\ \square & \text { n.v.t. }\end{array}$


3d Zo ja, door wie bent u op de hoogte gesteld?

4a Vindt $u$ het belangrijk dat iemand $u$ vertelt hoe de apparatuur, die bij uw familielid gebruikt wordt, werkt?

4b Door wie vindt $u$ dat dit uitgelegd moet worden?

4c Is er uitleg gegeven over de apparatuur die bij uw familielid wordt gebruikt?

4d Zo ja, door wie is de uitleg gegeven?

5a Vindt $\mathrm{u}$ het belangrijk te weten welke medische behandeling uw familielid krijgt op de intensive care?

5b Door wie vindt $u$ dat dit verteld moet worden?

5c Is u verteld welke behandeling uw familielid krijgt op de intensive care?

5d Zo ja, door wie is u dit verteld?

6a Vindt $u$ het belangrijk dat $u$ thuis opgebeld wordt als de situatie van uw familielid verslechterd?
$1 \quad \square \quad$ arts

$2 \square$ verpleegkundige

$3 \quad$ gastrrouw

$4 \quad \square \quad$ anders, n.l.

$5 \square$ niemand

$1 \quad \square \quad$ onbelangrijk

$2 \quad \square \quad$ niet zo belangrijk

$3 \quad \square \quad$ belangrijk

$4 \quad \square \quad$ zeer belangrijk

$1 \quad \square \quad$ arts

2 verpleegkundige

$3 \square$ gastvrouw

$4 \square$ anders, n.l.

5 niemand

$1 \quad \square \quad$ ja

$2 \square$ nee

$1 \quad \square \quad$ arts

$2 \square$ verpleegkundige

$3 \square$ gastvrouw

$4 \square$ anders, n.l.

5 ㅁ niemand

$\square \quad$ onbelangrijk

$2 \quad \square \quad$ niet zo belangrijk

$3 \square$ belangrijk

$4 \quad \square \quad$ zeer belangrijk

$1 \quad \square \quad$ arts

$2 \square$ verpleegkundige

$3 \quad$ gastvrouw

$4 \quad \square \quad$ anders, n.l.

$1 \quad \mathrm{ja}$

$2 \square$ nee

$1 \quad \square \quad$ arts

$2 \square$ verpleegkundige

$3 \square$ gastvrouw

$4 \square$ anders, n.l.

$\square \quad$ onbelangrijk

$2 \square$ niet zo belangrijk

$3 \square$ belangrijk

$4 \quad \square \quad$ zeer belangrijk 
6b Door wie vindt $u$ dat $u$ opgebeld moet worden?

6c Bent u opgebeld toen de situatie van uw familielid verslechterde?

6d Zo ja, door wie bent u opgebeld?

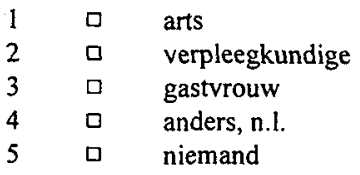

7 Hoe tevreden bent u over de informatie? (geef een rapportcijfer tussen de 1 en de 10)

\section{Behoeften ten aanzien van communicatie}

8a Vindt $u$ het belangrijk dat er een contactpersoon is tussen de intensive care en $u$ ?

$8 \mathrm{~b}$ Wie vindt u dat de contactpersoon zou moeten zijn?

8c Is er een contactpersoon tussen de intensive care en $\mathrm{u}$ ?

8d Zo ja wie is dat?

9a Vindt $u$ het belangrijk iedere dag dezelfde verpleegkundige te kunnen spreken?

9b Kunt $u$ iedere dag met dezelfde verpleegkundige spreken? a arts

$2 \quad \square \quad$ verpleegkundige

$3 \square$ gastvrouw

$4 \square$ anders, n.l.

$5 \square$ niemand

$\begin{array}{lll}1 & \square & \text { onbelangrijk } \\ 2 & \square & \text { niet zo belangrijk } \\ 3 & \square & \text { belangrijk } \\ 4 & \square & \text { zeer belangrijk } \\ & & \\ 1 & \square & \text { arts } \\ 2 & \square & \text { verpleegkundige } \\ 3 & \square & \text { gastvrouw } \\ 4 & \square & \text { anders, n.l. } \\ 5 & \square & \text { niemand }\end{array}$

$\begin{array}{lll}1 & \square & \text { ja } \\ 2 & \square & \text { nee }\end{array}$

$2 \square \quad$ verpleegkundige

$3 \square$ gastvrouw

$4 \quad \square \quad$ anders, n.l.

1 ㅁ onbelangrijk

$2 \quad \square \quad$ niet zo belangrijk

$3 \square$ belangrijk

$4 \quad \square \quad$ zeer belangrijk

$1 \quad \square \quad$ ja

$2 \square$ nee
$1 \quad \square \quad$ arts 
10a Vindt $u$ het belangrijk om tenminste eenmaal per dag informatie over uw familielid te ontvangen?

10b Van wie wilt u informatie ontvangen?

10c Ontvangt $\mathrm{u}$ tenminste eenmaal per dag informatie over uw familielid?

10d Zo ja, van wie heeft $u$ deze informatie ontvangen?

$11 \mathrm{a}$ Vindt $u$ het belangrijk dat er op een vast tijdstip de gelegenheid geboden wordt om vragen te stellen?

11b Aan wie zou dan vragen willen stellen?

12a Vindt $u$ het belangrijk dat $u$ op ieder moment kan informeren naar de toestand van uw familielid?

12b Van wie zou u de informatie willen ontvangen?

13a Vindt $u$ het belangrijk dat uw vragen eerlijk beantwoord worden?

13b Heeft $u$ het gevoel dat uw vragen eerlijk beantwoord zijn?

$1 \quad \square \quad$ ja

$2 \square$ nee

14 Hoe tevreden bent u over de communicatie? (geef een rapportcijfer tussen de 1 en de 10 ) 


\section{Behoeften ten aanzien van ondersteuning}

15a Vindt $u$ het belangrijk dat er iemand bij $u$ is wanneer $u$ voor het eerst uw familielid op op de intensive care bezoekt?

15b Wie zou er bij u moeten zijn buiten uw familie, vrienden?

$\begin{array}{lll}1 & \square & \text { onbelangrijk } \\ 2 & \square & \text { niet zo belangrijk } \\ 3 & \square & \text { belangrijk } \\ 4 & \square & \text { zeer belangrijk } \\ & & \\ 1 & \square & \text { arts } \\ 2 & \square & \text { verpleegkundige } \\ 3 & \square & \text { gastvrouw } \\ 4 & \square & \text { anders, n.l. } \\ 5 & \square & \text { niemand } \\ & & \\ 1 & \square & \text { ja } \\ 2 & \square & \text { nee } \\ & & \\ 1 & \square & \text { arts } \\ 2 & \square & \text { verpleegkundige } \\ 3 & \square & \text { gastvrouw } \\ 4 & \square & \text { anders, n.l. }\end{array}$

15c Was er iemand bij $\mathrm{u}$ toen $\mathrm{u} u \mathrm{u}$ familielid voor de eerste keer bezocht?

15d Zo ja, wie was er bij u buiten uw familie, vrienden? anders, n.l.

16a Vindt $\mathrm{u}$ het belangrijk dat $\mathrm{u}$ ondersteuning krijgt van een pastoraal werker uit het ziekenhuis?

16b Heeft $u$ ondersteuning van een pastoraal werker van het ziekenhuis gekregen?

17a Vindt $u$ het belangrijk dat iemand $u$ op de intensive care ondersteunt buiten uw familie, vrienden?

17b Van wie zou u de ondersteuning willen ontvangen buiten familie en vrienden?

17c Was er iemand die $u$ op de intensive care ondersteunde buiten familie en vrienden?

17d Zo ja, wie ondersteunde $u$ op de intensive care buiten familie en vrienden?

18a Vindt $u$ het belangrijk om met mensen die ook een familielid op de intensive care bezoeken in contact te treden?

$\begin{array}{lll}1 & \square & \text { onbelangrijk } \\ 2 & \square & \text { niet zo belangrijk } \\ 3 & \square & \text { belangrijk } \\ 4 & \square & \text { zeer belangrijk } \\ 1 & \square & \text { ja } \\ 2 & \square & \text { nee } \\ 1 & \square & \text { onbelangrijk } \\ 2 & \square & \text { niet zo belangrijk } \\ 3 & \square & \text { belangrijk } \\ 4 & \square & \text { zeer belangrijk } \\ & & \\ 1 & \square & \text { arts } \\ 2 & \square & \text { verpleegkundige } \\ 3 & \square & \text { gastvrouw } \\ 4 & \square & \text { anders, n.l. } \\ 5 & \square & \text { niemand } \\ & & \\ 1 & \square & \text { ja } \\ 2 & \square & \text { nee } \\ 1 & \square & \text { arts } \\ 2 & \square & \text { verpleegkundige } \\ 3 & \square & \text { gastvrouw } \\ 4 & \square & \text { anders, n.l. } \\ & & \\ 1 & \square & \text { onbelangrijk } \\ 2 & \square & \text { niet zo belangrijk } \\ 3 & \square & \text { belangrijk } \\ 4 & \square & \text { zeer belangrijk }\end{array}$


18b Bent $u$ met andere familieleden in contact getreden?

19a Vindt $u$ het belangrijk om met iemand op de intensive care over uw ervaringen en gevoelens m.b.t. de opname van uw familielid te kunnen spreken buiten familie en vrienden?

19b Met wie zou u over uw ervaringen en gevoelens willen spreken buiten familie en vrienden?

19c Heeft $u$ met iemand over uw ervaringen en gevoelens gesproken buiten familie en vrienden?

19d Zo ja, met wie heeft u over uw ervaringen en gevoelens gesproken buiten familie en vrienden?

20a Vindt $u$ het belangrijk dat $u$ het gevoel heeft dat $u$ niet in de weg loopt op de intensive care?

20b Had $u$ het gevoel dat $u$ in de weg liep op de intensive care?

21 Hoe tevreden bent $u$ over de ondersteuning? (geef een rapportcijfer tussen de 1 en de 10)

\section{Organisatorische behoeften}

22a Vindt $u$ het belangrijk om direct na de opname uw familielid op de intensive care te mogen bezoeken

23a Vindt $u$ het belangrijk dat $u$ in de gelegenheid gesteld wordt om voortdurend bij uw familielid aanwezig te zijn als $\mathrm{u}$ dat wilt?

24a Vindt $u$ het belangrijk dat $u$ de mogelijkheid krijgt uw familielid te bezoeken wanneer $u$ dat wilt?

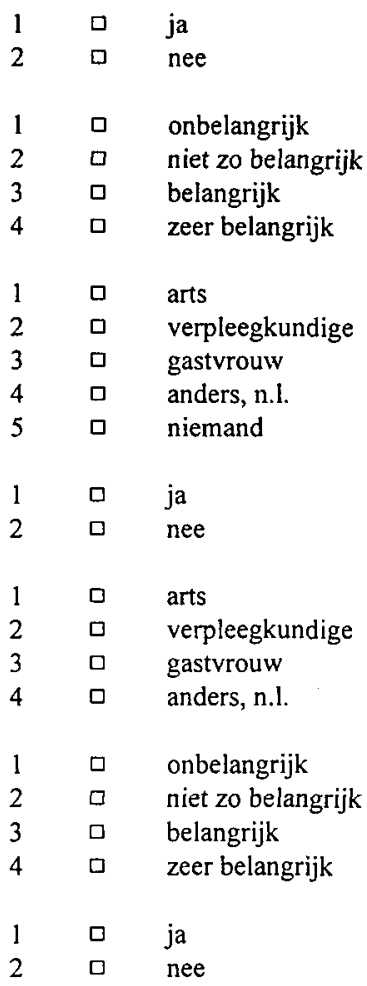


25a Vindt $\mathbf{u}$ het belangrijk dat de bezoekuren op tijd beginnen?

$\begin{array}{lll}1 & \square & \text { onbelangrijk } \\ 2 & \square & \text { niet zo belangrijk } \\ 3 & \square & \text { belangrijk } \\ 4 & \square & \text { zeer belangrijk }\end{array}$

26a Vindt u het belangrijk dat er een overnachtingsmogelijkheid wordt aangeboden in het ziekenhuis of in de directe omgeving van het ziekenhuis?

$\begin{array}{lll}1 & \square & \text { onbelangrijk } \\ 2 & \square & \text { niet zo belangrijk } \\ 3 & \square & \text { belangrijk } \\ 4 & \square & \text { zeer belangrijk } \\ & & \\ 1 & \square & \text { onbelangrijk } \\ 2 & \square & \text { niet zo belangrijk } \\ 3 & \square & \text { belangrijk } \\ 4 & \square & \text { zeer belangrijk }\end{array}$

28 Hoe tevreden bent u over de organisatie ? (geef een rapportcijfer tussen de 1 en de 10)

Heeft u nog op en aanmerkingen?

Datum :

Tijd :

Nummer : 


\section{BIJLAGE 10}

\section{Utrechtse Coping Lijst (Janssen et al., in voorbereiding)}

\section{COPING: DE WIJZE VAN OMGAAN MET PROBLEMEN}

Hieronder staan een aantal beschrijvingen van manieren, waarop men met problemen kan omgaan.Wilt $u$ bij iedere zin aangeven hoe vaak $u$ in het algemeen op de beschreven wijze reageert bij problemen. $U$ kunt dit doen door het vakje van de antwoordmogelijkheid, die het beste bij u past, aan te kruisen.

Betekenis van de vakjes:

$\begin{array}{llll}\begin{array}{l}\text { Zelden } \\ \text { of nooit }\end{array} & \text { Soms } \quad \text { Vaak } & \text { Zeer vaak }\end{array}$

1. Toegeven om moeilijke situaties

te vermijden

0

0

0

0

2. Je neerleggen bij de gang van zaken.

0

0

0

0

3. Je zorgen met iemand delen

0

0

0

0

4. Direct ingrijpen als er moeilijkheden zijn

0

0

5. Afleiding zoeken

0

0

0

6. Een probleem van alle kanten bekijken.

0

$0 \quad 0$

0

7. Moeilijke situaties zoveel mogelijk uit de weg gaan

0

0

0

8. Verschillende mogelijkheden bedenken om een probleem op te lossen.

0

0

9. Doelgericht te werk gaan .......

0

0

0

10. Iemand om hulp vragen ..........

0

0

0

11. De zaken eerst op een rij zetten

0

0

0

12. Aan andere dingen denken die niet met het probleem te maken hebben ....

0

$\begin{array}{lll}0 & 0 & 0\end{array}$

13. Je gevoelens tonen

0

0

0

0

14. Troost en begrip zoeken

0

0

0

0

15. Laten merken dat je ergens mee zit ....

0

0

0

0 



\section{DANKWOORD}

Behoeften aan begeleiding, informatie, ondersteuning en toegankelijkheid zijn, zo heb ik de afgelopen 6 jaar ondervonden, niet alleen van belang voor familieleden van intensive care patiënten. Dit boekje zou nooit tot stand zijn gekomen als er niet uitdrukkelijk in bovengenoemde voorwaarden zou zijn voorzien. Allereerst een woord van dank aan de medewerkers van de intensive care afdelingen die hun medewerking hebben verleend aan dit onderzoek. Vooral de gastvrouwen en verpleegkundigen ben ik erkentelijk voor de voortreffelijke organisatie rondom de afname van de interviews. Leo de Jong en Corine Speelman, die tijdens hun doctoraalstudie de interviews afnamen, wil ik uitdrukkelijk bedanken, niet alleen voor hun werk maar ook voor de samenwerking en de steun tijdens het veldwerk.

Prof. Dr. Van den Bergh-Braam wil ik bedanken voor het initiatief tot deze studie. Fons de Jonge wil ik bedanken voor de eerste ontmoeting die hij regelde tussen Prof. Van de Bergh en mij.

Prof. Dr. Hans Philipsen, mijn promotor, ben ik dank verschuldigd voor zijn begeleiding, geduld en de bruikbare aanwijzingen die de kwaliteit van dit proefschrift bepaald hebben. Dr. Roos Marie Bal, mijn co-promotor, wil bijzonder bedanken. Zij maakte van een "kort door de bocht" schrijver met een "in grote stappen snel thuis" methode een wetenschappelijk onderzoeker. Roos, van jou heb ik vreselijk veel geleerd en je was er altijd, of ik je nu s'avonds, in het week-end of gewoon op werkdagen nodig had. Met name in de laatste periode was je niet alleen een zeer gewenste "steunverstrekker", je hebt ook $100 \%$ gescoord. Roos, bedankt voor het vertrouwen dat je in me stelde.

De beoordelingscommissie ben ik erkentelijk voor de waardevolle suggesties die, op het laatste moment, de kwaliteit van het proefschrift ten goede kwamen.

Dini During en Mieke Noordergraaf wil ik bedanken voor hun hulp met betrekking tot alle literatuur die verzameld moest worden. Mijn collega's in het opleidingsinstituut St. Antonius Ziekenhuis ben ik dank verschuldigd voor hun nimmer aflatende steun. Frans, Joke en Karinka in het bijzonder omdat ze in de laatste periode van de tot stand koming van dit proefschrift veel werkzaamheden van me overnamen. Agneta, Olga, Marjan, Conny en Joke omdat ze de vele concepten voor me bekritiseerden. Ton omdat ze, naast de redactie, hierna vele malen de lay-out van dit proefschrift bewerkte en uiteindelijk verantwoordelijk is voor de definitieve versie.

Een bijzonder woord wil ik richten tot Marjan Kraat. Ik heb vele dieptepunten tijdens het schrijven van dit proefschrift gekend, echter éen daarvan is het noemen waard. De ongewenste publiciteit in juni 1997 was reden voor grote commotie. Door het vertrouwen dat jij in mij stelde ben ik in staat gebleken mijn proefschrift met het zelfde enthousiasme af te schrijven. Samen met een groot aantal waardevolle collega's uit de verplegingsdienst was je een schoolvoorbeeld van loyaliteit.

Bert Overkamp wil ik bedanken voor de ruimte en vrijheid die hij me gaf om, binnen mijn dienstverband met het St. Antonius Ziekenhuis, te kunnen promoveren. Het bestuur van de SOVB ben ik bijzonder erkentelijk voor de voorwaarden die zij getroffen hebben om dit boekje te kunnen drukken.

Afsluiten wil ik dit dankwoord met een vermelding van mijn "thuisfront". Mijn vrienden ben ik dank verschuldigd omdat ze, ondanks het feit dat ik ze de afgelopen jaren verwaarloosd heb, gebleven zijn. Magda, de Sambuca-avonden, soms resulterend in een "Sambuca-look" de volgende dag, zal ik nooit vergeten. Albert, Agneta, Iris en Joost wil ik bedanken voor hun belangstelling en de gezellige uitstapjes die zorgden voor de broodnodige ontspanning. En daarom Iris, is je vader mijn paranimf. Carolien, we hebben hoogte- en dieptepunten in onze vriendschap gekend. Het is me veel waard en ik ben blij dat je mijn paranimf bent. Dankbaar ben ik dat mijn ouders getuige kunnen zijn van het eindresultaat.

En dan tot slot, mijn maatje, Astrid. Jouw nimmer aflatende loyaliteit, ondersteuning en onvoorwaardelijk optimisme zijn, naast de vele werkzaamheden achter de schermen, onmisbaar geweest in deze voor mij zo belangrijke periode van mijn leven. De zolder laat ik nu voor wat hij is, de zondagen zijn weer van ons! 



\section{Curriculum Vitae}

Marian Kaljouw werd geboren op 17 juni 1956 te Bergen op Zoom. Na het behalen van het diploma tot verpleegkundige in de algemene gezondheidszorg in het Bethesda St. Joseph Ziekenhuis te Vlissingen in 1976, volgde zij de opleiding tot Coronary Care en Intensive Care Verpleegkundige binnen de Stichting Oosterschelde Ziekenhuizen, lokatie Goes. Hierna volgde zij, van 1981 tot 1983, de kaderopleiding voor intramurale gezondheidszorg aan de Hoge School Breda. Na 6 jaar werkzaam geweest zijn binnen de gecombineerde afdeling intensive care en coronary care te Goes, werd zij aangenomen in het Academisch Ziekenhuis Utrecht waar zij binnen de intensive care heelkunde 4 jaar werkzaam was in de functie van intensive care verpleegkundige. In 1987 werd zij hoofd opleidingen in het St. Antonius Ziekenhuis Nielwegein. In 1988 startte zij met de Voortgezette Opleiding Beroepsinnovatie. Na het behalen van het diploma in $1990 \mathrm{kreeg}$ zij in 1991 toestemming tot promotie aan de Universiteit Maastricht. Naast haar werkzaamheden in de functie van hoofd opleidingen was zij, van 1994 tot 1997, tevens interim-directeur van de Stichting Opleidingen Verpleegkundige Beroepen te Bunnik. In de laatste functie was zij belast met het voorzitterschap van het project Samenhangend Stelsel Midden Nederland ten behoeve van de ontwikkeling van het Samenhangend Stelsel voor Gezondheidszorgonderwijs in de regio Midden Nederland. Marian Kaljouw is voorzitter van de Nederlandse Vereniging voor Hart- en Vaatverpleegkundigen, bestuurslid van de Stichting Venticare (intensive care congresorganisatie) en lid van het Platform Verpleegkundige Tuchtcollege's dat ressorteert onder het Landelijk Centrum voor Verpleging en Verzorging te Utrecht. 